\title{
Thermal/Chemical Degradation of Ceramic Candle Filter Materials
}

\section{Final Report}

September 1988 - October 1994

January 1995

!

Work Performed Under Contract No.: DE-AC21-88MC25203

For

U.S. Department of Energy

Office of Fossil Energy

Morgantown Energy Technology Center

Morgantown, West Virginia

By

Acurex Environmental Corporation

Mountain View, California 


\section{DISCLAIMER}

This report was prepared as an account of work sponsored by an agency of the United States Government. Neither the United States Government nor any agency thereof, nor any of their employees, makes any warranty, express or implied, or assumes any legal liability or responsibility for the accuracy, completeness, or usefulness of any information, apparatus, product, or process disclosed, or represents that its use would not infringe privately owned rights. Reference herein to any specific commercial product, process, or service by trade name, trademark, manufacturer, or otherwise does not necessarily constitute or imply its endorsement, recommendation, or favoring by the United States Government or any agency thereof. The views and opinions of authors expressed herein do not necessarily state or reflect those of the United States Government or any agency thereof.

This report has been reproduced directly from the best available copy.

Available to DOE and DOE contractors from the Office of Scientific and Technical Information, 175 Oak Ridge Turnpike, Oak Ridge, TN 37831; prices available at (615) 576-8401.

Available to the public from the National Technical Information Service, U.S. Department of Commerce, 5285 Port Royal Road, Springfield, VA 22161; phone orders accepted at (703) $487-4650$. 


\title{
Thermal/Chemical Degradation of Ceramic Candle Filter Materials
}

\author{
Final Report \\ September 1988 - October 1994
}

Work Performed Under Contract No.: DE-AC21-88MC25203

\author{
For \\ U.S. Department of Energy \\ Office of Fossil Energy \\ Morgantown Energy Technology Center \\ P.O. Box 880 \\ Morgantown, West Virginia 26507-0880 \\ By
Acurex Environmental Corporation
555 Clyde Avenue
P.O. Box 7044
Mountain View, California 94039
}

January 1995 


\section{TABLE OF CONTENTS}

SECTION 1 EXECUTIVE SUMMARY $\ldots \ldots \ldots \ldots \ldots \ldots \ldots \ldots \ldots \ldots \ldots \ldots \ldots \ldots$

SECTION 2 INTRODUCTION $\ldots \ldots \ldots \ldots \ldots \ldots \ldots \ldots \ldots \ldots \ldots \ldots \ldots \ldots \ldots \ldots \ldots \ldots \ldots, 1$

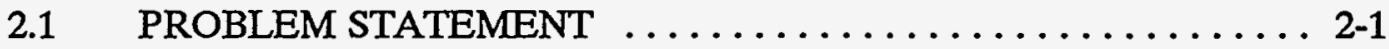

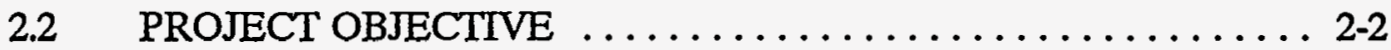

2.3 TEST SCOPE $\ldots \ldots \ldots \ldots \ldots \ldots \ldots \ldots \ldots \ldots \ldots \ldots \ldots \ldots \ldots \ldots \ldots \ldots \ldots, 2$

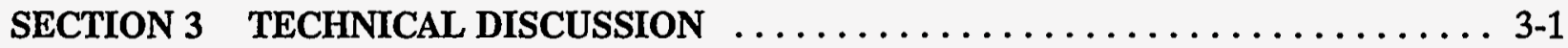

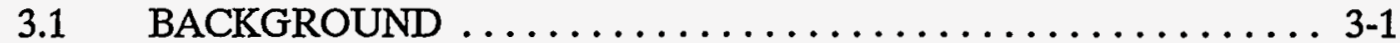

3.2 MATERIALS SELECTION $\ldots \ldots \ldots \ldots \ldots \ldots \ldots \ldots \ldots \ldots \ldots \ldots \ldots$

3.3 TEST PROCEDURES $\ldots \ldots \ldots \ldots \ldots \ldots \ldots \ldots \ldots \ldots \ldots \ldots \ldots \ldots$

3.3.1 Long-Term Thermal Exposure Tests $\ldots \ldots \ldots \ldots \ldots \ldots \ldots \ldots .4 .4$

3.3.2 C-Ring Testing $\ldots \ldots \ldots \ldots \ldots \ldots \ldots \ldots \ldots \ldots \ldots \ldots \ldots \ldots \ldots \ldots \ldots \ldots \ldots \ldots, 15$

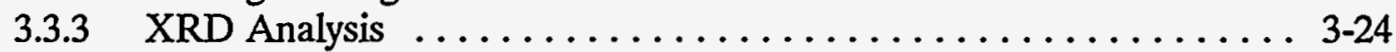

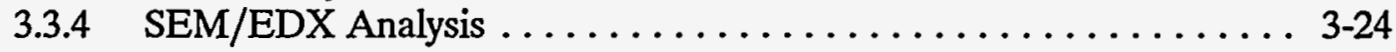

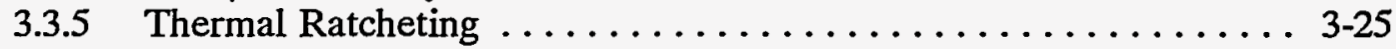

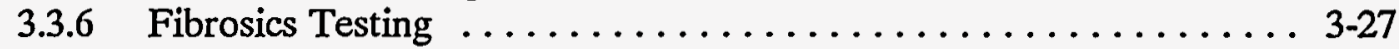

3.3.6.1 Fibrosic Candle ........................... 3-27

3.3.6.2 Fibrosic Tubesheet ......................... 3-27

SECTION 4 THERMAL/MECHANICAL TEST RESULTS AND ANALYSIS . . . . . . 4-1

4.1 C-RING TESTING $\ldots \ldots \ldots \ldots \ldots \ldots \ldots \ldots \ldots \ldots \ldots \ldots \ldots \ldots \ldots$

4.1.1 C-Ring Testing: Preliminary Investigations $\ldots \ldots \ldots \ldots \ldots \ldots 4-1$

4.1.2 C-Ring Testing: Thermal Ratcheting ............... 4-14

4.1.3 C-Ring Testing: Thermal Exposure Specimens . . . . . . . . . 4-18

4.1.4 C-Ring Testing: KRW Candle Strength $\ldots \ldots \ldots \ldots \ldots \ldots \ldots$ 4-28

4.2 SEM/EDX ANALYSIS $\ldots \ldots \ldots \ldots \ldots \ldots \ldots \ldots \ldots \ldots \ldots \ldots \ldots \ldots$

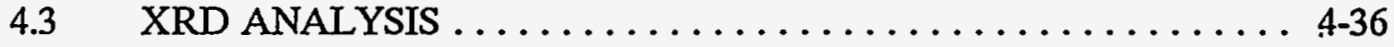

4.4 FIBROSIC TEST RESULTS . . . . . . . . . . . . . . 4-39

4.4.1 Fibrosic Candle Test Results . ................. 4-40

4.4.2 Fibrosic Tubesheet Test Results ................. 4-41

SECTION 5 CHEMICAL TEST RESULTS AND ANALYSIS $\ldots \ldots \ldots \ldots \ldots \ldots \ldots$. 1

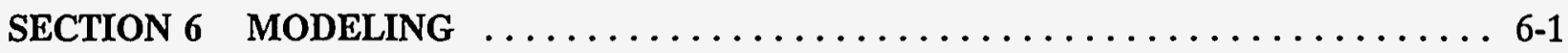

SECTION 7 CONCLUSIONS AND RECOMMENDATIONS $\ldots \ldots \ldots \ldots \ldots \ldots \ldots$. $7-1$

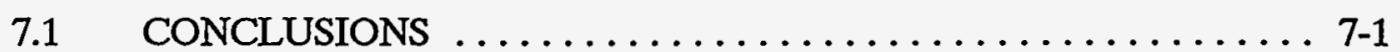

7.2 RECOMMENDATIONS $\ldots \ldots \ldots \ldots \ldots \ldots \ldots \ldots \ldots \ldots \ldots \ldots \ldots \ldots$ 
TABLE OF CONTENTS (CONCLUDED)

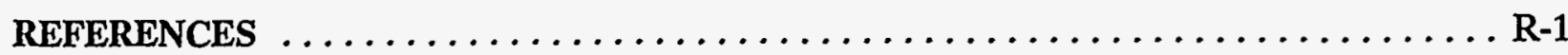

APPENDIX A - THERMAL EXPOSURE SAMPLE VESSEL DRAWINGS $\ldots \ldots \ldots \ldots$ A-1

APPENDIX B - DRAWINGS OF C-RING TESTING FIXTURES $\ldots \ldots \ldots \ldots \ldots \ldots$ B-1

N MOV \& A PPENDIX C - REPORT: "THERMAL SHOCK-INDUCED STRENGTH

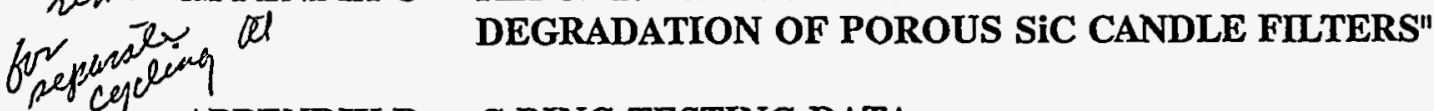

$\mathrm{C}-1$

APPENDIX D - C-RING TESTING DATA $\ldots \ldots \ldots \ldots \ldots \ldots \ldots \ldots \ldots \ldots \ldots \ldots \ldots \ldots \ldots \ldots \ldots$

APPENDIX E - X-RAY DIFFRACTION DATA $\ldots \ldots \ldots \ldots \ldots \ldots \ldots \ldots \ldots \ldots$ E-1

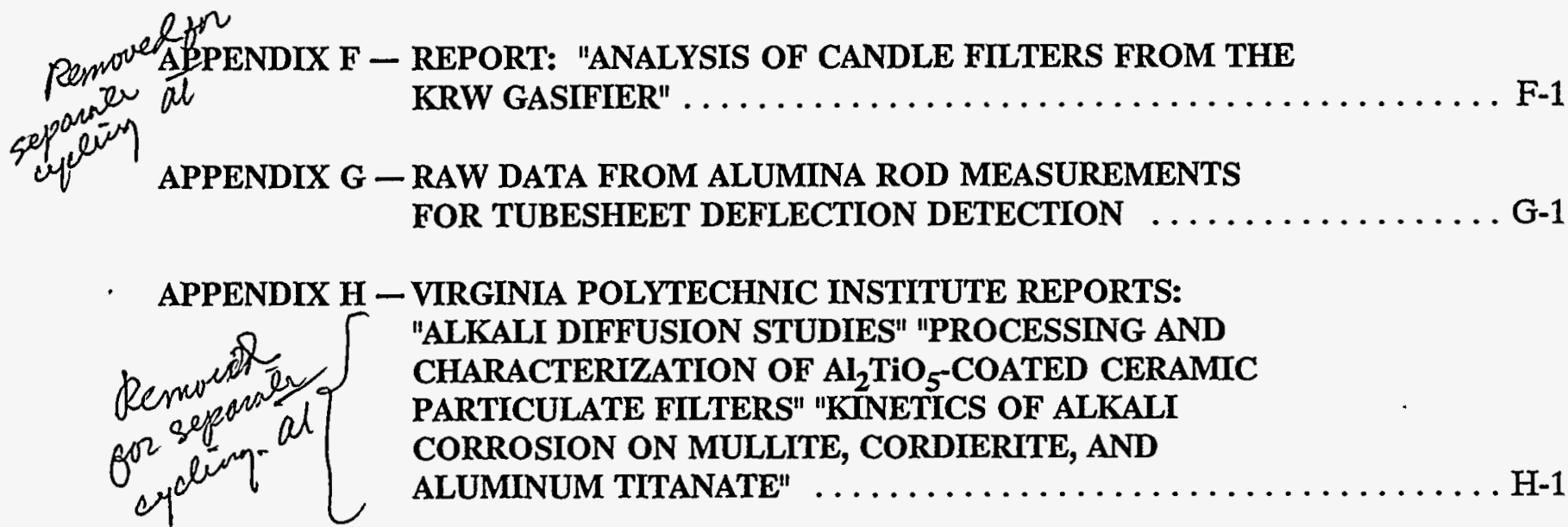




\section{LIST OF ILLUSTRATIONS}

Figure 1-1. C-ring specimens from a ceramic candle $\ldots \ldots \ldots \ldots \ldots \ldots \ldots \ldots$

Figure 1-2. Maximum stress comparisons of 0.5-in and 0.75-in c-ring specimens: Schumacher Diaschumalith F40 ............. 1-6

Figure 1-3. Maximum stress values for a Refractron 50/5 with 505 binder

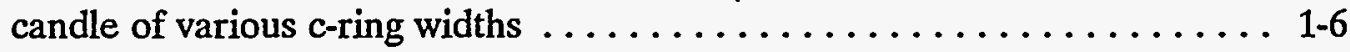

Figure 1-4. Maximum stress comparisons of 0.5-in and 0.75-in c-ring tension specimens: Refractron $70 / 3$ with $442-\mathrm{T}$ binder $\ldots \ldots \ldots \ldots \ldots$ 1-7

Figure 1-5. Maximum stress comparisons of 0.5 -in and 0.75-in c-ring compression specimens: Refractron $70 / 3$ with $442-\mathrm{T}$ binder $\ldots \ldots \ldots \ldots$ 1-7

Figure 1-6. Maximum stress comparison of c-ring tension with c-ring

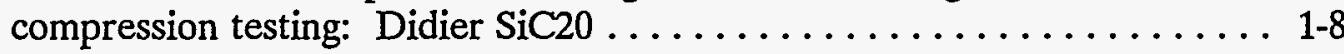

Figure 1-7. C-ring tension test results of a Schumacher Diaschumalith F40 candle pulsed 5,000 times with ambient air while at

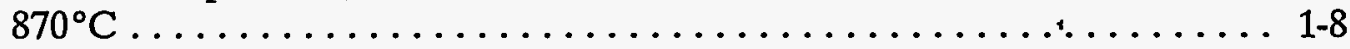

Figure 1-8. C-ring tension test results of an IFP LayCer candle pulsed 5,000 times with ambient air while at $870^{\circ} \mathrm{C} \ldots \ldots \ldots \ldots \ldots \ldots \ldots \ldots \ldots \ldots$

Figure 1-9. Room temperature c-ring tension test results of a Didier $\mathrm{SiC} 20$ candle pulsed 5,000 times with ambient air while at

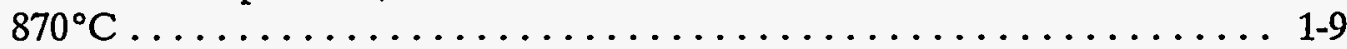

Figure 3-1. Ceramic Candle filter element $\ldots \ldots \ldots \ldots \ldots \ldots \ldots \ldots \ldots \ldots \ldots \ldots$

Figure 3-2. Thermal exposure sample vessel $\ldots \ldots \ldots \ldots \ldots \ldots \ldots \ldots \ldots \ldots$ 3-7

Figure 3-3. Schematic of dual flow-through thermal exposure system $\ldots \ldots \ldots \ldots$ 3-9

Figure 3-4. Candle specimen placement inside the exposure vessel $\ldots \ldots \ldots \ldots$ 3-10

Figure 3-5. Graph of the cumulative thermal exposure system up-time for Schumacher andle specimens . ..................... 3-13

Figure 3-6. Graph of the cumulative thermal exposure system up-time for Refractron $70 / 3$ with $442-\mathrm{T}$ binder candle specimens ........... 3-14

Figure 3-7. Temperature measurements from the data acquisition system of a $870^{\circ} \mathrm{C}$ exposure test in the stainless steel ("B") system . . . . . . 3-16

Figure 3-8. Temperature measurements from the data acquisition system of a $980^{\circ} \mathrm{C}$ exposure test in the Haynes ("C") system . . . . . . . . 3-17 


\section{LIST OF ILLUSTRATIONS (CONTINUED)}

Figure 3-9. C-ring specimens from a ceramic candle $\ldots \ldots \ldots \ldots \ldots \ldots \ldots \ldots$

Figure 3-10. C-ring testing sequence from candle filter $\ldots \ldots \ldots \ldots \ldots \ldots \ldots$

Figure 3-11. Bench-scale filter test facility $\ldots \ldots \ldots \ldots \ldots \ldots \ldots \ldots \ldots \ldots \ldots$

Figure 3-12. $\quad$ Fibrosic tubesheet $\ldots \ldots \ldots \ldots \ldots \ldots \ldots \ldots \ldots \ldots \ldots \ldots \ldots$

Figure 3-13. Middle section of Fibrosic tubesheet $\ldots \ldots \ldots \ldots \ldots \ldots \ldots \ldots \ldots$

Figure 3-14. Section of Fibrosic tubesheet tested $\ldots \ldots \ldots \ldots \ldots \ldots \ldots \ldots \ldots$

Figure 3-15. End-view of Fibrosic tubesheet tested $\ldots \ldots \ldots \ldots \ldots \ldots \ldots$

Figure 3-16. Cross-sectional view of candle hole in Fibrosic tubesheet $\ldots \ldots \ldots$. $\ldots 31$

Figure 4-1. Maximum stress comparisons of 0.5 -inch with 0.75 -inch c-ring specimens for a Schumacher Diaschumalith F40 candle . . . . . . . . 4-9

Figure 4-2. Maximum stress values for a Refractron 50/5 with 505 binder candle of various $c$-ring widths $\ldots \ldots \ldots \ldots \ldots \ldots \ldots \ldots \ldots . \ldots \ldots$

Figure 4-3. Maximum stress comparisons of 0.5-inch with 0.75-inch c-ring tension specimens for a Refractron $70 / 3$ with $442-\mathrm{T}$ binder candle ................................ 4-10

Figure 4-4. Maximum Stress comparisons of 0.5 -inch with 0.75 -inch c-ring compression specimens for a Refractron $70 / 3$ with $442-\mathrm{T}$ binder candle

Figure 4-5. Maximum stress comparison of c-ring tension testing with c-ring compression testing for a Didier SiC candle .

Figure 4-6. Maximum stresses of a heat treated Refractron 50/5 with 505

binder candle c-rings to determine the effect of machining

Figure 4-7. C-ring tension test results of a Schumacher Diaschumalith F40 candle pulsed 5,000 times with ambient air while at $870^{\circ} \mathrm{C}$

Figure 4-8. C-ring tension test results of an IFP LayCer candle pulsed 5,000 times with ambient air while at $870^{\circ} \mathrm{C}$

Figure 4-9. Room temperature c-ring tension test results of a Didier SiC20 candle pulsed 5,000 times with ambient air while at $870^{\circ} \mathrm{C}$ 


\section{LIST OF ILLUSTRATIONS (CONTINUED)}

Figure 4-10. Schumacher Diaschumalith F40 candle exposed to $95 \mathrm{ppm}$ $\mathrm{NaCl}$ and $20 \%$ steam at $870^{\circ} \mathrm{C}$ (no pulse cleaning): c-ring tested at $870^{\circ} \mathrm{C}$

Figure 4-11. Schumacher Diaschumalith F40 candle exposed to $65 \mathrm{ppm}$

$\mathrm{NaCl}$ and $20 \%$ steam at $980^{\circ} \mathrm{C}$ : c-ring tension test at $980^{\circ} \mathrm{C}$

Figure 4-12. Schumacher Diaschumalith F40 candle exposed to $65 \mathrm{ppm}$ $\mathrm{NaCl}$ and $20 \%$ steam at $980^{\circ} \mathrm{C}$ : c-ring compression test at $980^{\circ} \mathrm{C}$

Figure 4-13. Schumacher Diaschumalith F40 candle exposed to $20 \mathrm{ppm}$

$\mathrm{NaCl}$ and $15 \%$ steam at $870^{\circ} \mathrm{C}$ : c-ring tension test at $870^{\circ} \mathrm{C}$

Figure 4-14. Schumacher Diaschumalith F40 candle exposed to $20 \mathrm{ppm}$

$\mathrm{NaCl}$ and $15 \%$ steam at $870^{\circ} \mathrm{C}$ : c-ring compression test at

$870^{\circ} \mathrm{C}$

Figure 4-15. Refractron 70/3 with 442-T binder candle exposed to $20 \mathrm{ppm}$

$\mathrm{NaCl}$ and $15 \%$ steam at $870^{\circ} \mathrm{C}$ for 100 hours (no pulse

cleaning): c-ring tested at $870^{\circ} \mathrm{C}$

Figure 4-16. Refractron 70/3 with 442-T binder candle exposed to $20 \mathrm{ppm}$

$\mathrm{NaCl}$ and $15 \%$ steam at $870^{\circ} \mathrm{C}$ : c-ring tension test at $870^{\circ} \mathrm{C}$

Figure 4-17. Refractron 70/3 with 442-T binder candle exposed to $20 \mathrm{ppm}$

$\mathrm{NaCl}$ and $15 \%$ steam at $870^{\circ} \mathrm{C}$ : c-ring compression test at

$870^{\circ} \mathrm{C}$

Figure 4-18. Refractron 70/3 with 442-T binder candle exposed to $20 \mathrm{ppm}$

$\mathrm{NaCl}$ and $15 \%$ steam at $980^{\circ} \mathrm{C}$ : c-ring tension test at $980^{\circ} \mathrm{C}$

Figure 4-19. Refractron 70/3 with 442-T binder candle exposed to $20 \mathrm{ppm}$

$\mathrm{NaCl}$ and $15 \%$ steam at $980^{\circ} \mathrm{C}$ : c-ring compression test at

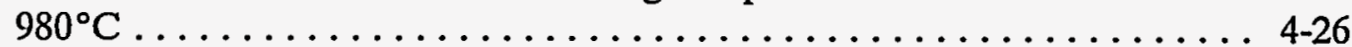

Figure 4-20. KRW candles: c-ring tension tests $\ldots \ldots \ldots \ldots \ldots \ldots \ldots \ldots \ldots \ldots$

Figure 4-21. KRW candles: $c$-ring compression tests $\ldots \ldots \ldots \ldots \ldots \ldots \ldots \ldots$

Figure 4-22. Micrograph of Schumacher F40/Unused: Outer surface

(210X)

Figure 4-23. Micrograph of Schumacher F40/20 ppm NaCl/15\%

$\mathrm{H}_{2} \mathrm{O} / 870^{\circ} \mathrm{C} / 1,000$ hours: Outer surface (200X)

Figure 4-24. Micrograph of Schumacher F40/Unused: Cross-section

(91X) 


\section{LIST OF ILLUSTRATIONS (CONTINUED)}

Figure 4-25. Micrograph of Schumacher F40/20 ppm NaCl/15\%

$\mathrm{H}_{2} \mathrm{O} / 870^{\circ} \mathrm{C} / 1,000$ hours: Cross-section (80X)

Figure 4-26. Micrograph of Refractron 70/3 with 442-T/Unused: Outer surface $(200 \mathrm{X})$

Figure 4-27. Micrograph of Refractron 70/3 with 442-T/20 ppm

$\mathrm{NaCl} / 15 \% \mathrm{H}_{2} \mathrm{O} / 870^{\circ} \mathrm{C} / 1,000$ hours: Outer surface $(200 \mathrm{X})$

Figure 4-28. Micrograph of Refractron 70/3 with 442-T/Unused: Inner surface $(80 \mathrm{X})$

Figure 4-29. Micrograph of Refractron 70/3 with 442-T/20 ppm

$\mathrm{NaCl} / 15 \% \mathrm{H}_{2} \mathrm{O} / 870^{\circ} \mathrm{C} / 1,000$ hours: Inner surface $(80 \mathrm{X})$

Figure 4-30. Micrograph of Refractron 70/3 with 442-T/20 ppm

$\mathrm{NaCl} / 15 \% \mathrm{H}_{2} \mathrm{O} / 870^{\circ} \mathrm{C} / 1,000$ hours: Inner surface $(200 \mathrm{X})$

Figure 4-31. Fibrosic candle permeability: Accelerated pulse cleaning at $870^{\circ} \mathrm{C}$

Figure 4-32. Fibrosic candle permeability: 100 hour operational filtration test at $870^{\circ} \mathrm{C}$

Figure 4-33. Displacement of an alumina rod on the surface of the

Fibrosic tubesheet

Figure 4-34. Location of alumina rod on Fibrosic tubesheet $\ldots \ldots \ldots \ldots \ldots \ldots$ 4-44

Figure 4-35. Topographic map of the Fibrosic tubesheet after load testing at $870^{\circ} \mathrm{C}$

Figure 4-36. Overlay of topographic map with a drawing of the Fibrosic tubesheet

Figure 4-37. Three dimensional representation of the Fibrosic tubesheet surface

Figure 6-1. Unused Schumacher Diachumalith F40: c-ring tension and compression tests at various temperatures

Figure 6-2. Unused Refraction 70/3 with 442-T binder: c-ring tension and compression at various temperatures .

Figure 6-3. Load versus displacement curves for the Schumacher F40 at various temperatures 


\section{LIST OF ILLUSTRATIONS (CONCLUDED)}

Figure 6-4. Schumacher F40/c-ring tension at $870^{\circ} \mathrm{C}$ : Strength loss due to thermal and thermal/chemical degradation

Figure 6-5. Refractron $70 / 3 \mathrm{w} / 442-\mathrm{T} / \mathrm{c}$-ring tension at $870^{\circ} \mathrm{C}$ : Strength loss due to thermal and thermal/chemical degradation 6-7 


\section{LIST OF TABLES}

Table 3-1. Thermal exposure test conditions 3-6

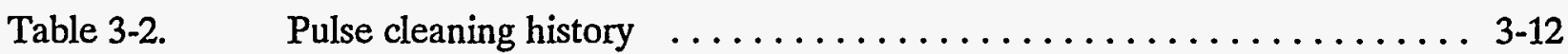

Table 4-1. C-ring tension testing: Schumacher Diaschumalith $\ldots \ldots \ldots \ldots \ldots$ 4-2

Table 4-2. C-ring tension testing: Refractron $\ldots \ldots \ldots \ldots \ldots \ldots \ldots \ldots \ldots \ldots \ldots$

Table 4-3. C-ring tension testing: IFP LayCer and Didier SiC20 $\ldots \ldots \ldots \ldots \ldots$ 4-4

Table 4-4. C-ring compression testing: Schumacher Diaschumalith $\ldots \ldots \ldots \ldots$ 4-5

Table 4-5. C-ring compression testing: Refractron $\ldots \ldots \ldots \ldots \ldots \ldots \ldots \ldots$ 4-6

Table 4-6. C-ring compression testing: IFP LayCer/Didier SiC20 $\ldots \ldots \ldots \ldots \ldots$ 4-7

Table 4-7. Summary of c-ring tension/compression tests investigating the effect of sample width on c-ring strength measurement $\ldots \ldots \ldots \ldots \ldots$ 4-8

Table 4-8: $\quad$ Maximum stress values for a Didier $\mathrm{SiC}$ candle $\ldots \ldots \ldots \ldots \ldots \ldots$ 4-12

Table 4-9. Maximum stress values for an unused Refractron 50/5 with 505 binder that had c-rings cut before and after heat

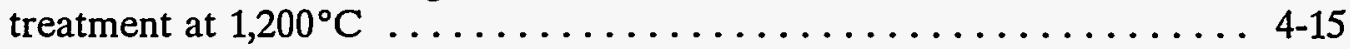

Table 4-10. Maximum stress summary of c-ring tension tests investigating the effect of 5,000 ambient air pulses on candles at $870^{\circ} \mathrm{C} \ldots \ldots \ldots$... $4-16$

Table 4-11. C-ring test results summary of Schumacher candles used in the long term thermal exposure tests $\ldots \ldots \ldots \ldots \ldots \ldots \ldots \ldots$. $4-19$

Table 4-12. C-ring test results summary of Refractron candles used in the long term thermal exposure tests $\ldots \ldots \ldots \ldots \ldots \ldots \ldots \ldots \ldots \ldots, 4-21$

Table 4-13. C-ring tests on KRW candles $\ldots \ldots \ldots \ldots \ldots \ldots \ldots \ldots \ldots \ldots \ldots \ldots \ldots \ldots .29$

Table 4-14. X-Ray diffraction summary $\ldots \ldots \ldots \ldots \ldots \ldots \ldots \ldots \ldots \ldots \ldots \ldots \ldots$

Table 4-15. Fibrosics candle test summary $\ldots \ldots \ldots \ldots \ldots \ldots \ldots \ldots \ldots .40 \ldots$ 


\section{SECTION 1}

\section{EXECUTIVE SUMMARY}

The development of advanced coal-fueled power generation systems, such as integrated gasification-combined cycles and pressurized fluidized-bed combustors (PFBC), can provide costeffective alternatives for power generation, improve coal utilization, and decrease our dependence on oil and gas. The direct firing of coal produces particulate matter which must be removed for both environmental and process reasons. For example, in a PFBC, the gas must be cleaned of particulate matter before expanding through the turboexpander in order to protect the downstream turbine components. Under the auspices of the U.S. Department of Energy (DOE), ceramic candle filters are being developed for high-temperature applications to increase the efficiency of current and advanced fuel combustion processes. The filters protect downstream equipment from erosion and impingement of particulate matter in the hot exhaust gases. Ceramic candle filters are rigid, closed-ended porous cylinders with a flange on the open-ended side. The flange at the open end allows the candle to be suspended by a plate (tubesheet) in the filter vessel.

Ceramic candles have shown promise in hot gas filtration applications, but they have encountered durability problems during actual use in hostile, high-temperature environments. The objective of this project is to identify thermal and chemical degradation mechanisms in candle

filters. Sub-objectives are to (a) develop test procedures, and (b) apply the test procedures to testing and predicting performance of representative candle materials.

At the start of this project, the mechanisms involved in the degradation of candle filters were not understood. The degradation mechanisms were broken into two main areas, thermal and chemical. The investigations in the chemical mechanisms were performed by Virginia Polytechnic 
Institute (VPI) under the project under a major subcontract to Acurex Environmental. Acurex Environmental investigated the thermal and the combined thermal and chemical mechanisms. The primary tests completed were performed on candles composed of a support structure of silicon carbide grains held together by an alumino-silicate binder.

Most of the ceramic candle examinations conducted by Acurex Environmental were performed on Schumacher Diaschumalith (Schumacher) and Refractron candles. A report on the analysis of Schumacher candles exposed to the KRW gasifier is provided in Appendix F.

The Schumacher candle consists of two porous layers. The outer layer acts as the filtration surface and is made of a thin, relatively dense (wash coat) layer of alumino-silicate fibers in an alumino-silicate binder. The thick inner layer primarily supports the thin outer filtration layer of the candle and consists of a highly porous structure.

The two-layered Refractron 70/3, Refractron 50/5, and IFP LayCer candles are similar to the Schumacher candles in that they are made by bonding the silicon carbide ( $\mathrm{SiC}$ ) grains together with an alumino-silicate clay binder and they have two separate layers (one for filtration and one for structural support). Similar to the Schumacher, the $9 \mathrm{~mm}$ inner supporting layer consists of coarse $\mathrm{SiC}$ grains. The thin $(1 \mathrm{~mm})$ outer filtration layer is made of fine $\mathrm{SiC}$ grains.

The homogeneous single layer Didier SiC20 candle does not have two separate layers. The Didier candle uses the same sized $\mathrm{SiC}$ grains throughout the whole candle.

Acurex Environmental also investigated a candle that is not made of SiC grains. Industrial Filter and Pump (IFP) has developed a fibrous filter with a vacuum-formed body which is posttreated to strengthen the high stress areas and modify the surface pore size. Acurex Environmental examined the durability of the IFP Fibrosic candle and tubesheet in this project.

Under operating conditions, ceramic candle filter systems use pulse cleaning as the filtercleaning mechanism. Pulse cleaning of candles is accomplished by introducing a sharp pulse of highpressure gas into the individual candle via a manifold. The gas is usually delivered from the cleaning nozzle at near sonic velocity. Also, because of cost and material limitations, the pulse gas 
is not heated and is therefore, at about room temperature. In addition, because of the expansion across the nozzle, the pulse gas is adiabatically cooled. The relatively cold gas is introduced into the candle, which is at operating temperature (typically, $370^{\circ} \mathrm{C}\left(700^{\circ} \mathrm{F}\right)$ to $1,000^{\circ} \mathrm{C}\left(1,830^{\circ} \mathrm{F}\right)$.

The early method used for strength comparisons was four-point flexure tests, but C-ring testing was selected as the better method of testing the strength degradation of ceramic candles. Acurex Environmental developed and designed the testing system used for this project. C-rings are obtained by sectioning rings out of the candles and then making a longitudinal slit (perpendicular to the section direction) on one side of the ring (see Figure 1-1). C-ring testing is an excellent method because it leaves the candle surfaces (inner bore and the outer surface of the tube) intact, and thus leaves intact the surface flaw population.

Figure 1-1 also shows how the c-ring specimens are loaded (indicated by the arrows). Under tension, the inner surface of the candle at a point opposite the slit experiences the maximum

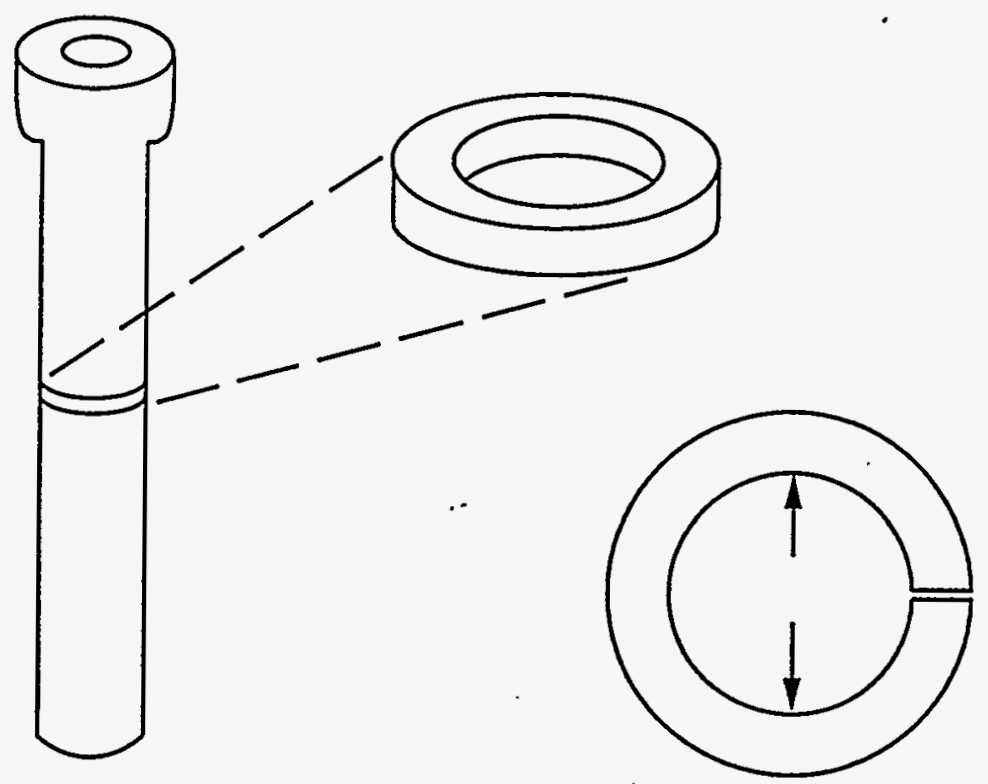

TENSION ID in tension

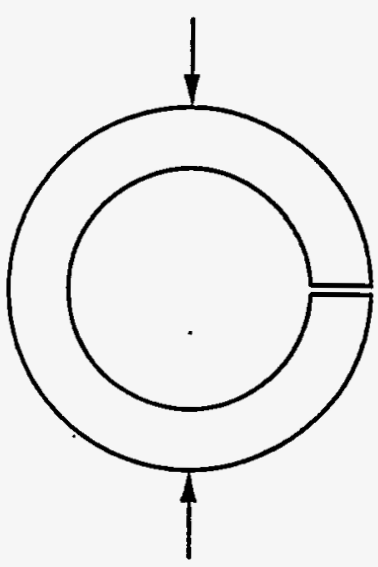

COMPRESSION $O D$ in tension

Figure 1-1. C-ring specimens from a ceramic candle 
tensile stress, while the outer surface experiences the maximum compressive stress. Under compression, the outside surface (opposite the slit) bears the maximum tensile stress. Ceramics are much stronger under compressive than tensile stresses; therefore, failure/fracture of the c-ring will originate at the surface with the maximum tensile stress. This phenomenon allows focusing on a surface (inner or outer) to investigate its strength degradation under different environmental conditions. The areas of interest (opposite the slit in the c-ring) are the inner surface for c-ring tension testing $\left(R=R_{1}\right)$ and the outer surface for c-ring compression testing $\left(R=R_{2}\right)$.

The analytical expression for the maximum c-ring stress is based on the bending of curved beams, and is as follows:

$$
\sigma=\frac{F T}{2 W R\left[\frac{\left(R_{1}+R_{2}\right) \ln \left(R_{2} / R_{1}\right)}{2}-T\right]} \text {, }
$$

where,

$$
\begin{aligned}
& \sigma=\text { maximum stress } \\
& F=\text { maximum load } \\
& \mathrm{R}=\mathrm{R}_{1} \text { for tensile loading of c-ring (tension tests) } \\
& \quad \mathrm{R}_{2} \text { for compressive loading of c-ring (compression tests) } \\
& \mathrm{R}_{1}=\text { Inside radius of c-ring } \\
& \mathrm{R}_{2}=\text { Outside radius of c-ring } \\
& \mathrm{W}=\text { width/thickness of c-ring } \\
& \mathrm{T}=\mathrm{R}_{2}-\mathrm{R}_{1} .
\end{aligned}
$$

C-ring testing was performed to justify the use of this approach for strength measurement of ceramic candle filters and to validate the use of the above equation for maximum stress calculations. The typical c-ring specimen width is 0.75 inches. Due to the design and size 
limitations of the thermal exposure test facility, c-ring widths of 0.50 inches were used. To investigate the possibility of specimen size influencing the strength measurements, Acurex Environmental performed c-ring tension and compression tests on 0.50-, 0.75-, 1.00-, and 1.25-in. specimens on Schumacher and Refractron candles. Figures 1-2, 1-3, 1-4, and 1-5 summarizes these tests.

Figures 1-2 through 1-5 demonstrate that the maximum stress values experienced with 0.5 -in c-ring specimens are representative of the strength of the candle. The optimum c-ring width would be 0.75 -in because it would be an inefficient use of material to use c-ring widths greater than 0.75 -in if 0.75 -in specimens would result in the same maximum stress value as the larger specimens. 0.5 -in specimens are acceptable, but they are less desirable because they are more fragile than the larger 0.75-in specimens. 0.5 -in specimens are also harder to work with at high temperature.

To investigate why tension strength levels were different from compression strengths, Acurex Environmental tested an unused homogenous candle made by Didier. The homogenous candle does not have a filtration layer that is different from the supporting body such as the Schumacher and Refractron candles. The Didier candle should therefore have the same strength in c-ring tension as in compression because the material on the inner surface is the same as on the outer surface. Figure 1-6 shows graphically that the strength of the material at the inner bore of the candle (via the tension test) had the same material strength as the material at outer filtration surface (via the compression test). This verifies the use of the stress equation for determining the strength of a material irrespective of the surface being examined.

One of the possible causes of the durability problems encountered by candle filters is thermal shock/thermal fatigue. It has been observed that candles exposed to operating conditions resulted in loss of strength. Acurex Environmental investigated the effect of ambient air pulses on candle strength at elevated temperatures. Figures 1-7, 1-8, and 1-9 summarizes the tests conducted. The candles were pulsed 5,000 times with ambient air down the inner bore while the candle was at $870^{\circ} \mathrm{C}\left(1,600^{\circ} \mathrm{F}\right)$. No c-ring compression tests were conducted because any strength degradation 


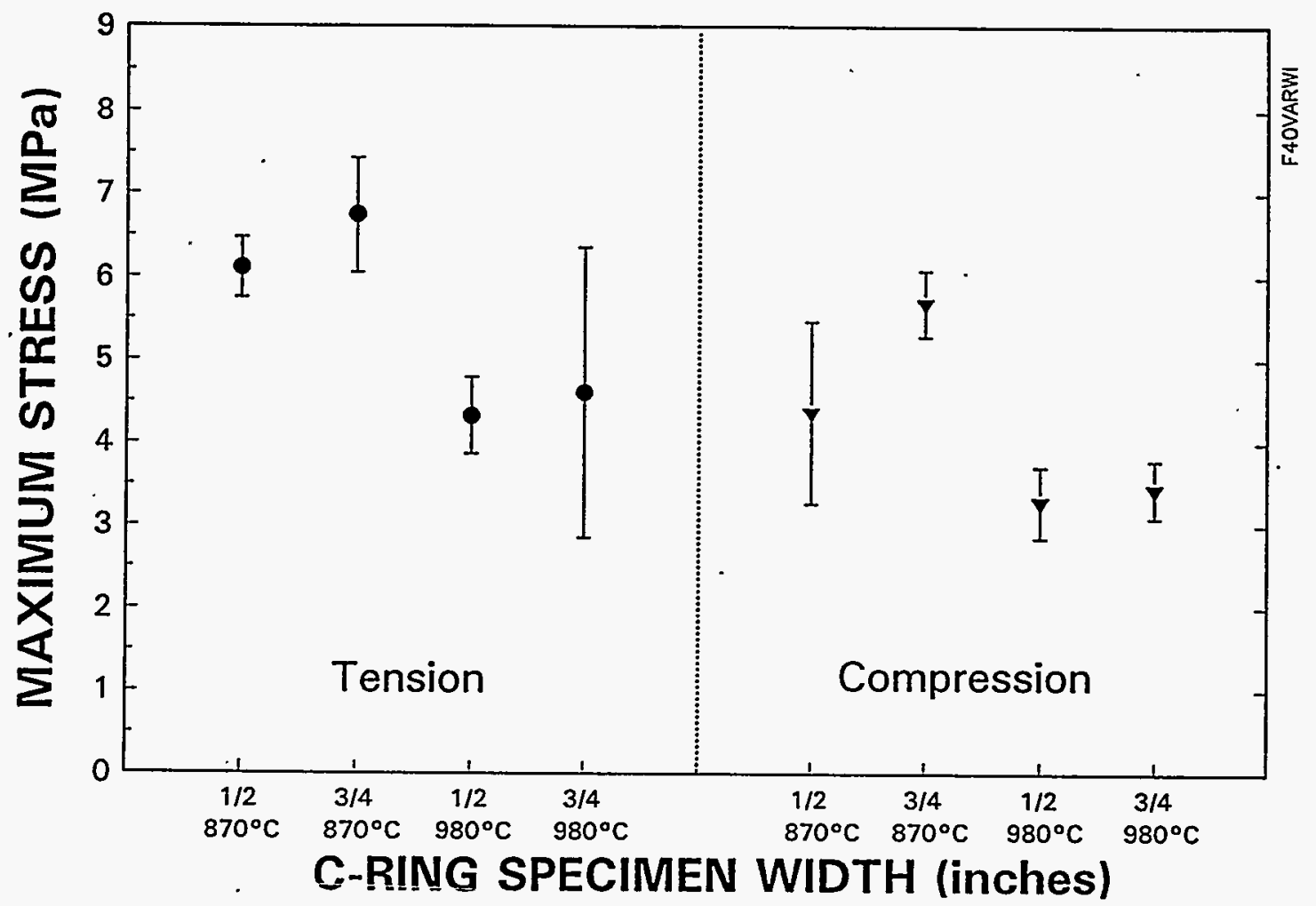

Figure 1-2. Maximum stress comparisons of 0.5 -in and 0.75 -in c-ring specimens: Schumacher Diaschumalith F40

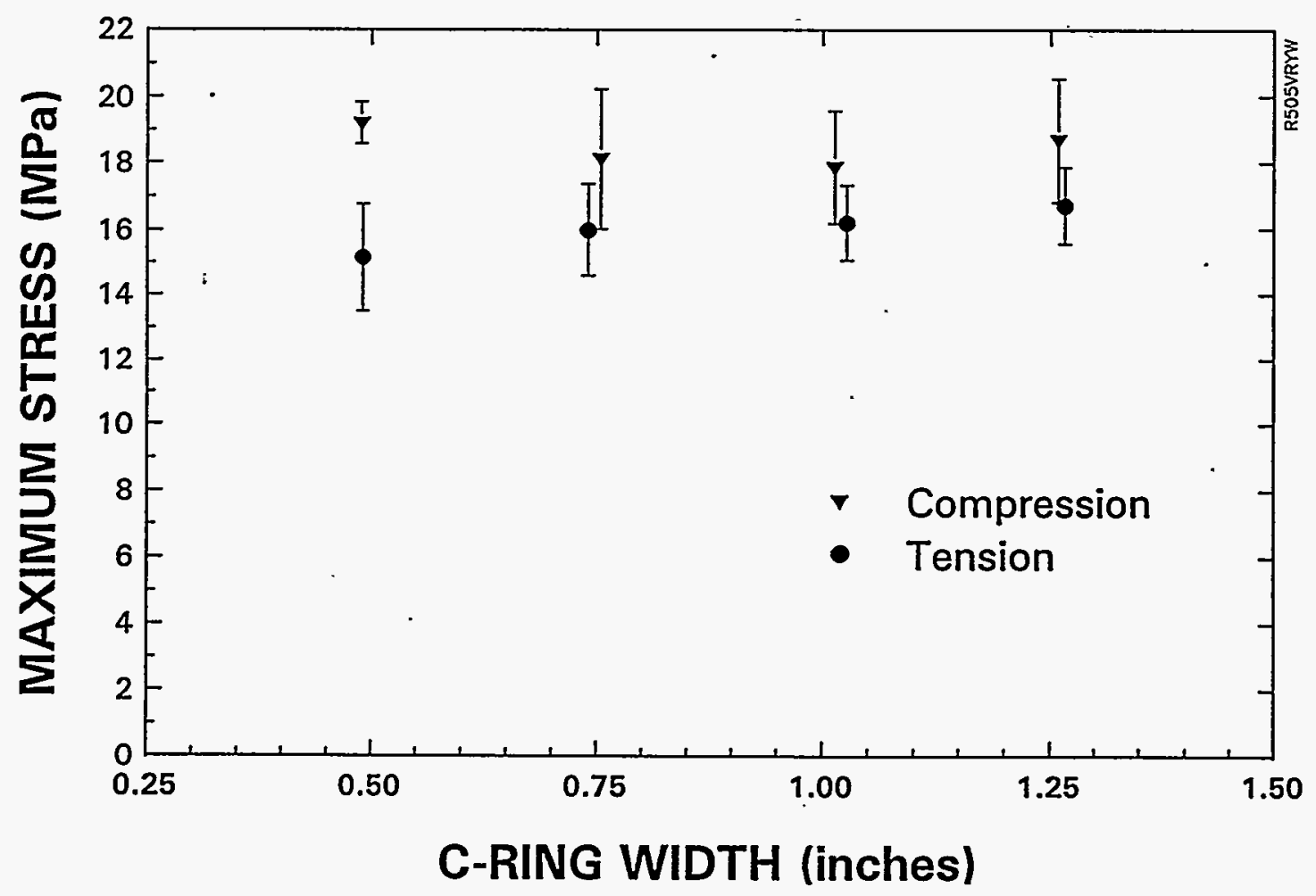

Figure 1-3. Maximum stress values for a Refractron $50 / 5$ with 505 binder candle of various $c$-ring widths 


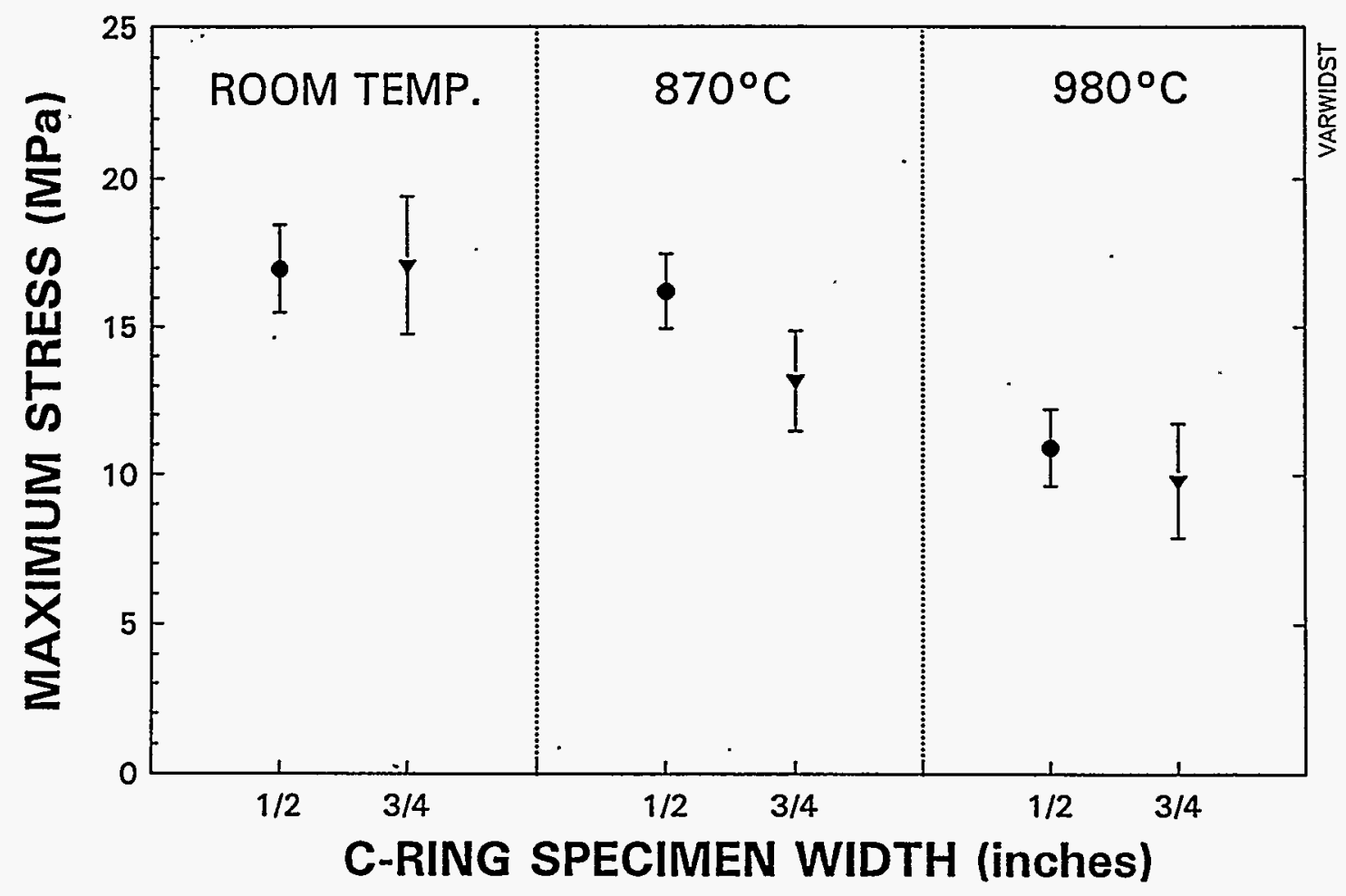

Figure 1-4. Maximum stress comparisons of 0.5-in and 0.75-in c-ring tension specimens: Refractron $70 / 3$ with $442-T$ binder

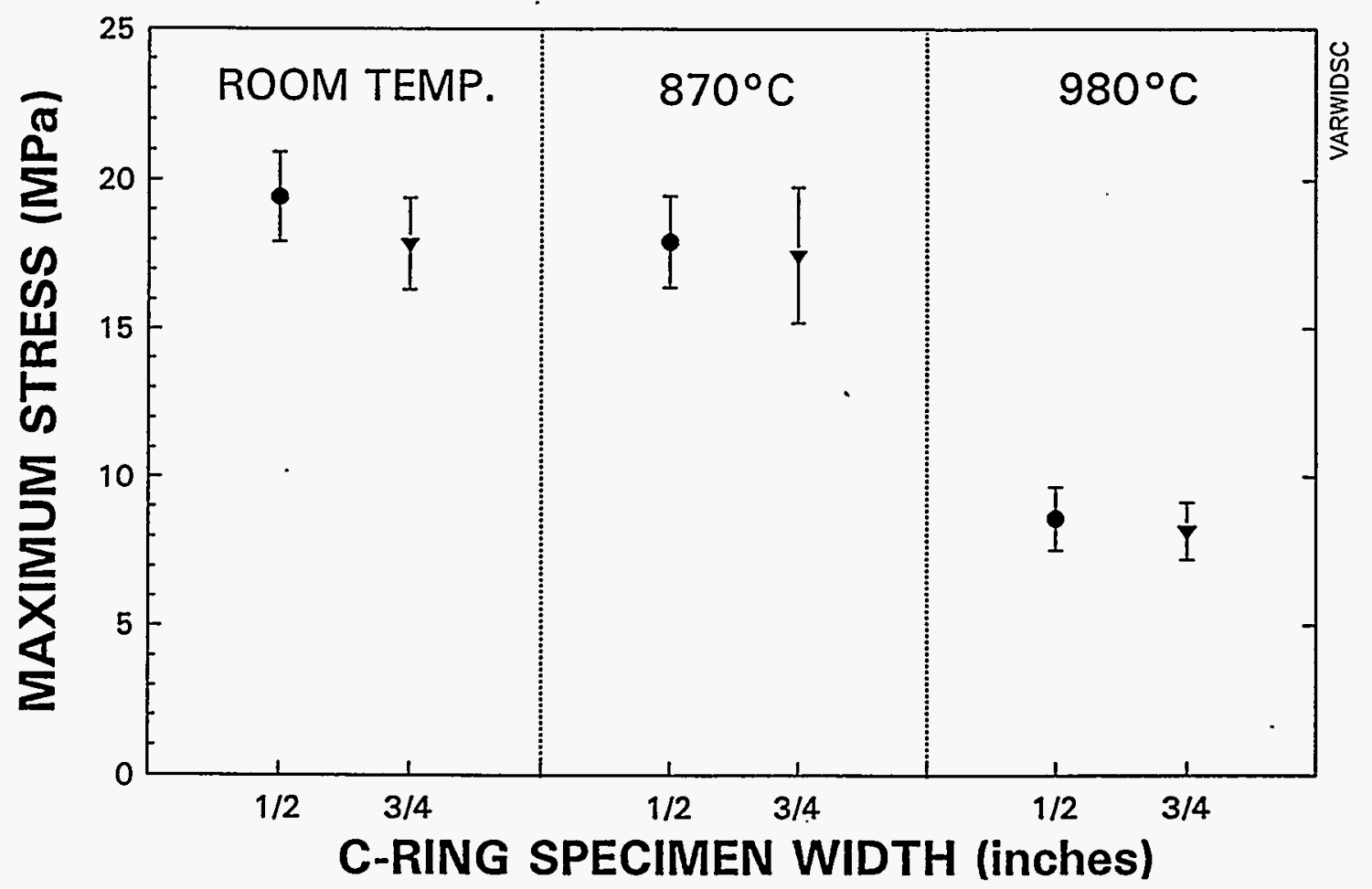

Figure 1-5. Maximum stress comparisons of 0.5-in and 0.75-in c-ring compression specimens: Refractron $70 / 3$ with $442-\mathrm{T}$ binder 


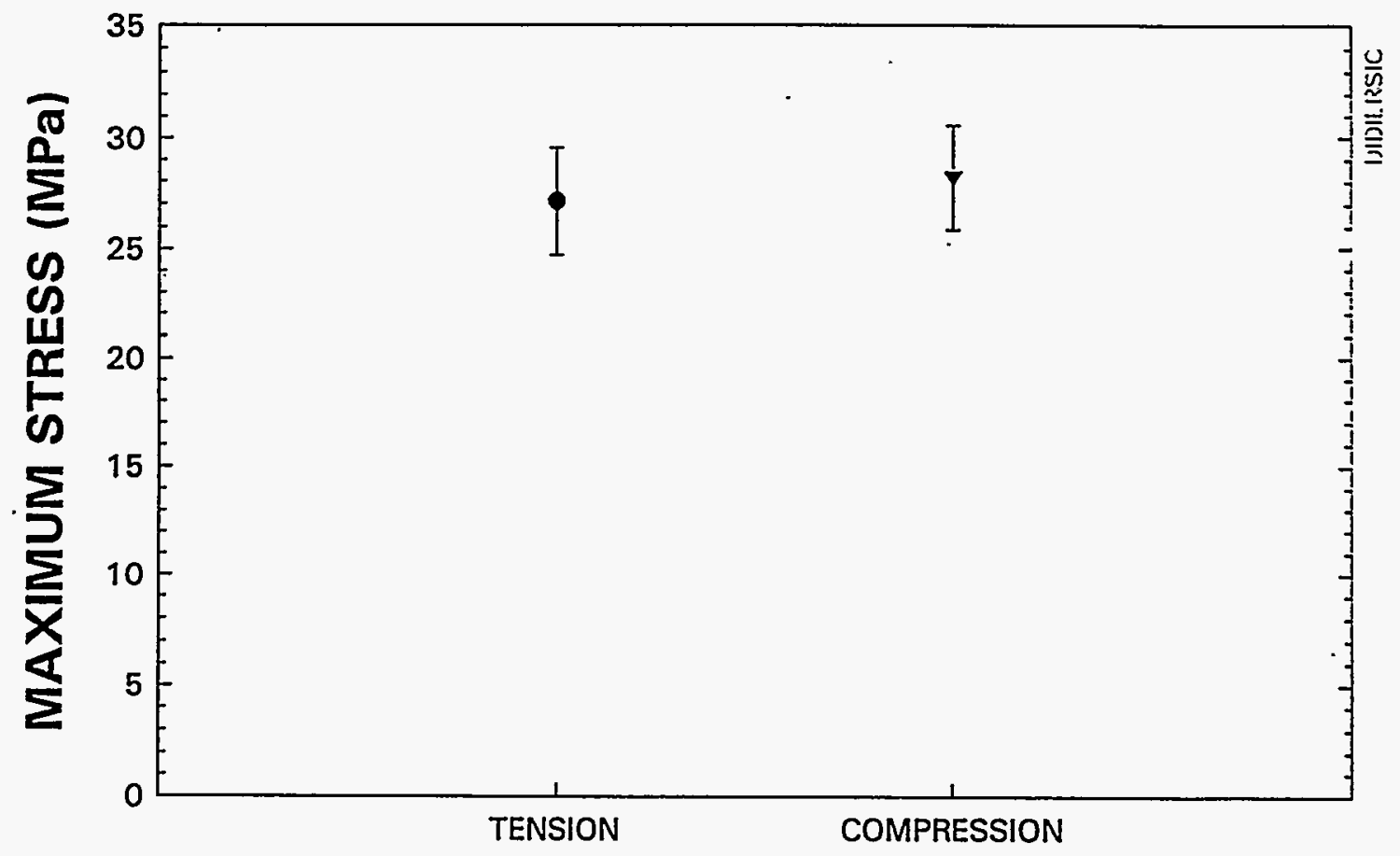

Figure 1-6. Maximum stress comparison of c-ring tension with c-ring compression testing: Didier SiC20

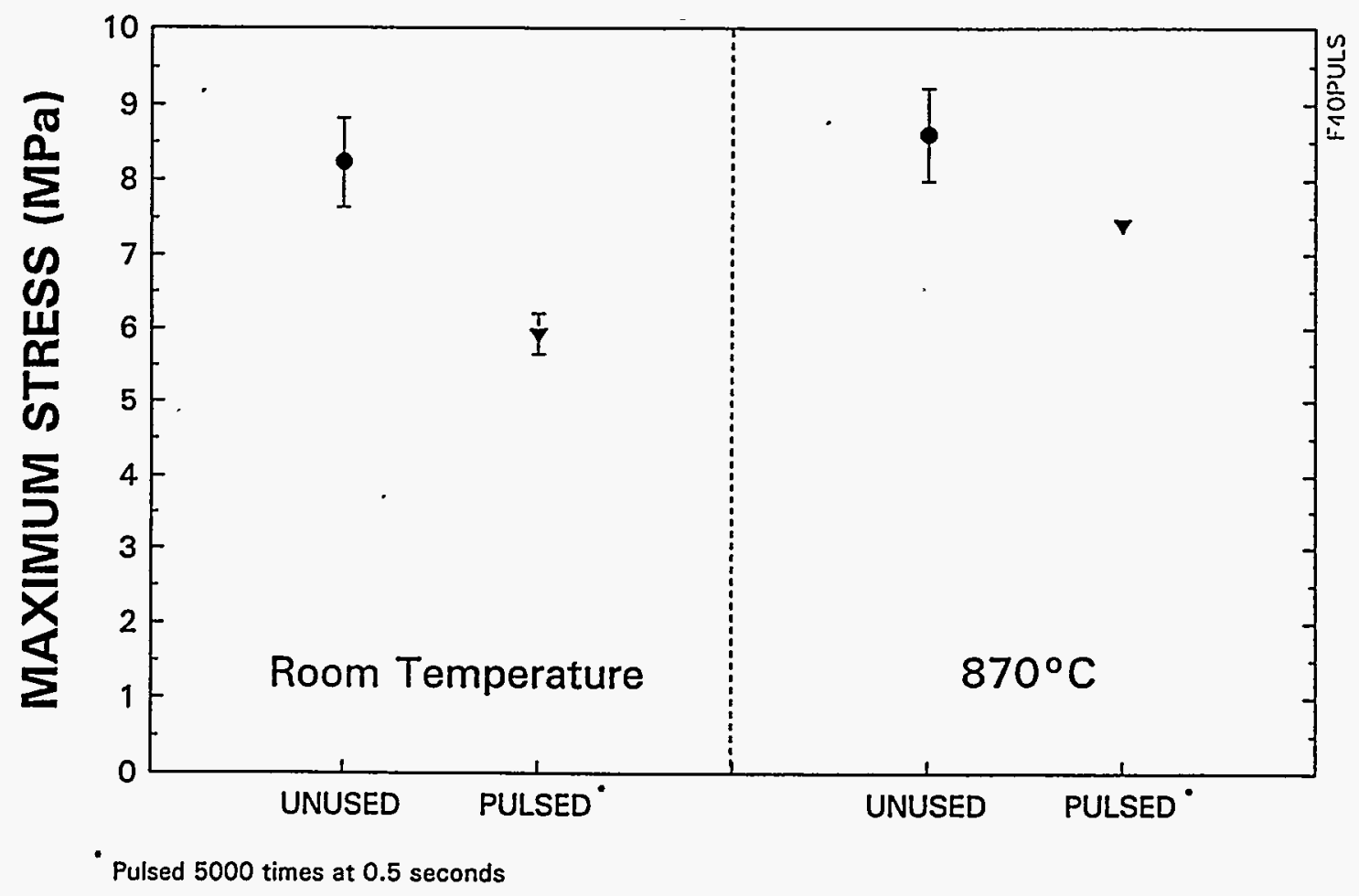

Figure 1-7. C-ring tension test results of a Schumacher Diaschumalith F40 candle pulsed 5,000 times with ambient air while at $870^{\circ} \mathrm{C}$ 


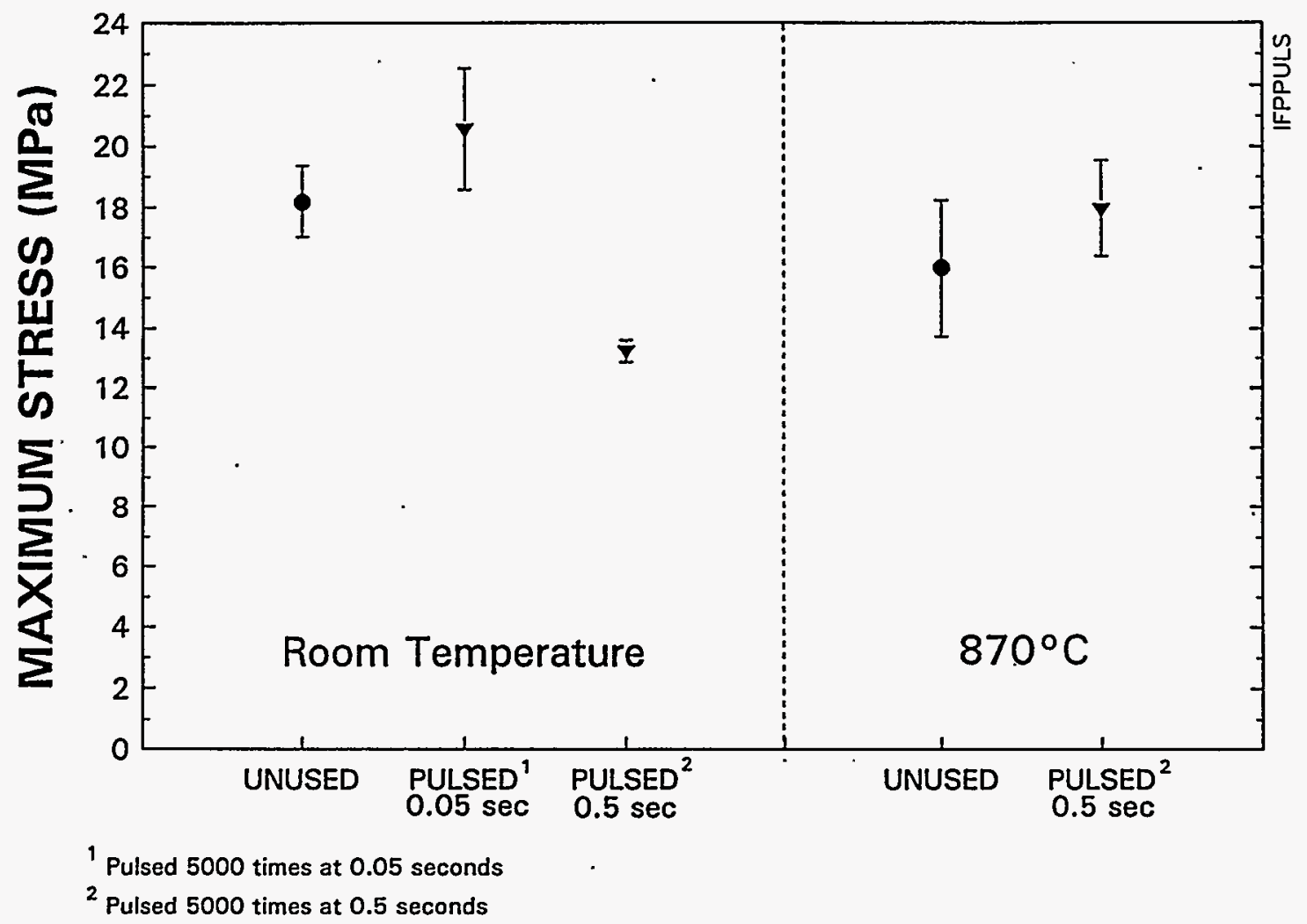

Figure 1-8. C-ring tension test results of an IFP Laycer candle pulsed 5,000 times with ambient air while at $870^{\circ} \mathrm{C}$

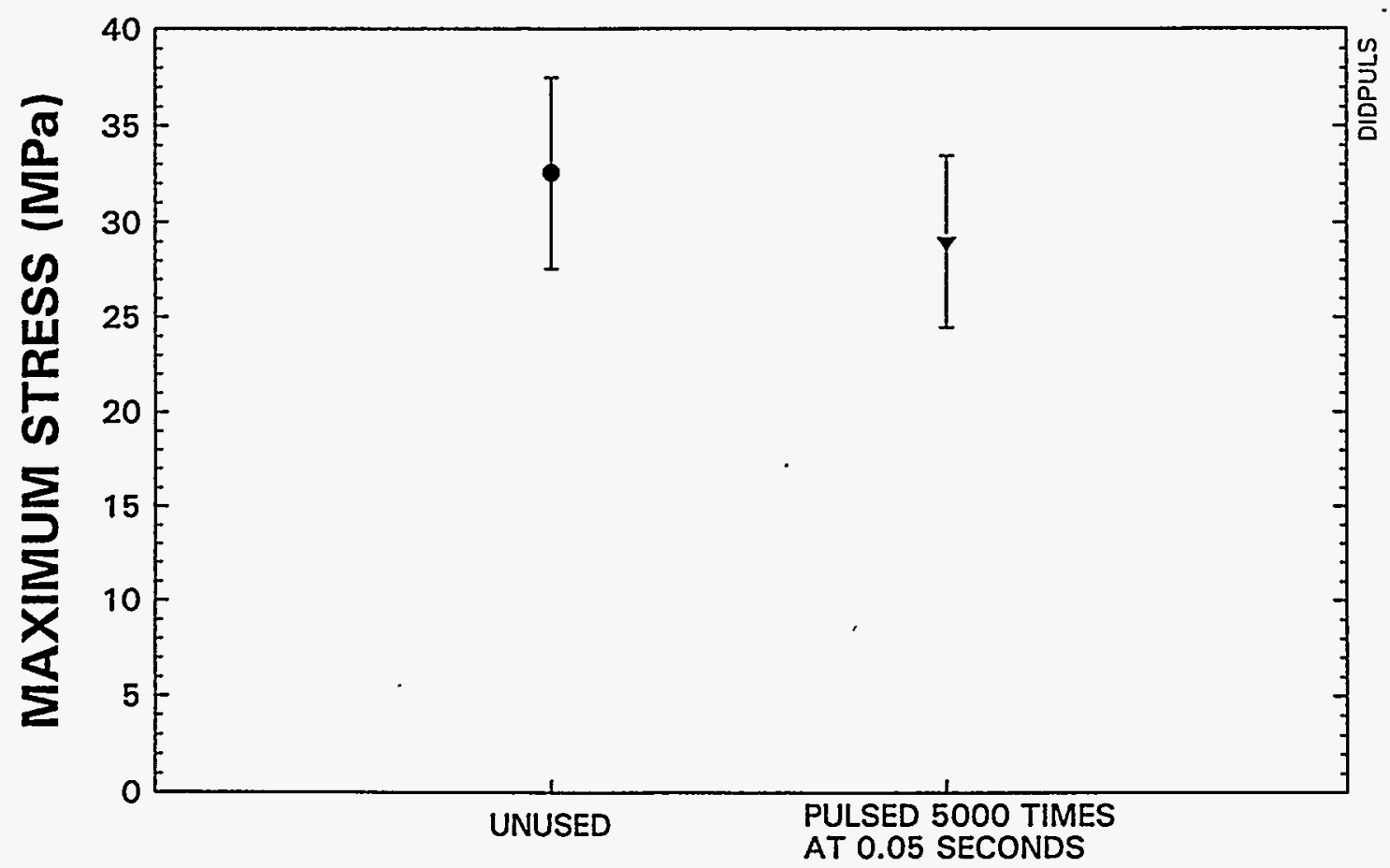

Figure 1-9. Room temperature c-ring tension test results of a Didier SiC20 candle pulsed 5,000 times with ambient air while at $870^{\circ} \mathrm{C}$ 
due to thermal shock from the pulse air would be most apparent on the inner surface of the candle (c-ring tension).

The unused candles have no history of pulse cleaning nor of temperature cycling. $t$ can be seen that the Schumacher and FP LayCer candles pulsed with time durations of 0.5 seconds exhibit room temperature strength loss. The strength loss due to these pulses can be attributed to thermal shock in which temperature gradients produce stresses under conditions that restrain the free expansion. The temperature distribution could be such that free expansion of each volume element would separate the individual volume elements in such a way that they would not fit together. $f$ the maximum stress for a material is reached, failure (such as cracking and spalling) will result. The effect of thermal stresses depends not only on the absolute level of stresses, but also the stress distribution, stress duration, and material characteristics (such as ductility, homogeneity, porosity, and presence of pre-existing flaws).

As a control, the unused candles (in Figures 1-7 and 1-8) tested at high temperature resulted in stress values within the range of room temperature tests of the same unused candles. This suggests that the elevation of temperature will not affect the strength of c-ring specimens if there is no change in the surface characteristics of the candle. The control also acts as a reference to which strength values from exposed candles can be compared.

With stress duration also being a determining factor, it can be seen that the FP LayCer and Didier candles pulsed at a time duration of 0.05 seconds (refer to Figures 1-8 and 1-9) do not show any room temperature strength loss (the averages are within their standard deviations). This series of room temperature tension test comparisons does imply that ambient air pulses to candles at operating temperatures cause strength degradation (possibly via micro-cracking on the inner bore of the candle) when the pulse duration is at least 0.5 seconds.

The purpose of the long-term exposure testing at Acurex Environmental was to examine the synergistic effects of long term exposure to temperature, alkali vapor, steam, and pulse cleaning on candle filter materials. 
Schumacher Diaschumalith F40 and Refractron 70/3 with 442-T binder candles were tested under the following conditions:

- $20 / 65 / 95 \mathrm{ppm} \mathrm{NaCl}$ (by volume)

- $15 / 20 \%$ steam (by volume)

- Atmospheric pressure

- $870^{\circ} \mathrm{C} / 980^{\circ} \mathrm{C}\left(1,600^{\circ} \mathrm{F} / 1,800^{\circ} \mathrm{F}\right)$

- With/without 0.5 -second pulse cleaning

- $100 / 400 / 500 / 1,000$ hours of exposure

The candle face velocities ranged between 8 to $17 \mathrm{ft} / \mathrm{min}$.

The Schumacher and Refractron candles did not retain their integrity when tested at $980^{\circ} \mathrm{C}$ $\left(1,800^{\circ} \mathrm{F}\right)$. Contamination from metals, such as $\mathrm{Fe}$ and $\mathrm{Cr}$, from the corrosion byproducts of the vessel and pre-vessel piping may have contributed to the degradation of the exposure candle specimens.

Cristobalite formation was detected in granular aluminosilicate by VPI in their hydrothermal tests. Strength degradation of the Schumacher candle can be attributed to the formation of cristobalite that was detected in the exposure specimens.

The initial strength degradation and subsequent strength increase of the Refractron candle may be attributed to the formation of albite. More investigation is needed on the effects of albite on the characteristics of the candle filter.

The modeling of the thermal/chemical degradation mechanisms to predict filter lifetime was unsuccessful.

Industrial Filter and Pump (IFP) has developed a fibrous filter that is different from the rigid candles (typically $\mathrm{SiC}$ grains held together by an alumino-silicate binder) tested above. The filter is a vacuum-formed body which is post-treated to strengthen the high stress areas and modify the surface pore size. In late 1991 and early 1992, Acurex Environmental performed durability testing (funded by EPRI) of the Fibrosic candle under development by IFP. In operation, the 
Fibrosic candles performed well (having high collection efficiency with low pressure drop), but the candle durability was suspect because the candles catastrophically failed during testing. These candles were assembled by gluing a flange onto the vacuum-formed body. The tests showed the glued joint to be the weak area. The burst tests of these filters showed the used candles to have a candle burst pressure of approximately half the unused candles. These measurements indicated there had been significant strength loss from use.

Since these original tests, IFP has developed the Fibrosics filter further and the preliminary indications are that the filter is much stronger than measured previously. Acurex Environmental assessed the durability of the filter by performing an accelerated pulse cleaning (15,000 pulses) test at $870^{\circ} \mathrm{C}\left(1,600^{\circ} \mathrm{F}\right)$ and a test with actual filtration operating conditions $(4,000 \mathrm{ppm}$ dust load at $870^{\circ} \mathrm{C}$ for 100 hours). Cylindrical burst pressure tests were performed to assess the effect of testing on the mechanical strength of the candle filters.

Both Fibrosic candles had collection efficiencies greater than $99.99 \%$ during and after the 15,000 pulse cleanings test and also the 100 hour operational filtration test. The unused Fibrosic candle (Fibro2800) tested in this project had a burst pressure of 20 psig. There was about a $25 \%$ drop in burst pressure for both of the Fibrosic candles tested as compared to the 50\% burst pressure loss for the earlier version of the Fibrosic candle. The modifications by IFP have improved the durability of the Fibrosic candle.

IFP has also been developing a fibrous ceramic tubesheet and candle hold-down system. This approach has appeal by reducing the amount of metal subjected to high temperature gas. There was no long term testing data of the structural integrity of the Fibrosic tubesheet at high temperature prior to this project. Acurex Environmental tried to simulate the "worst" case structural loading conditions that the tubesheet would encounter during operation. The tubesheet was loaded with 113 pounds, similar to that expected from the filter, dust, and hold-down plate at $870^{\circ} \mathrm{C}$ for 500 hours. The rate at which the tubesheet deflected was highest during the first 24 hours. After 500 hours, the Fibrosic tubesheet has a deflection/sag of about 0.1 inch (measured 
at the lowest point across the width of the tubesheet). Aside from a few minor cracks, the tubesheet retained its structural integrity.

To date, field demonstrations of ceramic candle filters have had limited success. Examination of $\mathrm{SiC}$ candle filters has shown that the filters experience significant strength degradation that limits the operational life of the candle filters. This project has provided a better understanding of the degradation mechanisms of candle filters which will allow for improved designs of candle filters and more effective adaptation to operational constraints. Before this project began, thermal degradation from pulse cleaning was thought to be insignificant. It obviously is a contributing factor in candle filter integrity. The information derived from this project has improved the level of knowledge concerning ceramic candle filters. 
$-14-$

This Page Intentionally Left Blank 


\section{SECTION 2}

\section{INTRODUCTION}

Under the auspices of the U.S. Department of Energy (DOE), high-temperature ceramic candle filters are being developed for use in advanced power generation systems such as the Integrated Gasification Combined Cycle (IGCC), Pressurized Fluidized-Bed Combustor (PFBC), and Direct Coal-Fired Turbine (DCFT). The direct firing of coal produces particulate matter which must be removed to meet both environmental and process limitations. The ceramic candles increase the efficiency of the advanced power generation systems and protect downstream equipment from erosion and impingement of particulate matter in the hot exhaust gases. Ceramic candle filters are rigid, closed-ended (capped on one side) porous cylinders which generally have a flange on the open-ended side. The flange at the open end allows the candle to be suspended by a tubesheet in the filter vessel.

Candle filters have shown promise, but have also encountered durability problems during use in hostile, high-temperature environments. Limitations in the candle lifetime lower the economic advantages of using candle filters for this application. Candles typically fail by cracking at the flange or in the body of the candle.

\section{$2.1 \quad$ PROBLEM STATEMENT}

Ceramic candle filters have encountered durability problems during actual use in advanced coal utilization projects. Filters have cracked during use at Grimethorpe PFBC and at the KRW gasifier. It has been observed that candles exposed to operating conditions have experienced loss of material strength. ${ }^{1}$ 
To date, the mechanisms that contribute to ceramic candle degradation are not well understood, and data on the properties of the candle filters at elevated temperatures were limited. The major degradation mechanisms of the candles are thought to be thermal fatigue and corrosion.

\subsection{PROJECT OBJECTIVE}

The objective of this project was to test and analyze ceramic candle filter materials and to evaluate the degradation mechanisms. The tests were conducted such that the effects of each degradation mechanism could be examined separately. The overall objective of the project was to (a) develop a better understanding of the thermal and chemical degradation mechanisms of ceramic candle filter materials in advanced coal utilization projects, (b) develop test procedures, and (c) recommend changes to increase filter lifetime.

\subsection{TEST SCOPE}

In order to assess the effects of operating conditions on the candle filters, both unused and used candles were tested. This project primarily tested the rigid Schumacher Diaschumalith F40 and Refractron 70/3 with 442-T binder candles, and the fibrous Fibrosic (Fibro2800) candle. C-ring testing was developed to evaluate the mechanical strength of rigid candle filters after being exposed to various environmental/exposure conditions. Some candles were exposed to accelerated pulse cleaning conditions to examine the strength degradation due to thermal shock. Prior to the beginning of this project, strength degradation due to thermal shock was thought to be minimal or nonexistent. Thermal/chemical exposure tests were performed on the rigid candles. The Fibrosic material has the potential to be the next generation of hot gas filtration materials. The Fibrosic tubesheet was examined to see what the effects of operational load were on the tubesheet over time at operating temperature. 


\section{SECTION 3}

\section{TECHNICAL DISCUSSION}

\subsection{BACKGROUND}

There are two major types of ceramic filters currently under development for advanced coal utilization processes: ceramic candle filters and ceramic crossflow filters. The high-temperature filter systems in these processes typically operate at temperatures from $370^{\circ} \mathrm{C}\left(700^{\circ} \mathrm{F}\right)$ to $1,000^{\circ} \mathrm{C}$ $\left(1,830^{\circ} \mathrm{F}\right)$ and at pressures from 10 to $30 \mathrm{~atm}$. These processes may either be oxidizing or reducing; and the atmospheres contain alkali metals, carbon monoxide, sulfur, calcium, hydrogen, iron, and water vapor. This project focused on the investigation of ceramic candle filters only. Ceramic candle filters are rigid, tubular filters made by bonding ceramic fibers or grains, or a combination thereof. The most common forms of commercial candle filters for the applications of interest are composed of silicon carbide or alumina-silica grains held together with a clay binder.

A typical candle configuration consists of two porous layers. The outer filtration surface is a relatively dense thin layer with small pore openings. This surface layer is the primary filtration surface, and can be formed from small grains or fine fibers. This thin outer layer is supported by a thick, highly porous grain structure used mainly to impart overall strength (see Figure 3-1).

Pulse cleaning is used as the filter-cleaning mechanism for ceramic candle filter systems under operating conditions. Pulse cleaning is accomplished by a sharp pulse of high-pressure gas introduced into the individual candle via a manifold. The gas is usually delivered from the cleaning nozzle at near sonic velocity. Also, because of cost and material limitations, the pulse gas is not heated and is therefore, at about room temperature. In addition, because of the expansion across 


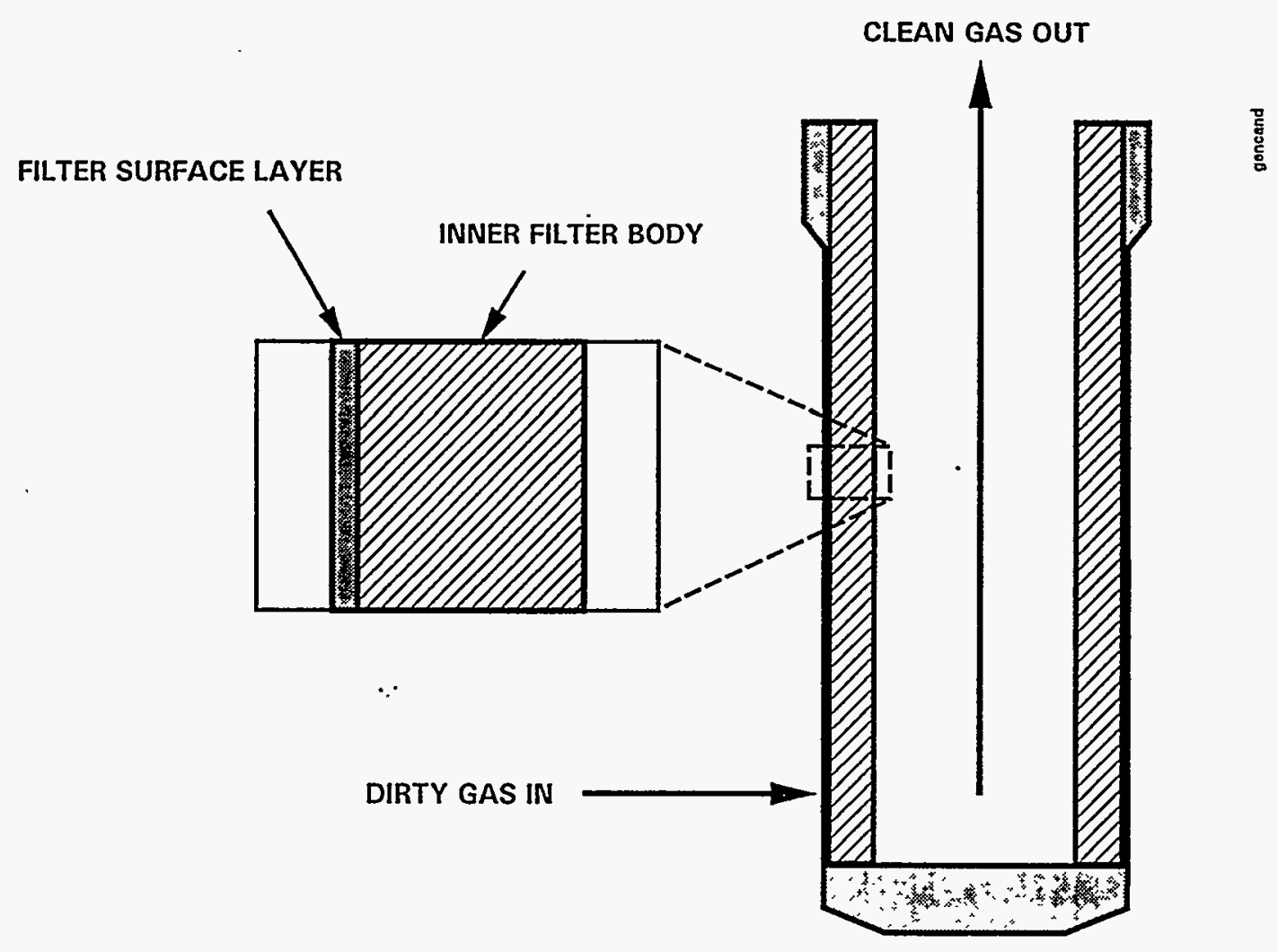

Figure 3-1. Ceramic Candle filter element

the nozzle, the pulse gas is adiabatically cooled. The relatively cold gas is introduced into the candle, which is at operating temperature (typically, $370^{\circ} \mathrm{C}$ to $1,000^{\circ} \mathrm{C}$ ).

Ceramic candle filters have been tested in a variety of PFBC and IGCC demonstration projects. In most of these demonstrations, the candles have failed during use. The failures have been caused primarily by thermal or mechanical shock. For example at the Grimethorpe PFBC ${ }^{2}$, ceramic filter candles failed twice. The first failure occurred when a pulse cleaning solenoid valve stuck open, dumping cold pulse air into a pulse cleaning manifold until the pulse reservoir pressure equaled the system pressure, thermally shocking the filter candles. In the second, separate failure, high face velocities created sufficient pressure drop to lift the candles from the tubesheet. The pressure released and the candles dropped back into the tubesheet, breaking some of the candles and damaging the flanges on many others. -

At KRW (refer to Appendix F), the same type of clay-bound silicon carbide (SiC) filter used at the Grimethorpe facility failed early in the testing because of thermal shock. A water quench 
upstream of the filter malfunctioned and ceased operation. The temperature of gas through the filter vessel rose rapidly to about $925^{\circ} \mathrm{C}\left(1,700^{\circ} \mathrm{F}\right)$. When the water quench was reinitiated, the filters broke immediately. In a second episode at KRW, filters broke when a slug of solids moved through the system and impacted the filters.

As a part of this project, Acurex Environmental analyzed selected ceramic candle filters which have been exposed at the KRW gasifier. The purpose was to determine if exposure had been detrimental to the strength and filtration properties of the candle filters. A copy of this report, entitled "Analysis of Candle Filters from the KRW Gasifier," is presented in Appendix F. This project attempted to investigate thermal and chemical degradation mechanisms that affects the life expectancy of ceramic candle filters.

\subsection{MATERIALS SELECTION}

The initial candle examined by Acurrex Environmental in this project was the Schumacher DiaSchumalith (Schumacher) F40. The Schumacher candle was being used at the American Electric Power Tidd PFBC Demonstration Project and were the most widely available candle filter at the time. The porous outer layer acts as the filtration surface and is made of a thin, relatively dense (wash coat) layer of alumino-silicate fibers in an alumino-silicate binder. The pore size of the filtration surface is approximately 15 to $30 \mu \mathrm{m}$. The outer membrane retains particulates greater than $0.1 \mu \mathrm{m}$ in diameter. The thick inner layer primarily supports the thin outer filtration layer of the candle and consists of a highly porous structure (pore size of $\approx 300$ to $500 \mu \mathrm{m}$ ).

Around mid-project, the Refractron 70/3 with 442-T binder candle was examined because it was a candidate for the next generation of candle filter design. The two-layered Refractron candles tested in this project had an outside diameter of $60 \mathrm{~mm}$ and a wall thickness of $10 \mathrm{~mm}$. The candle filters are made by bonding the silicon carbide (SiC) grains together with an aluminosilicate clay binder. The $9 \mathrm{~mm}$ inner supporting layer consists of a coarse $\mathrm{SiC}$ grain (grade 70). The thin $(1 \mathrm{~mm}$ ) outer filtration layer has a fine $\mathrm{SiC}$ grain (grade 3 ). Hence, the designation "70/3" is derived from the grades of the inner and outer $\mathrm{SiC}$ grains. 
The latter part of the project involved the preliminary assessment of Industrial Filter \& Pump's (IFP) fibrous filter and tubesheet (Fibrosic). The fibrous filter is different from the all the other rigid candles (typically $\mathrm{SiC}$ grains held together by an alumino-silicate binder) tested in this project. The filter is a vacuum-formed body which is post-treated to strengthen the high stress areas and modify the surface pore size. It is currently thought that fibrous candles have better thermal shock characteristics than rigid candles. Because of the unique way in which the fibrous candles are constructed, thermal stresses are not as great, probably due to low thermal expansion. The fibrous tubesheet was also examined for its structural integrity as a possible replacement for the standard metal tubesheet used in candle filter vessels.

The other candle materials examined in this project to a lesser extent than the above materials were the Refractron 50/5 with 505 binder, the IFP LayCer, and the Didier SiC20 candle. The Refractron $50 / 5$ with 505 binder candle has the same dimensions as the previously mentioned Refractron $70 / 3$ with $442-\mathrm{T}$ binder. The difference is that the Refractron $50 / 5$ with 505 binder candle has a 9-mm inner supporting layer which consists of grade $50 \mathrm{SiC}$ grains and the thin 1-mm outer filtration layer of grade 5 SiC grains. The IFP LayCer candle has the same dimensions and grain sizes as the Refractron 50/5 with 505 binder candle because IFP was initially marketing this candle under the name of LayCer. The Didier SiC20 candle is a homogeneous single layer candle that does not have two separate layers (one for filtration and one for structural support). The Didier candle is made up of $\mathrm{SiC}$ grains of grade 20 throughout the whole candle.

\subsection{TEST PROCEDURES}

\subsubsection{Long-Term Thermal Exposure Tests}

Porous ceramic candle filter material degradation may be caused by several factors working in combination. Pulse cleaning with room-temperature gas may cause temperature drops in the filter sufficient to cause alkali vapor to condense in the porous filter as well as thermally shocking/fatiguing the candle. The alkali deposition may provide areas for alkali/ceramic reactions to occur, leading to weakening of the filter material. Thermal shock may induce micro-cracking that 
reduces the material strength. The purpose of the long-term exposure testing is to provide data on the synergistic or antagonistic effects on candle filter materials of long term exposure to temperature, alkali vapor, steam, and pulse cleaning.

Schumacher Diaschumalith and Refractron 70/3 with 442-T binder candles were tested under the following atmospheric conditions:

- $20 / 65 / 95 \mathrm{ppm} \mathrm{NaCl}$ (by volume)

- $15 / 20 \%$ steam (by volume)

- Atmospheric pressure

- $870^{\circ} \mathrm{C} / 980^{\circ} \mathrm{C}\left(1,600^{\circ} \mathrm{F} / 1,800^{\circ} \mathrm{F}\right)$

- With/without pulse cleaning

- $100 / 400 / 500 / 1,000$ hours of exposure

The pulse cleaned candles were exposed to pulse cleaning durations of 0.5 seconds. The pulse cleaning gas enters the candles through a quarter inch tube which is attached to a solenoid valve with a pressure reservoir (set at $80 \mathrm{psig}$ ) on the other side. The levels of alkali tested at atmospheric pressure simulate the operating alkali concentrations of 2 to $10 \mathrm{ppm}$ at 10 atmospheres.

The candle face velocities ranged between 8 to $17 \mathrm{ft} / \mathrm{min}$. Table 3-1 lists the different combinations tested and the letter designation used for identification in this report.

Tests A and B were conducted in the original exposure vessel made of RA 330. About midway through tests $C$ and D, the RA 330 exposure vessel failed. The remainder of tests C and D were conducted in a stainless steel vessel. Tests $\mathrm{E}$ through $\mathrm{M}$ (all at $870^{\circ} \mathrm{C}$ ) were also conducted in a stainless steel vessel. Tests $\mathrm{N}$ through $\mathrm{Q}$ were conducted in a Haynes 556 (a corrosion resistant superalloy) vessel. Figure 3-2 is an assembly drawing of the Haynes 556 vessel. Not shown in the figure is the alumina liner (tube) that was inserted inside the exposure vessel to minimize alkali corrosion of the superalloy. This also minimized vessel corrosion by-products from being deposited on the candle specimens. On Figure 3-2, the gas entered from the left side of the drawing and the gas exited out the right side. All of the design drawings for the Haynes 556 exposure vessel are 
Table 3-1. Thermal exposure test conditions

\begin{tabular}{|c|c|c|c|c|c|}
\hline Test & Pulse Cleaning & $\begin{array}{c}\mathrm{NaCl} \text { Concentration } \\
(\mathrm{ppm})\end{array}$ & $\begin{array}{l}\text { Steam } \\
(\%)\end{array}$ & $\begin{array}{l}\text { Temperature } \\
\left({ }^{\circ} \mathrm{C}\right)\end{array}$ & $\begin{array}{c}\text { Exposure } \\
\text { (hours) }\end{array}$ \\
\hline & \multicolumn{4}{|c|}{ SCHUMACHER DIASCHUMALITH F40 CANDLE } & \\
\hline A & No & 95 & 20 & 870 & 100 \\
\hline B & Yes & 65 & 20 & 980 & 100 \\
\hline $\mathrm{C}$ & Yes & 65 & 20 & 980 & 475 \\
\hline $\mathrm{D}$ & Yes & 65 & 20 & 980 & 575 \\
\hline $\mathrm{E}$ & Yes & 20 & 15 & 870 & 100 \\
\hline $\mathrm{F}$ & Yes & 20 & 15 & 870 & 400 \\
\hline$G$ & Yes & 20 & 15 & 870 & 500 \\
\hline \multirow[t]{2}{*}{$\mathrm{H}$} & Yes & 20 & 15 & 870 & 1,000 \\
\hline & \multicolumn{4}{|c|}{ REFRACTRON 70/3 WITH 442-T BINDER CANDLE } & \\
\hline I & No & 20 & 15 & 870 & 100 \\
\hline $\mathbf{J}$ & Yes & 20 & 15 & 870 & 100 \\
\hline $\mathrm{K}$ & Yes & 20 & 15 & 870 & 400 \\
\hline $\mathrm{L}$ & Yes & 20 & 15 & 870 & 500 \\
\hline M & Yes & 20 & 15 & 870 & 1,000 \\
\hline$N$ & Yes & 20 & 15 & 980 & 100 \\
\hline 0 & Yes & 20 & 15 & 980 & 400 \\
\hline $\mathbf{P}$ & Yes & 20 & 15 & 980 & 500 \\
\hline$Q$ & Yes & 20 & 15 & 980 & 1,000 \\
\hline
\end{tabular}




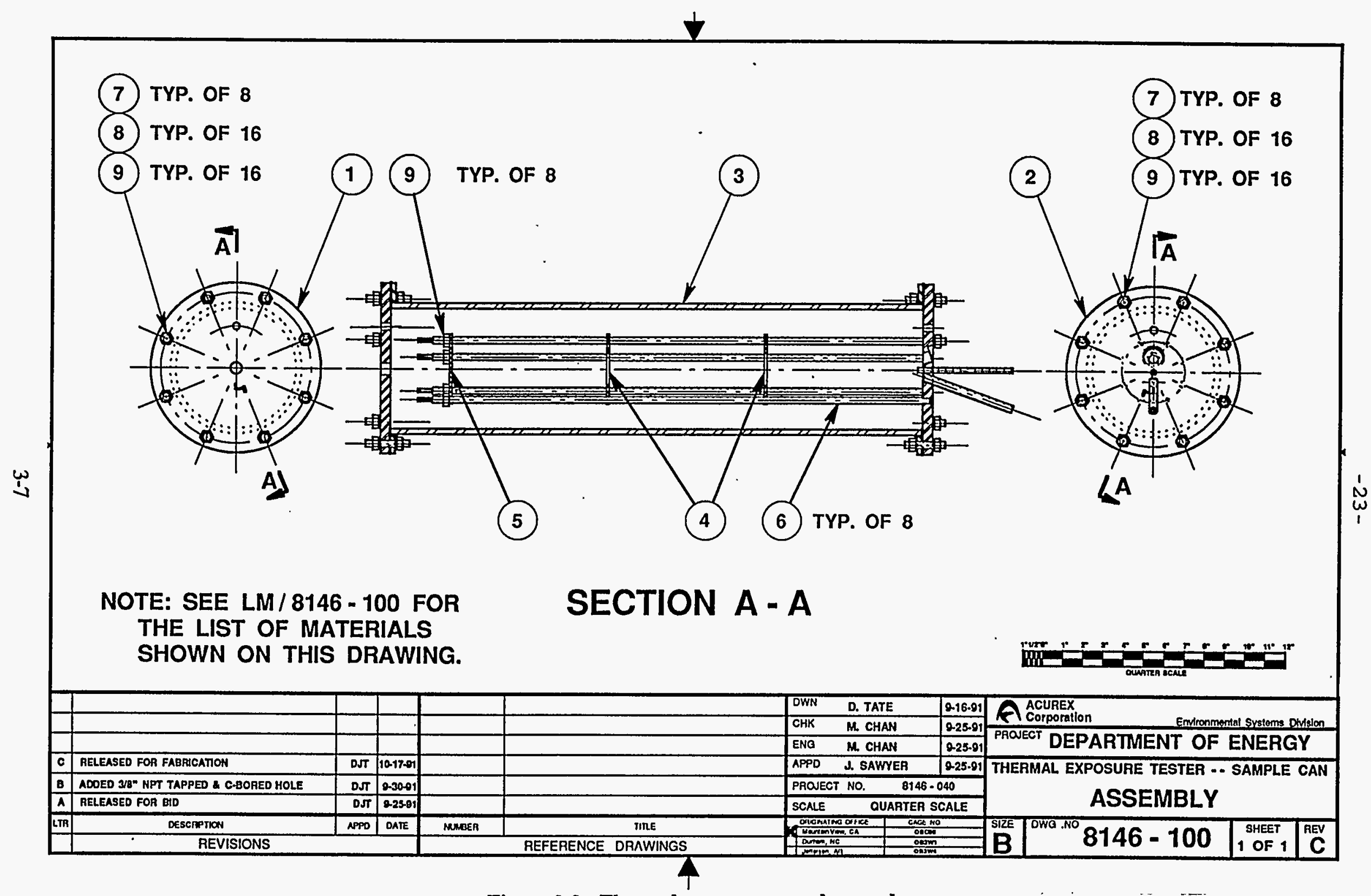

Figure 3-2. Thermal exposure sample vessel 
included in appendix A. The RA 330 and stainless steel vessels were similar to the Haynes 556 exposure vessel except they were smaller, had no alumina liner, and only had flanges on the exit side of the vessel.

The Acurex Environmental thermal exposure system was designed to accommodate the running of two exposure vessels simultaneously. Figure 3-3 is the schematic of the dual hightemperature flow-through exposure test system. The design allowed the two exposure processes to operate with sufficient independence that if one of the processes had to be shut down, the other exposure process/test could continue running. Both systems shared the same air supply, air preheat ("A" system in Figure 3-3), and pulse cleaning system. This sharing lowered space and cost requirements.

The "B" system pertains to the stainless steel exposure vessel (which is inside the B-3 heater), and the " $\mathrm{Cl}$ system denotes components of the Haynes exposure vessel (which is inside the C-3 heater). The B-x and C-x designations are clam shell heaters for the respective exposure processes/systems that heat up the gas lines and the exposure vessels. The only critical components that could shut down both processes at the same time are the air supply, the electrical power supply, the " $\mathrm{A}$ " system, the pulse vessel, or the timer for the pulse cleaning system.

In the C-system, the alkali was designed to be injected into C-2. This design was feasible due the size of the Haynes exposure vessel (it is twice the length of the B-system vessel) and the two heated sections (A-1 and C-1) that preheated the air which enabled the alkali solution to vaporize.

In the B-system, the alkali was injected into B-1 which is heated and then mixed with preheated air from A-1. The mixture was then heated some more by B-2 before entering the exposure vessel in B-3. The B-system design was deemed undesirable due to alkali deposition onto the inner walls of the lines leading into the exposure vessel, which sometimes resulted in tests shutting down due to blockages of the line. Alkali deposition was not constant nor predictable 


\section{THERMAL EXPOSURE SYSTEM}

$\omega$

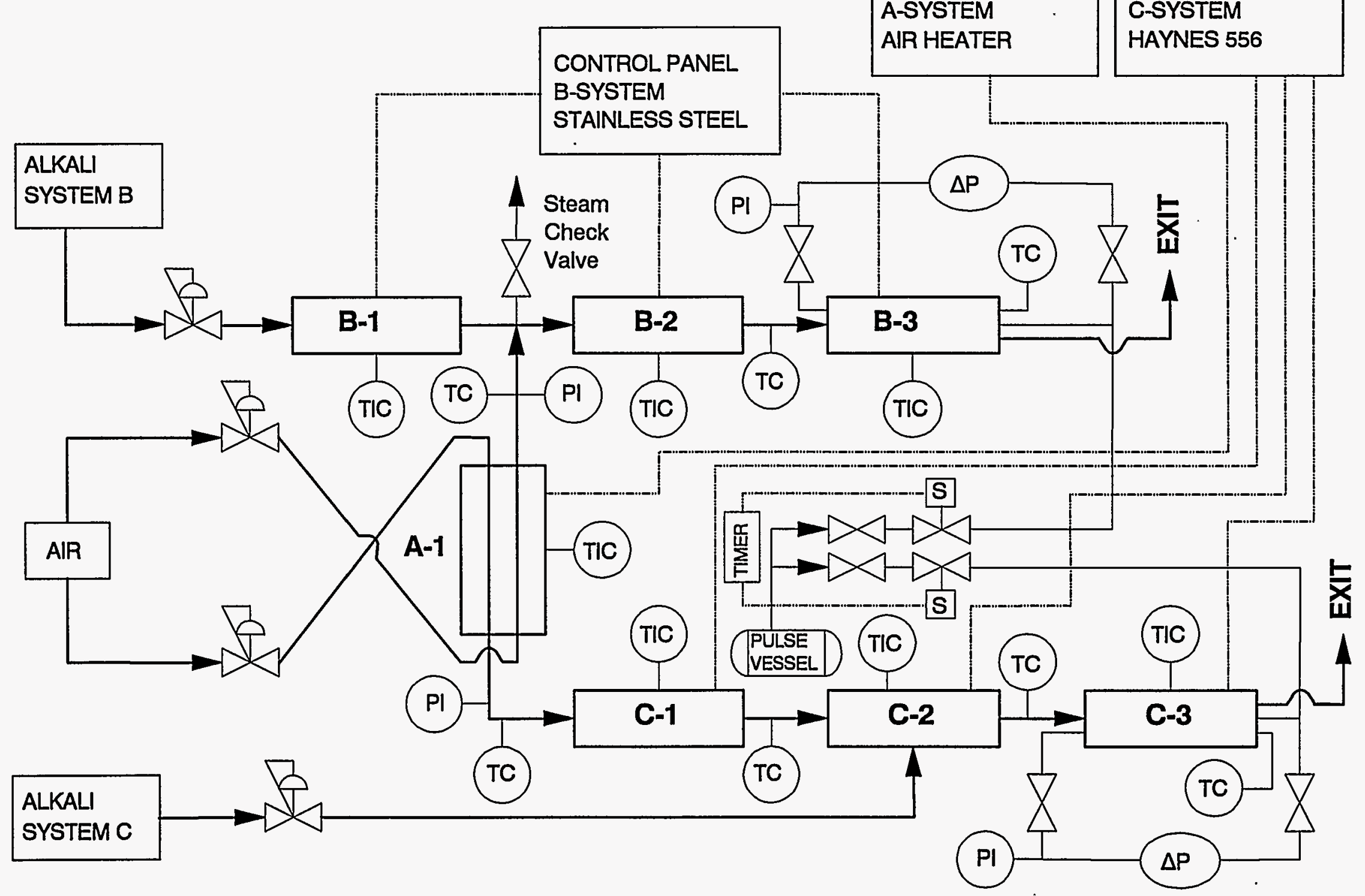

Figure 3-3. Schematic of dual flow-through thermal exposure system 
because the process lines (and connectors) were stainless steel that exhibited scaling and becoming embrittled due to the alkali, steam and temperatures.

The C-system minimized alkali deposition into the process line by injecting the alkali solution into the pipe in a heater just prior to the exposure vessel, thereby reducing the length of the process line exposed to the alkali. The two heaters (A-1 and C-1) also helped by preheating the air close to the test temperature before even coming in contact with the alkali solution. There were no shut downs attributed to alkali blockage of the lines leading to the exposure vessel.

The methodology for exchanging samples consisted of putting the 1,000-hr specimen into the exposure vessel with the $100-\mathrm{hr}$ specimen. After 100 hours of exposure, the 100-hr specimen was replaced with the 500-hr specimen (leaving the 1,000-hr specimen in the vessel). After 500 hours of exposure, the 500-hr specimen was replaced with a 400-hr specimen (the 1,000-hr specimen still remaining inside the vessel). After 400 more hours of exposure, the 1,000-hr specimen had accumulated about 1,000 hours of exposure. The 1,000-hr specimen was situated in the back of the vessel near the gas exit of the vessel, and the other specimens (100-hr, 500-hr, and 400-hr) were butted against the front of the $1,000-\mathrm{hr}$ specimen which was nearer to the gas entrance into the vessel. Figure 3-4 shows the placement of the candle specimens inside the exposure vessel.

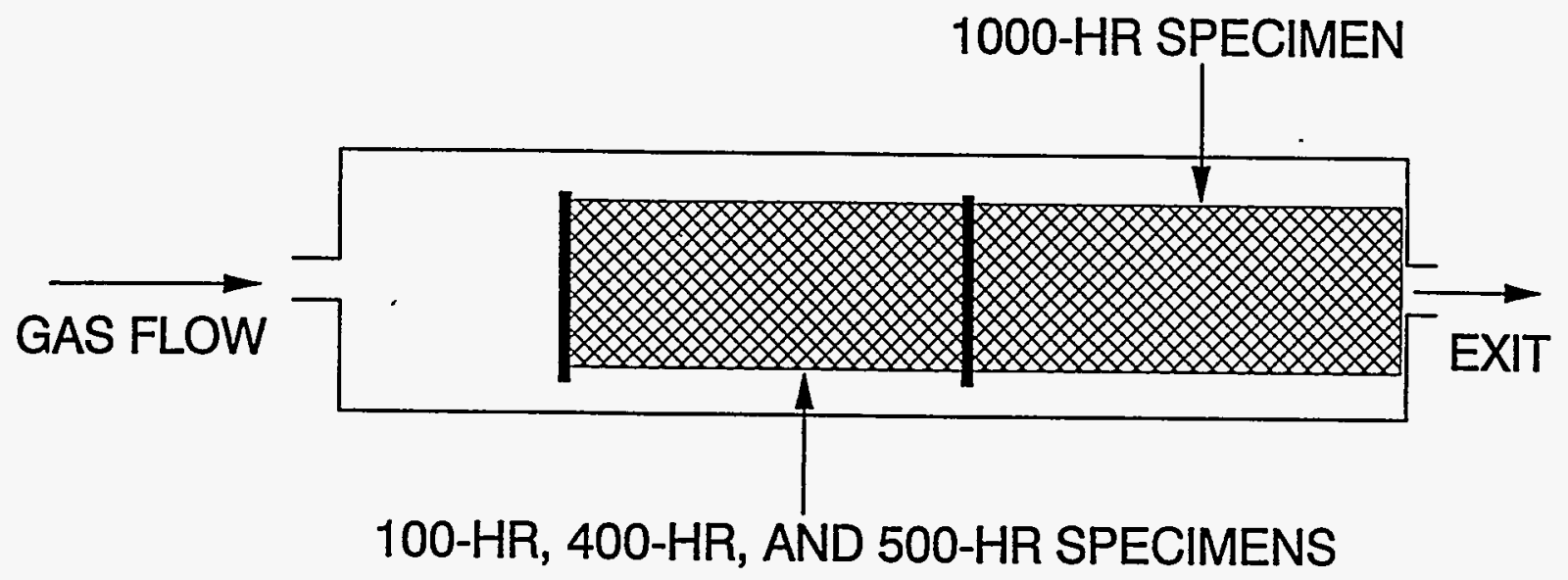

Figure 3-4. Candle specimen placement inside the exposure vessel 
The pulse cleaning system pulsed ambient air into the bore of the candle specimens approximately every 30 minutes during testing. The duration of each pulse is 0.5 seconds. Table 3-2 summarizes the approximate total pulse cleaning history of each candle specimen.

If the system ran perfectly, the number of pulses for each test would be double the number of hours tested because the system was pulsed every half hour. However, due to problems such as heater failures, blockage of alkali injection orifices, process line failures, and drops in alkali flow, the process down times were deducted from the cumulative exposure times. Therefore, the actual cumulative hours that the system was running are greater than the cumulative exposure times.

The alkali system for each process system (B or $\mathrm{C}$ in Figure 3-3) consisted of a dual pressurized reservoir for the $\mathrm{NaCl} /$ water mixture. The alkali solution was injected through a 0.005 inch orifice into the respective process system. The dual alkali reservoir system for each process allowed for continuous operation whereby the depressurization and filling of alkali solution into one reservoir could be accomplished while the other pressurized reservoir continued alkali injection.

Problems due to high temperature operation and obstruction of the alkali injection orifice caused delays in the beginning months of thermal exposure testing with the Schumacher Diaschumalith F40 candles. Figure 3-5 shows the cumulative hours of exposure at the stated conditions for the Schumacher candles and a Refractron 50/5 with 505 binder candle. The 65 ppm $\mathrm{NaCl}$ exposure testing condition was aborted because the level of $\mathrm{NaCl}$ was deemed to be excessive. The process line and exposure vessel failed prematurely. The testing of the Refractron 50/5 with 505 binder candle was aborted because the testing of the Refractron 70/3 with 442-T binder candle was considered more appropriate. At the time, the Refractron $50 / 5$ candle was no longer going to be available commercially. Figure 3-6 shows the cumulative hours tested for the Refractron 70/3 with 442-T binder candles under the stated conditions. It can be seen in Figure 3-6 that the stainless steel system [operating at $870^{\circ} \mathrm{C}\left(1,600^{\circ} \mathrm{F}\right)$ ] was running concurrently with the Haynes system [operating at $980^{\circ} \mathrm{C}\left(1,800^{\circ} \mathrm{F}\right)$ ] and when one system was down, the other system was able to continue testing unaffected. 
Table 3-2. Pulse cleaning history

\begin{tabular}{|c|c|c|c|}
\hline Test & $\begin{array}{c}\text { Pulse } \\
\text { Cleaning }\end{array}$ & Test Description/Condition & $\begin{array}{l}\text { Total } \\
\text { Pulses }\end{array}$ \\
\hline & \multicolumn{2}{|c|}{ SCHUMACHER DIASCHUMALITH F40 } & \\
\hline A & No & $95 \mathrm{ppm} \mathrm{NaCl} / 20 \% \mathrm{H}_{2} \mathrm{O} / 870^{\circ} \mathrm{C} / 100 \mathrm{hrs}$ & 0 \\
\hline B & Yes & $65 \mathrm{ppm} \mathrm{NaCl} / 20 \% \mathrm{H}_{2} \mathrm{O} / 980^{\circ} \mathrm{C} / 100 \mathrm{hrs}$ & 200 \\
\hline $\mathrm{C}$ & Yes & $65 \mathrm{ppm} \mathrm{NaCl} / 20 \% \mathrm{H}_{2} \mathrm{O} / 980^{\circ} \mathrm{C} / 475 \mathrm{hrs}$ & 1,050 \\
\hline $\mathrm{D}$ & Yes & $65 \mathrm{ppm} \mathrm{NaCl} / 20 \% \mathrm{H}_{2} \mathrm{O} / 980^{\circ} \mathrm{C} / 575 \mathrm{hrs}$ & 1,250 \\
\hline $\mathrm{E}$ & Yes & $20 \mathrm{ppm} \mathrm{NaCl} / 15 \% \mathrm{H}_{2} \mathrm{O} / 870^{\circ} \mathrm{C} / 100 \mathrm{hrs}$ & 230 \\
\hline F & Yes & $20 \mathrm{ppm} \mathrm{NaCl} / 15 \% \mathrm{H}_{2} \mathrm{O} / 870^{\circ} \mathrm{C} / 400 \mathrm{hrs}$ & 920 \\
\hline G & Yess & $20 \mathrm{ppm} \mathrm{NaCl} / 15 \% \mathrm{H}_{2} \mathrm{O} / 870^{\circ} \mathrm{C} / 500 \mathrm{hrs}$ & 1,140 \\
\hline $\mathrm{H}$ & Yes & $20 \mathrm{ppm} \mathrm{NaCl} / 15 \% \mathrm{H}_{2} \mathrm{O} / 870^{\circ} \mathrm{C} / 1,000 \mathrm{hrs}$ & 2,290 \\
\hline & \multicolumn{2}{|c|}{ REFRACTRON 70/3 WITH 442-T BINDER } & \\
\hline I & No & $20 \mathrm{ppm} \mathrm{NaCl} / 15 \% \mathrm{H}_{2} \mathrm{O} / 870^{\circ} \mathrm{C} / 100 \mathrm{hrs}$ & 0 \\
\hline $\mathrm{J}$ & Yes & $20 \mathrm{ppm} \mathrm{NaCl} / 15 \% \mathrm{H}_{2} \mathrm{O} / 870^{\circ} \mathrm{C} / 100 \mathrm{hrs}$ & 240 \\
\hline $\mathrm{K}$ & Yes & $20 \mathrm{ppm} \mathrm{NaCl} / 15 \% \mathrm{H}_{2} \mathrm{O} / 870^{\circ} \mathrm{C} / 400 \mathrm{hrs}$ & 980 \\
\hline $\mathrm{L}$ & Yes & $20 \mathrm{ppm} \mathrm{NaCl} / 15 \% \mathrm{H}_{2} \mathrm{O} / 870^{\circ} \mathrm{C} / 500 \mathrm{hrs}$ & 1,170 \\
\hline M & Yes & $20 \mathrm{ppm} \mathrm{NaCl} / 15 \% \mathrm{H}_{2} \mathrm{O} / 870^{\circ} \mathrm{C} / 1,000 \mathrm{hrs}$ & 2,390 \\
\hline $\mathbf{N}$ & Yes & $20 \mathrm{ppm} \mathrm{NaCl} / 15 \% \mathrm{H}_{2} \mathrm{O} / 980^{\circ} \mathrm{C} / 100 \mathrm{hrs}$ & 230 \\
\hline $\mathrm{O}$ & Yes & $20 \mathrm{ppm} \mathrm{NaCl} / 15 \% \mathrm{H}_{2} \mathrm{O} / 980^{\circ} \mathrm{C} / 400 \mathrm{hrs}$ & 840 \\
\hline $\mathbf{P}$ & Yes & $20 \mathrm{ppm} \mathrm{NaCl} / 15 \% \mathrm{H}_{2} \mathrm{O} / 980^{\circ} \mathrm{C} / 500 \mathrm{hrs}$ & 1,060 \\
\hline Q & Yes & $20 \mathrm{ppm} \mathrm{NaCl} / 15 \% \mathrm{H}_{2} \mathrm{O} / 980^{\circ} \mathrm{C} / 1,000 \mathrm{hrs}$ & 2,130 \\
\hline
\end{tabular}




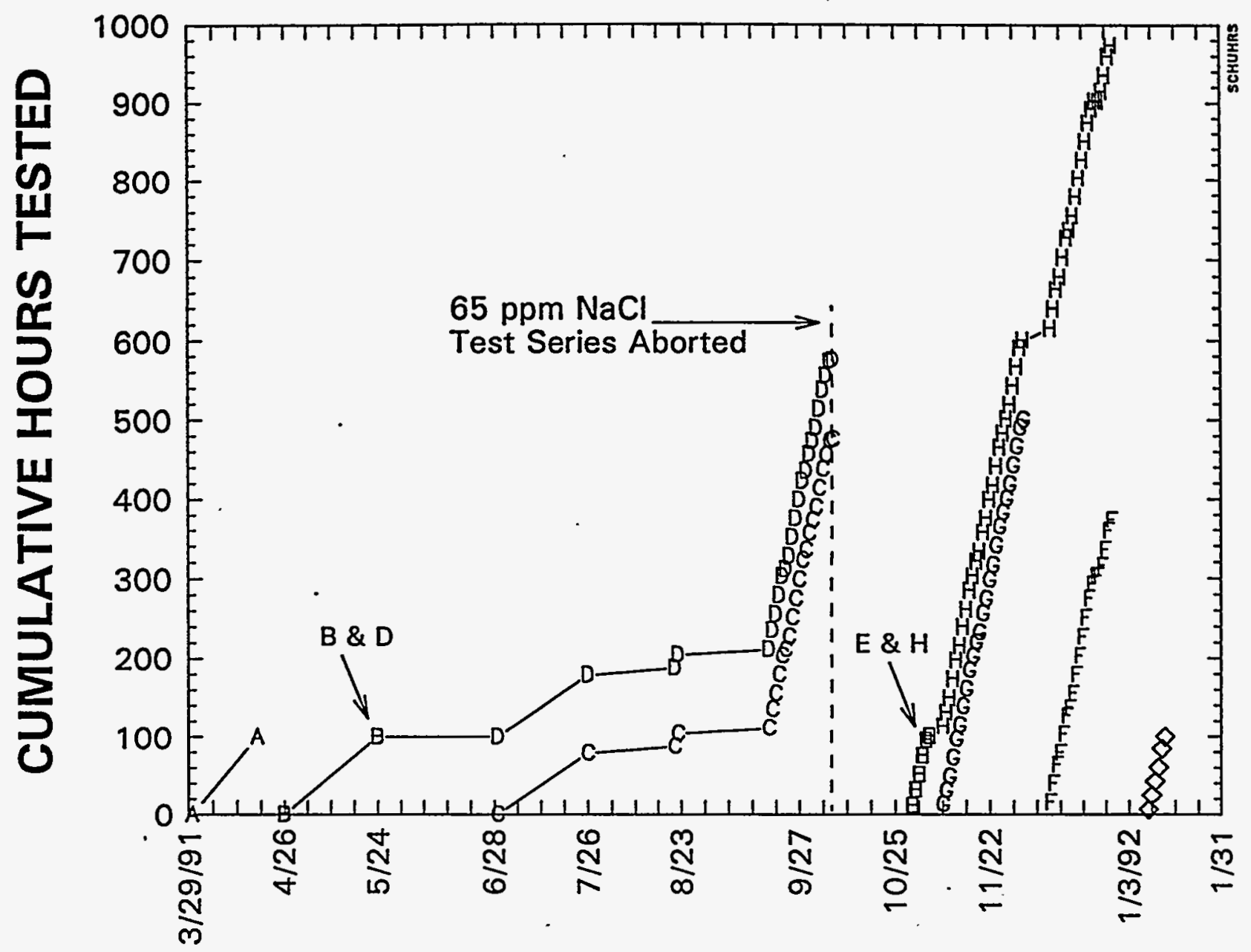

FISCAL MONTH END DATE

Schumacher Dia-Schumalith

A 100 -hr Test at $870^{\circ} \mathrm{C}, 20 \%$ Steam, and $95 \mathrm{ppm} \mathrm{NaCl}$

B 100-hr Test at $980^{\circ} \mathrm{C}, 20 \%$ Steam, and $65 \mathrm{ppm} \mathrm{NaCl}$

C 500-hr Test at $980^{\circ} \mathrm{C}, 20 \%$ Steam, and $65 \mathrm{ppm} \mathrm{NaCl}(475-\mathrm{hr})$

D 1,000-hr Test at $980^{\circ} \mathrm{C}, 20 \%$ Steam, and $65 \mathrm{ppm} \mathrm{NaCl}(575-\mathrm{hr})$

E $100-$ hr Test at $870^{\circ} \mathrm{C}, 15 \%$ Steam, and $20 \mathrm{ppm} \mathrm{NaCl}$

F 400 -hr Test at $870^{\circ} \mathrm{C}, 15 \%$ Steam, and $20 \mathrm{ppm} \mathrm{NaCl}$

G $500-\mathrm{hr}$ Test at $870^{\circ} \mathrm{C}, 15 \%$ Steam, and $20 \mathrm{ppm} \mathrm{NaCl}$

H 1,000-hr Test at $870^{\circ} \mathrm{C}, 15 \%$ Steam, and $20 \mathrm{ppm} \mathrm{NaCl}$

Refractron 50/5 with 505 binder

$\diamond 100$-hr Test at $870^{\circ} \mathrm{C}, 15 \%$ Steam, and $20 \mathrm{ppm} \mathrm{NaCl}$

*No Pulse Cleaning

Figure 3-5. Graph of the cumulative thermal exposure system up-time for Schumacher candle specimens 


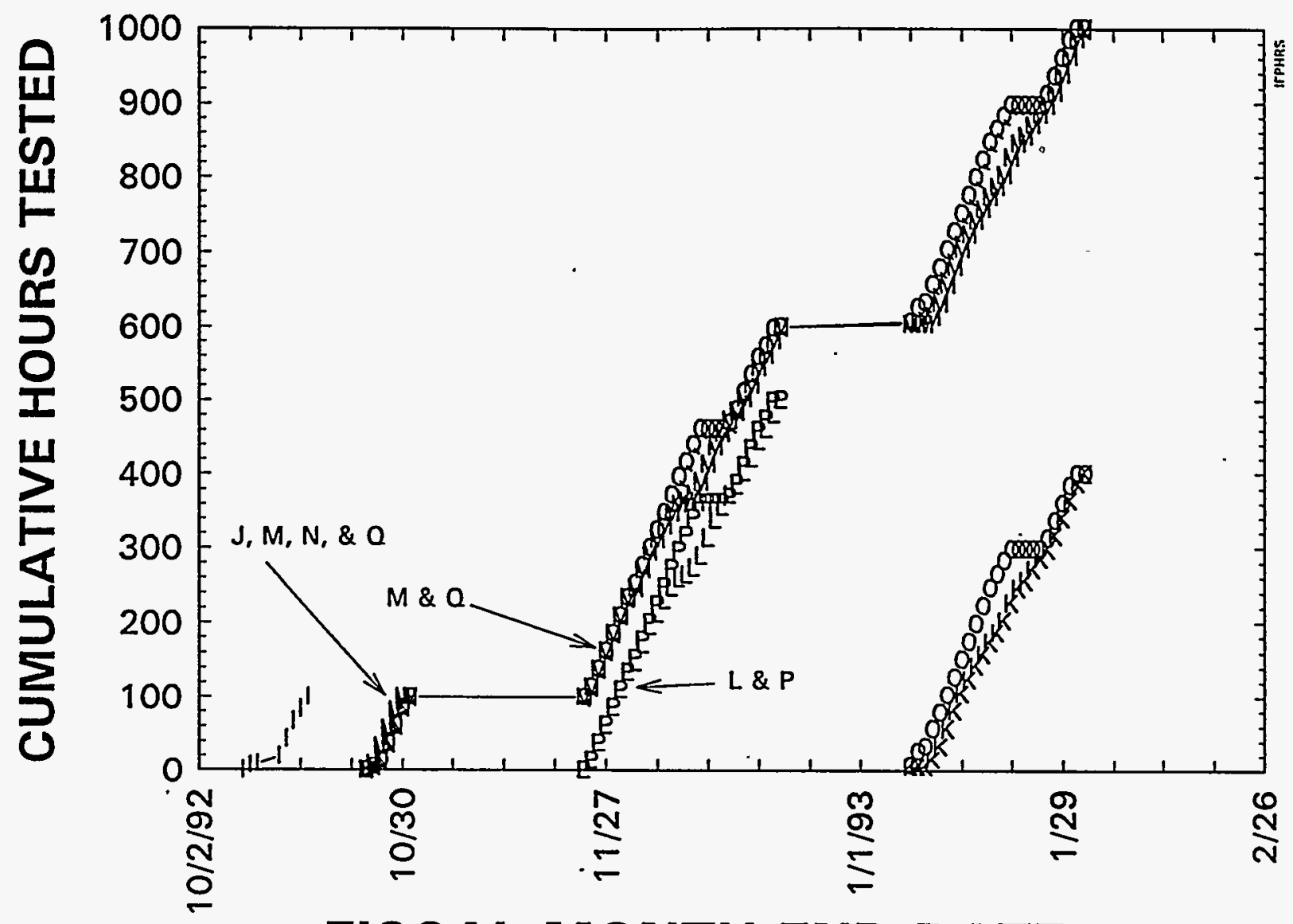

FISCAL MONTH END DATE

REFRACTRON 70/3 with 442-T binder

I 100-hr Test at $870^{\circ} \mathrm{C}, 15 \%$ Steam, and $20 \mathrm{ppm} \mathrm{NaCl}$

$\mathrm{J} 100-\mathrm{hr}$ Test at $870^{\circ} \mathrm{C}, 15 \%$ Steam, and $20 \mathrm{ppm} \mathrm{NaCl}$

$\mathrm{K}$ 400-hr Test at $870^{\circ} \mathrm{C}, 15 \%$ Steam, and $20 \mathrm{ppm} \mathrm{NaCl}$

L 500-hr Test at $870^{\circ} \mathrm{C}, 15 \%$ Steam, and $20 \mathrm{ppm} \mathrm{NaCl}$

$M$ 1,000-hr Test at $870^{\circ} \mathrm{C}, 15 \%$ Steam, and $20 \mathrm{ppm} \mathrm{NaCl}$

$\mathrm{N}$ 100-hr Test at $980^{\circ} \mathrm{C}, 15 \%$ Steam, and $20 \mathrm{ppm} \mathrm{NaCl}$

0 400-hr Test at $980^{\circ} \mathrm{C}, 15 \%$ Steam, and $20 \mathrm{ppm} \mathrm{NaCl}$

P 500-hr Test at $980^{\circ} \mathrm{C}, 15 \%$ Steam, and $20 \mathrm{ppm} \mathrm{NaCl}$

Q $1,000-$ hr Test at $980^{\circ} \mathrm{C}, 15 \%$ Steam, and $20 \mathrm{ppm} \mathrm{NaCl}$

"No Pulse Cleaning

Figure 3-6. Graph of the cumulative thermal exposure system up-time for Refractron 70/3 with 442-T binder candle specimens 
In order to track the operation of the exposure system overnight while still running, a data acquisition system (DAS) was implemented near the end of the exposure testing series. The DAS allowed for an estimate of the time when a problem occurred (such as when a heater failed) in order to adjust the cumulative time of exposure correctly. Figures 3-7 and 3-8 are examples of the temperature data obtained from the data acquisition system of the stainless steel system (B-system) and the Haynes system (C-system) respectively. The B-system is smaller and was therefore harder to keep at a steady temperature (as evident in Figure 3-7). The C-system was larger and therefore had a larger thermal mass to help keep the temperatures steady (see Figure 3-8). From examining the data in Figures 3-7 and 3-8, it appears the gas temperature in the rear of the vessel was lower than the gas temperature in the front of the vessel and inside the candle. The difference in temperature was about $100^{\circ} \mathrm{C}$. This would imply that the outside surface of the $1,000-\mathrm{hr}$ candle specimens (which is situated at the rear of both vessels) was not at the desired temperature, but the 100-hr, 400-hr, 500-hr candle specimens, and the inside surfaces of all the candles were at the desired temperatures. A possible cause for the differences in temperatures is that the large flanges at the ends of the vessels were at a much cooler temperature (although they are insulated by fibrous board and blanket insulation) than the body of the vessel because the flanges are not directly heated (only the cylindrical body of the vessel is directly heated by the heaters).

\subsubsection{C-Ring Testing}

The conventional methods of mechanical strength measurement/testing of candles are uniaxial tension or compression tests, burst tests, and three or four point bend tests. Burst tests, which entail the use of a bladder in the bore of the candle, are not easily performed at elevated temperature. Uniaxial tension or compression and flexural tests require the machining of the candles into specimen shapes such that the original exposed surfaces (outer filtration surface and the inner bore surface) will no longer be present. For example, flexural tests require a rectangular bar-shaped specimen that is cut longitudinally from the candle and then machined leaving parallel opposing faces. If one wishes to study the operational performance taking into account the different 


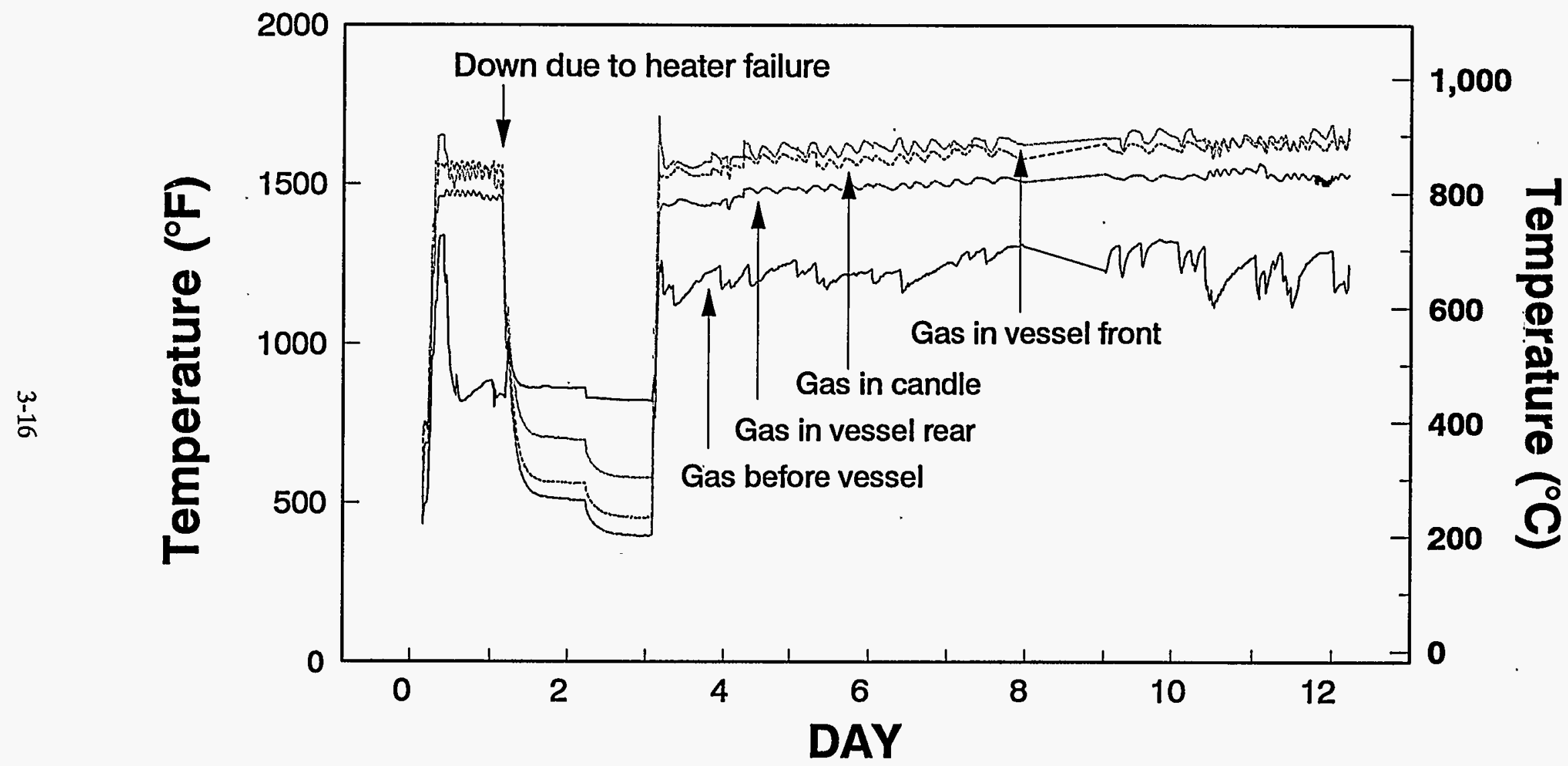

Figure 3-7. Temperature measurements from the data acquisition system of a $870^{\circ} \mathrm{C}$ exposure test in the stainless steel ("B") system 


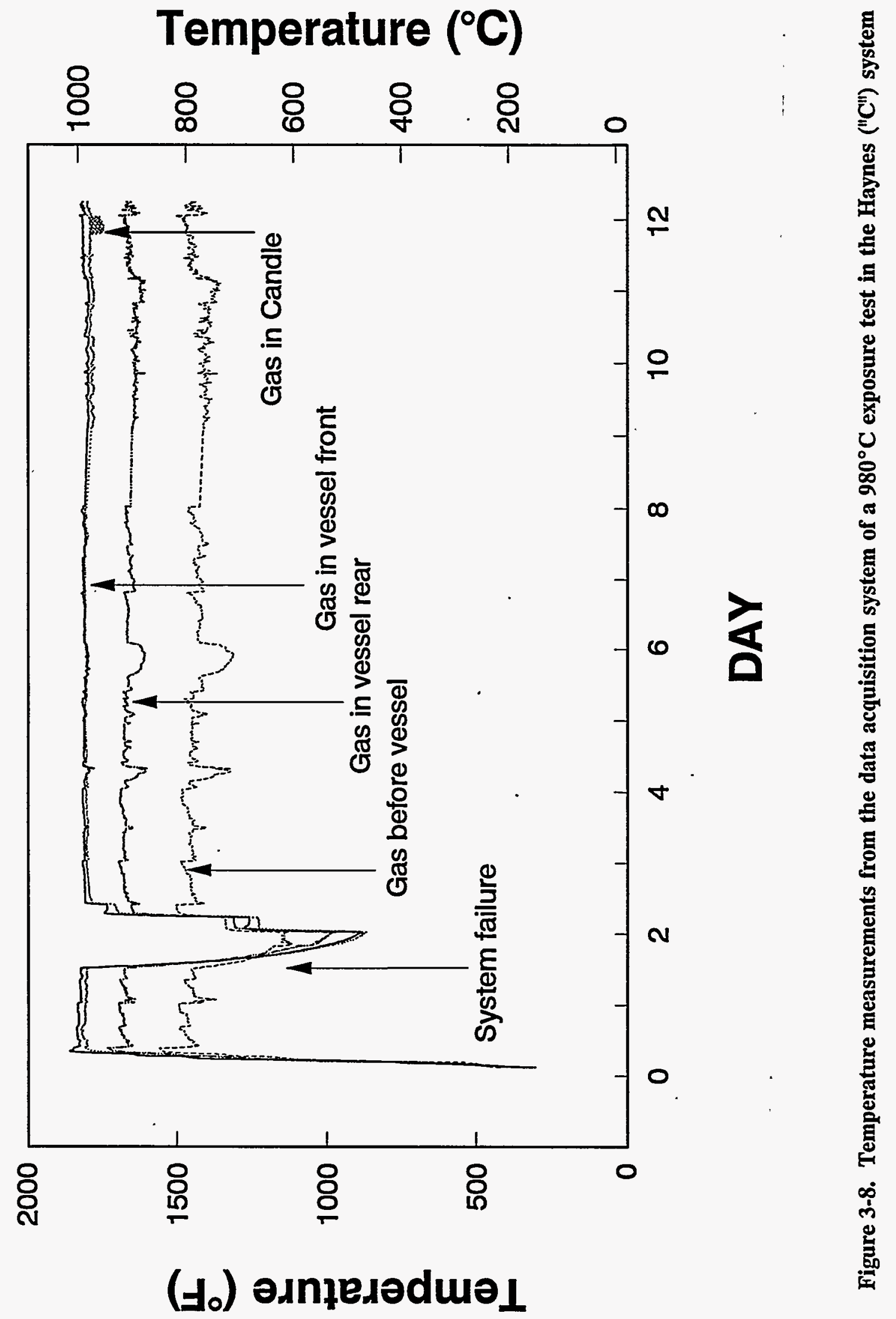


surfaces of the candle that are exposed to environmental conditions, then conventional uniaxial and flexural tests cannot be used.

C-ring testing is the preferred testing method because the specimens retain the surface flaw population. The ability to test the outer surface (via compression testing) or inner surface (via tension testing) independently helps to eliminate variables that may influence the results. The equipment required to perform c-ring testing allows for easy insertion into a clam shell furnace which permits high temperature testing to more closely simulate operational temperatures.

C-ring testing was selected to be the major mechanical strength testing method to be used for this study. C-rings were obtained by sectioning rings out of the candles and then making a longitudinal slit (perpendicular to the sectioning direction) on one side of the ring (see Figure 3-9). C-ring testing is an excellent method because it leaves the surfaces of the candle (inner bore and the outer surface of the tube) intact and therefore the surface flaw population remains intact.

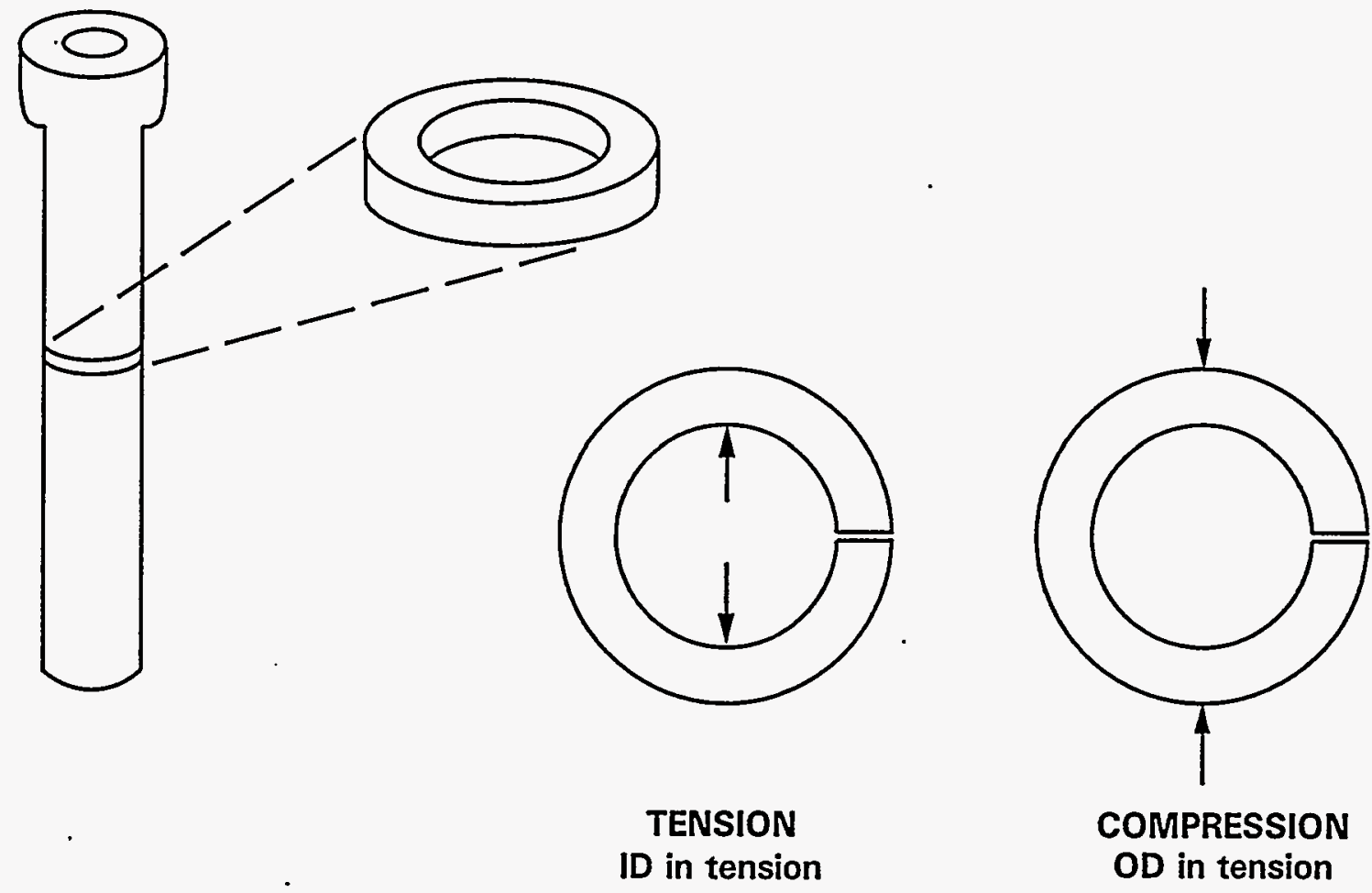

Figure 3-9. C-ring specimens from a ceramic candle 
C-ring preparation requires minimal machining, thus reducing the sample preparation costs. The selection of multiple specimens from specific positions of the candles and for specific test conditions is easy to accomplish using the c-ring specimen design.

Figure 3-9 also shows how the c-ring specimens loaded (indicated by the arrows). In tension, the inner surface of the candle at a point opposite the slit experiencing the maximum tensile stress; the outer surface experiencing the maximum compressive stress. In compression, the outside surface (opposite the slit) is bearing the maximum tensile stress. When compared to tensile strength, ceramics are much stronger under compressive stresses, therefore, failure/fracture of the c-ring will originate at the surface with the maximum tensile stress. This phenomenon allows focussing on a surface (inner or outer) to investigate its strength degradation from different environmental conditions. The areas of interest (opposite the slit in the c-ring) are the inner surface for c-ring tension testing $\left(R=R_{1}\right)$ and the outer surface for c-ring compression testing $\left(\mathrm{R}=\mathrm{R}_{2}\right) \cdot$

In order to validate the equation used for c-ring maximum stress calculations, Acurex Environmental examined the derivation of the equation (M. Ferber) ${ }^{3}$. Errors were discovered in a 1988 report by National Physical Laboratory (United Kingdom). ${ }^{4}$ The equations from M. Ferber, NPL (corrected), and Mark's Standard Handbook for Mechanical Engineers ${ }^{5}$ were found to be in agreement. The conclusion is that the correct expression for stress, after being simplified, is

$$
\sigma=\frac{F T}{2 W R\left[\frac{\left(R_{1}+R_{2}\right) \ln \left(R_{2} / R_{1}\right)}{2}-T\right]} \text {, }
$$

Where,

$$
\begin{aligned}
& \sigma=\text { maximum stress } \\
& \mathrm{F}=\text { maximum load } \\
& \mathrm{R}=\mathrm{R}_{1} \text { for tensile loading of c-ring (tension tests) }
\end{aligned}
$$


$\mathrm{R}=\mathrm{R}_{1}$ for tensile loading of c-ring (tension tests)

$\mathrm{R}_{2}$ for compressive loading of c-ring (compression tests)

$R_{1}=$ Inside radius of c-ring

$\mathrm{R}_{2}=$ Outside radius of $\mathrm{c}$-ring

$\mathrm{W}=$ width/thickness of $\mathrm{c}$-ring

$T=R_{2}-R_{1}$

The above equation is to calculate the maximum tensile stresses endured by the inner or outer surface of the candle (depending upon c-ring tension or compression testing) opposite the slit (see Figure 3-9). The original equation included a $" \cos \theta "$ term (see Appendix $C$ ) that allowed for the calculation of stresses in other areas of the c-ring specimen between the two points in which the load is applied. The angle $\theta$ is measured from the horizontal opposite the c-ring slit. The maximum stress (for both c-ring tension and compression tests) occurs at the angle $\theta$ of $0^{\circ}$. Any angle other than $0^{\circ}$ would result in smaller stress values and would not be at the site in which the c-ring would be experiencing the highest stress. Since the purpose of c-ring testing is to measure the maximum stress experienced by the specimen in order to ascertain the material strength, the angles other than $0^{\circ}$ are of no interest.

The standard deviation equation used for each sample set is defined as follows:

$$
s=\sqrt{\frac{\sum_{i=1}^{N}\left(X_{i}-\bar{X}\right)^{2}}{N-1}},
$$

Where,

$$
\begin{aligned}
& \mathrm{s}=\text { standard deviation of a sample set } \\
& N=\text { number of specimens in the sample set } \\
& X=\text { a specimen value in the sample set } \\
& \bar{X}=\text { arithmetic mean of the sample set }
\end{aligned}
$$


The standard deviation gives a measure of how the specimen values in the sample set scatter or spread about the arithmetic mean (average). Note that the denominator has the (N-1) expression instead of the more commonly used $(\mathrm{N})$ expression. The standard deviation equation that uses the (N) expression can be converted into the above equation by multiplying the equation or the resulting value by the square root of $\mathrm{N} /(\mathrm{N}-1)$. For example, the standard deviation for a sample set of 5 which uses the $(\mathrm{N})$ expression would be multiplied by the square root of $5 /(5-1)$ to get the same standard deviation value as the equation given above. This new standard deviation is about 12 percent larger than the commonly used standard deviation. For small sample sets (such as the example given), the standard deviation that uses the (N-1) expression gives a better estimate on the dispersion of the data. The use of the above equation does not affect the arithmetic mean of the sample set. For large sample sets (greater than 30 ), there is essentially no difference between the two standard deviation definitions. ${ }^{6}$

Acurex Environmental utilizes a Tinius Olsen Four-Screw Electomatic (120,000 lb. max.) universal testing machine for $\mathrm{c}$-ring testing. Compression testing is performed between the weighing table and the lower crosshead. Tension testing is achieved by movement between the upper crosshead and the lower crosshead. The upper crosshead is stationary, but can be adjusted to certain predetermined locations on the vertical support columns. Lower crosshead displacement is the means to apply load to the specimen. A LVDT was used to measure the displacement of the crosshead movement during testing. The load readings are from a Sensotec load cell (model \#41/571-06). The Sensotec load cell has an accompanying digital meter that is accurate but has no capability for an output signal to a pen recorder. Some load versus displacement data were obtained from the output signal of the LVDT and the Tinius Olsen's analog dial (that reads load).

The crosshead speed for both tension and compression testing was $0.05 \mathrm{in} . / \mathrm{min}$. (1.3 $\mathrm{mm} / \mathrm{min}$.$) .$

The universal test system had to be configured to test the ceramic c-ring specimens of this study. Haynes ${ }^{\circledR}$ Alloy 230 was chosen as the material for the c-ring fixtures. Haynes ${ }^{\circledR}$ Alloy 230 
is a nickel-chromium-tungsten-molybdenum alloy that meets the required properties for $1,000^{\circ} \mathrm{C}$ testing. The design of the c-ring tension/compression fixtures for $3 / 4$ inch max. and 1.25 inch $\max$. c-ring widths are in Appendix B.

The pins (cylindrical rods) needed to assemble different parts of the c-ring fixture to allow articulation, and contact to the c-ring specimens from the inside surface for tension testing must exhibit limited flexure. Pure (99.8\%) $\mathrm{Al}_{2} \mathrm{O}_{3}$ was chosen for this purpose.

To test in the range $650^{\circ} \mathrm{C}$ to $1,000^{\circ} \mathrm{C}$, a single zone vertical clam shell (split tube) furnace (with controller) was used. The ability to open up the furnace and install another specimen after each test was a requirement for expedient testing. A single zone furnace was selected based on the cost. The controller for this furnace allows varying power output that reduces the power output as the set-point temperature is approached. This prevents the overshoot and undershoot cycles characteristic of furnaces that only have on-off capability.

Since the fixtures inside the furnace will reach temperatures of $1,000^{\circ} \mathrm{C}$, the ends of the fixtures that extend from the furnace were water cooled to protect the universal testing machine from damage.

The specimens were sectioned with a diamond blade saw and the slit in the c-ring was also made with the same diamond blade.

Specimens used for testing were obtained from each candle, in sequence, depending upon the amount of material available and the types of testing needed to be done. For example, the following sequencing scheme was adopted if there were enough material to test room temperature tension, high temperature tension, room temperature compression, and high temperature compression from one candle. Each candle was sequentially sectioned and each section labeled from 1 to 20 , from top to bottom. Specimen \#1 would be for room temperature tension, specimen \#2 for room temperature compression, \#3 for high temperature tension, and \#4 for high temperature compression. This sequence would then be repeated starting with specimen \#5 (see Figure 3-10). This sorting scheme resulted in a representative sampling of the strength of each 


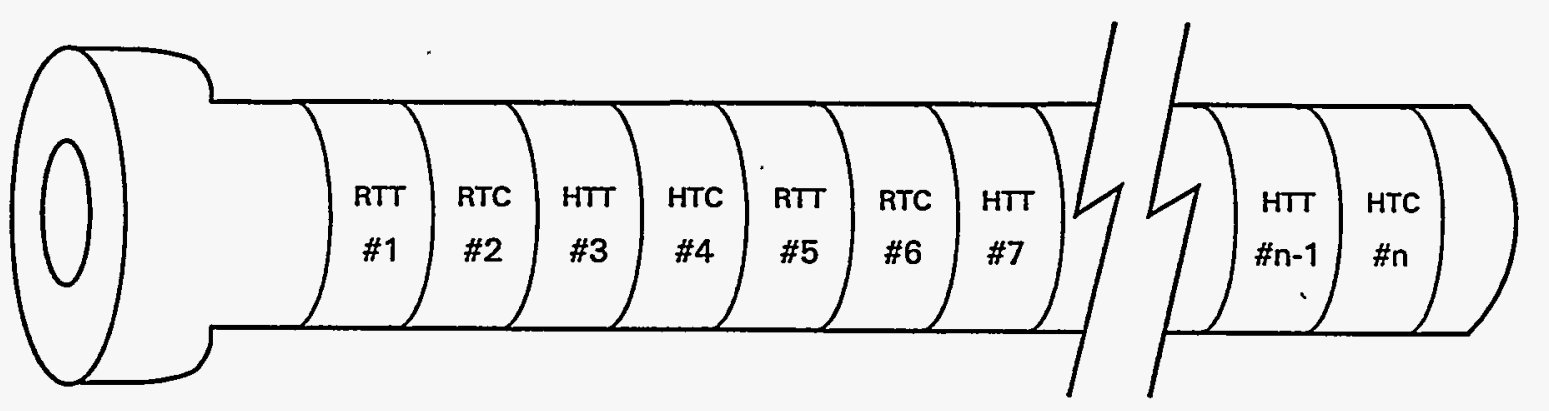

$$
\begin{aligned}
& \text { RTT }=\text { ROOM TEMPERATURE TENSION TESTING } \\
& \text { RTC }=\text { ROOM TEMPERATURE COMPRESSION TESTING } \\
& \text { HTT }=\text { HIGH TEMPERATURE TENSION TESTING } \\
& \text { HTC }=\text { HIGH TEMPERATURE COMPRESSION TESTING }
\end{aligned}
$$

\section{Figure 3-10. C-ring testing sequence from candle filter}

candle (even if there were strength variations along the length of the candle) when tested at the respective conditions.

For high temperature testing, a set of five specimens was put into the furnace, one positioned for testing and the other four preheating inside of the furnace. The thermal expansion of the rams during the heating cycle must be considered, requiring re-positioning of the moving crosshead. After the c-ring specimen is positioned between the tension fixtures, an alumina pin is inserted into the bottom fixture/ram (1) to keep the specimen from rolling off the fixture and (2) to allow the furnace to be closed.

For compression testing, the specimen was ready for testing as soon as the furnace stabilized at the target temperature for about $\mathbf{3 0}$ minutes. For tension testing, the furnace must be reopened to position the specimen and bottom ram (since they are on the moving crosshead) to allow the second alumina pin to be inserted into the top fixture.

Additional information concerning c-ring testing can be found in Appendix C. 


\subsubsection{XRD Analysis}

The interaction between x-rays and the electrons of matter through which it passes will result in the diffraction of the x-rays. A given crystalline substance produces a characteristic diffraction pattern that can be used for identification in a specimen.

For the X-Ray Diffraction (XRD) analyses, a small cross-section of the candle is ground into a fine homogeneous powder. Each particle of the powder is a collection of crystals oriented at random with respect to the incident $\mathrm{x}$-ray. These crystals produce the characteristic diffraction peaks and intensities which can be detected and compared to known standards to identify the crystal phases present. Although amorphous solids by definition have no crystallinity (lack of periodicity), they do have a tendency to "order" in the sense that the atoms are tightly packed together and show a statistical preference for a particular interatomic distance. Hence, the result is an x-ray scattering curve that shows a broad maxima that sometimes look like high background noise. ${ }^{7}$

$\mathrm{XRD}$ provides a macroscopic look at the candle to disclose the chemical combination of elements present, not merely the candle's constituent chemical elements as in other analyses. With sufficient presence of a phase or compound, differences in compounds and phase changes can be detected.

\subsubsection{SEM/EDX Analysis}

The scanning electron microscope (SEM) is used to visually examine surfaces at magnifications higher than that achievable by optical microscopes. In order to get an image, the specimen is scanned by an incident electron beam and the radiation that escapes (such as secondary electrons and characteristic x-rays) is collected and processed. Typically the secondary electron image is used for micrographs because of the considerable depth of focus that gives a "threedimensional" appearance to rough specimens.

An energy dispersive $x$-ray (EDX) detector is used in conjunction with a SEM to provide quantitative analysis of specific areas being viewed by the SEM. This technique allows determination of the surface elemental composition. The EDX detector used will not determine 
elements of atomic weights less than 23 (sodium). Elements such as carbon, oxygen, and nitrogen were therefore not determined.

Visual SEM examination of the candle surface morphology provides insight into the binder and grain interaction that produces the filtration properties, as well as the physical changes due to operational conditions. EDX analysis can indicate the presence of elements that may have detrimental effects on the operational properties of the ceramic candles. Therefore, the SEM/EDX analyses performed in this project provided microscopic examination and documentation for visual, as well as elemental comparisons of used and unused candles.

\subsubsection{Thermal Ratcheting}

Currently, all ceramic candle filter systems use pulse cleaning as the filter-cleaning mechanism. Filters are usually pulse cleaned in either of two ways: pressure-triggered or timetriggered cleaning pulses. In either case, however, typical cleaning intervals (time between pulses) can range from 3 minutes to as long as 1 to 2 hours, depending on dust load and dust characteristics. The thermal ratcheting tests is to determine the extent to which pulse cleaning degrades the candle filter material.

Accelerated pulse cleaning (thermal ratcheting) and filter efficiency testing were performed on a bench-scale filter evaluation apparatus operating at $870^{\circ} \mathrm{C}$ and atmospheric pressure. Figure 3-11 is a schematic of the bench-scale filter test facility. Each of the specimens were exposed to a total of 5,000 pulses with a 30-second time interval between each pulse cleaning. Therefore the total time to complete each accelerated pulse cleaning test was about 42 hours. The pulse gas was at room temperature in the reservoir tank. The pulse gas reservoir was set at $80 \mathrm{psig}$ and was released into the candle specimens (each specimen was 1-foot long) through a time-triggered solenoid valve. The materials exposed to the accelerated pulse cleaning conditions are the Schumacher Diaschumalith F40, IFP LayCer, Didier SiC20, and the IFP Fibrosics candles. 


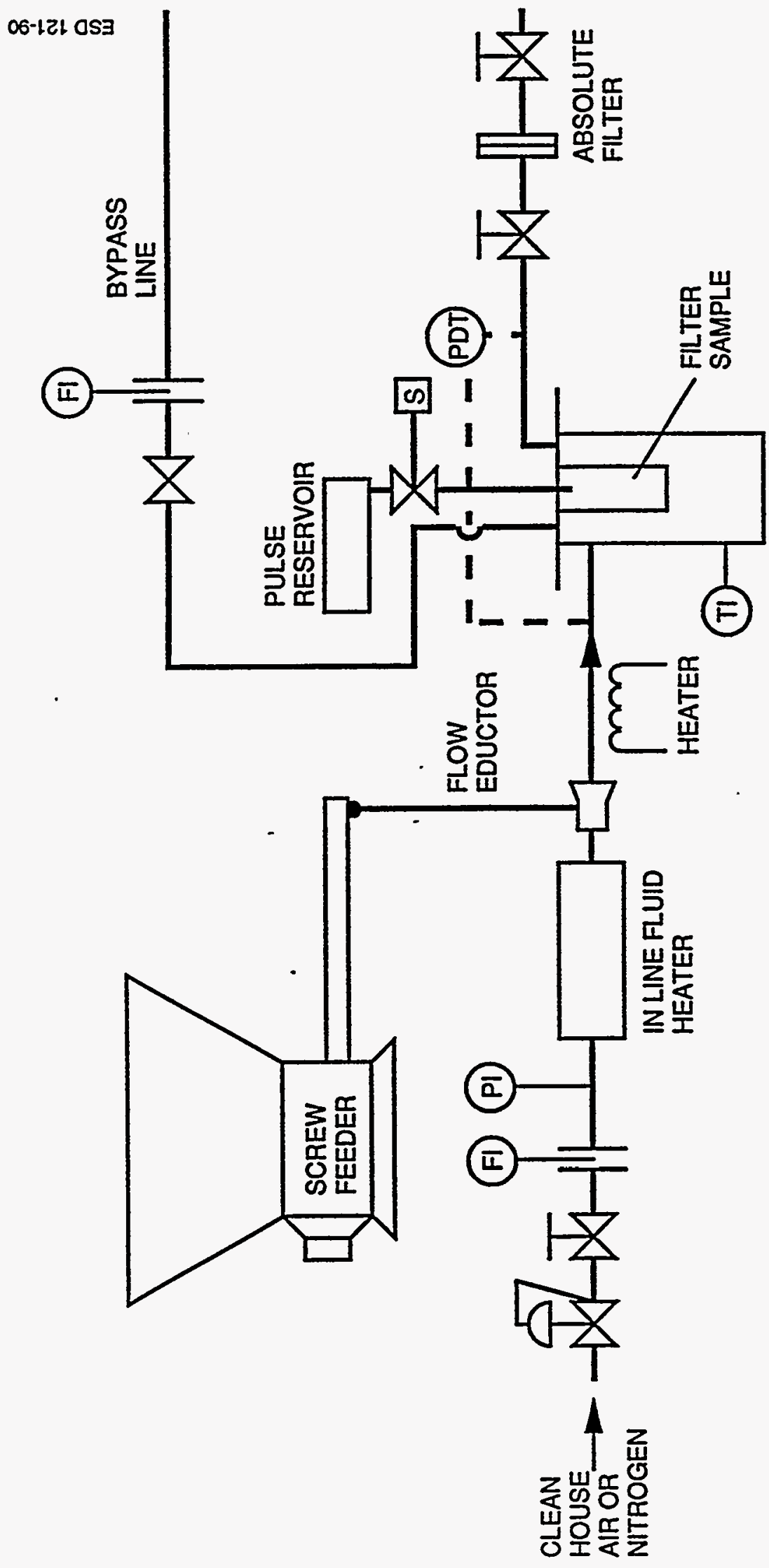

导 


\subsubsection{Fibrosics Testing}

\subsubsection{Fibrosic Candle}

The IFP Fibrosics candle is a new type of candle for which there is little public information available. The bench-scale filter facility was used to perform collection efficiency and permeability testing. The collection efficiency tests were performed at $870^{\circ} \mathrm{C}$ with a dust loading of $4,000 \mathrm{ppm}_{\mathrm{w}}$. The dust used is Curtis Wright PFBC flyash $\left(D_{50}=4.7 \mu \mathrm{m}\right)$.

Since the IFP Fibrosic candle is relatively "soft" compared to the rigid candles, c-ring testing could not be performed to measure the strength of the candles. The strength measurements would be at the lower limits of the c-ring testing system. Hence, burst testing would be used to ascertain the strength of the candles. In burst testing, a rubber bladder is inserted into the bore of the candle. The candle and bladder (pre-filled with water) is then fitted into the burst tester before a hydraulic pump is activated to pressurize the bladder/candle assembly. The burst pressure of the candle is the specified pressure at which the candle fails.

\subsubsection{Fibrosic Tubesheet}

IFP had also developed a fibrous ceramic tubesheet and candle hold-down system. This approach has appeal by reducing the amount of metal subjected to high temperature gas. The tubesheet/hold-down assembly had not been subjected to sufficient testing. There was no long term testing data of the structural integrity of the Fibrosic tubesheet at high temperature. This structural loading test entailed the use of a section of the Fibrosic tubesheet to simulate (when possible) the "worst" case structural conditions that the tubesheet can encounter.

Figure 3-12 shows the Fibrosic tubesheet design that this experiment is based upon. The high density of candle filter holes would represent the least amount of supporting tubesheet material surrounding each candle filter. The two parallel alumina/mullite support design was chosen instead of the four parallel support design because the two support design maximizes the distance between the supports which would allow the tubesheet between the supports to experience the worst case scenario. Only a section of the tubesheet was tested. With the two support design, the tubesheet 


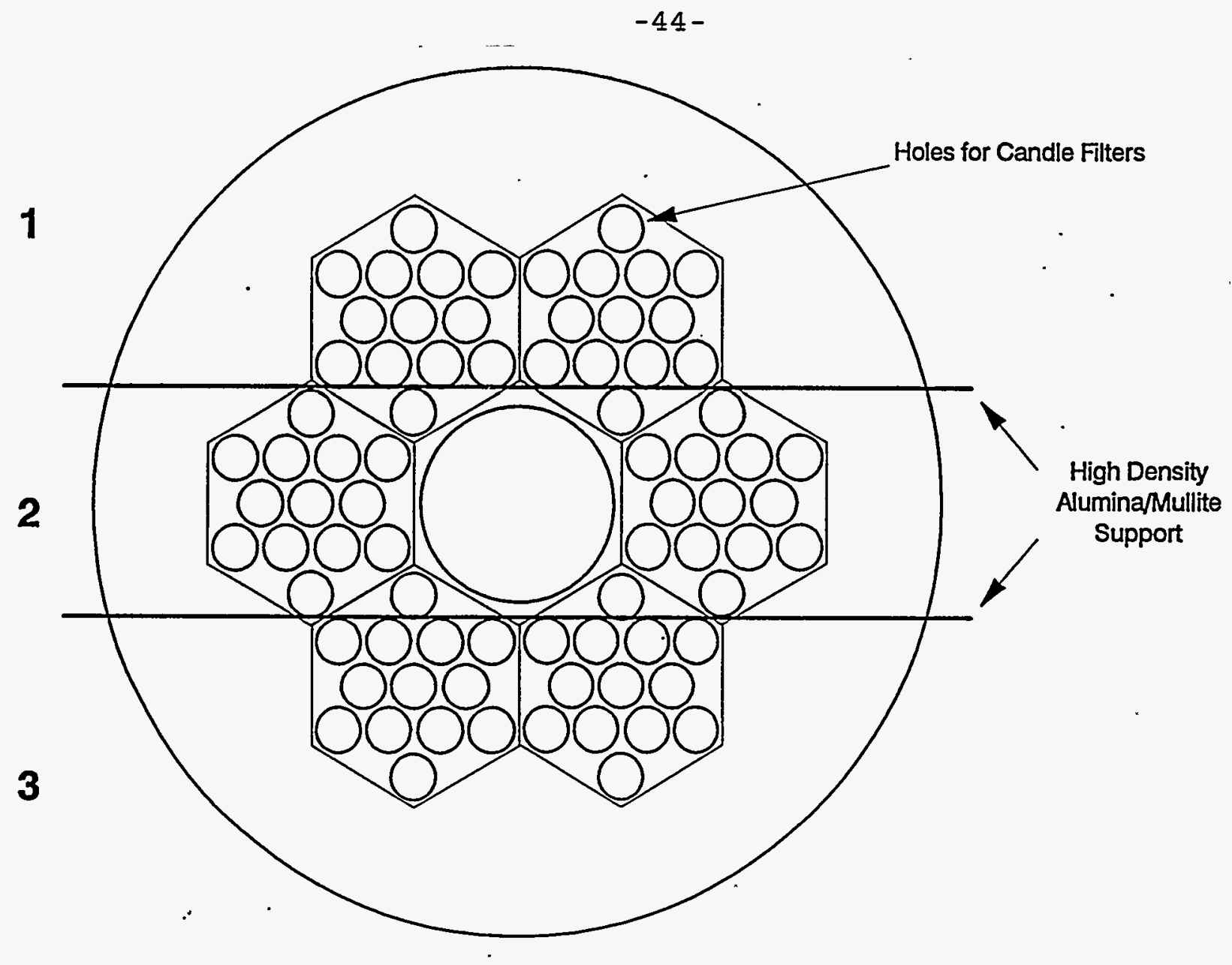

Figure 3-12. Fibrosic tubesheet

is divided into three sections denoted on to Figure 3-12. The middle section (labeled as number "2" in Figure 3-12) was selected because the center section has the most holes lying around the center line parallel to the supports. Having a high density of holes around the center line of the tubesheet would have the most effect on weakening the strength of the tubesheet.

Testing of the complete middle section of the tube sheet (see Figure 3-13) is not necessary because bending is expected about the lines in the axial direction parallel to the two supports. Bending of the supports is not expected due to the strength of the high density alumina/mullite. Therefore the only bending will be inwards and downwards between the two supports. Since the big hole in the center of the middle section essentially separates the section into two parts and there is symmetry between the two halves, then only half of the middle section is required to test the integrity of the tubesheet at high temperature. Figure 3-14 shows the tubesheet section procured 


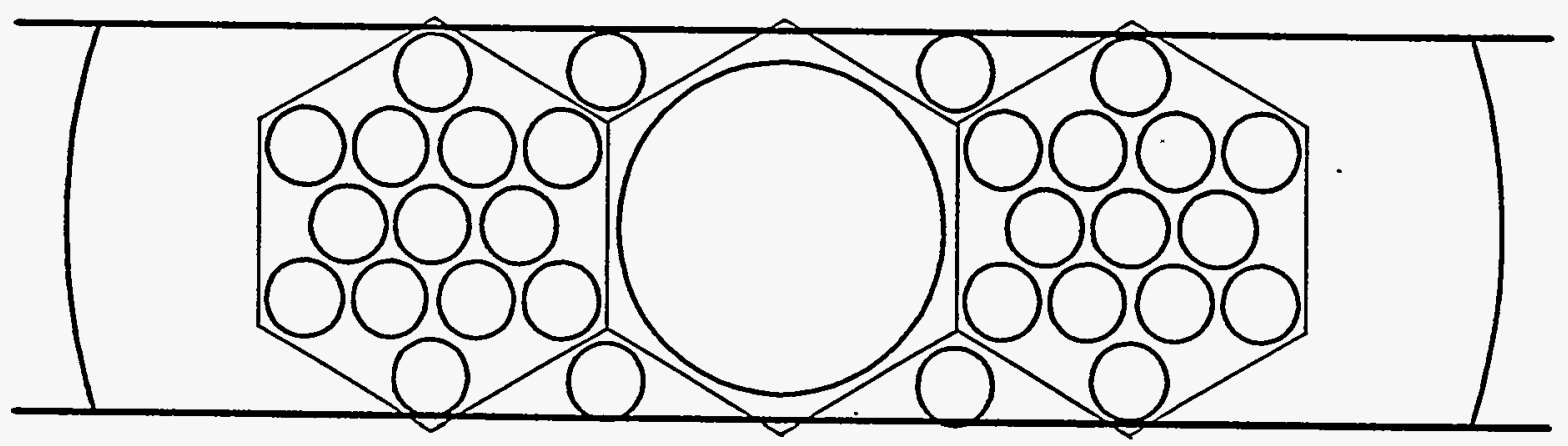

Figure 3-13. Middle section of Fibrosic tubesheet

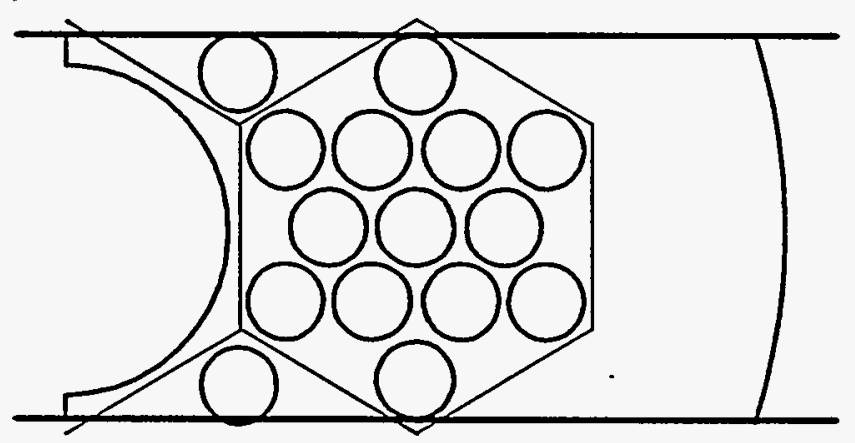

Figure 3-14. Section of Fibrosic tubesheet tested

from IFP. In the oven, the tubesheet (supported by the two 1.5-inch wide alumina/mullite supports) was placed on four refractory bricks to elevate the tubesheet above the heaters. Each of the four bricks was placed under the one of the four ends of the two supporting members. Since the members were not fixed, the supports were allowed to rotate inwards and downwards between the supports (see Figure 3-15). This is a worst case situation because in reality, the tubesheet on the outside of the supports (sections "1" and " 3 " which are non existent in this test) would produce an outward and upward force on the middle section of the tubesheet that would reduce the inward and downward forces caused by the weight in the middle section of the tubesheet.

Figure 3-16 is a cross-sectional view of a candle filter hole in the Fibrosic tubesheet. To simulate the loading of the tubesheet encountered during operation, a ceramic disc with the same 


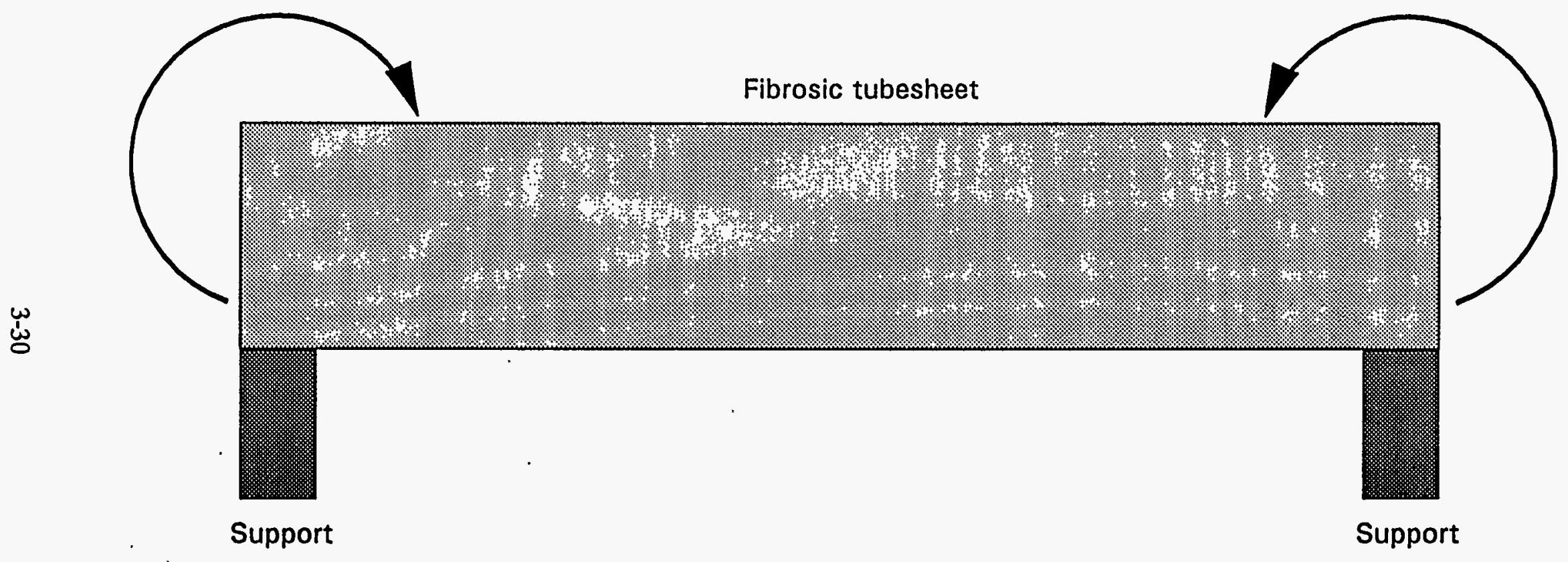

15

Figure 3-15. End-view of Fibrosic tubesheet tested 


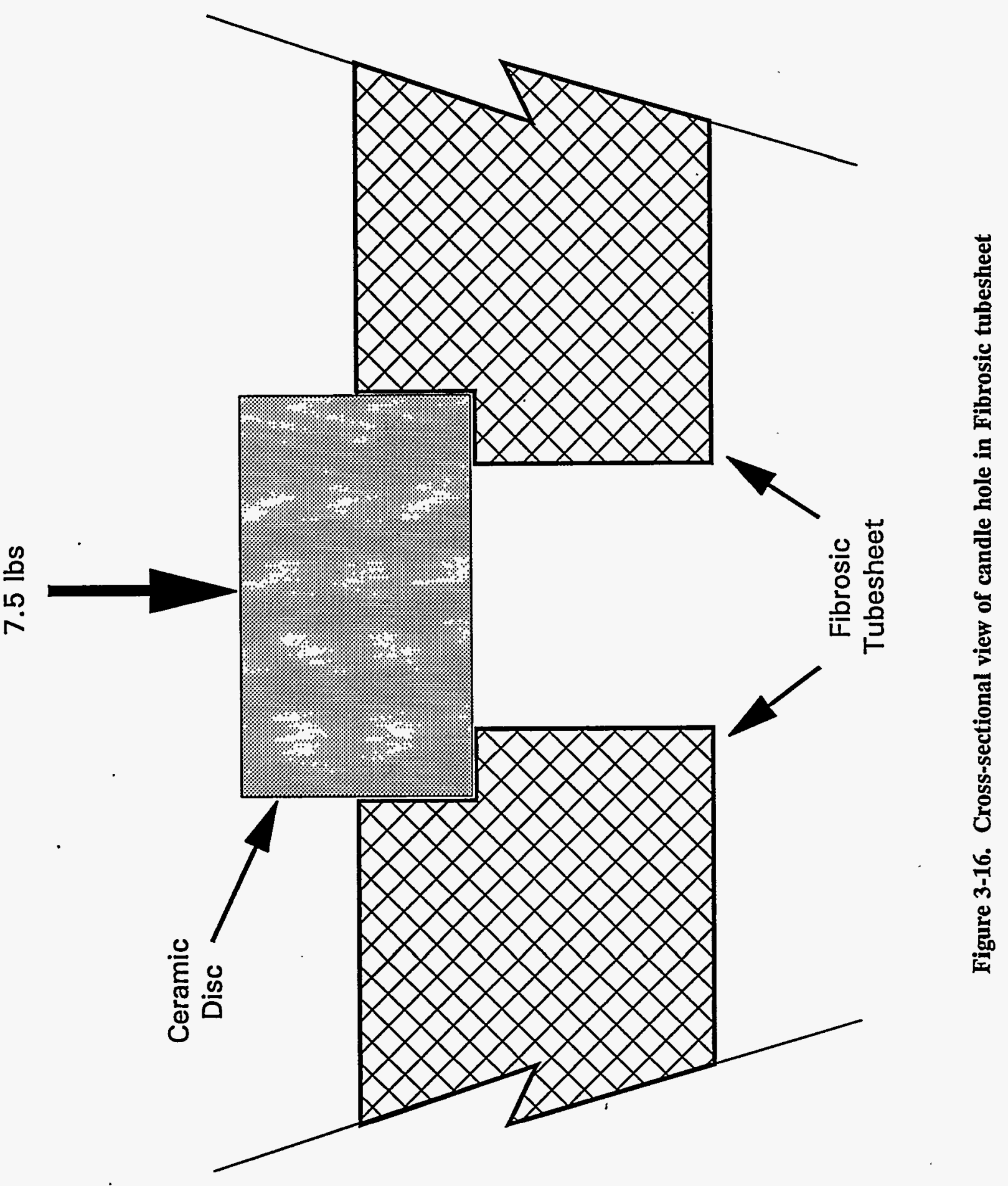


diameter as the outside diameter of a candle filter flange was inserted into the candle hole of the tubesheet (refer to Figure 3-16). The bottom of the disc was in contact with the same surfaces that the candle filter flange would be in contact with. The thickness of the disc is about double the thickness of the candle flange because the weights to be placed on the disc must not be in contact with the top of the tubesheet. In operation, the weight of the candle and any ash which is deposited on the candle is transmitted to the tubesheet primarily via the bottom surface of the candle flange. The weight of a 1.5 meter long candle filter is about 2.5 pounds. The weight of 7.5 pounds per candle hole is derived from an assumption of a dust dry bulk density of $15 \mathrm{lb} / \mathrm{ft}^{3}$ which is in a "bridged" (worst case) condition between the candles (as well as having significant ash penetration into the candle body). The total weight $113 \mathrm{lbs}$ was used to load the tubesheet. ${ }^{8}$

In operation, the filter tubesheet is also supported in addition to the ceramic support beams by a peripheral "ledge" that extends several inches under the circumference of the tubesheet. To simulate the worst case scenario, no supporting "ledge" was used in the load test.

To measure deflection of the tubesheet at $870^{\circ} \mathrm{C}$ during the 500 hour test, thin alumina rods resting on the surface of the tubesheet were extended vertically through the top of the oven to allow for measurements of the vertical displacement of the alumina rods above the oven as a function of time. 


\section{SECTION 4}

\section{THERMAL/MECHANICAL TEST RESULTS AND ANALYSIS}

\subsection{C-RING TESTING}

The c-ring tension test results are presented in Tables 4-1, 4-2, and 4-3. The c-ring compression test results are presented in Tables 4-4, 4-5, and 4-6. Tables 4-1 and 4-4 are for the Schumacher Diaschumalith candles, Tables 4-2 and 4-5 show the Refractron candle results, and Tables 4-3 and 4-6 show the c-ring test results of the IFP LayCer and the Didier SiC20 candles. The row headings in the c-ring compression tables (Tables 4-4, 4-5, and 4-6) correspond to the same sequence of row headings in the c-ring tension tables. Hence, there are some rows in the compression tables that may not have any data because'only c-ring tension tests were performed. These tables show the average maximum stress values for each individual candle tested (with its corresponding standard deviation). The raw data used for these results are detailed in Appendix D.

\subsubsection{C-Ring Testing: Preliminary Investigations}

The typical c-ring specimen width is 0.75 inches. Due to the design and size limitations of the thermal exposure test facility, c-ring widths of 0.50 inches were used. To investigate the possibility of specimen size influencing the strength measurements, Acurex Environmental performed c-ring tension and compression tests on $0.50-, 0.75-, 1.00-$, and 1.25-in. specimens on Schumacher and Refractron candles. The data obtained from these tests are summarized in Table 4-7. Figures 4-1, 4-2, 4-3, and 4-4 graphically displays the data presented in Table 4-7. The raw data can be found in Appendix D.

The above graphs demonstrate that the maximum stress values derived from 0.5 -in c-ring specimens are representative of the strength of the candle. Although the average maximum stress 
Table 4-1. C-ring tension testing: Schumacher Diaschumalith

\begin{tabular}{|c|c|c|c|c|c|c|c|c|c|}
\hline \multirow{4}{*}{ CANDLE DESCRIPTION } & \multirow{4}{*}{$\begin{array}{c}\text { C-ring } \\
\text { Width } \\
\text { (inches) }\end{array}$} & \multicolumn{8}{|c|}{ C-RING TENSION TESTING } \\
\hline & & \multicolumn{2}{|c|}{ Room Temp } & \multicolumn{2}{|c|}{$650^{\circ} \mathrm{C}$} & \multicolumn{2}{|c|}{$870^{\circ} \mathrm{C}$} & \multicolumn{2}{|c|}{$980^{\circ} \mathrm{C}$} \\
\hline & & Stress & \pm Std & Stress & \pm Std & Stress & \pm Std & Stress & \pm Std \\
\hline & & (MPa) & Dev & $(\mathrm{MPa})$ & Dev & $(\mathrm{MPa})$ & Devl & (MPa) & Dev \\
\hline \multirow{3}{*}{ SCHUMACHER DIASCHUMALITH } & & & & & & & 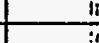 & 13 & \\
\hline & & & & & & & $i$ & & \\
\hline \multirow{2}{*}{\multicolumn{10}{|c|}{ F30 CANDLE }} \\
\hline & & & & & & & & & \\
\hline & & & & & & & & & \\
\hline \multicolumn{10}{|l|}{ UNUSED } \\
\hline \multirow[t]{2}{*}{ For KRW test (7068) } & $3 / 4^{\prime \prime}$ & 24.29 & 1.00 & 25.02 & 1.29 & & & & \\
\hline & & & & & & & & & \\
\hline \multicolumn{10}{|l|}{ USED/EXPOSED } \\
\hline KRW (7052) & $3 / 4^{\prime \prime}$ & 18.21 & 1.38 & 19.60 & 0.99 & & & & \\
\hline \multirow{5}{*}{ KRW (7067) } & $3 / 4^{\prime \prime}$ & 18.10 & 0.83 & 21.27 & 0.49 & & & & \\
\hline & & & & & & & & & \\
\hline & & & & & & & & & \\
\hline & & & & & & & & & \\
\hline & & & & & & & & & \\
\hline \multicolumn{10}{|l|}{ F40 CANDLE } \\
\hline & & & & & & & & & \\
\hline \multicolumn{10}{|l|}{ UNUSED } \\
\hline SOLAR & $3 / 4^{\prime \prime}$ & 5.17 & 0.55 & & & & & 4.43 & 0.24 \\
\hline SOLAR & $3 / 4^{\prime \prime}$ & & & & & 6.74 & 0.69 & 4.60 & 1.75 \\
\hline SOLAR & $1 / 2^{\prime \prime}$ & & & & & $6: 11$ & 0.36 & 4.32 & 0.46 \\
\hline \multirow[t]{2}{*}{ For 5000 pulse test } & $3 / 4^{\prime \prime}$ & 8.23 & 0.59 & & & 8.60 & 0.62 & & \\
\hline & & & & & & & & & \\
\hline \multicolumn{10}{|l|}{ EXPOSURE TESTING } \\
\hline \multirow{3}{*}{ Control: 500 hrs at $870^{\circ} \mathrm{C}$ only } & & & & & & & & & \\
\hline & $1 / 2^{11}$ & & & & & 7.92 & $1.01:$ & & \\
\hline \multirow{2}{*}{\multicolumn{10}{|c|}{ 95ppm NaCl/20\%H2O/870 $\mathrm{C}$}} \\
\hline & & & & & & & & & \\
\hline 100hr/No Pulse (A) & $1 / 2^{11}$ & & & & & 4.85 & 0.33 & & \\
\hline & & & & & & & & & \\
\hline $65 \mathrm{ppm} \mathrm{NaCl} / 20 \% \mathrm{H} 2 \mathrm{O} / 980^{\circ} \mathrm{C}$ & & & & & & & & & \\
\hline 100hr/Pulse (B) & $1 / 2^{\prime \prime}$ & & & & & & & 1.79 & 0.73 \\
\hline 475hr/Pulse (C) & $1 / 2^{\prime \prime}$ & & & & & & & 2.69 & 0.45 \\
\hline 575hr/Pulse (D) & $1 / 2^{11}$ & & & & & & & 2.51 & 0.25 \\
\hline & & & & & & & & & \\
\hline $20 \mathrm{ppm} \mathrm{NaCl} / 15 \% \mathrm{H} 2 \mathrm{O} / 870^{\circ} \mathrm{C}$ & & & & & & & & & \\
\hline 100hr/Pulse (E) & $.1 / 2^{11}$ & & & & & 5.72 & 0.39 & & \\
\hline 400hr/Pulse (F) & $1 / 2^{11}$ & & & & & 4.76 & 2.14 & & \\
\hline 500hr/Pulse (G) & $1 / 2^{11}$ & & & & & 8.43 & 0.54 & & \\
\hline 1000hr/Pulse (H) & $1 / 2^{\prime \prime}$ & & & & & 4.64 & 0.01 & & \\
\hline & & & & & & & & & \\
\hline & & & & & & & & & \\
\hline & & & & & & & & & \\
\hline & & & & & & & & & \\
\hline & & & & & & & $i$ & 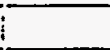 & \\
\hline $1 / 3$ & & & & & & & $i$ & 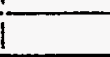 & \\
\hline
\end{tabular}


Table 4-2. C-ring tension testing: Refractron Lessthan 5 specimens avallable for testing

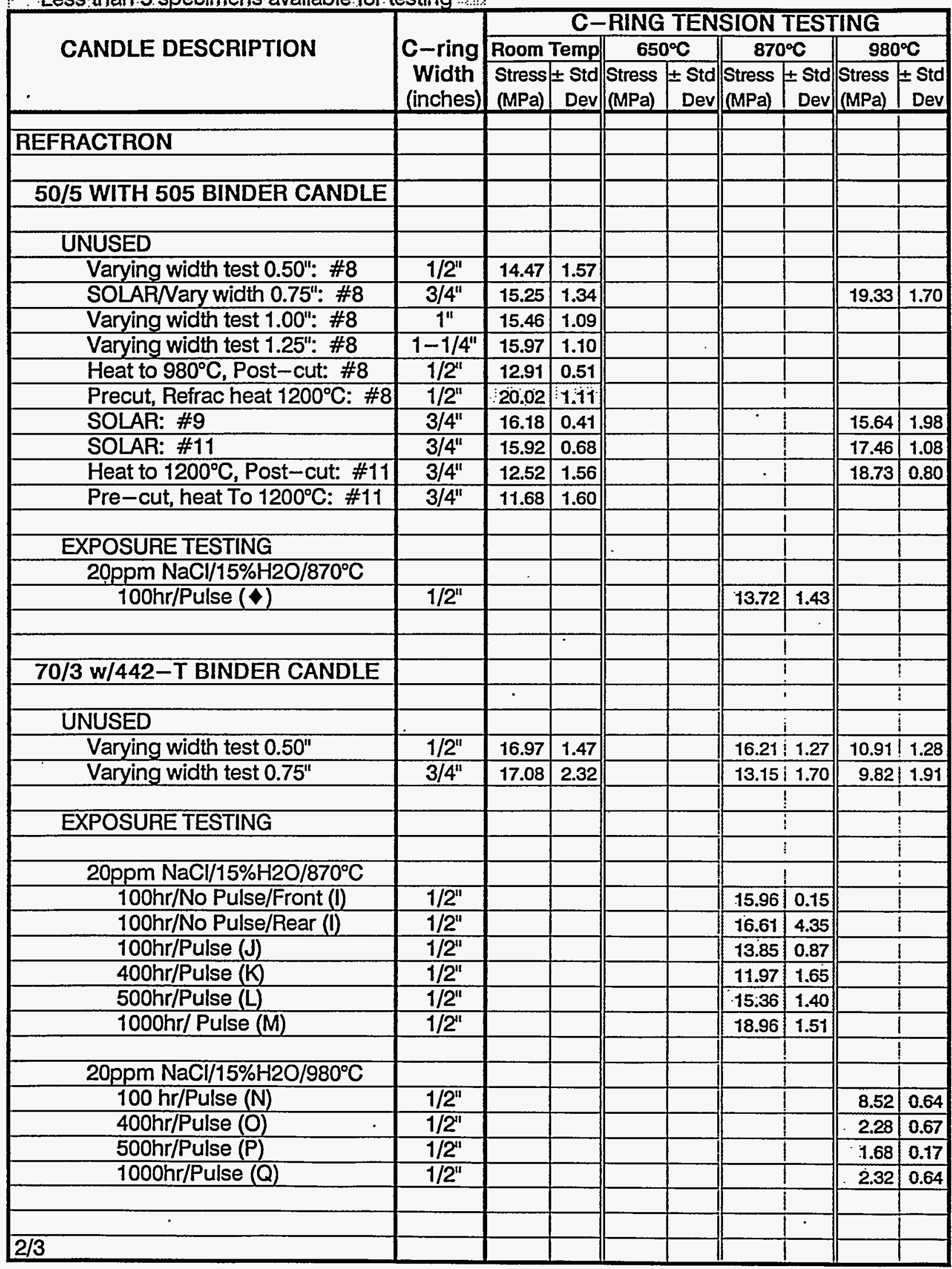


Table 4-3. C-ring tension testing:

IFP LayCer and Didier SiC20

\begin{tabular}{|c|c|c|c|c|c|c|c|c|c|}
\hline \multirow{3}{*}{ CANDLE DESCAIPTION } & \multirow{3}{*}{$\begin{array}{l}\text { C-ring } \\
\text { Width } \\
\text { (inches) }\end{array}$} & \multicolumn{8}{|c|}{ C-RING TENSION TESTING } \\
\hline & & \multicolumn{2}{|c|}{ Room Temp } & \multicolumn{2}{|c|}{$650^{\circ} \mathrm{C}$} & \multicolumn{2}{|c|}{$870^{\circ} \mathrm{C}$} & \multicolumn{2}{|c|}{$980^{\circ} \mathrm{C}$} \\
\hline & & $\begin{array}{l}\text { Stress } \\
(\mathrm{MPa})\end{array}$ & $\begin{array}{r} \pm S t d \\
\text { Dev }\end{array}$ & $\begin{array}{l}\text { Stress } \\
(\mathrm{MPa})\end{array}$ & \begin{tabular}{|r|} 
Std \\
Dev
\end{tabular} & $\begin{array}{l}\text { Stress } \\
(\mathrm{MPa})\end{array}$ & $\begin{array}{r} \pm \text { Std } \\
\text { Dev }\end{array}$ & $\begin{array}{l}\text { Stress } \\
(\mathrm{MPa})\end{array}$ & $\begin{array}{r}+ \text { Std } \\
\text { Dev }\end{array}$ \\
\hline \multicolumn{10}{|l|}{ IFP LAYCER CANDLE } \\
\hline & & & & & & & . & & \\
\hline \multicolumn{10}{|l|}{ UNUSED } \\
\hline \multirow[t]{2}{*}{ For $1000 / 5000$ pulse tests } & $3 / 4^{\prime \prime}$ & 18.18 & 1.17 & & & 15.98 & 2.26 & & \\
\hline & & & & & & & & & \\
\hline \multicolumn{10}{|l|}{ USED/EXPOSED } \\
\hline 1000 pulses @0.05 sec. & $3 / 4^{\prime \prime}$ & 18.66 & 1.33 & & & & & & \\
\hline 5000 pulses@0.05 sec. & $3 / 4^{\prime \prime}$ & 20.56 & 1.97 & & & & & & \\
\hline 5000 pulses @0.5 sec. & $3 / 4^{\prime \prime}$ & 13.22 & 0.38 & & & 17.96 & 1.59 & & \\
\hline \multirow[t]{2}{*}{ DOE } & $3 / 4^{\prime \prime}$ & 11.90 & 3.29 & & & 11.43 & 2.68 & & \\
\hline & & & & & & & & & \\
\hline \multicolumn{2}{|c|}{2} & & & & & & & & \\
\hline 20 & & & & & & & & & \\
\hline \multicolumn{2}{|c|}{ 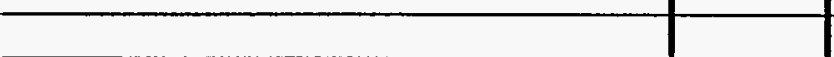 } & & & & & & & & \\
\hline \multicolumn{2}{|c|}{ 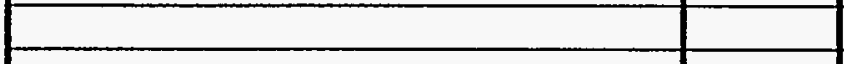 } & & & & & & & & \\
\hline & & & & & & & & & \\
\hline \multicolumn{10}{|l|}{ DIDIER SiC20 } \\
\hline & & & & & & & & & \\
\hline \multicolumn{10}{|l|}{ UNUSED } \\
\hline For 0.05 sec. pulse test & $3 / 4^{\prime \prime}$ & 32.54 & 4.96 & & & & & & \\
\hline \multirow[t]{2}{*}{ Comparing outer vs inner } & $3 / 4^{\prime \prime}$ & 27.13 & 2.41 & & & & & & \\
\hline & & & & & & & & & \\
\hline \multicolumn{10}{|l|}{ USED/EXPOSED } \\
\hline \multirow[t]{5}{*}{0.05 sec. pulses } & $3 / 4^{\prime \prime}$ & 28.94 & 4.49 & & & & & & \\
\hline & & & & & & & & & \\
\hline & & & & & & & & & \\
\hline & & & & & & & & & \\
\hline & & & & & & & & & \\
\hline & & & & & & & & & \\
\hline & & & & & & & & & \\
\hline & & & & & & & & & \\
\hline & & & & & & & & & \\
\hline & & & & & & & & & \\
\hline & & & & & & & & & \\
\hline & & & & & & & & & \\
\hline & & & & & & & & & \\
\hline & & & & & & & & & \\
\hline & & & & & & & & & \\
\hline & & & & & & & & & \\
\hline & & & & & & & & & \\
\hline & & & & & & & & & \\
\hline $3 / 3$ & & & & & & & & & \\
\hline
\end{tabular}


Table 4-4. C-ring compression testing: Schumacher Diaschumalith

Less than 5 specimens avallable for festing ?

CANDLE DESCRIPTION

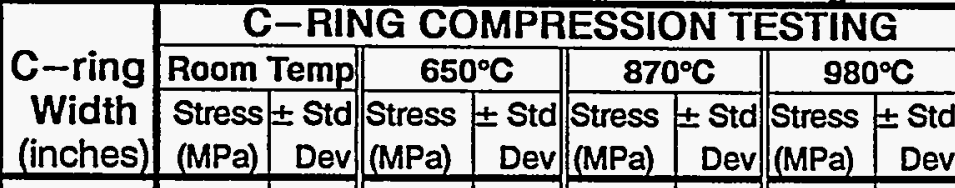

\section{SCHUMACHER DIASCHUMALITH}

F30 CANDLE

UNUSED

For KRW test (7068)

USED/EXPOSED

KRW (7052)

KRW (7067)

(inches) (MPa) Dev (MPa) Dev (MPa) Dev (MPa) Dev

\section{F40 CANDLE}

UNUSED

SOLAR

SOLAR

SOLAR

For 5000 pulse test

EXPOSURE TESTING

Control: $500 \mathrm{hrs}$ at $870^{\circ} \mathrm{C}$ only

$95 \mathrm{ppm} \mathrm{NaCl} / 20 \% \mathrm{H} 2 \mathrm{O} / 870^{\circ} \mathrm{C}$ $100 \mathrm{hr} /$ No Pulse (A)

$65 p p m ~ N a C l / 20 \% \mathrm{H} 2 \mathrm{O} / 980^{\circ} \mathrm{C}$

$100 \mathrm{hr} /$ Pulse (B)

475hr/Pulse (C)

575hr/Pulse (D)

20ppm NaCl/15\%H2O/870 ${ }^{\circ} \mathrm{C}$

100hr/Pulse (E)

400hr/Pulse (F)

500hr/Pulse (G)

$1000 \mathrm{hr} /$ Pulse (H)

\section{$3 / 4^{\prime \prime}$

$3 / 4^{\prime \prime}$

$1 / 2^{\prime \prime}$

$3 / 4^{\prime \prime}$

$\begin{array}{llllll}17.58 & 2.18 & 18: 89 & 1.48\end{array}$

$3 / 4^{\prime \prime}$

\begin{tabular}{|l|l|l|l|}
\hline 20.81 & 1.08 & 21,36 & 0.79 \\
\hline
\end{tabular}

$(-2$

$1 / 2^{11}$

21.160 .96

$25.38,1.84$

0.43 
Table 4-5. C-ring compression testing: Refractron

Less than 5 specimens available for testing

CANDLE DESCRIPTION

\begin{tabular}{|c|c|c|c|c|}
\hline & C-RII & COM & SSION & IING \\
\hline -ring & Room Temp & $650^{\circ} \mathrm{C}$ & $870^{\circ} \mathrm{C}$ & \\
\hline
\end{tabular}

Width Stress \pm Std Stress \pm Std Stress \pm Std Stress \pm Std

(inches) (MPa) Dev (MPa) Dev (MPa) Dev (MPa) Dev

\section{REFRACTRON}

50/5 WITH 505 BINDER CANDLE

UNUSED

Varying width test 0.50 ": \#8

SOLARNary width $0.75^{\prime \prime}:$ \#8

Varying width test 1.00": \#8

Varying width test 1.25": \#8.

Heat to $980^{\circ} \mathrm{C}$, Post-cut: \#8

Precut, Refrac heat $1200^{\circ} \mathrm{C}: \# 8$

SOLAR: \#9

SOLAR: \#11

Heat to $1200^{\circ} \mathrm{C}$, Post-cut: \#11

Pre-cut, heat To $1200^{\circ} \mathrm{C}: \# 11$

EXPOSURE TESTING

$20 \mathrm{ppm} \mathrm{NaCl} / 15 \% \mathrm{H} 2 \mathrm{O} / 870^{\circ} \mathrm{C}$ $100 \mathrm{hr} / \mathrm{Pulse}(\downarrow)$

\section{0/3 w/442-T BINDER CANDLE}

UNUSED

Varying width test $0.50^{\prime \prime}$

Varying width test $0.75^{\prime \prime}$

EXPOSURE TESTING

$20 \mathrm{ppm} \mathrm{NaCl} / 15 \% \mathrm{H} 2 \mathrm{O} / 870^{\circ} \mathrm{C}$ $100 \mathrm{hr} /$ No Pulse/Front (I) 100hr/No Pulse/Rear (1)

100hr/Pulse (J)

400hr/Pulse (K)

$500 \mathrm{hr} /$ Pulse (L)

$1000 \mathrm{hr} /$ Pulse (M)

$20 p p m ~ N a C l / 15 \% H 2 O / 980^{\circ} \mathrm{C}$ $100 \mathrm{hr} /$ Pulse (N)

400hr/Pulse (O)

$500 \mathrm{hr} /$ Pulse (P)

1000hr/Pulse (Q)

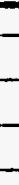

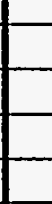


Table 4-6. C-ring compression testing: IFP LayCer/Didier SiC20

\begin{tabular}{|c|c|c|c|c|c|c|c|c|c|}
\hline \multirow{3}{*}{ CANDLE DESCRIPTION } & \multirow{3}{*}{$\begin{array}{l}\text { C-ring } \\
\text { Width } \\
\text { (inches) }\end{array}$} & \multicolumn{8}{|c|}{ C-RING COMPRESSION TESTING } \\
\hline & & \multicolumn{2}{|c|}{ Room Temp } & \multicolumn{2}{|c|}{$650^{\circ} \mathrm{C}$} & \multicolumn{2}{|c|}{$870^{\circ} \mathrm{C}$} & \multicolumn{2}{|c|}{$980^{\circ} \mathrm{C}$} \\
\hline & & $\begin{array}{l}\text { Stress } \\
\text { (MPa) }\end{array}$ & $\begin{array}{r} \pm \text { Std } \\
\text { Dev }\end{array}$ & $\begin{array}{l}\text { Stress } \\
(\mathrm{MPa})\end{array}$ & $\begin{array}{r} \pm S t c \\
\text { Dev }\end{array}$ & $\begin{array}{l}\text { Stress } \\
(\mathrm{MPa})\end{array}$ & $\begin{array}{r} \pm \text { Std } \\
\text { Dev }\end{array}$ & $\begin{array}{l}\text { Stress } \\
\text { (MPa) }\end{array}$ & $\begin{array}{r}\text { Std } \\
\text { Dev }\end{array}$ \\
\hline \multirow{2}{*}{\multicolumn{10}{|c|}{ IFP LAYCER CANDLE }} \\
\hline & & & & & & & & & \\
\hline \multirow{2}{*}{\multicolumn{10}{|c|}{ UNUSED }} \\
\hline & & & & & & & & & \\
\hline \multirow{2}{*}{ For $1000 / 5000$ pulse tests } & $3 / 4^{11}$ & & & & & & & & \\
\hline \multirow{2}{*}{\multicolumn{10}{|c|}{ USED/EXPOSED }} \\
\hline & & & & & & & & & \\
\hline 1000 pulses @0.05 sec. & $3 / 4^{\prime \prime}$ & & & & & & & & \\
\hline 5000 pulses @0.05 sec. & $3 / 4^{\prime \prime}$ & & & & & & & & \\
\hline 5000 pulses @0.5 sec. & $3 / 4^{\prime \prime}$ & & & & & & & & \\
\hline \multirow{2}{*}{ DOE } & $3 / 4^{\prime \prime}$ & 21.49 & 1.64 & & & 17.85 & 1.87 & & \\
\hline & & & & $\cdot$ & & & & & \\
\hline & & & & & & & & & \\
\hline & & & & & & & & & \\
\hline & & & & & & & & & \\
\hline & & & & & & & & & \\
\hline & & & & & & & & & \\
\hline \multicolumn{10}{|l|}{ DIDIER SiC20 } \\
\hline & & & & & & & & & \\
\hline \multicolumn{10}{|l|}{ UNUSED } \\
\hline For 0.05 sec. pulse test & $3 / 4^{11}$ & & & & & & & & \\
\hline \multirow[t]{2}{*}{ Comparing outer vs inner } & $3 / 4^{11}$ & 28.22 & 2.35 & & & & & & \\
\hline \multirow{2}{*}{\multicolumn{10}{|c|}{ USED/EXPOSED }} \\
\hline & & & & & & & & & \\
\hline \multirow[t]{2}{*}{$0.05 \mathrm{sec}$. pulses } & $3 / 4^{\prime \prime}$ & & & & & & & & \\
\hline & & & & & & & & & \\
\hline & & & & & & & & & \\
\hline & & & & & & & & & \\
\hline & & & & & & & & & \\
\hline & & & & & & & & & \\
\hline & & & & & & & & & \\
\hline & & & & & & & & & \\
\hline - & & & & & & & & & \\
\hline & & & & & & & & & \\
\hline & & & & & & & & & \\
\hline & & & & & & & & & \\
\hline & & & & & & & & & \\
\hline & & & & & & & & & \\
\hline & & & & & & & & & \\
\hline & & & & & & & & & \\
\hline & & & & & & & & & \\
\hline & & & & & & & & & \\
\hline $3 / 3$ & & & & & & & & & \\
\hline
\end{tabular}


Table 4-7. Summary of c-ring tension/compression tests investigating the effect of sample width on c-ring strength measurement

\begin{tabular}{|l|c|c|c|c|c|c|}
\hline & \multirow{2}{*}{$\begin{array}{l}\text { C-Ring } \\
\text { Width } \\
\text { (inch) }\end{array}$} & \multirow{2}{*}{$\begin{array}{c}\text { Temperature } \\
\left({ }^{\circ} \text { C) }\right.\end{array}$} & \multicolumn{2}{|c|}{ Tension } & \multicolumn{2}{c|}{ Compression } \\
\cline { 4 - 7 } & & $\begin{array}{c}\text { Stress } \\
(\text { Mpa })\end{array}$ & $\begin{array}{c} \pm \text { Std } \\
\text { Dev }\end{array}$ & $\begin{array}{c}\text { Stress } \\
\text { (Mpa) }\end{array}$ & $\begin{array}{c}\text { 士Std } \\
\text { Dev }\end{array}$ \\
\hline Schumacher & 0.50 & 870 & 6.11 & 0.36 & 4.36 & 1.10 \\
Diaschumalith F40 & 0.75 & 870 & 6.74 & 0.69 & 5.68 & 0.40 \\
& 0.50 & 980 & 4.32 & 0.46 & 3.28 & 0.43 \\
& 0.75 & 980 & 4.60 & 1.75 & 3.44 & 0.35 \\
\hline Refractron 50/5 & 0.50 & Room & 14.47 & 1.57 & 19.20 & 0.64 \\
with 505 Binder & 0.75 & Room & 15.25 & 1.34 & 18.12 & 2.10 \\
& 1.00 & Room & 15.46 & 1.09 & 17.87 & 1.69 \\
& 1.25 & Room & 15.97 & 1.10 & 18.69 & 1.85 \\
\hline Refractron 70/3 & 0.50 & Room & 16.97 & 1.47 & 19.42 & 1.50 \\
with 442-T Binder & 0.75 & Room & 17.08 & 2.32 & 17.86 & 1.52 \\
& 0.50 & 870 & 16.21 & 1.27 & 17.94 & 0.90 \\
& 0.75 & 870 & 13.15 & 1.70 & 17.49 & 2.27 \\
& 0.50 & 980 & 10.91 & 1.28 & 8.61 & 1.05 \\
& 0.75 & 980 & 9.82 & 1.91 & 8.19 & 0.95 \\
\hline
\end{tabular}



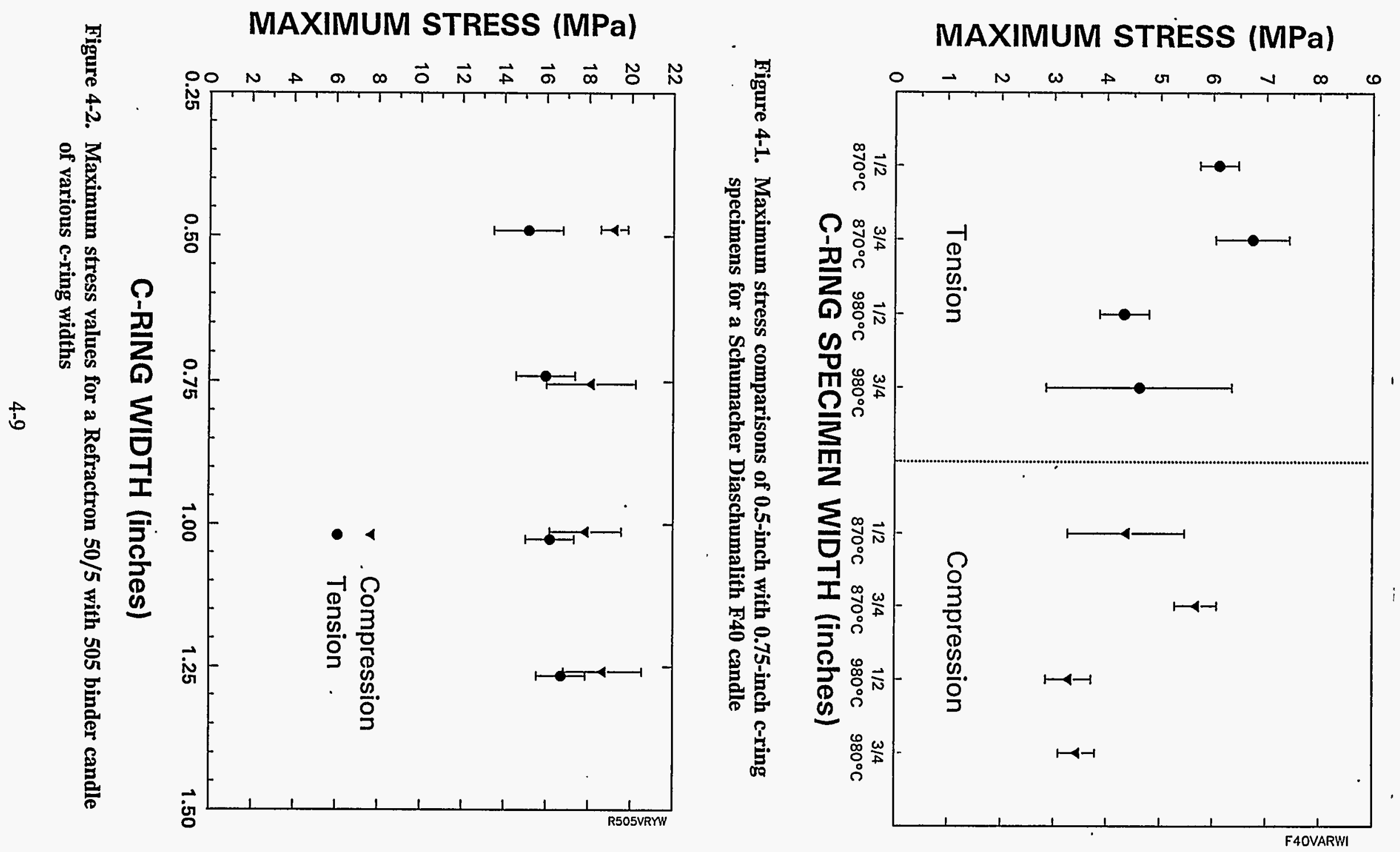


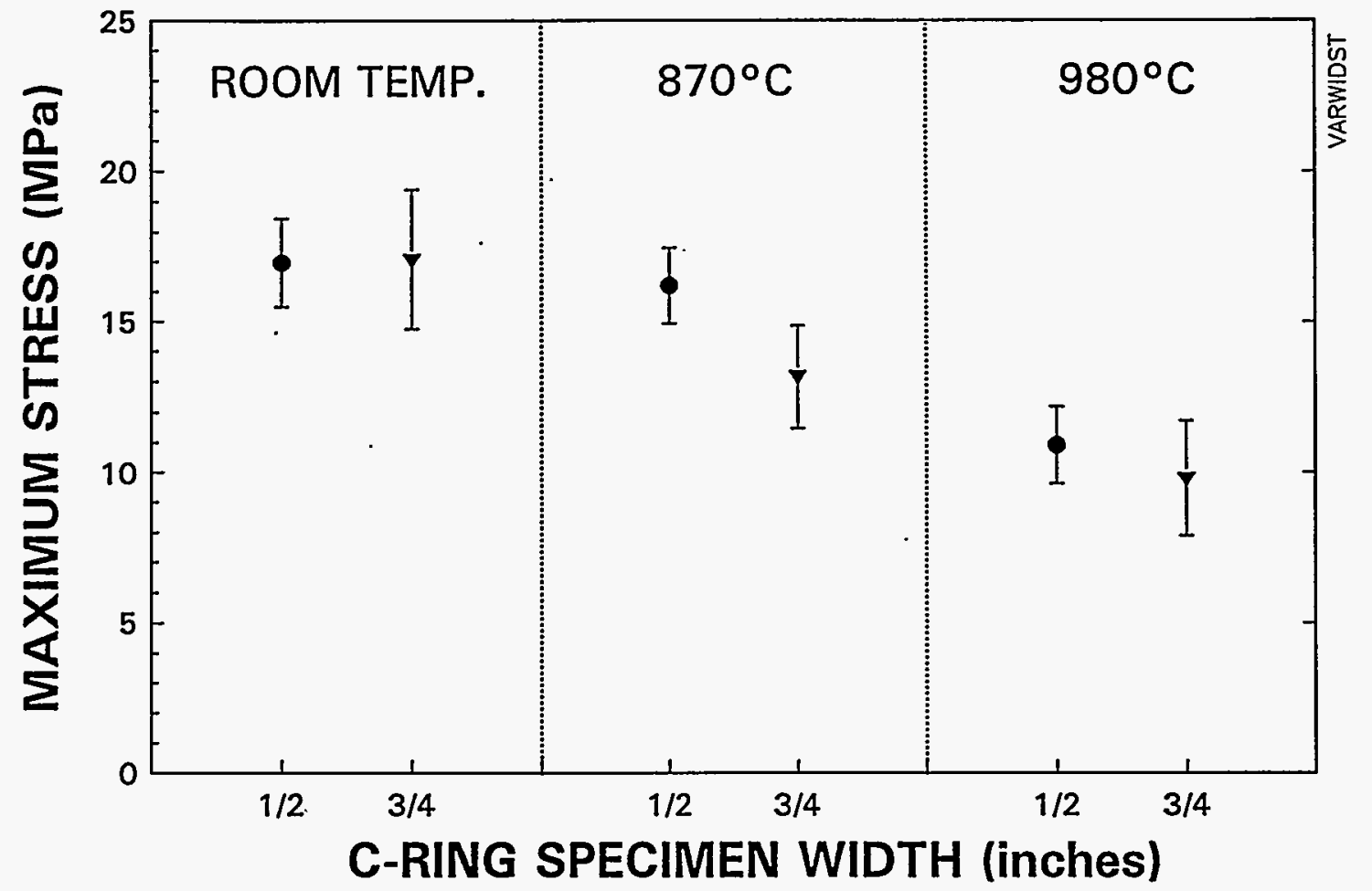

Figure 4-3. Maximum stress comparisons of 0.5-inch with 0.75-inch c-ring tension specimens for a Refractron $70 / 3$ with $442-T$ binder candle

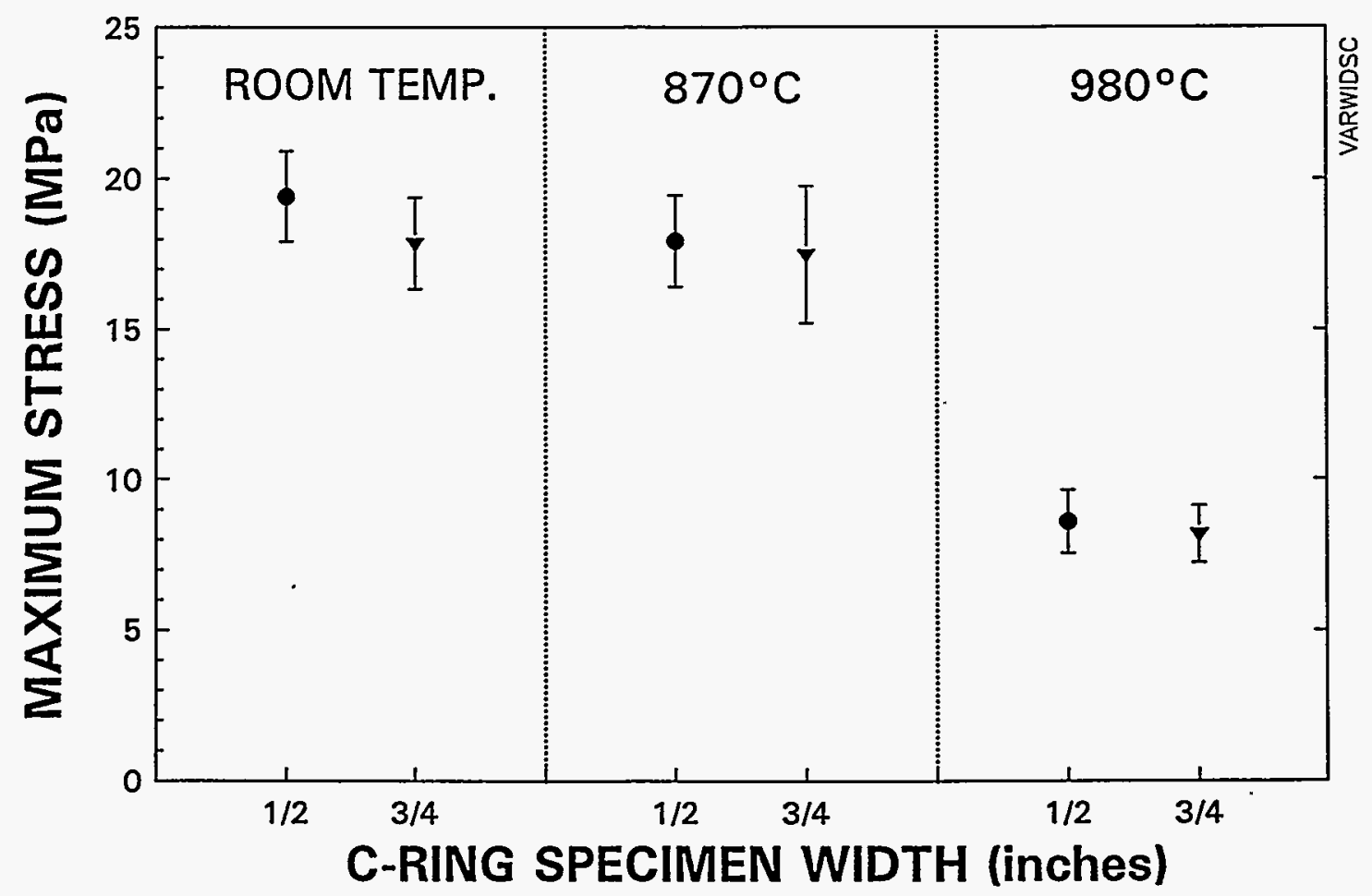

Figure 4-4. Maximum Stress comparisons of 0.5-inch with 0.75-inch c-ring compression specimens for a Refractron $70 / 3$ with $442-T$ binder candle 
values in Figure 4-2 fall within the standard deviations for each respective test (tension and compression), the average maximum stress values seem to be more stable with widths greater than or equal to 0.75 inch. The optimum c-ring width would be 0.75 -in because it would be an inefficient use of material to use c-ring widths greater than 0.75 -in if the 0.75 -in specimens would result in the same maximum stress value. 0.5 -in specimens are acceptable, but they are not desirable because they are more fragile than the larger 0.75 -in specimens. 0.5 -in specimens are also harder to work with at high temperature (during specimen set-up). The slight variability in the 0.5 -in c-ring specimen widths (compared to the larger c-ring widths) may be attributed to the following:

- Edge/surface defects, possibly caused during sample preparation, could have lowered the strength measurements because with a smaller sample volume, the edges would have a greater influence on the sample strength than on a bigger sample volume. This would explain the sometimes lower 0.5 -in strength values.

- Smaller samples might have a lower failure probability and hence will result in higher maximum stress values. This is because smaller samples are less likely to have strengthlowering flaws contained in the smaller sample volume than larger samples. this would explain the sometimes higher 0.5 -in strength values.

The above two strength affecting mechanisms are in conflict with each other and would result in the slight variability of 0.5 -in specimens seen in Figures 4-1 through 4-4.

To investigate the cause of the discrepancy between tension strength and compression strength values due to candle geometry/constituent and not due to the stress equation being used, Acurex Environmental tested an unused homogenous candle made by Didier. The homogenous candle does not have a filtration layer that is different from the supporting body such as the Schumacher and Refractron candles. The Didier candle should have the same strength in c-ring tension as in c-ring compression because the material on the inner surface is the same as on the outer surface. Table 4-8 shows the results from c-ring tests at room temperature (raw data in Appendix D). Figure 4-5 shows graphically that the strength of the material at the inner bore of 
Table 4-8. Maximum stress values for a Didier SiC candle

\begin{tabular}{|l|c|c|c|c|c|c|}
\hline & \multirow{2}{*}{$\begin{array}{l}\text { C-Ring } \\
\text { Width } \\
\text { (inch) }\end{array}$} & \multirow{2}{*}{$\begin{array}{c}\text { Temperature } \\
\left.{ }^{\circ}{ }^{\circ} \mathrm{C}\right)\end{array}$} & \multicolumn{2}{|c|}{ Tension } & \multicolumn{2}{c|}{ Compression } \\
\cline { 5 - 7 } & & $\begin{array}{c}\text { Stress } \\
(\mathrm{Mpa})\end{array}$ & $\begin{array}{c} \pm \text { Std } \\
\text { Dev }\end{array}$ & $\begin{array}{c}\text { Stress } \\
(\mathrm{Mpa})\end{array}$ & $\begin{array}{c} \pm \text { Std } \\
\text { Dev }\end{array}$ \\
\hline Didier SiC & 0.75 & room & 27.13 & 2.41 & 28.22 & 2.35 \\
\hline
\end{tabular}

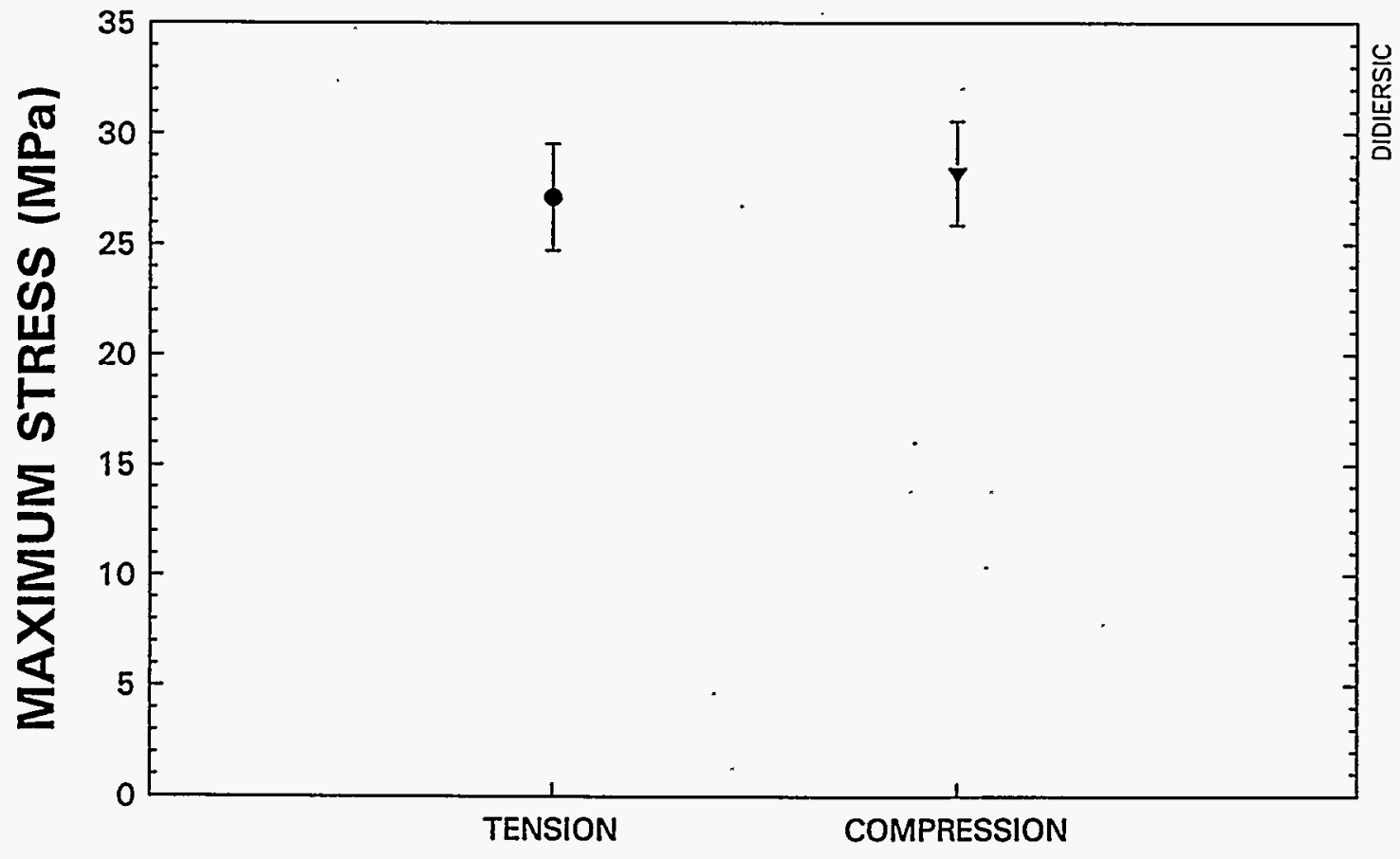

Figure 4-5. Maximum stress comparison of c-ring tension testing with c-ring compression testing for a Didier SiC candle 
the candle (via the tension test) has the same material strength as the material at outer filtration surface (via the compression test). This verifies the use of the stress equation for determining the strength of a material irrespective of the surface being examined.

The higher compression stresses compared to tension (at room temperature), for the Refractron candles are due to the candle design - an outer filtration layer that is denser than the inner supporting body of the candle filter. The denser material will result in a higher strength measurement at room temperature. The lower compression strength at elevated temperatures could be due to the denser material having a lower softening temperature than the less dense inner supporting candle material.

There had been some concern about the machining of the c-rings with a diamond blade saw. Machining processes may be a major contributor to the reliability of ceramic materials. Especially for very dense fine-grained ceramics where flaws created by machining are larger than pre-existing flaws in the material. However, candle filters by nature, are highly porous materials. Coarsegrained materials with uniformly distributed porosity are not affected to any great degree because the size of the flaws created by machining are comparable to or smaller than the existing flaws in the material. ${ }^{9}$ Therefore, to insure that machining does not affect the strength measurements, c-rings were obtained by two different methods as follows:

- Postcut: A section of candle is heated to $1,200^{\circ} \mathrm{C}\left(2,200^{\circ} \mathrm{F}\right)$ for two hours and slowly cooled to room temperature before the candle is cut into $10 \mathrm{c}$-rings ( 5 for tension and 5 for compression testing)

- Precut: A section of candle (from the same candle as the postcut case) is cut into 10 c-rings and then heated to $1,200^{\circ} \mathrm{C}$ (the precut specimens were heat treated at the same time as the postcut specimens).

Chad Sheckler, Product Development Manager of Refractron Technologies Corporation, specified the temperature of $1,200^{\circ} \mathrm{C}$ as appropriate to anneal machined c-rings. If machining does produce strength affecting flaws, then the postcut c-rings (which would retain any built up stresses from 
machining) should be noticeably weaker than the precut c-rings (which would have had some of the internal stresses relieved via the annealing process). Table 4-9 and Figure 4-6 displays the results of this test (raw data in Appendix D).

It can be seen that there is essentially no difference between the precut and postcut c-rings. Hence, machining during c-ring preparation does not significantly affect the strength measurement of the c-rings.

\subsubsection{C-Ring Testing: Thermal Ratcheting}

One of the possible causes of the durability problems encountered by candle filters is thermal shock/thermal fatigue. It has been observed that candles exposed to operating conditions resulted in loss of strength. Acurex Environmental investigated the effect on strength that ambient air pulses have on candles at a elevated temperature. Table 4-10 and Figures 4-7, 4-8, and 4-9 summarizes the tests conducted. The pulsed candles were pulsed 5,000 times with ambient air down the inner bore of the candle while the candle was at $870^{\circ} \mathrm{C}$. Hence, no c-ring compression tests were conducted because if there were to be any strength degradation due to the thermal shock from the ambient air being blown down the inner bore of the candle, then it would be most apparent in tests examining the inner surface of the candle (c-ring tension).

The unused candles have no history of pulse cleaning nor of temperature cycling. It can be seen that the Schumacher and IFP LayCer candles pulsed with time durations of 0.5 seconds exhibit room temperature strength loss. The strength loss due to these pulses can be attributed to thermal shock in which temperature gradients produce stresses under conditions that restrain the free expansion of a body (candle). The temperature distribution could be such that free expansion of each volume element would separate the individual volume elements in such a way that they would not fit together. If the maximum stress for a material is reached, failure (such as cracking and spalling) will result. The effect of thermal stresses depends not only on the absolute level of stresses, but also the stress distribution, stress duration, and material characteristics (such as ductility, homogeneity, porosity, and presence of pre-existing flaws). ${ }^{10}$ 
Table 4-9. Maximum stress values for an unused Refractron $50 / 5$ with 505 binder that had c-rings cut before and after heat treatment at $1,200^{\circ} \mathrm{C}$

\begin{tabular}{|l|c|c|c|c|c|c|}
\hline & \multirow{2}{*}{$\begin{array}{l}\text { C-Ring } \\
\text { Width } \\
\text { (inch) }\end{array}$} & \multirow{2}{*}{$\begin{array}{c}\text { Temperature } \\
{ }^{\circ} \mathbf{C} \text { C) }\end{array}$} & \multicolumn{2}{|c|}{ Tension } & \multicolumn{2}{c|}{ Compression } \\
\cline { 4 - 7 } & & $\begin{array}{c}\text { Stress } \\
(\text { Mpa) }\end{array}$ & $\begin{array}{c} \pm \text { Std } \\
\text { Dev }\end{array}$ & $\begin{array}{c}\text { Stress } \\
(\text { Mpa) }\end{array}$ & $\begin{array}{c} \pm \text { Std } \\
\text { Dev }\end{array}$ \\
\hline Postcut & 0.75 & room & 12.52 & 1.56 & 15.46 & 2.24 \\
Precut & 0.75 & room & 11.68 & 1.60 & 13.20 & 0.81 \\
\hline
\end{tabular}

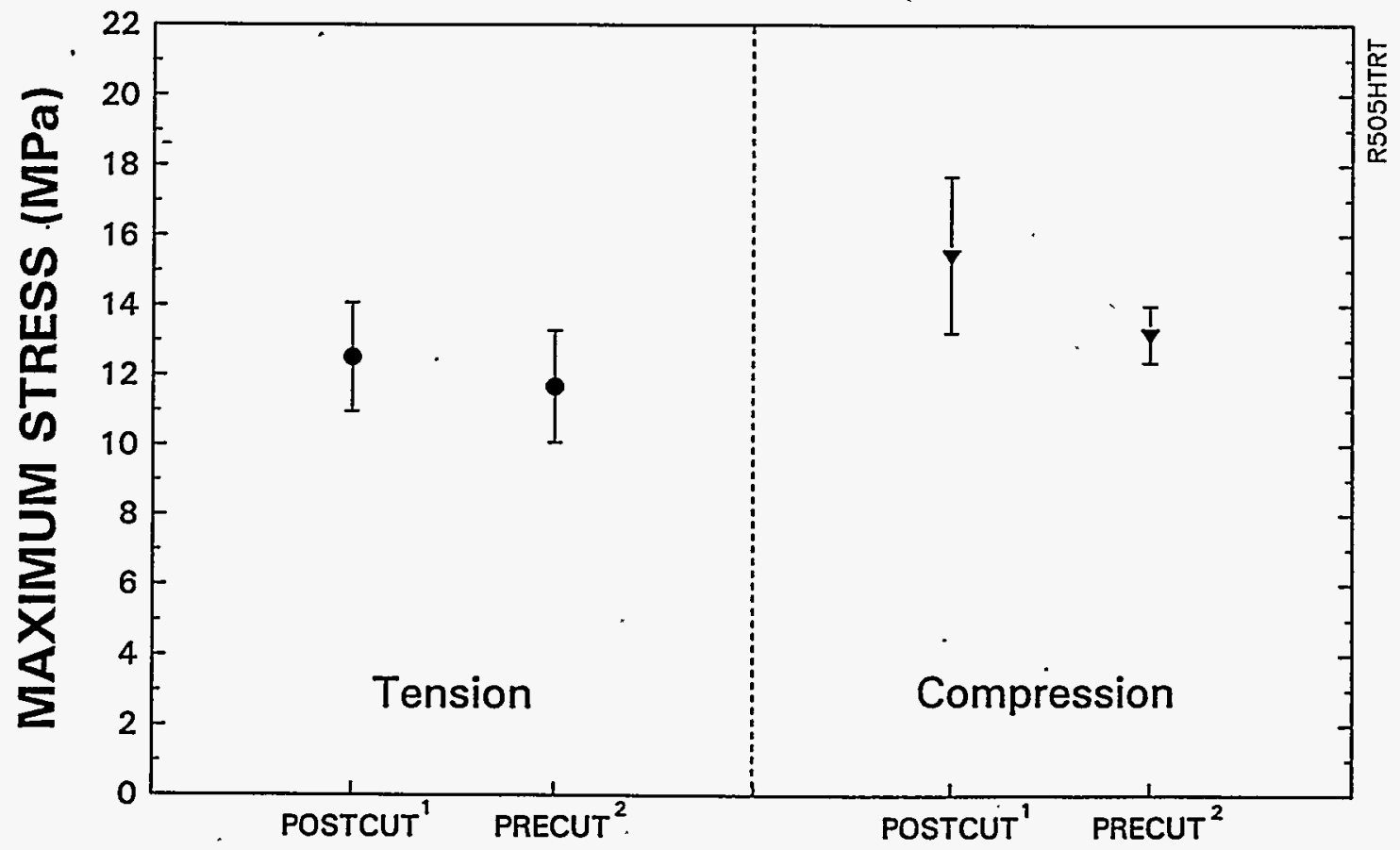

${ }^{1}$ Heated to $1200^{\circ} \mathrm{C}$, then cut into C-rings

${ }^{2}$ Cut into $\mathrm{C}$-rings, then heated to $1200^{\circ} \mathrm{C}$

Figure 4-6. Maximum stresses of a heat treated Refractron 50/5 with 505 binder candle c-rings to determine the effect of machining 
Table 4-10. Maximum stress summary of c-ring tension tests investigating the effect of 5,000 ambient air pulses on candles at $870^{\circ} \mathrm{C}$

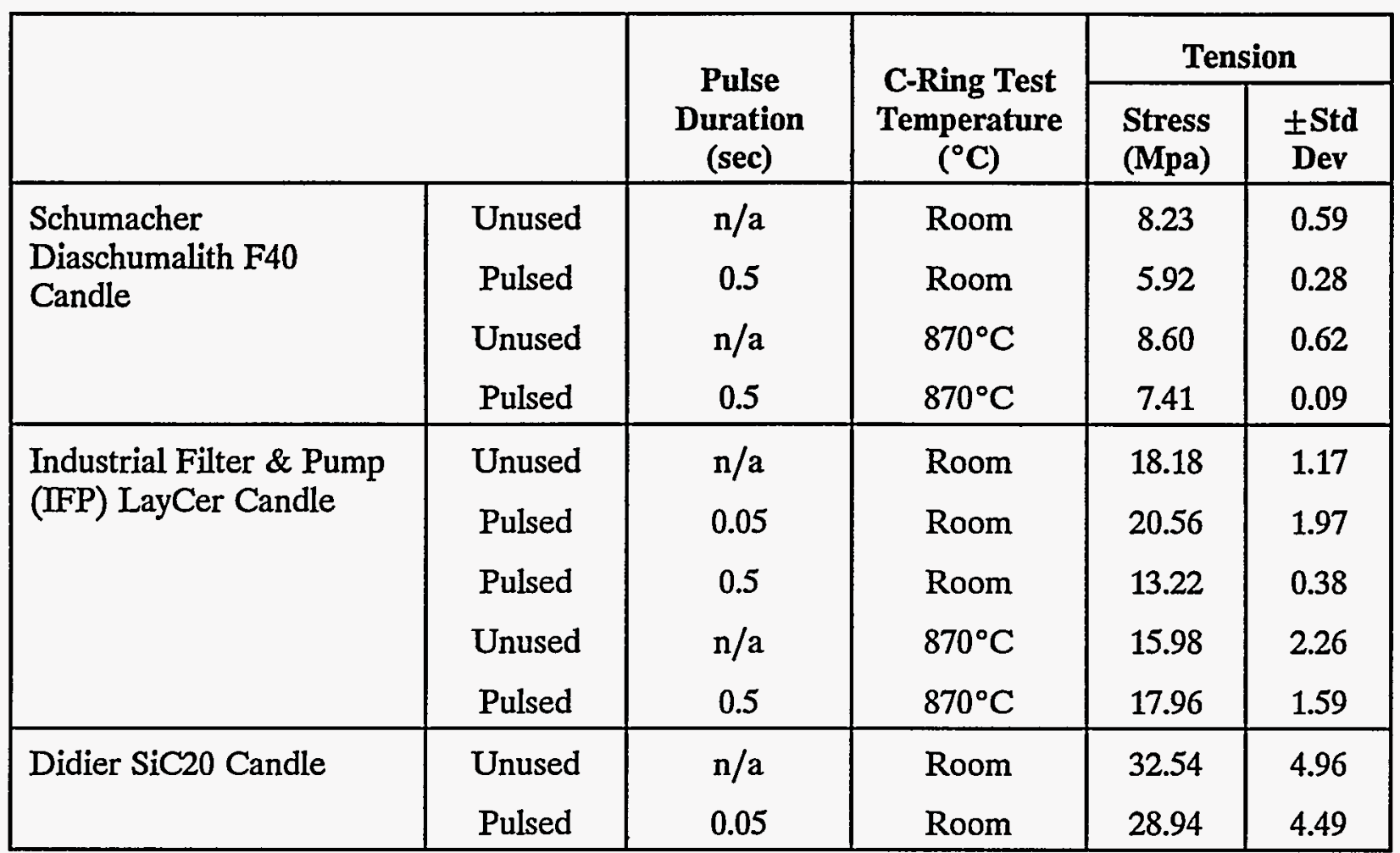

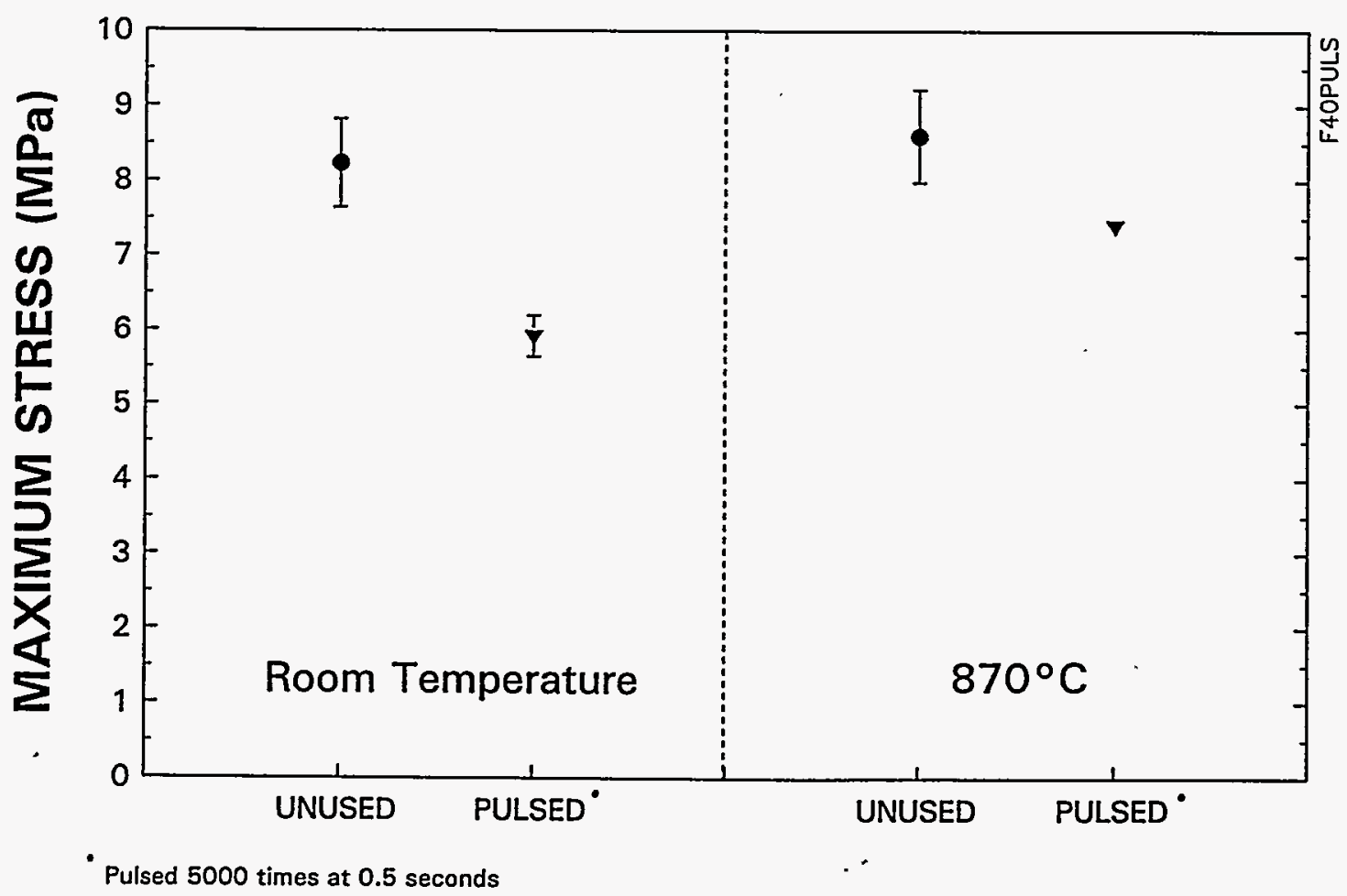

Figure 4-7. C-ring tension test results of a Schumacher Diaschumalith F40 candle pulsed 5,000 times with ambient air while at $870^{\circ} \mathrm{C}$ 


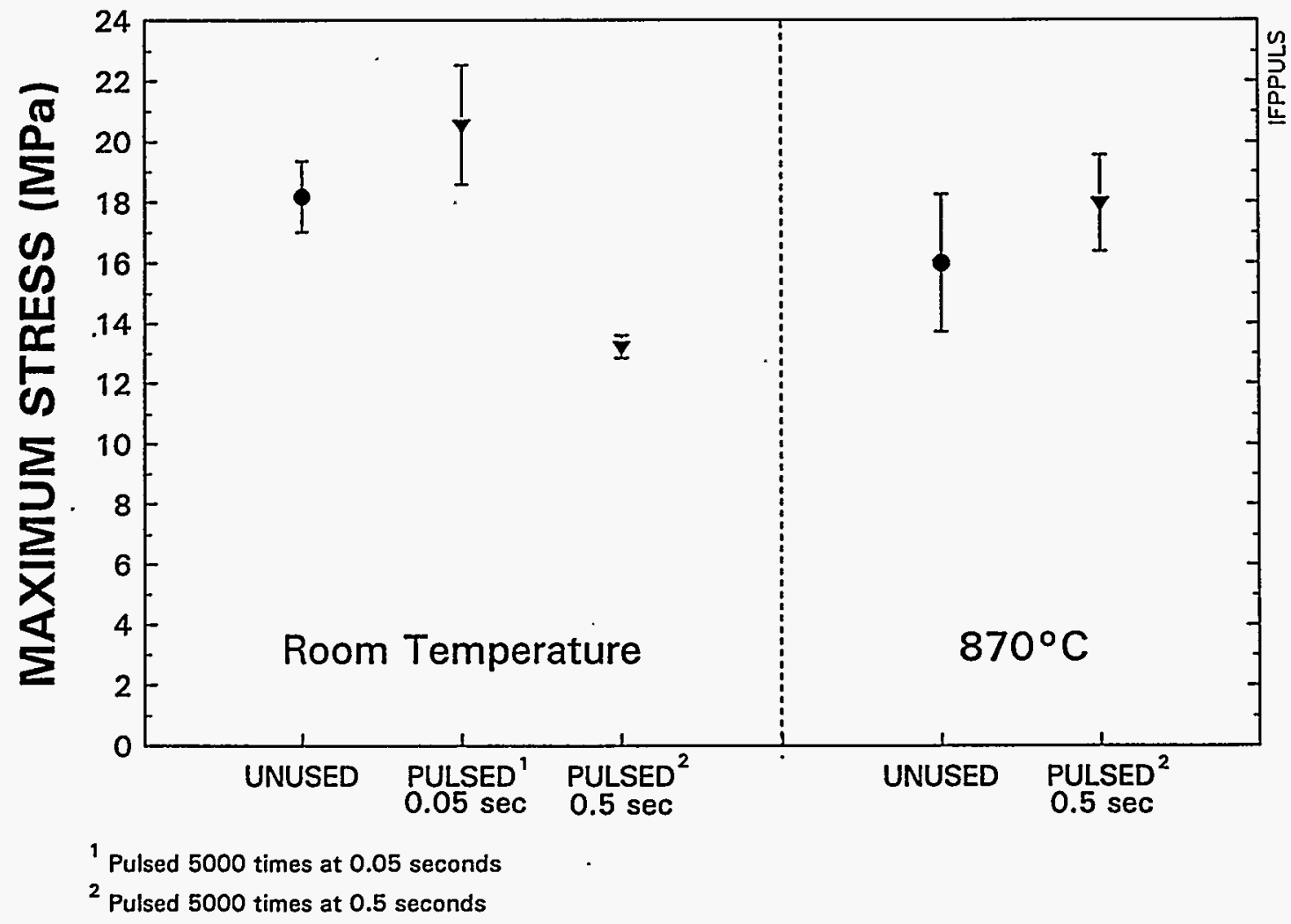

Figure 4-8. C-ring tension test results of an IFP LayCer candle pulsed 5,000 times with ambient air while at $870^{\circ} \mathrm{C}$

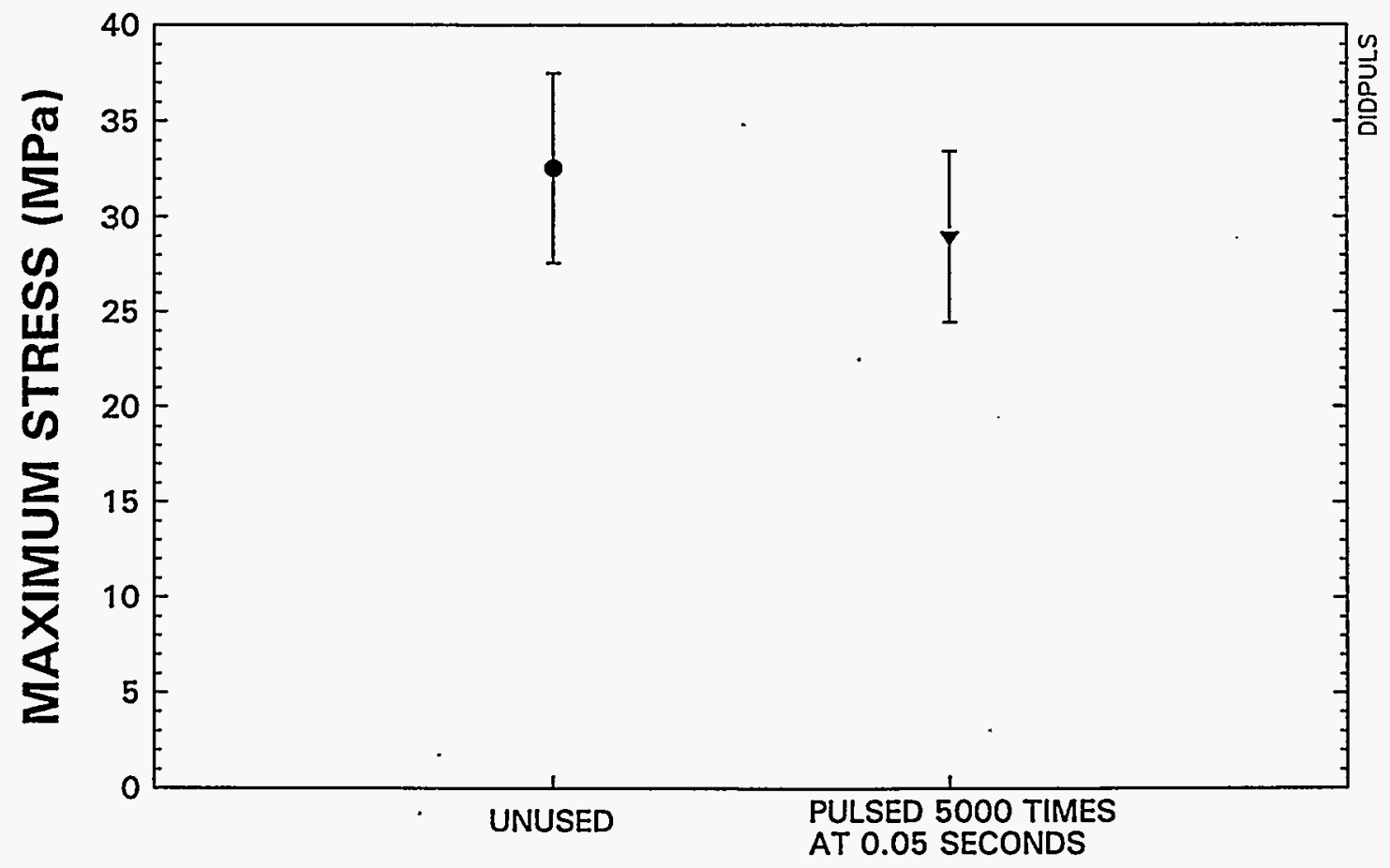

Figure 4-9. Room temperature c-ring tension test results of a Didier SiC20 candle pulsed 5,000 times with ambient air while at $870^{\circ} \mathrm{C}$ 
As a control, the unused candles (in Figure 4-7 and 4-8) tested at high temperature resulted in stress values within the range of room temperature tests of the same unused candles. This suggests that the elevation of temperature will not affect the strength of c-ring specimens if there is no change in the surface characteristics of the candle. The control also acts as a reference to which strength values from exposed candles can be compared.

With stress duration also being a determining factor, it can be seen that the IFP LayCer and Didier candles pulsed at a time duration of 0.05 seconds (refer to Figures 4-8 and 4-9) do not show any room temperature strength loss (the averages are within the breadth of their standard deviations). This series of room temperature tension test comparisons do imply that ambient air pulses to candles at operating temperatures cause strength degradation (possibly via micro-cracking on the inner bore of the candle) when the pulse duration is at least 0.5 seconds.

An interesting aspect exhibited in Figures 4-7 and 4-8 is that at high temperature, the candles that showed strength loss (due to 0.5 second pulse durations) when tested at room temperature show improved strength (some to the point of being within the \pm 1 standard deviation range for the unused candles). A possible explanation for this "healing" behavior is that the binder holding the $\mathrm{SiC}$ particles together is softening (increased ductibility) and thereby recovering the base toughness of the candles at high temperature. A more ductile material has a larger plastic deformation energy value that dominates the high temperature fracture process and will result in increasing the critical strain-energy-release rate (also referred to as the critical crack driving force). This increases the strength because the stress at the crack tip is relieved by viscous deformation which reduces the stress at the crack tip. This also increases the critical stress value because a greater applied load is required to cause failure. ${ }^{11,12}$ The raw data for this series of tests can be found in Appendix C.

\subsubsection{C-Ring Testing: Thermal Exposure Specimens}

The summary of all c-ring tests on the Schumacher candle specimens and the Refractron candle specimens from the long term thermal exposure testing series are presented in Tables 4-11 
Table 4-11. C-ring test results summary of Schumacher candles used in the long term thermal exposure tests

\begin{tabular}{|c|c|c|c|c|c|c|c|c|c|c|c|c|c|}
\hline \multicolumn{2}{|c|}{ Less than 5 specimens available for testing } & \multirow{2}{*}{\multicolumn{6}{|c|}{ C-RING TENSION TESTING }} & & & & & \multicolumn{2}{|c|}{ tetsumry } \\
\hline & \multirow{4}{*}{$\begin{array}{l}\text { C-ring } \\
\text { Width } \\
\text { (inches) }\end{array}$} & & & & & & & \multicolumn{6}{|c|}{ C-RING COMPRESSION } \\
\hline \multirow[t]{3}{*}{ CANDLE DESCRIPTION } & & \multirow{2}{*}{\multicolumn{2}{|c|}{\begin{tabular}{|c|c|}
\multicolumn{2}{|c|}{ Room } \\
Stress \pm Std
\end{tabular}}} & \multicolumn{2}{|c|}{$870^{\circ} \mathrm{C}$} & \multicolumn{2}{|c|}{$980^{\circ} \mathrm{C}$} & \multicolumn{2}{|c|}{ Room Tomp } & \multicolumn{2}{|c|}{$870^{\circ} \mathrm{C}$} & \multicolumn{2}{|c|}{$980^{\circ} \mathrm{C}$} \\
\hline & & & & Stress & \pm Std & Stress & \pm Std & Stress: & $\pm S t d$ & Stress & \pm Std & Stress & \pm Std \\
\hline & & (MPa) & Dev & $(\mathrm{MPa})$ & Dev & $(\mathrm{MPa})$ & Dev & $(\mathrm{MPa})$ & Dev & $(\mathrm{MPa})$ & Dov & $(\mathrm{MPa})$ & Dev \\
\hline SCHUMACHER DIASCHUMALITH & & & & & & & & & & & & & \\
\hline & & & & & & & & & & & & & \\
\hline F40 CANDLE & & & & & & & & & & & & & \\
\hline & & & & & & & & & & & & & \\
\hline UNUSED & & & & & & & & & & & & & \\
\hline SOLAR (early 1991) & $3 / 4^{\prime \prime}$ & 5.17 & 0.55 & & & 4.43 & 0.24 & 4.59 & 0.31 & & & 3.56 & 0.23 \\
\hline SOLAR (late 1991) (vary width) & $3 / 4^{\prime \prime}$ & & & 6.74 & 0.69 & 4.60 & 4,75 & & & 5,68 & 0.40 & 3.44 & $\overline{0.35}$ \\
\hline SOLAR (late 1991) (vary width) & $1 / 2^{n}$ & & & 6,11 & 0.36 & $4: 32$ & 0.46 & & & 8,36 & 110 & 3.28 & 0.43 \\
\hline & & & & & & & & & & & & & \\
\hline & & & & & & & & & & & & & \\
\hline & & & & & & & & & & & & & \\
\hline EXPOSURE TESTING & & & & & & & & & & & & & \\
\hline & & & & & & & & & & & & & \\
\hline Control: $500 \mathrm{hrs}$ at $870^{\circ} \mathrm{C}$ only & $1 / 2^{*}$ & & & 7,92 & 101 & & & & & 4.49 & 1807 & & \\
\hline & & & & & & & & & & & & & \\
\hline $95 \mathrm{ppm} \mathrm{NaCl} / 20 \% \mathrm{H} 2 \mathrm{O} / 870^{\circ} \mathrm{C}$ & & & & & & & & & & & & & \\
\hline $100 \mathrm{hr} /$ No Pulse $(A)$ & $1 / 2^{n}$ & & & 4.85 & 0.33 & & & & & 3,93 & 0.59 & & \\
\hline & & & & & & & & & & & & & \\
\hline $65 \mathrm{ppm} \mathrm{NaCl} / 20 \% \mathrm{H} 2 \mathrm{O} / 980^{\circ} \mathrm{C}$ & & & & & & & & & & & & & \\
\hline $100 \mathrm{hr} /$ Pulse (B) & $1 / 2^{n}$ & & & & & 1.79 & 0.73 & & & & & 1.29 & 0.21 \\
\hline 475hr/Pulse (C) & $1 / 2^{11}$ & & & & & 2.69 & 0.45 & & & & & 298 & 112 \\
\hline 575hr/Pulse (D) & $1 / 2^{n}$ & & & & & 2.51 & 0.25 & & & & & 2146 & 0.30 \\
\hline & & & & & & & & & & & & & \\
\hline $20 \mathrm{ppm} \mathrm{NaCl} / 15 \% \mathrm{H} 2 \mathrm{O} / 870^{\circ} \mathrm{C}$ & & & & & & & & & & & & & \\
\hline $100 \mathrm{hr} /$ Pulse (E) & $1 / 2^{\prime \prime}$ & & & 5.72 & 0,39 & & & & & $4: 07$ & 0,97 & & \\
\hline 400hr/Pulse (F) & $1 / 2^{\prime \prime}$ & & & 4.76 & 2.14 & & & & & 4,22 & $0 ; 53$ & & \\
\hline 500hr/Pulse (G) & $1 / 2^{n}$ & & & 8.43 & 0.54 & & & & & 5.01 & 0.79 & & \\
\hline 1000hr/Pulse (H) & $1 / 2^{\prime \prime}$ & & & $4: 64$ & 0.01 & & & & & 3.37 & 0.26 & & \\
\hline & & & $\cdot$ & & & & & & & & & & \\
\hline & & & & & & & & & & & & & \\
\hline & & & & & & & & & & & & & \\
\hline & & & & & & & & & & & & & \\
\hline
\end{tabular}


and 4-12, respectively. All of the raw c-ring data can be found in Appendix D. Figures 4-10 through 4-19 are the graphical representations of the c-ring data in Tables 4-11 and 4-12. Figures 4-10 through 4-14 are of the 0.50 inch Schumacher Diaschumalith F40 candle c-ring specimen strengths in Table 4-11. Figures 4-15 through 4-19 are of the 0.50 inch c-ring specimen data in Table 4-12 of the Refractron 70/3 with 442-T binder candle.

In Figure 4-10, there is no change in c-ring compression strength between 100 hours of exposure at $95 \mathrm{ppm} \mathrm{NaCl}, 20 \%$ steam, and $870^{\circ} \mathrm{C}$ (no pulse cleaning) with an unused Schumacher candle. This implies that there is no change in strength to the outer surface with exposure. There is about a $20 \%$ drop in strength from an unused candle when the candle is tested in tension. The drop in strength could not be attributed to pulse cleaning because this exposure test did not include any pulse cleaning. Because this was the first candle tested in the long term thermal exposure testing system, it is possible that thermal shock or other mechanical damage to the candle could have occurred because there were problems with the testing system at the beginning of testing which led to many shut down episodes.

Figure 4-11 shows a 40 to $60 \%$ drop in strength for the 100-, 475-, and 575-hr Schumacher specimens exposed to $65 \mathrm{ppm} \mathrm{NaCl}, 20 \%$ steam, and $980^{\circ} \mathrm{C}$ tested in c-ring tension. Figure 4-12 shows a 55 to $60 \%$ drop in strength for the 100 - and 575-hr specimens tested in c-ring compression, but no significant drop in strength for the $475-\mathrm{hr}$ specimen. The 575 -hr candle specimen was situated near the rear of the vessel, and the 100- and 475-hr specimens were placed near the front of the vessel (not simultaneously). The tension test appears to confirm the strength degradation due to thermal shock from pulse cleaning theory, but the compression test results appears inconclusive.

There is no significant change in strength of all the Schumacher exposure candles tested at $20 \mathrm{ppm} \mathrm{NaCl}, 15 \%$ steam, and $870^{\circ} \mathrm{C}$ when tested in c-ring compression (refer to Figure 4-14). Figure 4-13 shows no significant difference in strength for the c-ring tension tests of the 100-and $400-\mathrm{hr}$ exposure specimens. However, there is a $25 \%$ decrease in strength for the $1,000-\mathrm{hr}$ specimen 
Table 4-12. C-ring test results summary of Refractron candles used in the long term thermal exposure tests Less than 5 specimens available for festing

CANDLE DESCRIPTION

\begin{tabular}{|c|c|c|c|c|c|c|c|c|c|c|c|c|c|}
\hline \multirow{4}{*}{ CANDLE DESCRIPTION } & \multirow{4}{*}{$\begin{array}{c}\text { C-ring } \\
\text { Width } \\
\text { (inches) }\end{array}$} & \multicolumn{6}{|c|}{ C-RING TENSION TESTING } & \multicolumn{6}{|c|}{ C-RING COMPRESSION } \\
\hline & & \multirow{2}{*}{\multicolumn{2}{|c|}{\begin{tabular}{|l|l|} 
Room Temp \\
Stress \pm Std \\
\end{tabular}}} & \multicolumn{2}{|c|}{$870^{\circ} \mathrm{C}$} & \multicolumn{2}{|c|}{$980^{\circ} \mathrm{C}$} & \multirow{2}{*}{\multicolumn{2}{|c|}{\begin{tabular}{|l||} 
Room Temp \\
Stress \\
Std
\end{tabular}}} & \multicolumn{2}{|c|}{$870^{\circ} \mathrm{C}$} & \multicolumn{2}{|c|}{$980^{\circ} \mathrm{C}$} \\
\hline & & & & Stress: & $\pm S t d$ & Stress & \pm Std & & & Stress: & $\pm \mathrm{Std}$ & Stress: & $\pm \mathrm{Std}$ \\
\hline & & $(\mathrm{MPa})$ & Dev & $(\mathrm{MPa})$ & Dev & $(\mathrm{MPa})$ & Dev & (MPa) & Dev & $(\mathrm{MPa})$ & Dev & (MPa) & Dev \\
\hline \multicolumn{14}{|l|}{ REFRACTRON } \\
\hline & & & & & & & & & & & & & \\
\hline \multicolumn{14}{|l|}{ 50/5 WITH 505 BINDER CANDLE } \\
\hline & & & & & & & & & & & & & \\
\hline \multicolumn{14}{|l|}{ EXPOSURE TESTING } \\
\hline \multicolumn{14}{|l|}{$20 \mathrm{ppm} \mathrm{NaCl} / 15 \% \mathrm{H} 2 \mathrm{O} / 870^{\circ} \mathrm{C}$} \\
\hline \multirow[t]{3}{*}{ 100hr/Pulse ( $\$$ ) } & $1 / 2^{n}$ & & & 13.72 & 144 & & & & & 13,85 & 0.41 & & \\
\hline & & & & & & & & & & & & & \\
\hline & & & & & & & & & & & & & \\
\hline \multirow{2}{*}{\multicolumn{14}{|c|}{ 70/3 w/442-T BINDER CANDLE }} \\
\hline & & & & & & & & & & & & & \\
\hline \multicolumn{14}{|l|}{ UNUSED } \\
\hline Varying width test $0.50^{n}(2 / 93)$ & $1 / 2^{n}$ & 16.97 & 1.47 & 16.21 & 1.27 & 10.91 & 1.28 & 19.42 & 1.50 & 17.94 & 0.90 & 8.61 & 1.05 \\
\hline \multirow[t]{2}{*}{ Varying width test $0.75^{\prime \prime}(2 / 93)$} & $3 / 4^{\prime \prime}$ & 17.08 & 2.32 & 13.15 & 1.70 & 9.82 & 1.91 & 17.86 & 1.52 & 17.49 & 2.27 & 8.19 & 0.95 \\
\hline & & & & & & & & & & & & & \\
\hline & & & & & & & & & & & & & \\
\hline \multicolumn{14}{|l|}{ EXPOSURE TESTING } \\
\hline & & & & & & & & & & & & & \\
\hline \multicolumn{14}{|l|}{$20 \mathrm{ppm} \mathrm{NaCl} / 15 \% \mathrm{H} 2 \mathrm{O} / 870^{\circ} \mathrm{C}$} \\
\hline 100hr/No Pulse/Front (l) & $1 / 2^{\prime \prime}$ & & & 15.96 & 0.15 & & & & & 16.64 & 177 & & \\
\hline 100hr/No Pulse/Rear (i) & $1 / 2^{n}$ & & & 16.61 & 4,35 & & & & & 16.36 & 0,72 & & \\
\hline 100hr/Pulse $(\mathrm{J})$ & $1 / 2^{n}$ & & & 13,85 & 0.87 & & & & & 16,60 & 1,13 & & \\
\hline 400hr/Pulse (K) & $1 / 2^{\prime \prime}$ & & & 11.97 & 1,65 & & & & & $12 ; 14$ & 0.68 & & \\
\hline 500hr/Pulse (L) & $1 / 2^{n}$ & & & 15.36 & 1.40 & & & & & $9 ; 10$ & 1,45 & & \\
\hline \multirow[t]{2}{*}{ 1000hr/ Pulse (M) } & $1 / 2^{n}$ & & & 18.96 & 3,51 & & & & & \%.20 & 2,16 & & \\
\hline & & & & & & & & & & & & & \\
\hline \multicolumn{14}{|l|}{$20 \mathrm{ppm} \mathrm{NaCl} / 15 \% \mathrm{H} 2 \mathrm{O} / 980^{\circ} \mathrm{C}$} \\
\hline $100 \mathrm{hr} /$ Pulse $(\mathrm{N})$ & $1 / 2^{\prime \prime}$ & & & & 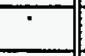 & 8.52 & 0.64 & & & & & 5.76 & 0.67 \\
\hline $400 \mathrm{hr} / \mathrm{Pulse}(\mathrm{O})$ & $1 / 2^{\prime \prime}$ & & & & & $2.28:$ & 0.67 & & & & & 1.72 & 0.34 \\
\hline 500hr/Pulse (P) & $1 / 2^{\prime \prime}$ & & & & & 1.68 & 0.17 & & & & & 1.17 & 0.20 \\
\hline 1000hr/Pulse (Q) & $1 / 2^{n}$ & & & & & 2.32 & 0.64 & & & & & 2.31 & 0.93 \\
\hline & & & & & & & & & & & & & \\
\hline
\end{tabular}




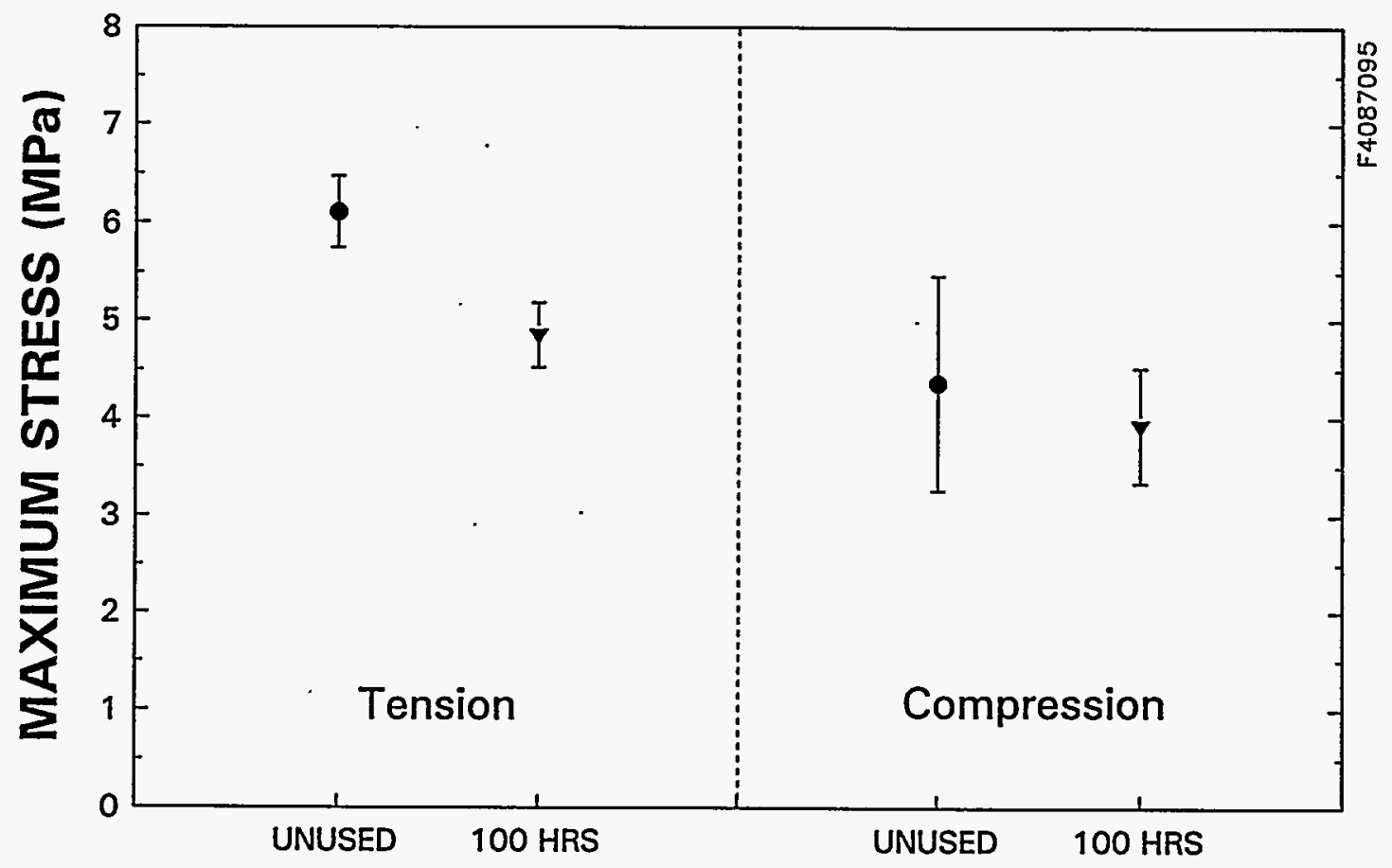

Figure 4-10. Schumacher Diaschumalith F40 candle exposed to $95 \mathrm{ppm} \mathrm{NaCl}$ and $20 \%$ steam at $870^{\circ} \mathrm{C}$ (no pulse cleaning): c-ring tested at $870^{\circ} \mathrm{C}$

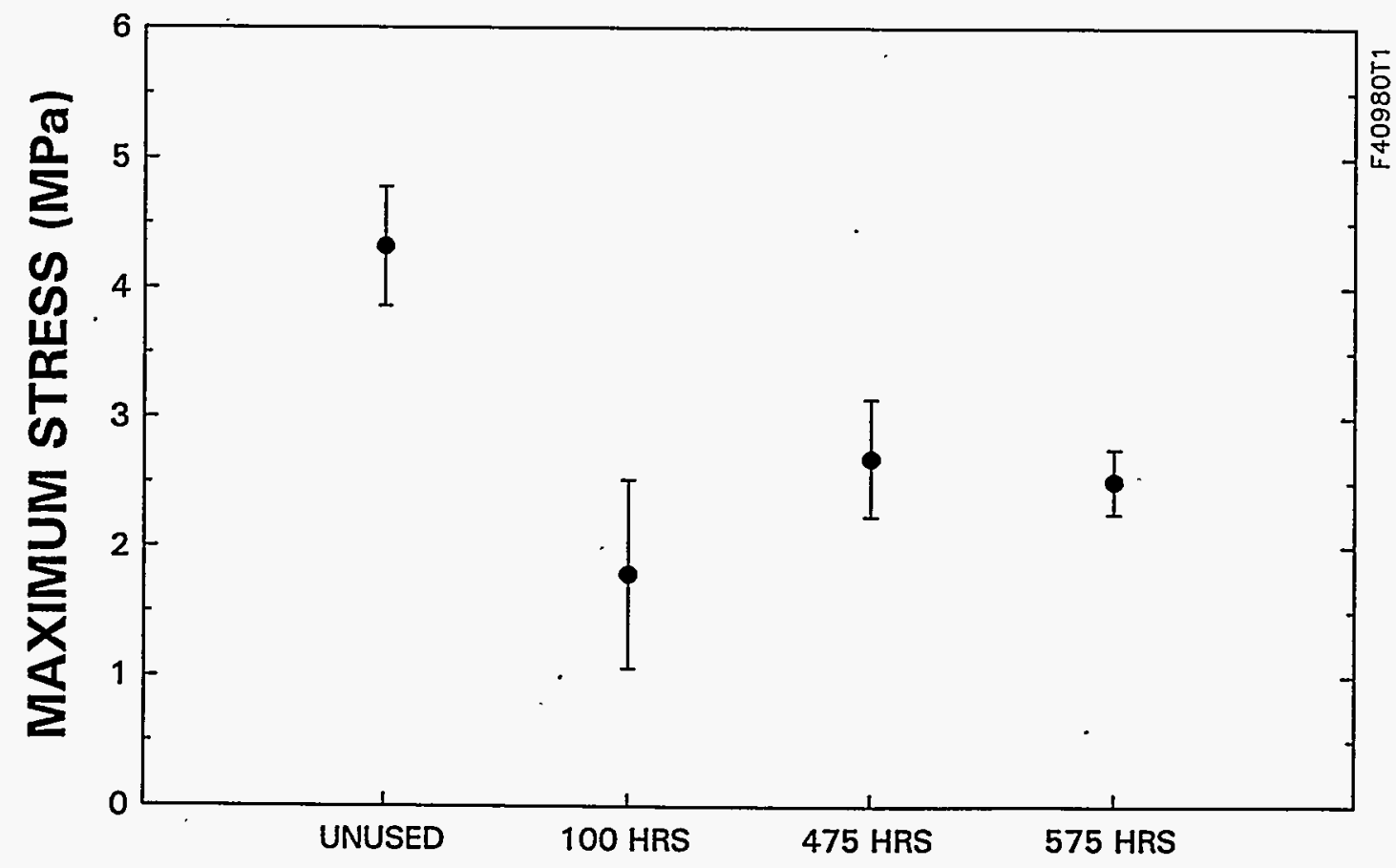

Figure 4-11. Schumacher Diaschumalith F40 candle exposed to $65 \mathrm{ppm} \mathrm{NaCl}$ and $20 \%$ steam at $980^{\circ} \mathrm{C}$ : c-ring tension test at $980^{\circ} \mathrm{C}$ 


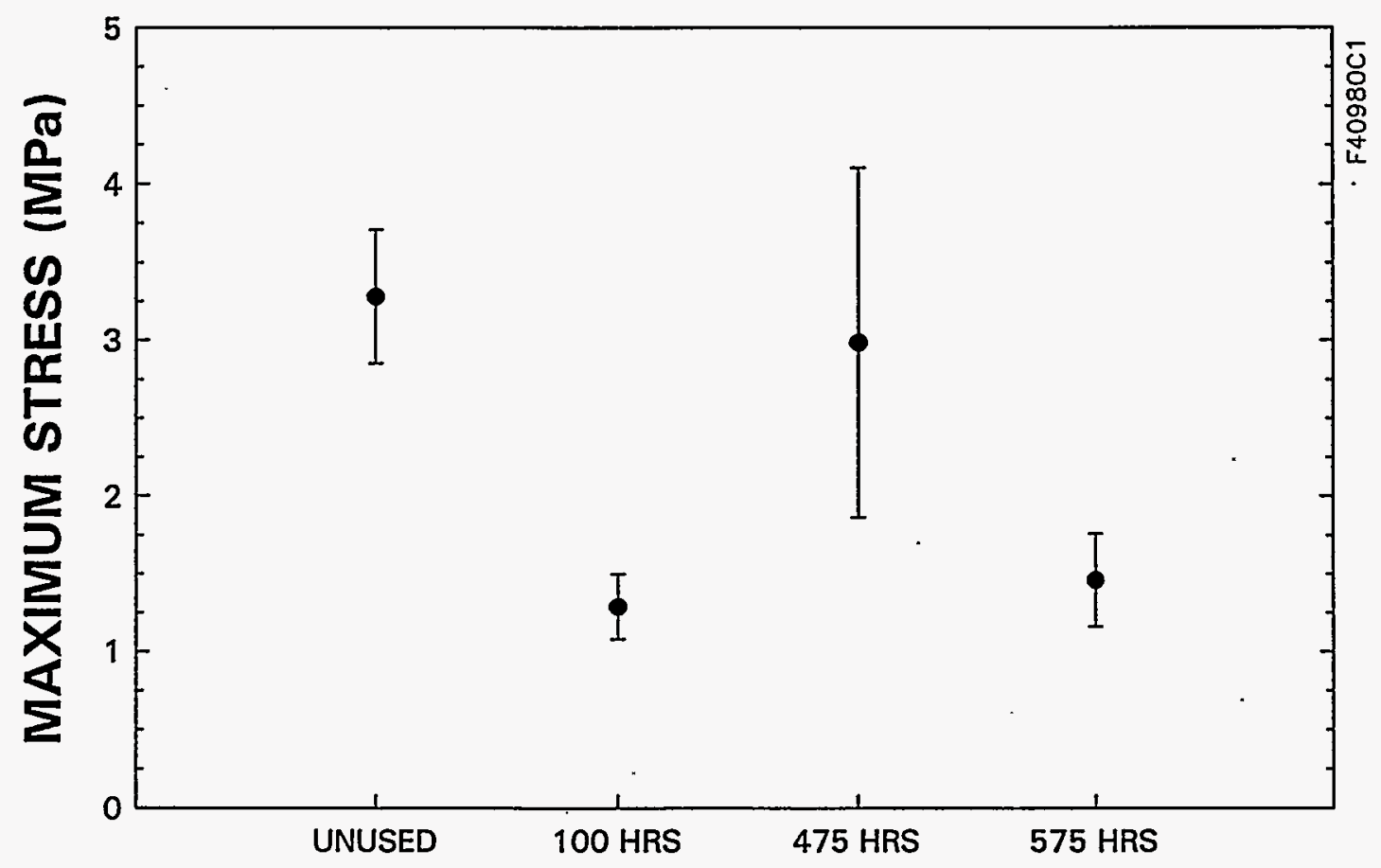

Figure 4-12. Schumacher Diaschumalith F40 candle exposed to $65 \mathrm{ppm} \mathrm{NaCl}$ and $20 \%$ steam at $980^{\circ} \mathrm{C}$ : c-ring compression test at $980^{\circ} \mathrm{C}$

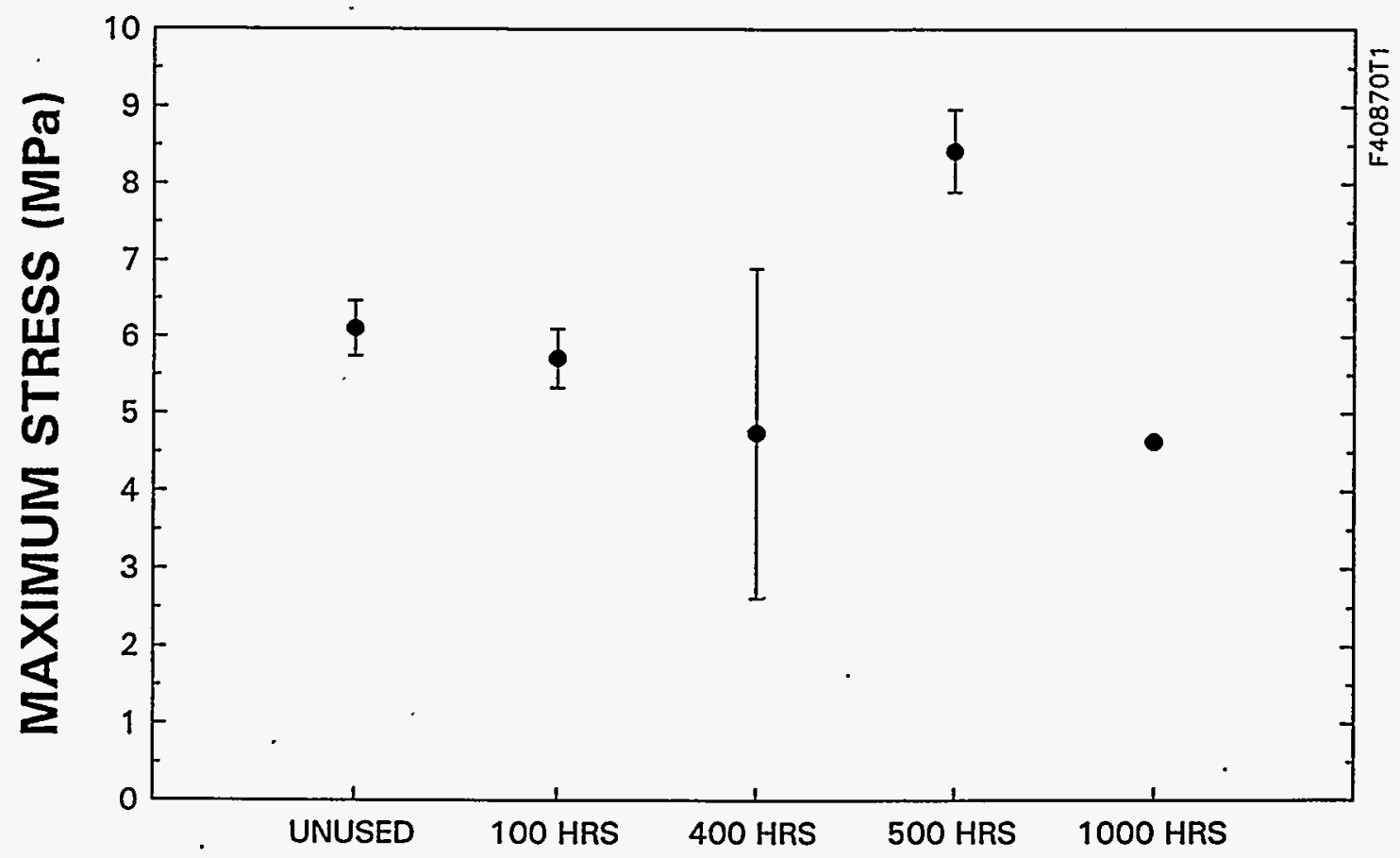

Figure 4-13. Schumacher Diaschumalith F40 candle exposed to $20 \mathrm{ppm} \mathrm{NaCl}$ and $15 \%$ steam at $870^{\circ} \mathrm{C}$ : c-ring tension test at $870^{\circ} \mathrm{C}$ 


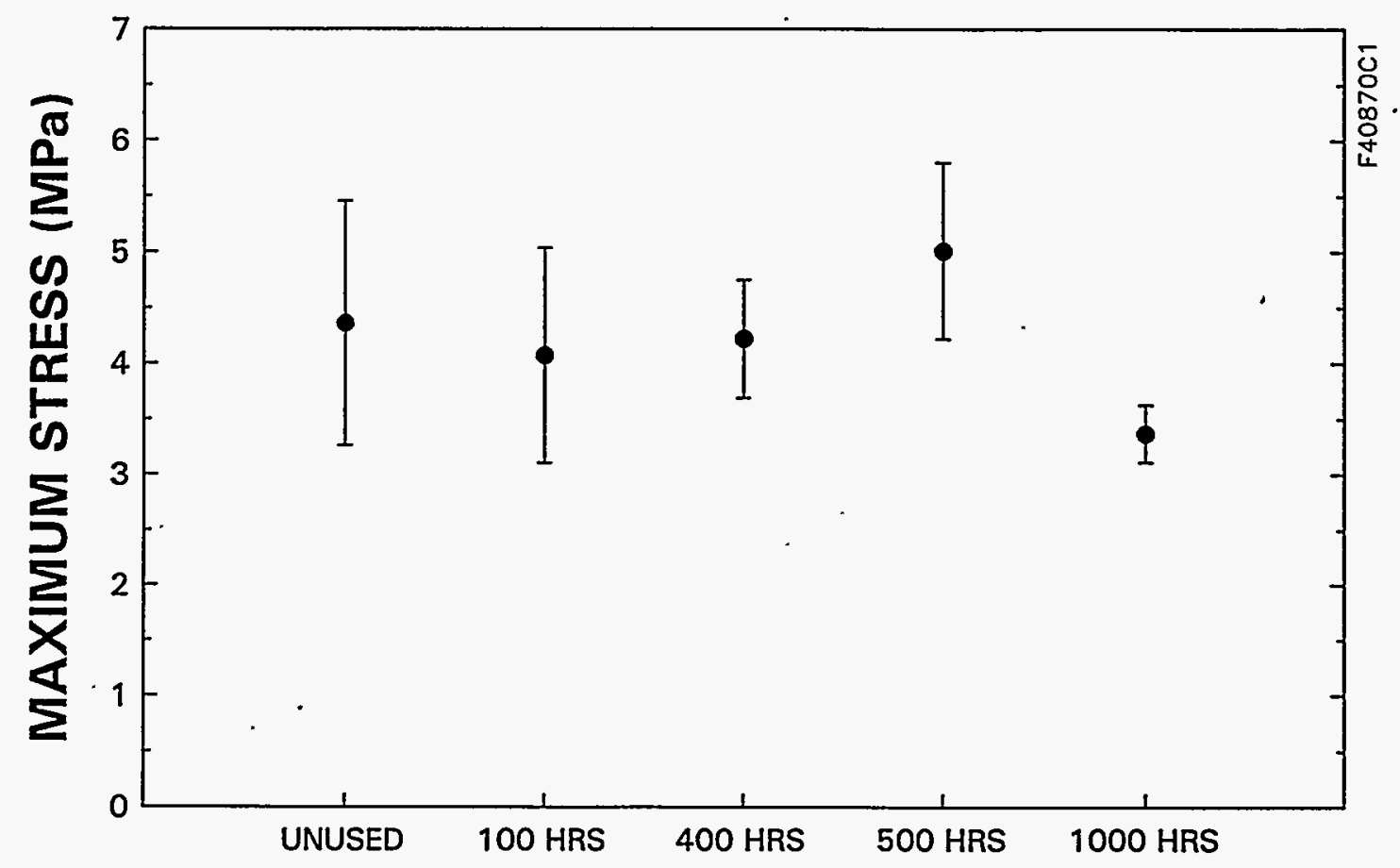

Figure 4-14. Schumacher Diasschumalith $\mathrm{F} 40$ candle exposed to $20 \mathrm{ppm} \mathrm{NaCl}$ and $15 \%$ steam at $870^{\circ} \mathrm{C}$ : c-ring compression test at $870^{\circ} \mathrm{C}$

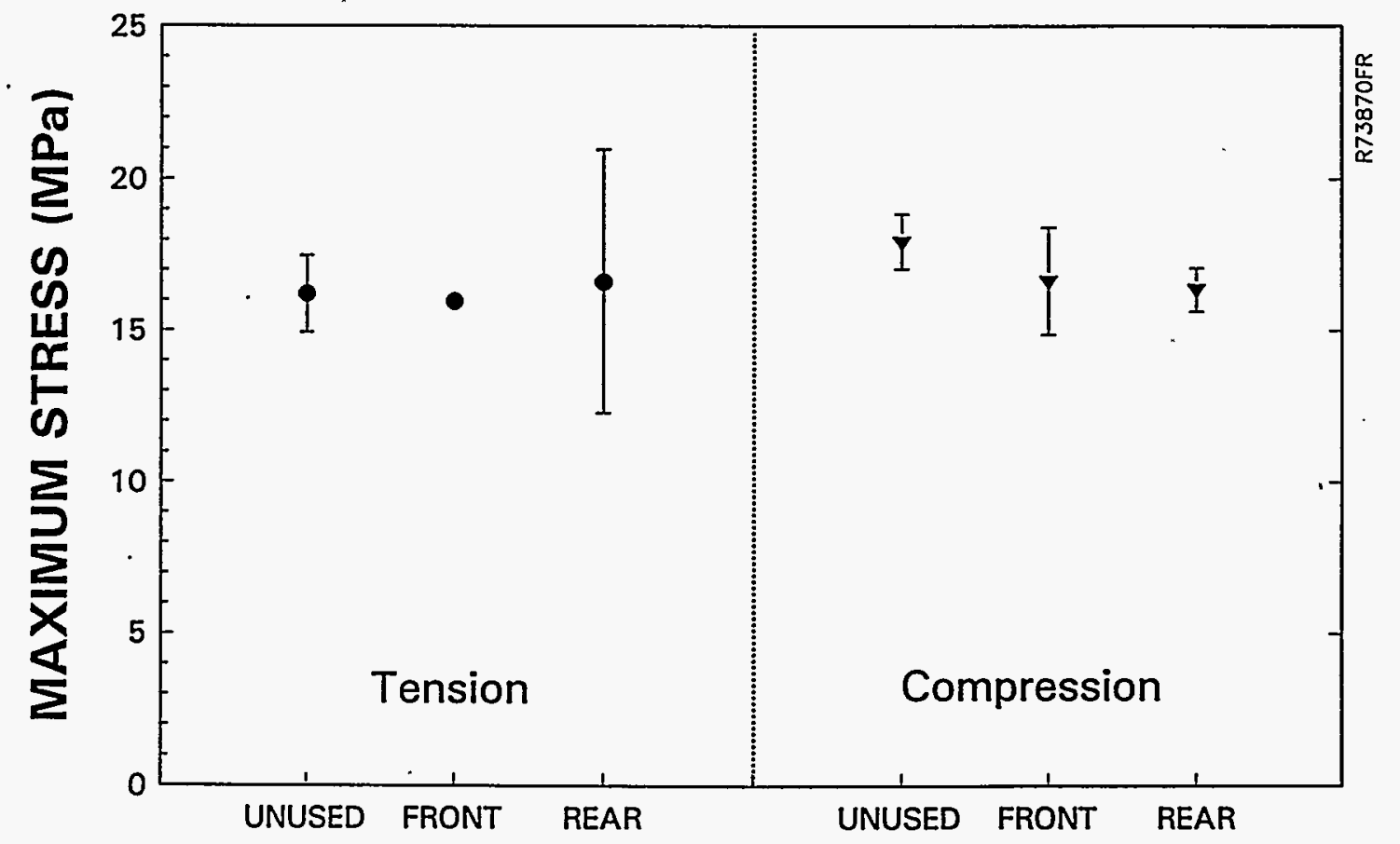

Figure 4-15. Refractron 70/3 with 442-T binder candle exposed to $20 \mathrm{ppm} \mathrm{NaCl}$ and $15 \%$ steam at $870^{\circ} \mathrm{C}$ for 100 hours (no pulse cleaning): c-ring tested at $870^{\circ} \mathrm{C}$ 

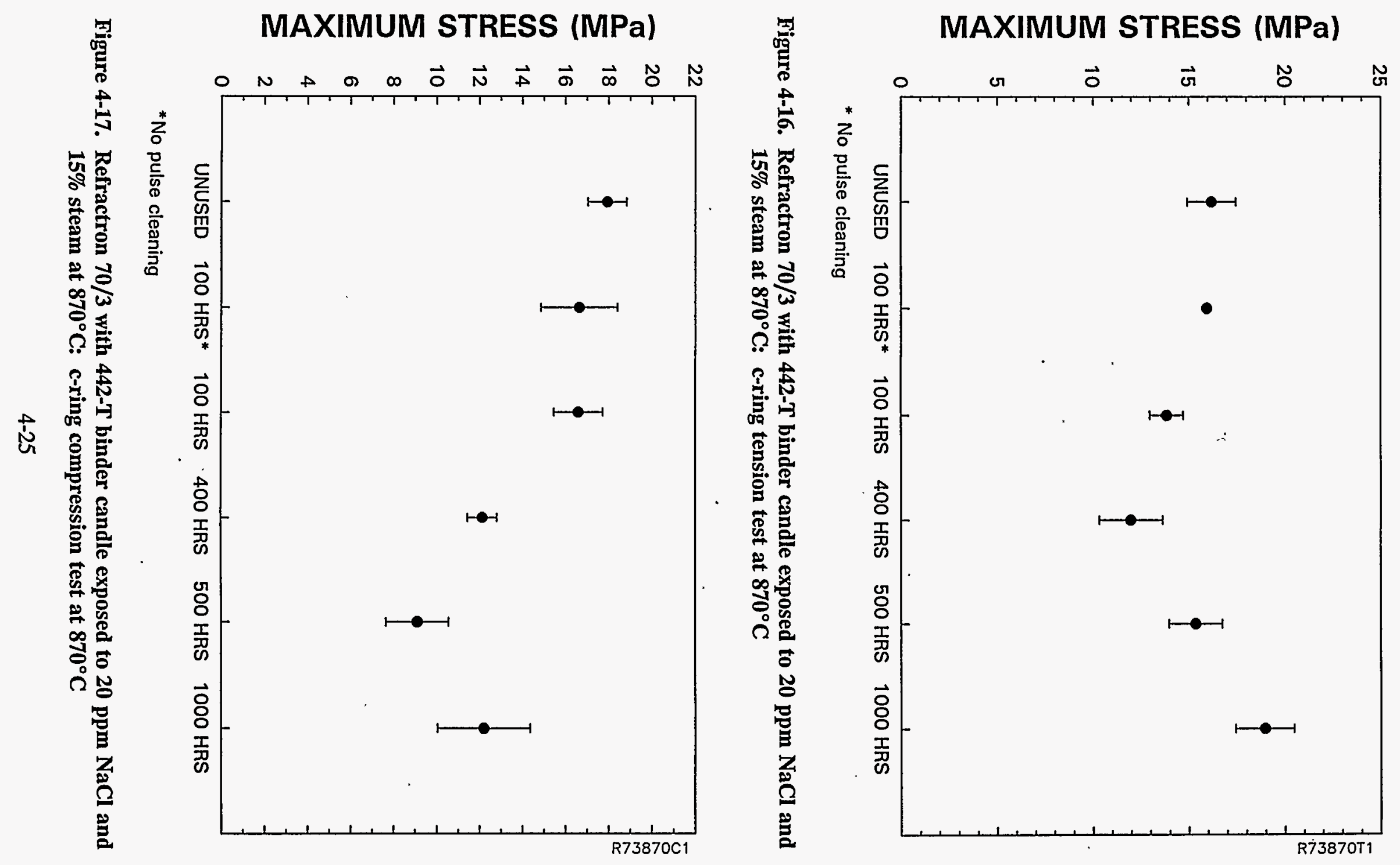

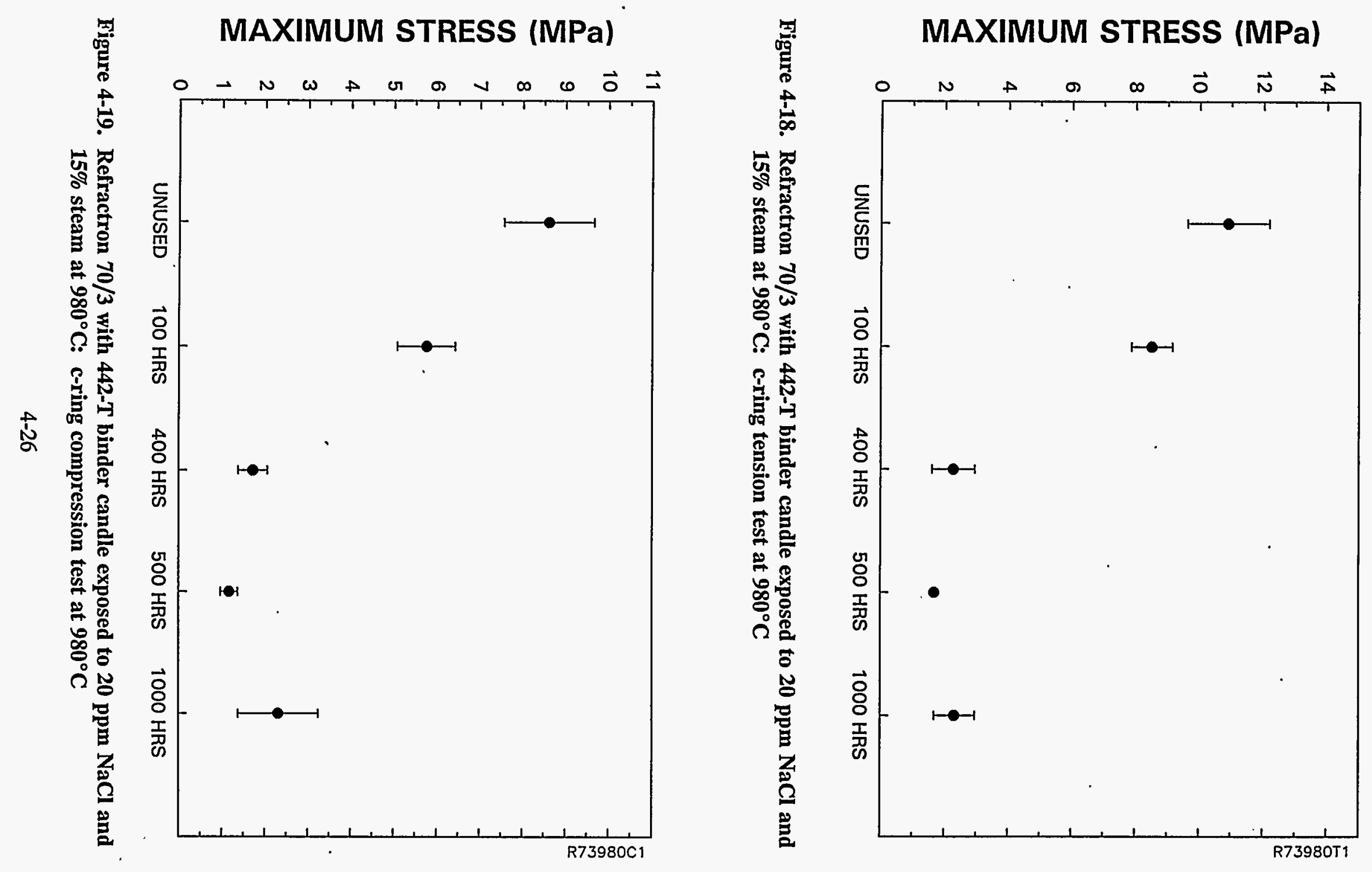
and a $40 \%$ increase in strength for the 500-hr specimen. Other than noting that the $1,000-\mathrm{hr}$ specimen is placed at the rear of the exposure vessel and the $500-\mathrm{hr}$ specimen is placed at the front of the vessel, there is no apparent explanation of the difference in strengths of the $500-\mathrm{hr}$ and the 1,000-hr candle specimens.

It can be seen in Figure 4-15 that there is no change in strengths for both surfaces (inner and outer) for the front and rear Refractron 70/3 with 442-T binder candles exposed for 100 hours (without any pulse cleaning) at $20 \mathrm{ppm} \mathrm{NaCl}, 15 \%$ steam, and $870^{\circ} \mathrm{C}$. There does not appear to be any difference in the placement of the candle specimens in the exposure vessel. However, it is possible that at longer exposure times and with the inclusion of pulse cleaning, there may be a difference between the front and the rear candle.

Figures 4-16 and 4-17 show that there is essentially no difference in strength relative to unused for the Refractron $70 / 3$ with $442-\mathrm{T}$ binder 100-hr exposure specimens (both with and without pulse cleaning) at $20 \mathrm{ppm} \mathrm{NaCl}, 15 \%$ steam, and $870^{\circ} \mathrm{C}$ tested in c-ring compression. In c-ring tension, only the unpulsed 100-hr specimen had no change in strength (as mentioned above and in Figure 4-15). there is about a $15 \%$ drop in strength for the 100-hr pulsed specimen when tested in tension. The $400-\mathrm{hr}$ specimen had a 25 to $30 \%$ decrease in strength for the inner and outer surfaces (tested in tension and compression). The 500- and 1,000-hr specimens showed no significant change in the tension test, but did show a 30 to $50 \%$ drop in strength in the compression test.

There is a 20 to $35 \%$ loss in strength on the inner and outer surfaces for the Refractron $70 / 3$ with $442-\mathrm{T}$ binder candle exposed for 100 hours at $20 \mathrm{ppm} \mathrm{NaCl}, 15 \%$ steam, and $980^{\circ} \mathrm{C}$ (refer to Figures 4-18 and 4-19). The inner and outer surfaces showed a tremendous 75 to $85 \%$ loss in strength for the 400-, 500-, and 1,000-hr exposure specimens. The rate of loss in strength for the outer surface is similar to the inner surface. It appears to be consistent in terms of major strength loss after 400 hours of exposure. 


\subsubsection{C-Ring Testing: KRW Candle Strength}

In the report "Analysis of Candle Filters from the KRW Gasifier" (refer to Appendix F), 4-point flexure (bend) tests were used to ascertain the strength of the candle. At the time, Acurex Environmental had not yet finished development of the C-Ring Testing system. The report indicated that there had been no obvious strength degradation in material strength of the used candles from unused. After the c-ring testing system was developed, the KRW candles were tested to verify whether the 4-point flexure tests were appropriate for testing ceramic candle strength. Table 4-13 and Figures 4-20 and 4-21 displays the c-ring test results. Note that the high temperature $\left(650^{\circ} \mathrm{C}\right)$ c-ring compression tests were based upon a c-ring sample population of less than 5 per candle due to the amount of material available.

It can be seen in Figure 4-20 (comparing only the unused candle with the average of the used candles) that there is about 15 to $25 \%$ drop in strength in the candle's inner surface that the 4-point flexure specimens (refer to Appendix F) could not detect. There is an obvious strength degradation that would be attributed to the pulse cleaning because the outer surface strength measurements does not show any strength loss (the high strength value for the unused candle at $650^{\circ} \mathrm{C}$ in Figure 4-21 is questionable due to the lack of enough material for $5 \mathrm{c}$-ring specimens per candle per test condition). The 4-point flexure tests confirm that the body of the candle between the inner and outer surfaces did not get weaker. Therefore the candles exposed to the operating conditions at KRW had the strength degradation confined to the inner surface where thermal shock from pulse cleaning would have the most effect.

\subsection{SEM/EDX ANALYSIS}

In the thermal exposure tests (see section 3.3.1), Tests A-D were aborted before the full 1,000 hours of testing because it was determined that the $\mathrm{NaCl}$ levels were higher than the $20 \mathrm{ppm}$ $\mathrm{NaCl}$ target. The Schumacher Diaschumalith F40 candle was tested at $870^{\circ} \mathrm{C}$ for the full 1,000 hours with correct $\mathrm{NaCl}$ levels. The Refractron $70 / 3$ with $442-\mathrm{T}$ binder candle was tested at $870^{\circ} \mathrm{C}$ and $980^{\circ} \mathrm{C}$ for the full 1,000 hours also with correct $\mathrm{NaCl}$ levels. The candles tested at $980^{\circ} \mathrm{C}$ were 
Table 4-13. C-ring tests on KRW candles

\begin{tabular}{|c|c|c|c|c|c|c|}
\hline & \multirow{2}{*}{$\begin{array}{l}\text { C-Ring } \\
\text { Width } \\
\text { (inch) }\end{array}$} & \multirow[b]{2}{*}{$\begin{array}{c}\text { Temperature } \\
\left({ }^{\circ} \mathrm{C}\right)\end{array}$} & \multicolumn{2}{|c|}{ Tension } & \multicolumn{2}{|c|}{ Compression } \\
\hline & & & $\begin{array}{l}\text { Stress } \\
\text { (Mpa) }\end{array}$ & $\begin{array}{c}\text { 土Std } \\
\text { Dev }\end{array}$ & $\begin{array}{l}\text { Stress } \\
\text { (Mpa) }\end{array}$ & $\begin{array}{c} \pm \text { Std } \\
\text { Dev }\end{array}$ \\
\hline Unused (7068) & 0.75 & Room & 24.29 & 1.00 & 21.16 & 0.96 \\
\hline Unused (7068) & 0.75 & $650^{\circ} \mathrm{C}$ & 25.02 & 1.29 & $25.38^{\mathrm{a}}$ & 1.84 \\
\hline Used (7052) & 0.75 & Room & 18.21 & 1.38 & 17.58 & 2.18 \\
\hline Used (7052) & 0.75 & $650^{\circ} \mathrm{C}$ & 19.60 & 0.99 & $18.89^{\mathrm{a}}$ & 1.48 \\
\hline Used (7067) & 0.75 & Room & 18.10 & 0.83 & 20.81 & 1.08 \\
\hline Used (7067) & 0.75 & $650^{\circ} \mathrm{C}$ & 21.27 & 0.49 & $21.36^{\mathrm{a}}$ & 0.79 \\
\hline Used (Average) & 0.75 & Room & 18.16 & 1.11 & 19.20 & 1.63 \\
\hline Used (Average) & 0.75 & $650^{\circ} \mathrm{C}$ & 20.44 & 0.74 & $20.13^{a}$ & 1.14 \\
\hline
\end{tabular}

${ }^{\text {aThe }}$ c-ring compression values at $650^{\circ} \mathrm{C}$ were based upon less than 5 specimens per candle

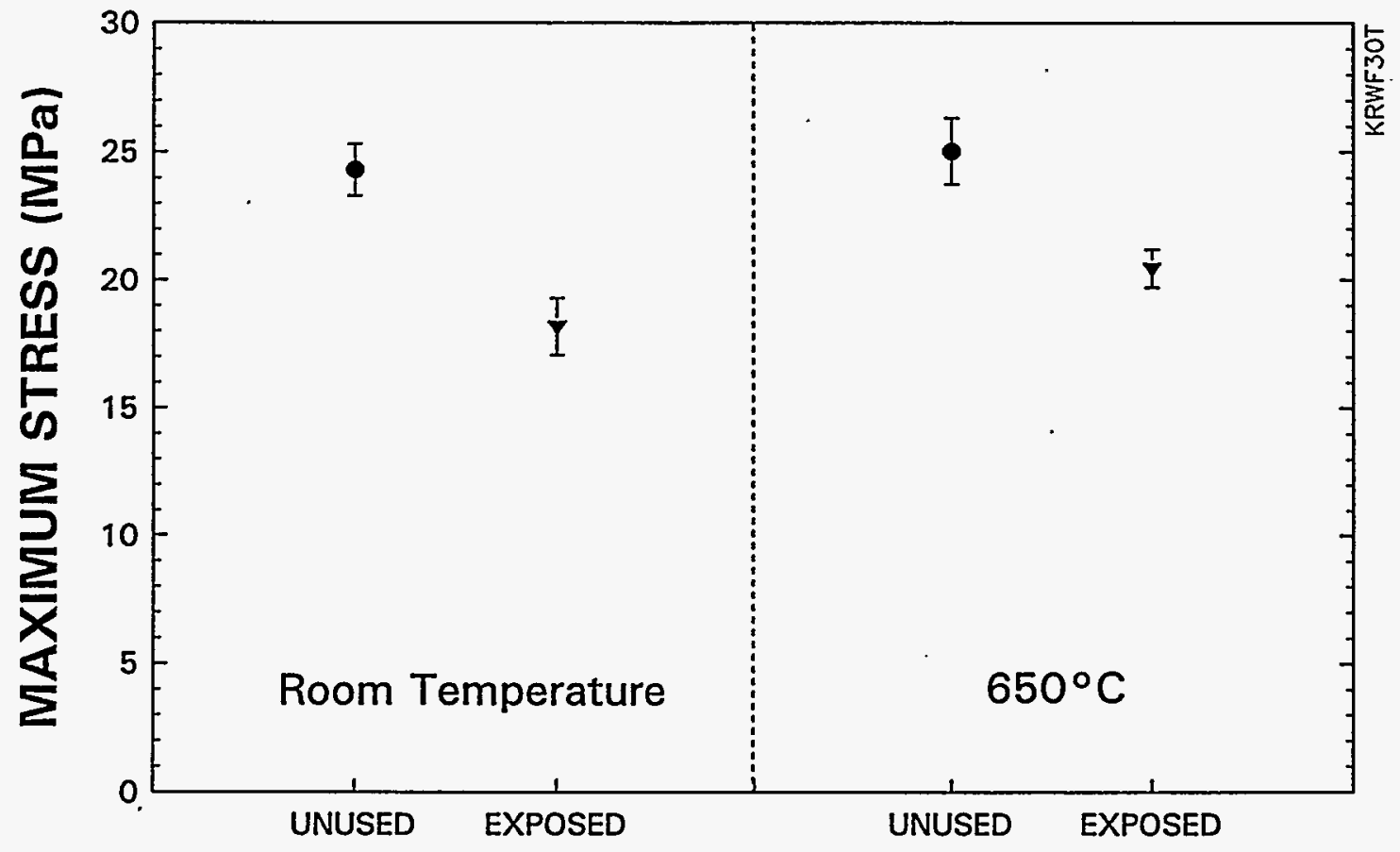

Figure 4-20. KRW candles: c-ring tension tests 


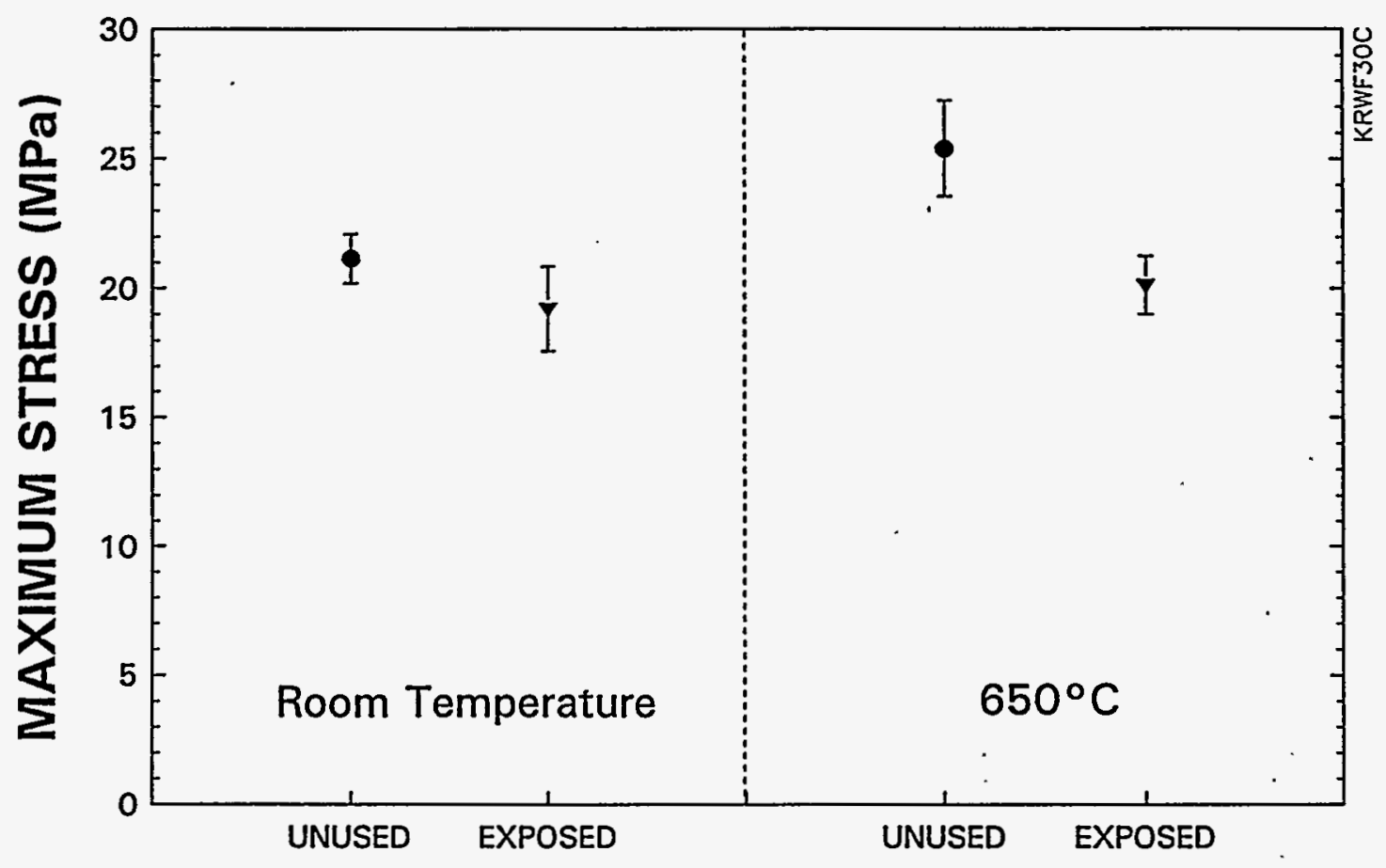

Figure 4-21. KRW candles: c-ring compression tests

deformed and showed evidence of melting and flowing. The final condition of the candles was unacceptable for use in that environment $\left(20 \mathrm{ppm} \mathrm{NaCl} / 15 \% \mathrm{H}_{2} \mathrm{O} / 980^{\circ} \mathrm{C}\right)$.

The SEM/EDX analysis of an unused Schumacher candle showed a fibrous outer layer (see Figure 4-22) that consists of about $90 \% \mathrm{Si}$ and $10 \% \mathrm{Al}$ (the EDX detector used could not determine elements of atomic weights less than 23 (sodium)). Figure 4-23 shows the outer layer of the candle from Test $\mathrm{H}\left(20 \mathrm{ppm} \mathrm{NaCl} / 15 \% \mathrm{H}_{2} \mathrm{O} / 870^{\circ} \mathrm{C} / 1,000\right.$ hours). The SEM micrograph shows an outer layer that had melted and flowed. The fibers that are easily recognized in Figure 4-22 are no longer evident in Figure 4-23. The Test $\mathrm{H}$ candle outer surface consisted of about $34 \% \mathrm{Si}, 4 \% \mathrm{Al}, 42 \% \mathrm{Fe}$, and $13 \% \mathrm{Cr}$ (the balance are of other elements). The presence of $\mathrm{Fe}$ and $\mathrm{Cr}$ suggests that the high temperature air, steam, and alkali chemically attacked the pre-vessel piping. The corrosion byproducts were then deposited onto the candle. The inner candle surface revealed $46 \% \mathrm{Si}, 6 \%$ $\mathrm{Al}, 24 \% \mathrm{Fe}, 12 \% \mathrm{Cr}$, and $0.5 \% \mathrm{Na}$. This shows that the vessel corrosion byproducts reached all the 


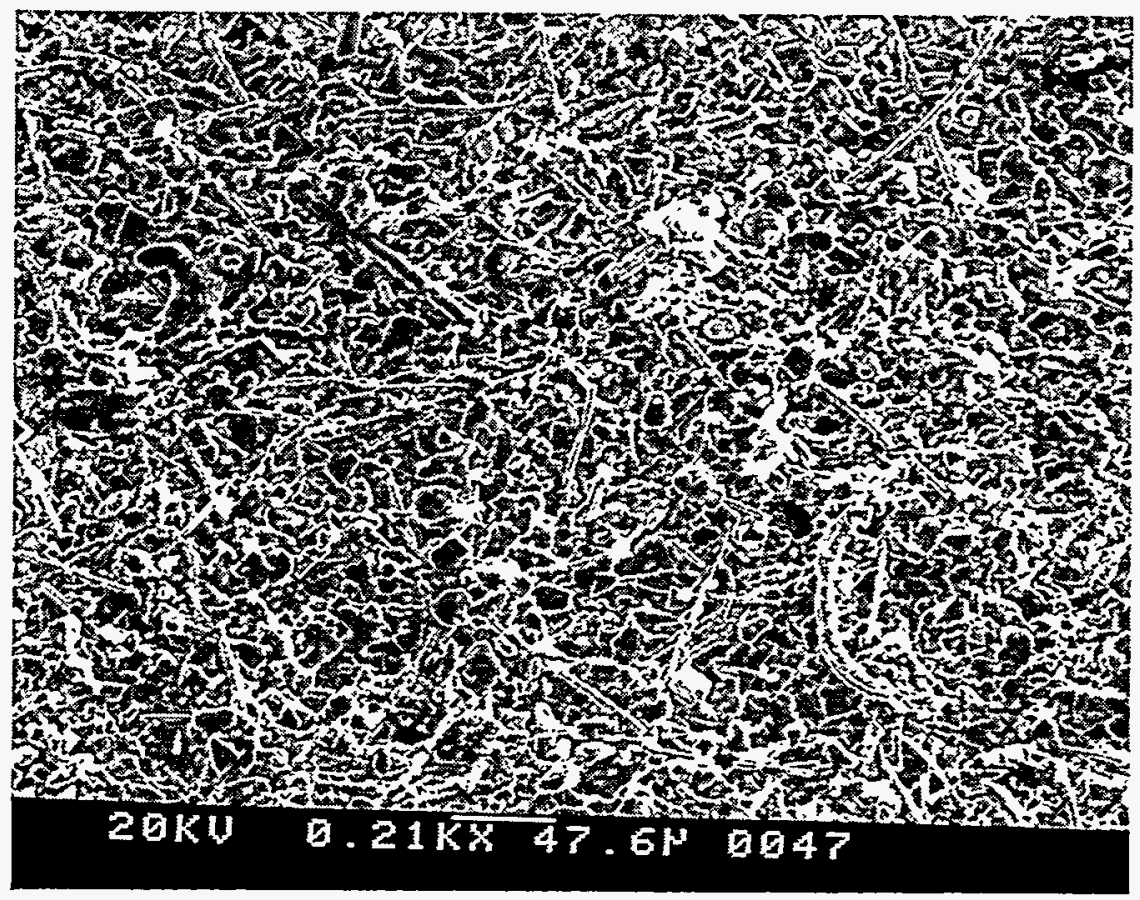

Figure 4-22. Micrograph of Schumacher F40/Unused: Outer surface (210X)

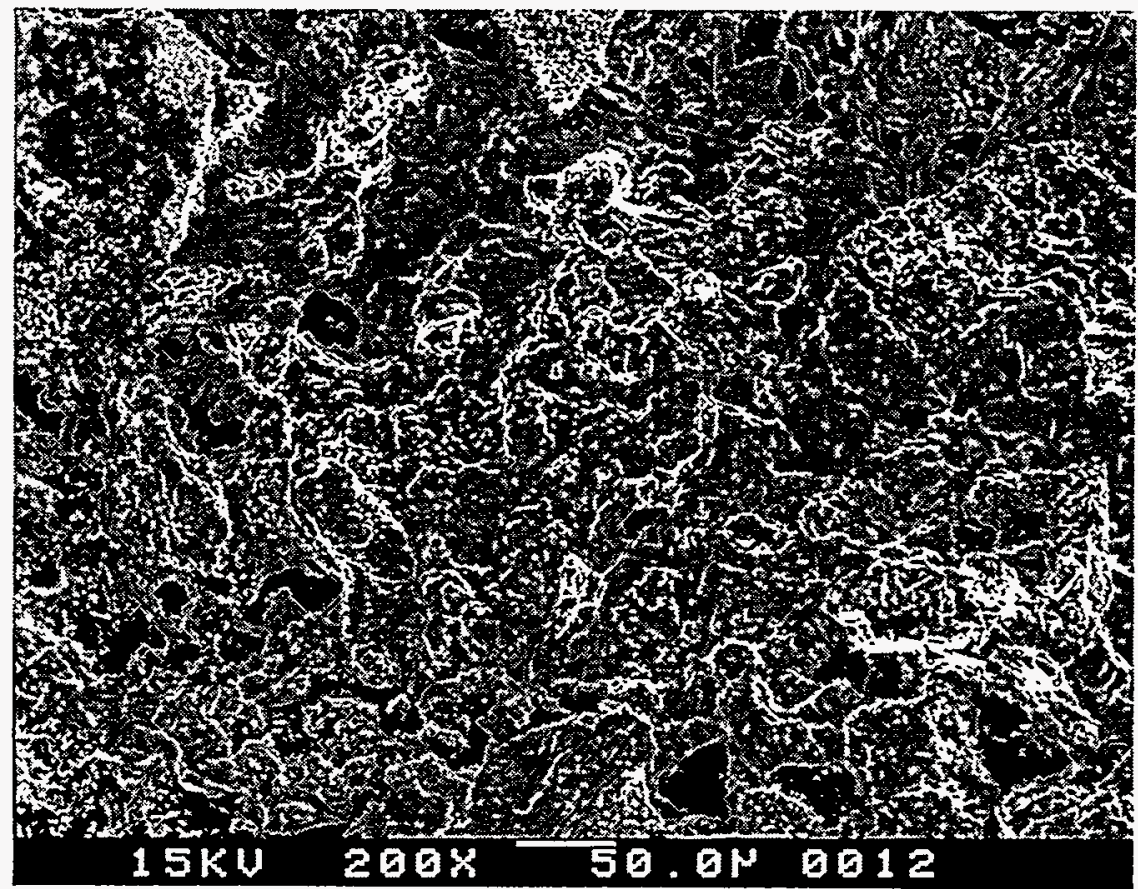

Figure 4-23. Micrograph of Schumacher F40/20 ppm NaCl/15\% $\mathrm{H}_{2} \mathrm{O} / 870^{\circ} \mathrm{C} / 1,000$ hours: Outer surface $(200 \mathrm{X})$ 
way to the interior of the candle. It also appears that the outer surface experienced blocking of pore openings by the melting and flowing of the surface. The shape of the candle had been retained and was not deformed as were the candles tested at $980^{\circ} \mathrm{C}$.

Figure 4-24 shows the cross-sectional view of the unused Schumacher candle (outer surface on right side of micrograph). Figure 4-25 is the cross-sectional view (outer surface on right side of micrograph) of the Schumacher candle from Test H. In comparing the two cross-sectional views, it can be seen that the SiC grains that make up the body of the Schumacher candle is still present.

Using SEM/EDX analysis, the outer surface of an unused Refractron 70/3 with 442-T binder candle (see Figure 4-26) contains about $91 \% \mathrm{Si}, 3 \% \mathrm{Al}$, and $3 \% \mathrm{Fe}$. The outer surface of the Refractron candle from Test $\mathrm{M}\left(20 \mathrm{ppm} \mathrm{NaCl} / 15 \% \mathrm{H}_{2} \mathrm{O} / 870^{\circ} \mathrm{C} / 1,000\right.$ hours $)$ is shown in Figure 4-27 and contains about $36 \% \mathrm{Si}, 4 \% \mathrm{Al}, 38 \% \mathrm{Fe}, 9 \% \mathrm{Cr}$, and $0.5 \% \mathrm{Na}$. It can be seen in Figure 4-27 that there had been some melting and flow of the outer surface, but it appears that the pore structure has not been as blinded/plugged as in the Schumacher candle at the same operating conditions. The shape of the small grains on the outer surface can still be distinguished.

Figure 4-28 shows the inner surface of an unused Refractron candle from Test $M$ which consists of about $70 \% \mathrm{Si}, 13 \% \mathrm{Al}, 3 \% \mathrm{Fe}$, and $0.8 \% \mathrm{Na}$. The inner surface of the Refractron candle in Test $\mathrm{M}$ (Figure $4-29$ ) is comprised of about $77 \% \mathrm{Si}, 6 \% \mathrm{Al}, 6 \% \mathrm{Fe}, 0.5 \% \mathrm{Cr}$, and $1.5 \% \mathrm{Na}$. It is evident that there is also binder melting and flowing on the interior of the candle like the exterior. At higher magnification of the inner surface of the Refractron candle (Figure 4-30), microcracks can be observed. This magnification of the inner surface is at the same magnification as the outer surface (200X). No microcracks can be seen on the outer surface (Figure 4-27) like in the inner surface (Figure 4-30).

From the EDX analysis, it appears that most of the corrosion byproducts from the metallic piping and vessel remained on the outer surface of the Refractron candles.

Examination of the exposed filters show that there had been some bond depletion and flowing of the candle material. The flowing of the binder (becoming viscous at high temperature) 


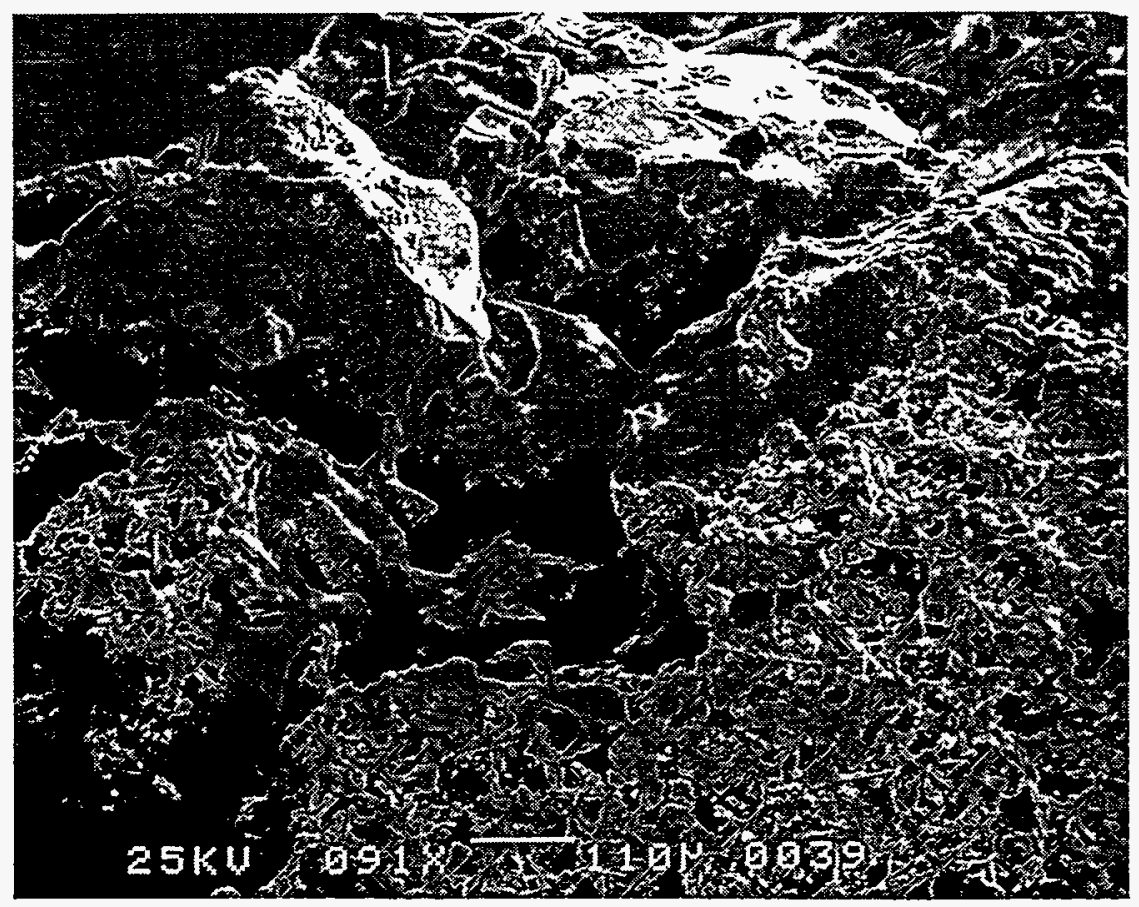

Figure 4-24. Micrograph of Schumacher F40/Unused: Cross-section (91X)

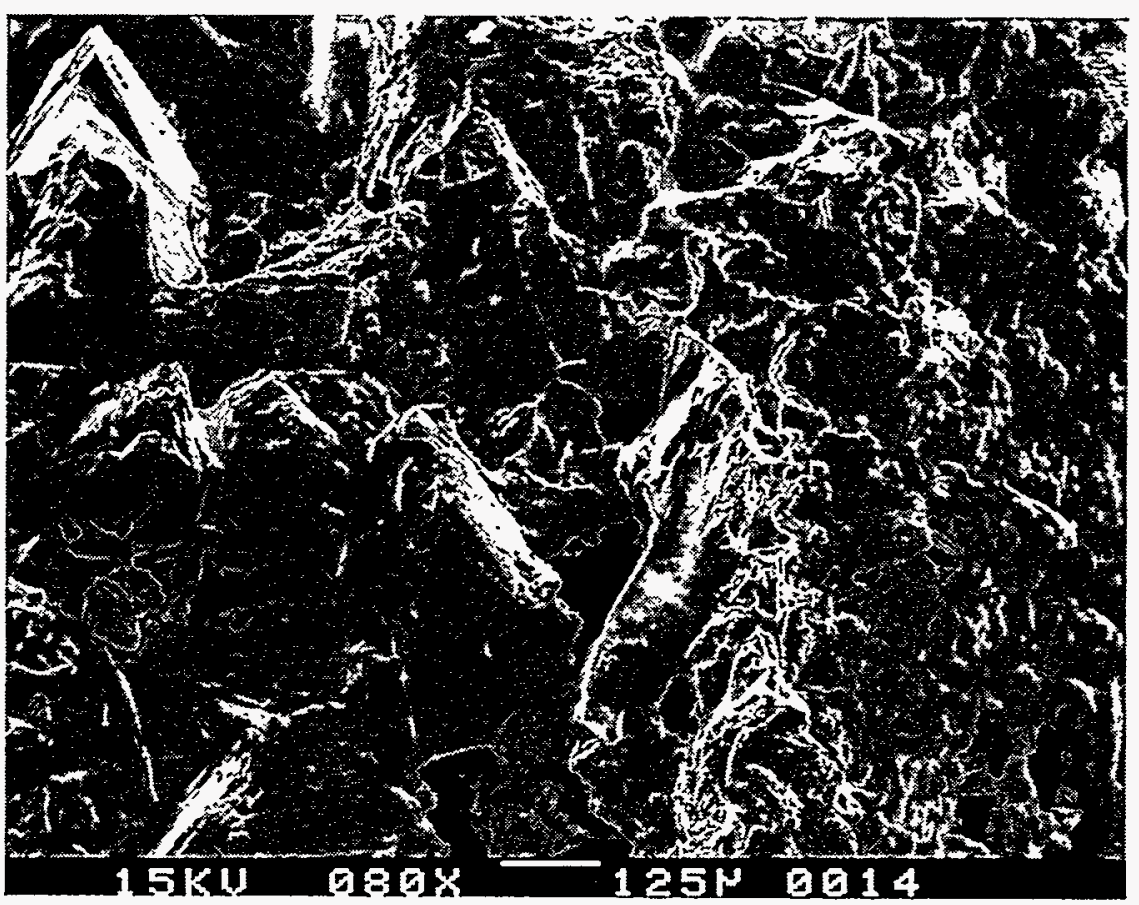

Figure 4-25. Micrograph of Schumacher F40/20 ppm NaCl/15\% $\mathrm{H}_{2} \mathrm{O} / 870^{\circ} \mathrm{C} / 1,000$ hours: Cross-section (80X) 


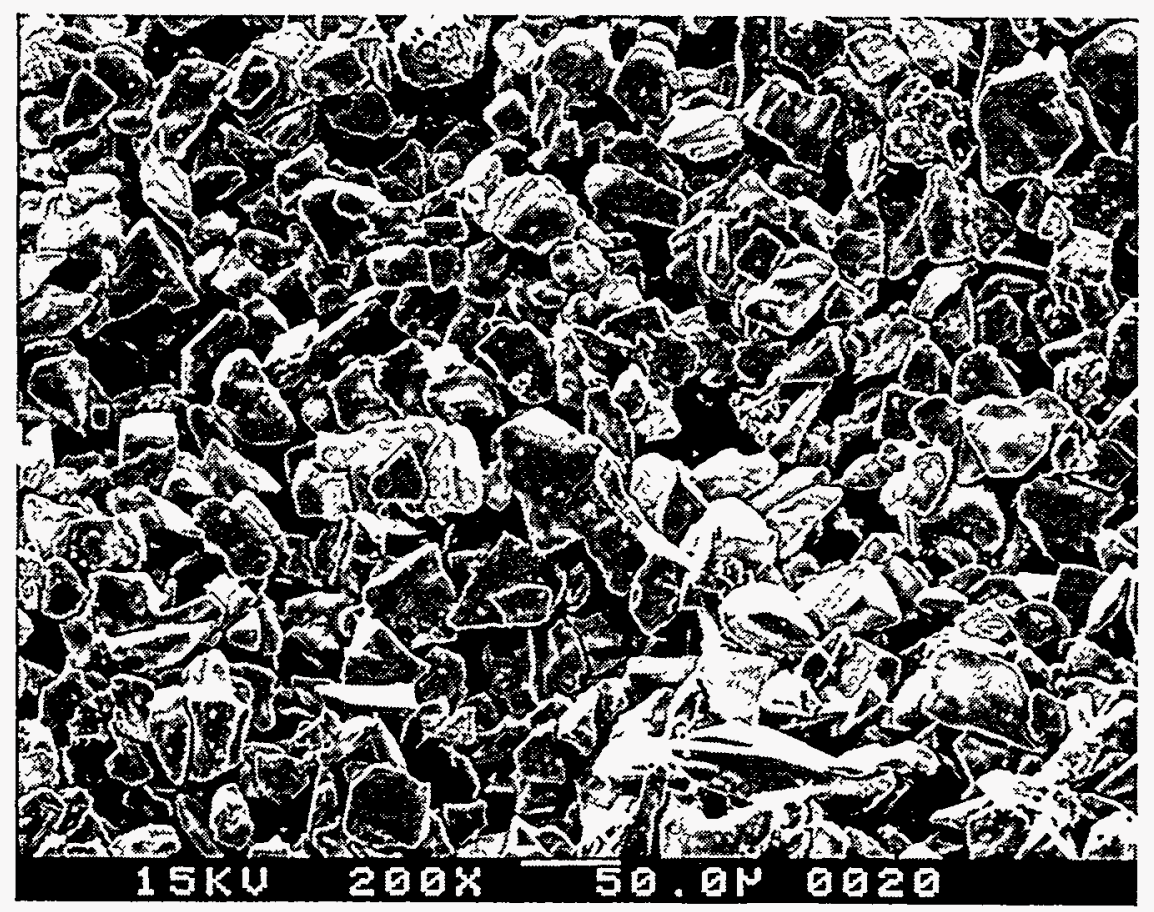

Figure 4-26. Micrograph of Refractron $70 / 3$ with $442-T$ /Unused: Outer surface $(200 \mathrm{X})$

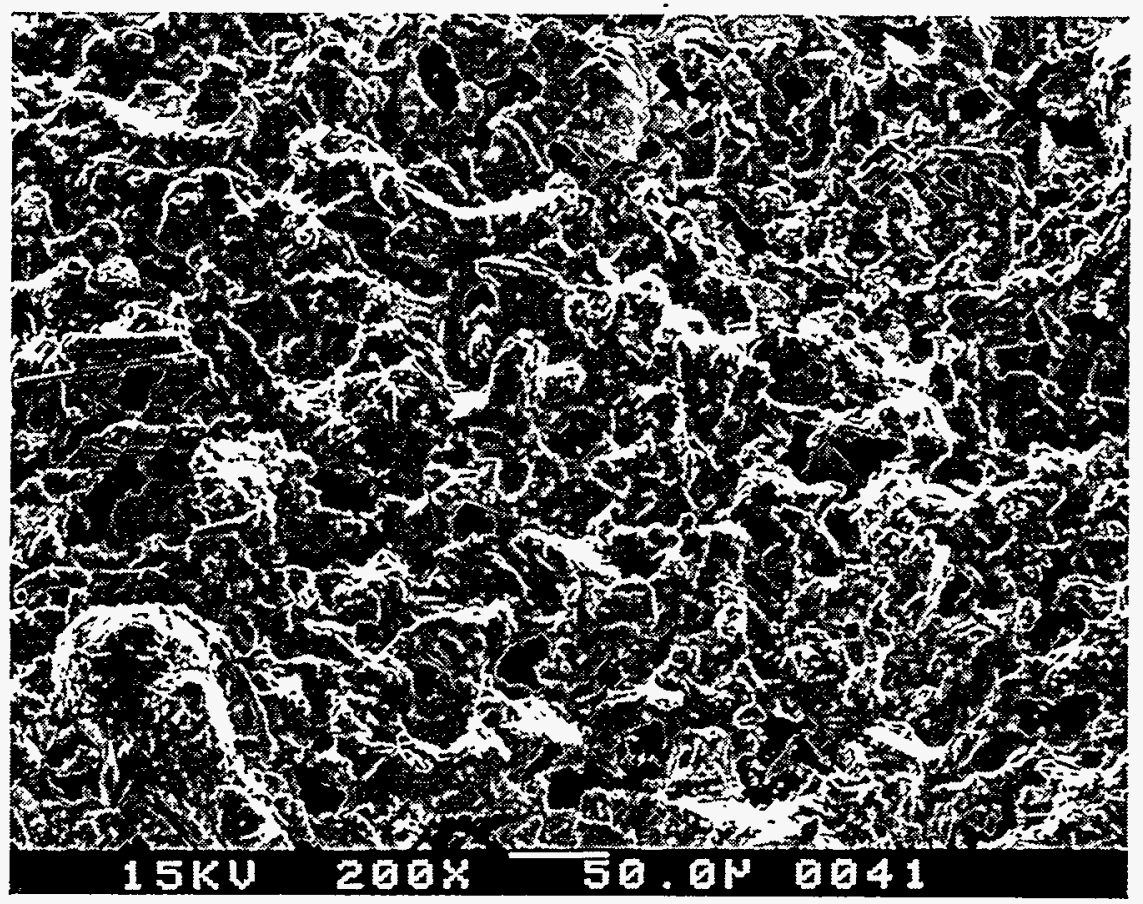

Figure 4-27. Micrograph of Refractron $70 / 3$ with $442-\mathrm{T} / 20 \mathrm{ppm}$ $\mathrm{NaCl} / 15 \% \mathrm{H}_{2} \mathrm{O} / 870^{\circ} \mathrm{C} / 1000$ hours: Outer surface (200X) 


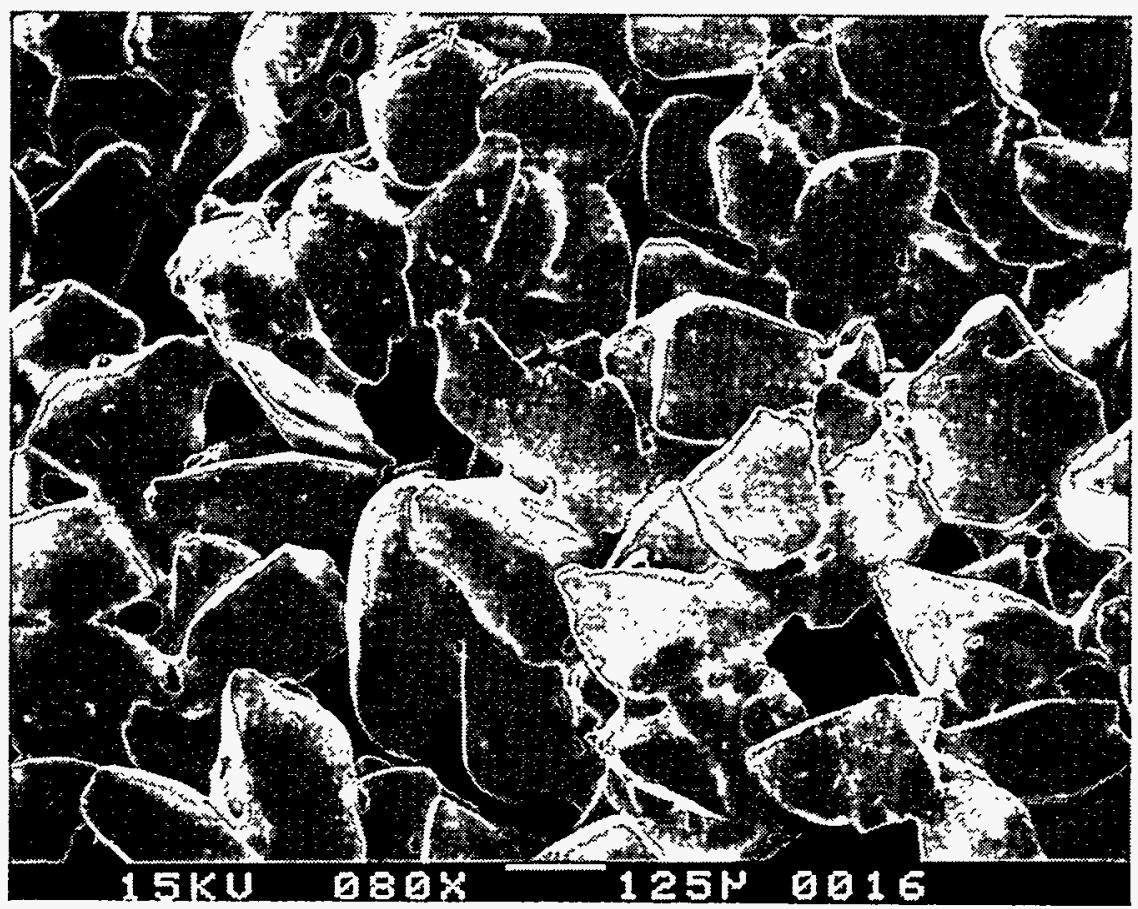

Figure 4-28. Micrograph of Refractron 70/3 with 442-T/Unused: Inner surface (80X)

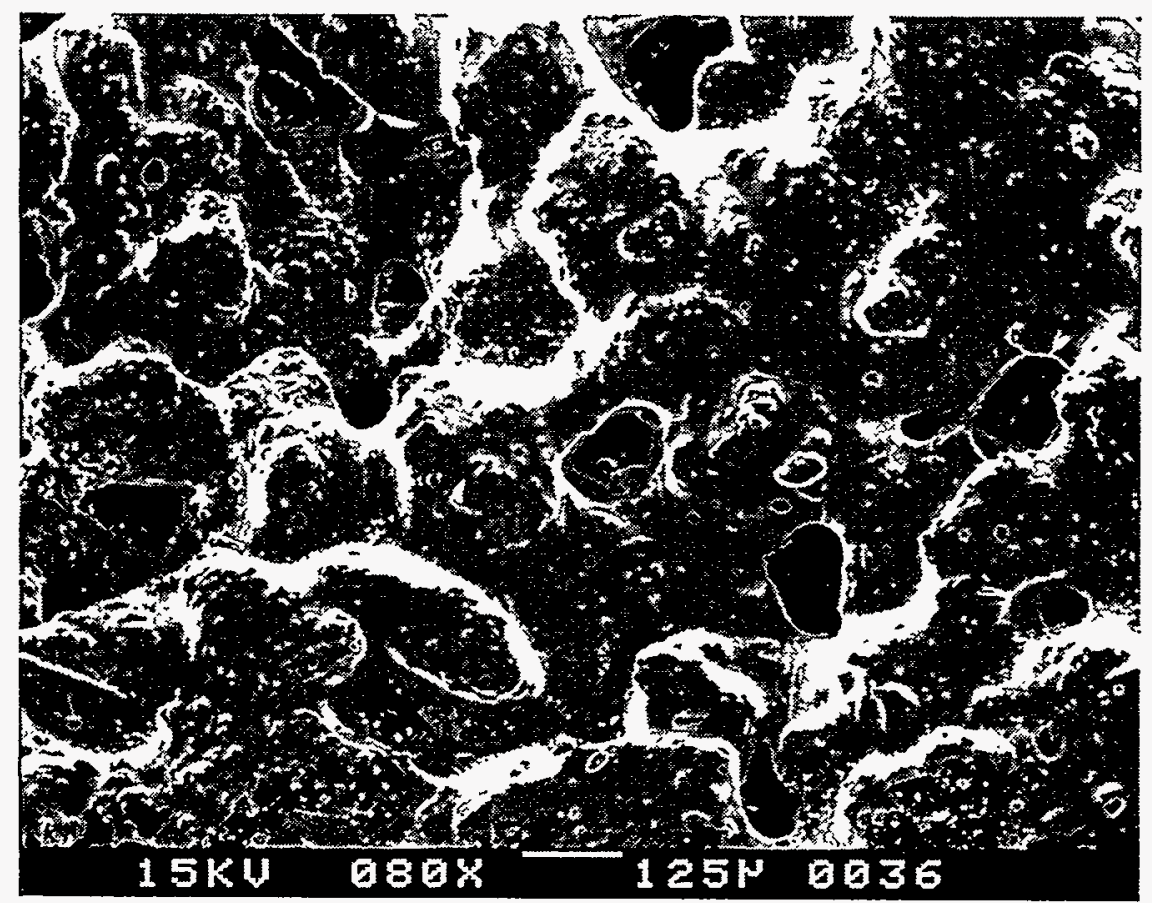

Figure 4-29. Micrograph of Refractron 70/3 with $442-\mathrm{T} / 20 \mathrm{ppm}$ $\mathrm{NaCl} / 15 \% \mathrm{H}_{2} \mathrm{O} / 870^{\circ} \mathrm{C} / 1,000$ hours: Inner surface (80X) 


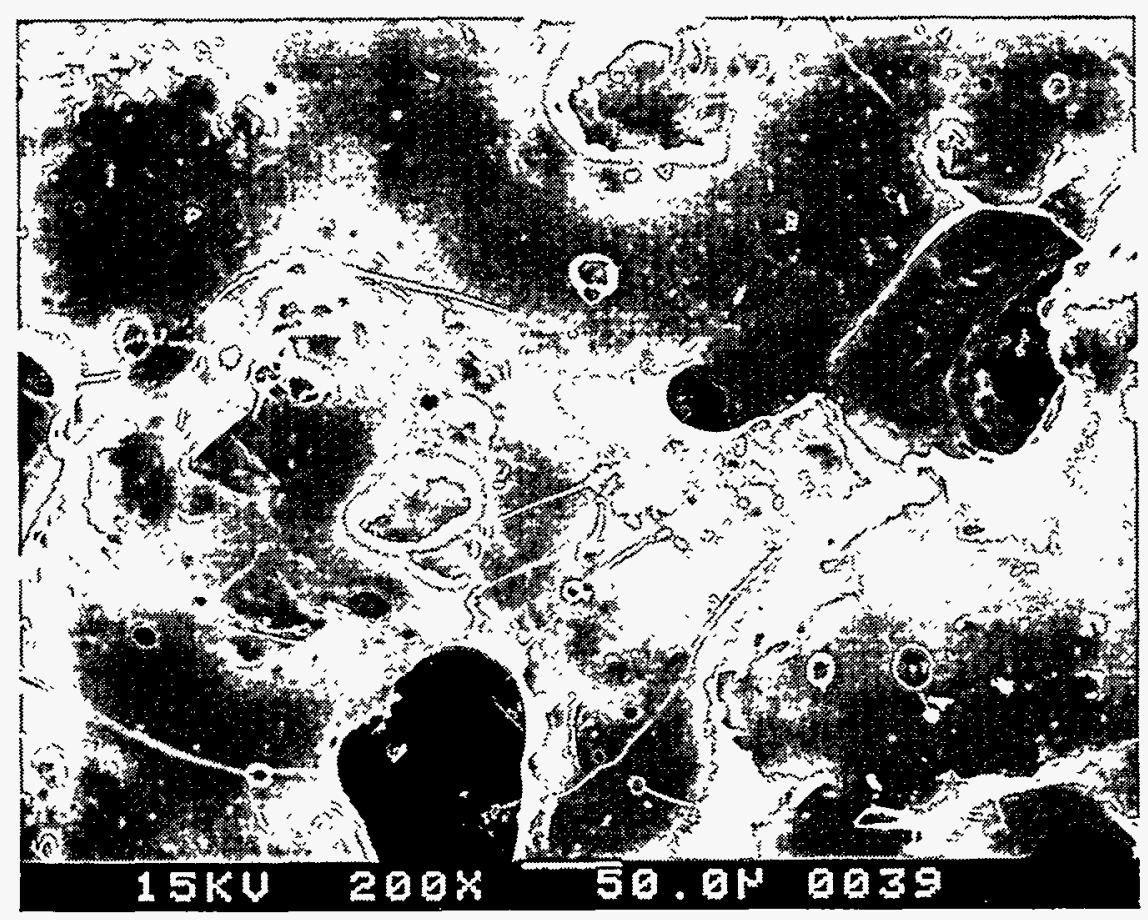

Figure 4-30. Micrograph of Refractron 70/3 with 442-T/20 ppm $\mathrm{NaCl} / 15 \% \mathrm{H}_{2} \mathrm{O} / 870^{\circ} \mathrm{C} / 1,000$ hours: Inner surface $(200 \mathrm{X})$

may have been due to gravity and aerodynamic drag of the hot gases flowing through the candle filters.

\subsection{XRD ANALYSIS}

XRD of the Schumacher and Refractron candle filters revealed silicon carbide (SiC) as the major constituent. This is expected because SiC grains constitute more than $90 \%$ of the total candle material. The lack of enough binder material to analyze makes the detection of changes of phases in the binder material difficult. A summary of XRD analyses performed are presented in Table 4-14 (the raw XRD data is presented in Appendix E). Instead of showing all of the individual compounds, the types of phases are presented instead. The following is a list of the individual compound numbers (as they appear in the Powder Diffraction File of the Joint Committee on Powder Diffraction Standards) for each phase listed in Table 4-14 (each dark square in Table 4-14 represents one or more of the listed compounds). 
Table 4-14. X-Ray diffraction summary

\begin{tabular}{|c|c|c|c|c|c|c|c|c|}
\hline \multirow[b]{2}{*}{ Test, } & \multirow{2}{*}{ Test Description/Condition } & \multirow{2}{*}{$\begin{array}{l}\text { Total } \\
\text { Pulses }\end{array}$} & \multicolumn{2}{|c|}{ Silicon Carbide } & \multicolumn{2}{|c|}{ Silicon Dioxide } & \multirow{2}{*}{$\begin{array}{c}\mathrm{NaAISi}_{3} \mathrm{O}_{8} \\
\text { Albite }\end{array}$} & \multirow{2}{*}{$\begin{array}{c}\mathrm{Al}_{2} \mathrm{O}_{3} \\
\text { Corundum }\end{array}$} \\
\hline & & & $\mathrm{SiC}$ & Moissanite & $\mathrm{SiO}_{2}$ & Cristobalite & & \\
\hline & Schumacher Diaschumalith F40 & & & & & & & \\
\hline $\mathrm{A}$ & $95 \mathrm{ppm} \mathrm{NaCl} / 20 \% \mathrm{H}_{2} \mathrm{O} / 870^{\circ} \mathrm{C} / 100 \mathrm{hrs}$ & 0 & & & & & & ?. \\
\hline $\mathrm{B}$ & $65 \mathrm{ppm} \mathrm{NaCl} / 20 \% \mathrm{H}_{2} \mathrm{O} / 980^{\circ} \mathrm{C} / 100 \mathrm{hrs}$ & 200 & & & & & & \\
\hline $\mathrm{E}$ & $20 \mathrm{ppm} \mathrm{NaCl} / 15 \% \mathrm{H}_{2} \mathrm{O} / 870^{\circ} \mathrm{C} / 100 \mathrm{hrs}$ & 230 & $\mathrm{n} / \mathrm{a}$ & $\mathrm{n} / \mathrm{a}$ & $\mathrm{n} / \mathrm{a}$ & $\mathrm{n} / \mathrm{a}$ & $\mathrm{n} / \mathrm{a}$ & $\mathrm{n} / \mathrm{a}$ \\
\hline $\mathrm{F}$ & $20 \mathrm{ppm} \mathrm{NaCl} / 15 \% \mathrm{H}_{2} \mathrm{O} / 870^{\circ} \mathrm{C} / 400 \mathrm{hrs}$ & 920 & $\mathrm{n} / \mathrm{a}$ & $\mathrm{n} / \mathrm{a}$ & $\mathrm{n} / \mathrm{a}$ & $\mathrm{n} / \mathrm{a}$ & $\mathrm{n} / \mathrm{a}$ & $\mathrm{n} / \mathrm{a}$ \\
\hline G & $20 \mathrm{ppm} \mathrm{NaCl} / 15 \% \mathrm{H}_{2} \mathrm{O} / 870^{\circ} \mathrm{C} / 500 \mathrm{hrs}$ & 1,140 & & & & & & \\
\hline $\mathrm{H}$ & $20 \mathrm{ppm} \mathrm{NaCl} / 15 \% \mathrm{H}_{2} \mathrm{O} / 870^{\circ} \mathrm{C} / 1,000 \mathrm{hrs}$ & 2,290 & & & & & & \\
\hline $\mathrm{J}$ & $20 \mathrm{ppm} \mathrm{NaCl} / 15 \% \mathrm{H}_{2} \mathrm{O} / 870^{\circ} \mathrm{C} / 100 \mathrm{hrs}$ & 240 & $\mathrm{n} / \mathrm{a}$ & $\mathrm{n} / \mathrm{a}$ & $\mathrm{n} / \mathrm{a}$ & $\mathrm{n} / \mathrm{a}$ & $\mathrm{n} / \mathrm{a}$ & $\mathrm{n} / \mathrm{a}$ \\
\hline $\mathrm{K}$ & $20 \mathrm{ppm} \mathrm{NaCl} / 15 \% \mathrm{H}_{2} \mathrm{O} / 870^{\circ} \mathrm{C} / 400 \mathrm{hrs}$ & 980 & $\mathrm{n} / \mathrm{a}$ & $\mathrm{n} / \mathrm{a}$ & $\mathrm{n} / \mathrm{a}$ & $\mathrm{n} / \mathrm{a}$ & $\mathrm{n} / \mathrm{a}$ & $\mathrm{n} / \mathrm{a}$ \\
\hline $\mathrm{L}$ & $20 \mathrm{ppm} \mathrm{NaCl} / 15 \% \mathrm{H}_{2} \mathrm{O} / 870^{\circ} \mathrm{C} / 500 \mathrm{hrs}$ & 1,170 & ?. & $\sqrt{1}$ & & & & 8 \\
\hline $\mathrm{M}$ & $20 \mathrm{ppm} \mathrm{NaCl} / 15 \% \mathrm{H}_{2} \mathrm{O} / 870^{\circ} \mathrm{C} / 1,000 \mathrm{hrs}$ & 2,390 & & i. & & & & \\
\hline$N$ & $20 \mathrm{ppm} \mathrm{NaCl} / 15 \% \mathrm{H}_{2} \mathrm{O} / 980^{\circ} \mathrm{C} / 100 \mathrm{hrs}$ & 230 & $\mathrm{n} / \mathrm{a}$ & $\mathrm{n} / \mathrm{a}$ & $\mathrm{n} / \mathrm{a}$ & $\mathrm{n} / \mathrm{a}$ & $\mathrm{n} / \mathrm{a}$ & $\mathrm{n} / \mathrm{a}$ \\
\hline $\mathrm{O}$ & $20 \mathrm{ppm} \mathrm{NaCl} / 15 \% \mathrm{H}_{2} \mathrm{O} / 980^{\circ} \mathrm{C} / 400 \mathrm{hrs}$ & 840 & $\mathrm{n} / \mathrm{a}$ & $\mathrm{n} / \mathrm{a}$ & $\mathrm{n} / \mathrm{a}$ & $\mathrm{n} / \mathrm{a}$ & $\mathrm{n} / \mathrm{a}$ & $\mathrm{n} / \mathrm{a}$ \\
\hline $\mathrm{P}$ & $20 \mathrm{ppm} \mathrm{NaCl} / 15 \% \mathrm{H}_{2} \mathrm{O} / 980^{\circ} \mathrm{C} / 500 \mathrm{hrs}$ & 1,060 & $\mathrm{n} / \mathrm{a}$ & $\mathrm{n} / \mathrm{a}$ & $\mathrm{n} / \mathrm{a}$ & $\mathrm{n} / \mathrm{a}$ & $\mathrm{n} / \mathrm{a}$ & $\mathrm{n} / \mathrm{a}$ \\
\hline Q & $20 \mathrm{ppm} \mathrm{NaCl} / 15 \% \mathrm{H}_{2} \mathrm{O} / 980^{\circ} \mathrm{C} / 1,000 \mathrm{hrs}$ & 2,130 & ?. & 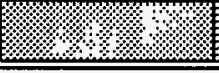 & & & & 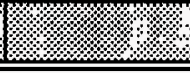 \\
\hline
\end{tabular}

$\mathrm{n} / \mathrm{a}=$ Data is not available because XRD analysis was not performed 
Silicon Carbide (SiC)

SiC: $\quad 1-119,4-0756,22-1273,22-1316,29-1127,29-1129$

Moissanite: $19-1138,29-1128,29-1130,29-1131$

Silicon Oxide $\left(\mathrm{SiO}_{2}\right)$

$\mathrm{SiO}_{2}: \quad 18-1169,27-0605,34-1382$

Cristobalite: $11-0695$

Sodium Aluminum Silicate $\left(\mathrm{NaAlSi}_{3} \mathrm{O}_{8}\right)$

Albite: $\quad 10-0393,20-0572$

Aluminum Oxide $\left(\mathrm{Al}_{2} \mathrm{O}_{3}\right)$

Corundum: $10-0173$

XRD analyses were not performed for the thermal exposure Tests $E, F, I, J, K, N, O$, and $P$.

Crystalline silica was detected in the used candles, but none was detected in the unused candles. This observation implies that the silicon was either tied up as another crystalline compound (such as $\mathrm{SiC}$ ) or as a noncrystalline compound (such as amorphous silica) before exposure. After exposure, the amorphous silica may have devitrified or silicon compounds (such as $\mathrm{SiC}$ ) may have reacted with oxygen to produce crystalline silica. Cristobalite was detected only in the used Schumacher candles exposed to $980^{\circ} \mathrm{C}(65 \mathrm{ppm} \mathrm{NaCl})$ or $95 \mathrm{ppm} \mathrm{NaCl}\left(870^{\circ} \mathrm{C}\right)$. The used Schumacher candles exposed to $20 \mathrm{ppm} \mathrm{NaCl}\left(870^{\circ} \mathrm{C}\right)$ did not show the presence of cristobalite. The presence of cristobalite is undesirable because of the difference in volume expansion (thermal expansion) of cristobalite compared to the volume expansion of the common form of silica (quartz). Cristobalite, the high-temperature polymorphic form of silica, has a density of about $2.32 \mathrm{~g} / \mathrm{cm}^{3}$, where as quartz has a density of $2.65 \mathrm{~g} / \mathrm{cm}^{3} .13$ This difference in density corresponds to differences in volume changes, which can lead to the cracking. The transformation temperature for cristobalite is $1,470^{\circ} \mathrm{C}$. Since the thermal exposure tests never exceeded $1,000^{\circ} \mathrm{C}$, then the presence of other elements (such as the $\mathrm{Na}$ modifier) has reduced the transition temperature to less than $1,000^{\circ} \mathrm{C}$. This could mean that each time a "cold" air pulse cleaning 
occurs, the drop in temperature could cause the formation of microcracks (due to the volume mismatch) which degrades the strength of the candles.

The cristobalite phase was only noticed in the Schumacher candles tested at $980^{\circ} \mathrm{C}$ and/or $>15 \%$ steam and/or $>20 \mathrm{ppm} \mathrm{NaCl}$. No cristobalite was detected for the Schumacher candles tested at $870^{\circ} \mathrm{C}$ nor any of the Refractron candles tested (both at $870^{\circ} \mathrm{C}$ and $980^{\circ} \mathrm{C}$ ).

Albite $\left(\mathrm{NaAlSi}_{3} \mathrm{O}_{8}\right)$ was detected only in the exposed Refractron candles, hence the formation of albite is as a result from the exposure testing at both $870^{\circ} \mathrm{C}$ and $980^{\circ} \mathrm{C}$. The same type of argument for the formation of microcracking can be applied to albite as it did for cristobalite. However, the exact effect of albite on the candle properties are unknown. It is also a possibility that the formation of albite (which incorporates the $\mathrm{Na}$ modifier) would decrease the viscosity of the candle that would result in crack blunting.

Corundum $\left(\mathrm{Al}_{2} \mathrm{O}_{3}\right)$ was detected in all candles tested except for the unused Schumacher candle. It is assumed that the alumina in the unused Schumacher candle is in the form of amorphous alumina.

\subsection{FIBROSIC TEST RESULTS}

Industrial Filter and Pump (IFP) has developed a fibrous filter that is different from the rigid candles (typically $\mathrm{SiC}$ grains held together by an alumino-silicate binder) tested above. The filter is a vacuum-formed body which is post-treated to strengthen the high stress areas and modify the surface pore size. In late 1991 and early 1992, Acurex Environmental performed durability testing (funded by the Electric Power Research Institute) of the Fibrosic candle under development by IFP. In operation, the Fibrosic candles performed well (having high collection efficiency with low pressure drop), but the candle durability was suspect because the candles catastrophically failed during testing. These candles were assembled by gluing a flange onto the vacuum-formed body. The tests showed the glued joint to be the weak area. The burst tests of these filters showed the used candles to have a candle burst pressure of approximately 8 psi whereas the unused candles 
burst at approximately $16 \mathrm{psi}$. These measurements indicated there had been significant strength loss from use.

\subsubsection{Fibrosic Candle Test Results}

Since the original tests, IFP has further developed the Fibrosics filter. A final part of the project assessed the durability of the new Fibrosic filter to accelerated pulse cleaning at high temperature and to actual filtration operating conditions. The Fibrosics candle test conditions were:

- Temperature: $1,600^{\circ} \mathrm{F}\left(870^{\circ} \mathrm{C}\right)$

- Pressure: Atmospheric

- Dust: $\quad$ PFBC flyash $\left(4.7 \mu \mathrm{m} \mathrm{D}_{50}\right)$

- Dust load: $\quad 4,000 \mathrm{ppm}_{\mathrm{w}}$

- Pulse pressure: $60 \mathrm{psig}$

- Pulse duration: 0.5 seconds

- Face velocity: $8 \mathrm{ft} / \mathrm{min}$

Table 4-15 summarizes the test results performed on the Fibrosic candles.

Table 4-15. Fibrosics candle test summary

\begin{tabular}{|l|c|c|c|}
\hline & Unused & $\begin{array}{c}\text { Accelerated } \\
\text { Pulse Cleaning }\end{array}$ & $\begin{array}{c}\text { Operational } \\
\text { Filtration }\end{array}$ \\
\hline Pulse Frequency (sec) & & $30-50$ & \\
$\Delta$ P Set Point (inches $\mathrm{H}_{2} \mathrm{O}$ ) & & & 15 \\
Pulse Duration (sec) & & 0.5 & 0.5 \\
Total Number of Pulses & & 15,000 & 20 \\
Total Time (hours) & & 200 & 100 \\
Collection Efficiency (\%) & & $99.992 \%(0$ pulses) & 99.995 (10 hours) \\
& & $99.990 \%(5 \mathrm{k}$ pulses) & 99.995 (24 hours) \\
& & $99.992 \%(10 \mathrm{k}$ pulses) & 99.998 (53 hours) \\
& & & 99.998 (79 hours) \\
Burst Pressure (psig) & 20 & 16 & 99.999 (100 hours) \\
\hline
\end{tabular}


Upon disassembly of the candle from the accelerated pulse cleaning test, a crack was discovered about 4 inches from the bottom of the candle flange. The crack was perpendicular to the axial length of the candle and extended about 3.5 inches along the candle surface. The crack depth (measured about mid-point along the crack) was estimated to be about $1 / 8$ of an inch. The crack had not propagated to the interior wall. The collection efficiency results confirm this observation.

The cylindrical burst strength tests performed on the accelerated pulsed cleaned candle resulted in the failure of the candle at a location other than at the crack site. This is contrary to the expectation that the site of candle failure would be at the weakest part of the candle which is presumed to be the crack.

Figure 4-31 shows the Fibrosic candle permeability at $870^{\circ} \mathrm{C}$ during the accelerated pulse cleaning tests. The results show that initially, the permeability dropped (pressure drop across filter increased) at the 5,000 and 10,000 pulse mark, and then increased at the 15,000 (concluding) mark. The initial drop in permeability could be attributed to the fact that filter collection efficiencies were also being performed on the same candle. The flyash used during collection efficiency tests remained on the surface of the candle, affecting the permeability.

Figure 4-32 shows the Fibrosic candle permeability at $870^{\circ} \mathrm{C}$ during the 100 hour operational filtration testing. This candle test also shows the same initial drop in permeability followed by an increase after the 50 hour mark.

There was only one candle available for each test.

\subsubsection{Fibrosic Tubesheet Test Results}

IFP has also been developing a fibrous ceramic tubesheet and candle hold-down system. This approach has appeal by reducing the amount of metal subjected to high temperature gas. The tubesheet/hold-down assembly has not been subjected to sufficient testing. There is no long term testing data of the structural integrity of the Fibrosic tubesheet at high temperature. Simulation of the "worst" case structural conditions that the tubesheet can encounter was done (see Section 3 


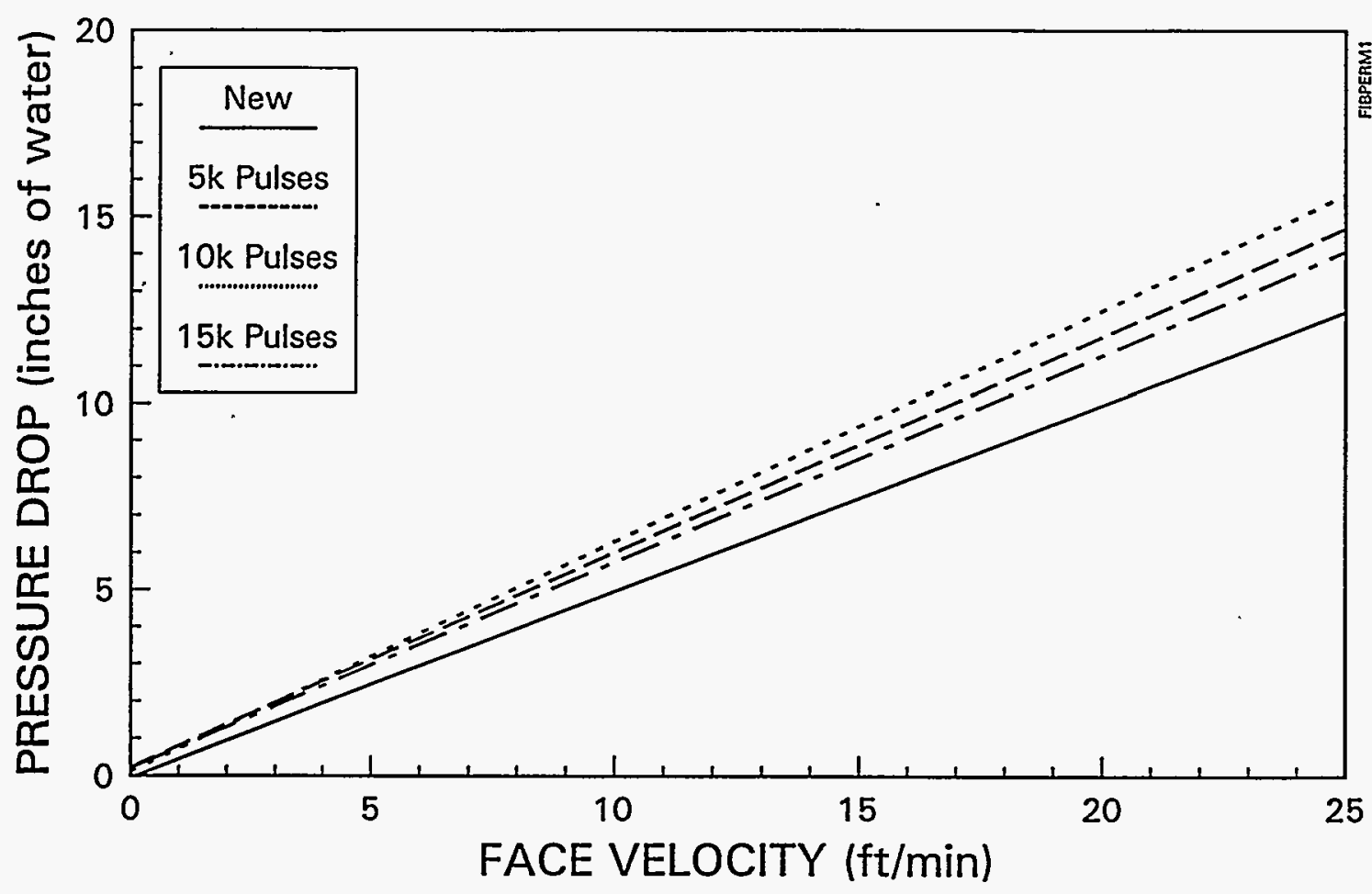

Figure 4-31. Fibrosic candle permeability: Accelerated pulse cleaning at $870^{\circ} \mathrm{C}$

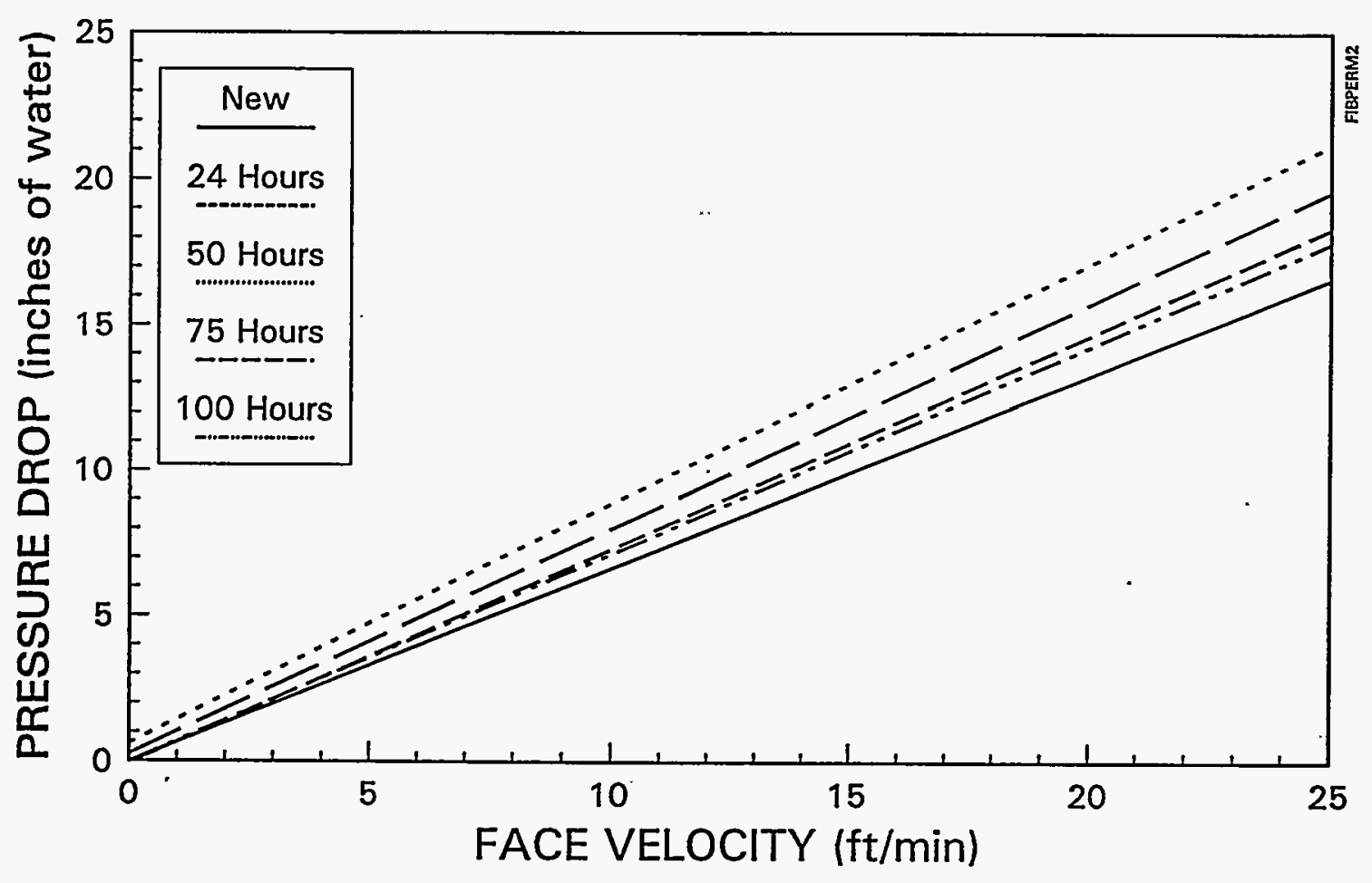

Figure 4-32. Fibrosic candle permeability: 100 hour operational filtration test at $870^{\circ} \mathrm{C}$ 
above). The tubesheet subjected to a loading similar to that expected from the filter, dust, and hold-down plate at $870^{\circ} \mathrm{C}$ for 500 hours. During the test, measurements of deflection of the tubesheet (via alumina rods) from the as received tubesheet as a function of time were performed. The measurements were performed manually with a pair of calipers.

Figure 4-33 shows the absolute value of displacement over time of the alumina rod that was extending up from the surface of the Fibrosic tubesheet and through the top of the oven. Figure 4-34 displays the locations on the tubesheet in which the alumina rod was situated. It can be seen in Figure 4-33 that the major displacement in the Fibrosic tubesheet occurred within the first 24 hours at $870^{\circ} \mathrm{C}$. Even after 500 hours, it appears there was still deflection (sagging) in the tubesheet. The raw data from the measurements of the alumina rods are in Appendix G.

Visual examination after removal of the tubesheet from the oven after load testing revealed some separation of the layers on the edge of the tubesheet. Since the tubesheet is in compression during operational use, however, this does not pose a problem. There were some small cracks observed on the bottom of the tubesheet as well as on the interior of some of the candle holes. Upon laying a straight edge across the width of the tubesheet section, a deflection of about 0.1 inches was observed.

Figure 4-35 shows the topographic map of the surface of the Fibrosic tubesheet. This topographic mapping is based on the edges of the Fibrosic tubesheet (across the width) defined as at the reference height of "0". Figure 4-36 shows an overlay of the topographic map on a drawing of the Fibrosic tubesheet to show which parts of the tubesheet are correlated by the topographic map. Figure 4-37 shows the three dimensional representation of the topographic map of the Fibrosic tubesheet surface (note the $\mathrm{Z}$-axis is not in the same scale as the $\mathrm{X}$ - and $\mathrm{Y}$ - axes). 


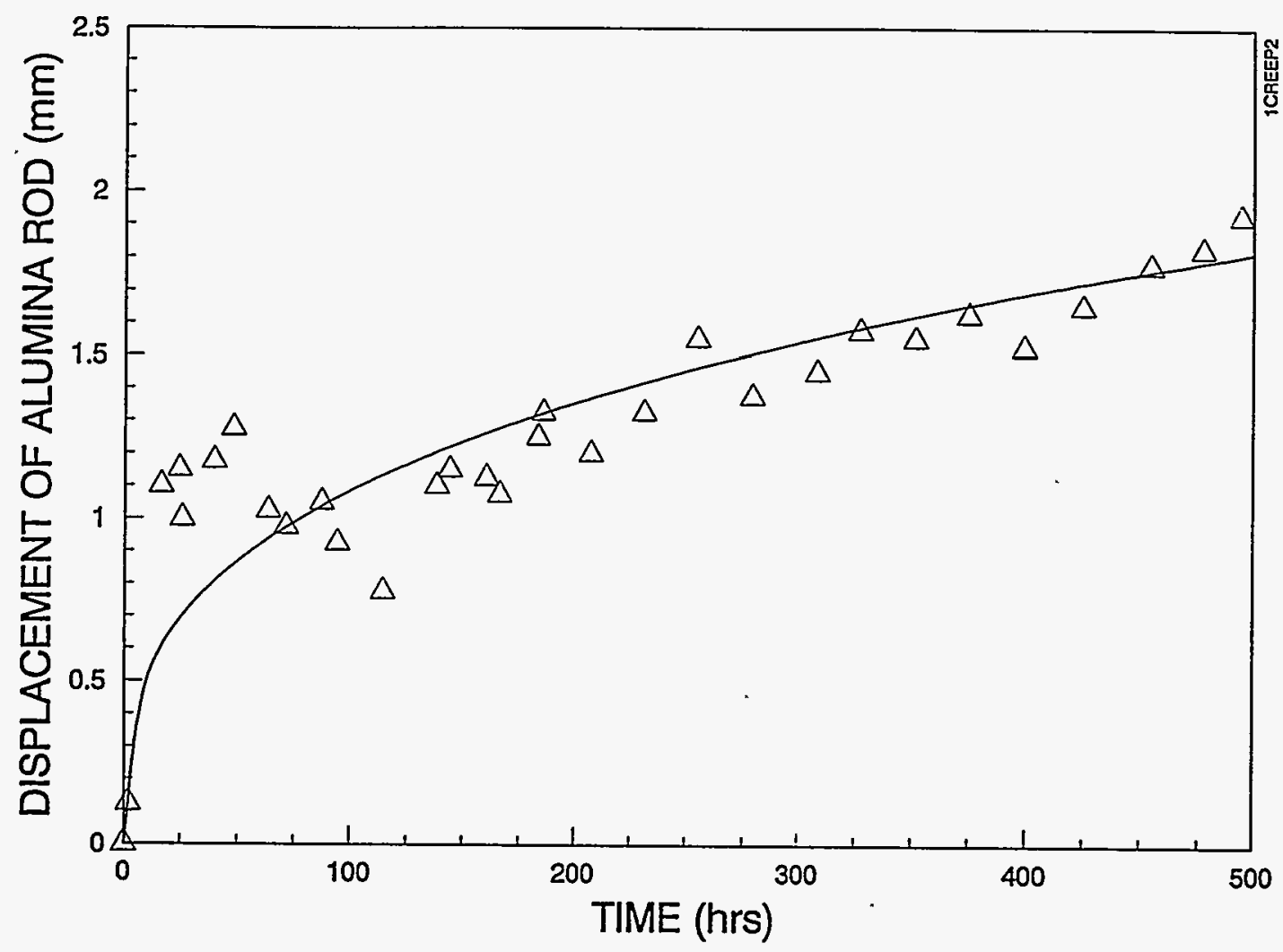

Figure 4-33. Displacement of an alumina rod on the surface of the Fibrosic tubesheet

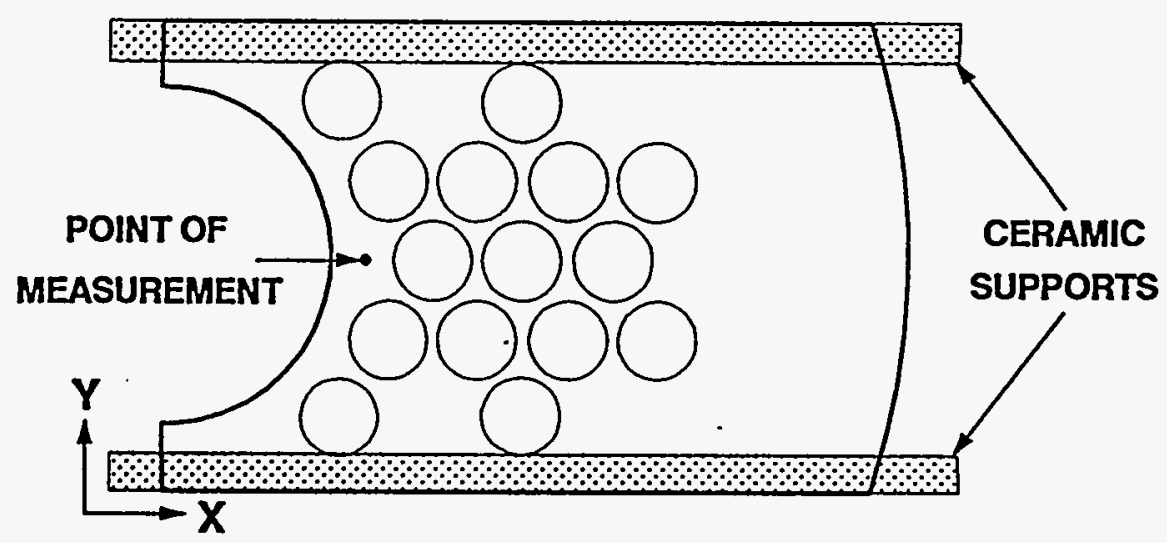

Figure 4-34. Location of alumina rod on Fibrosic tubesheet 


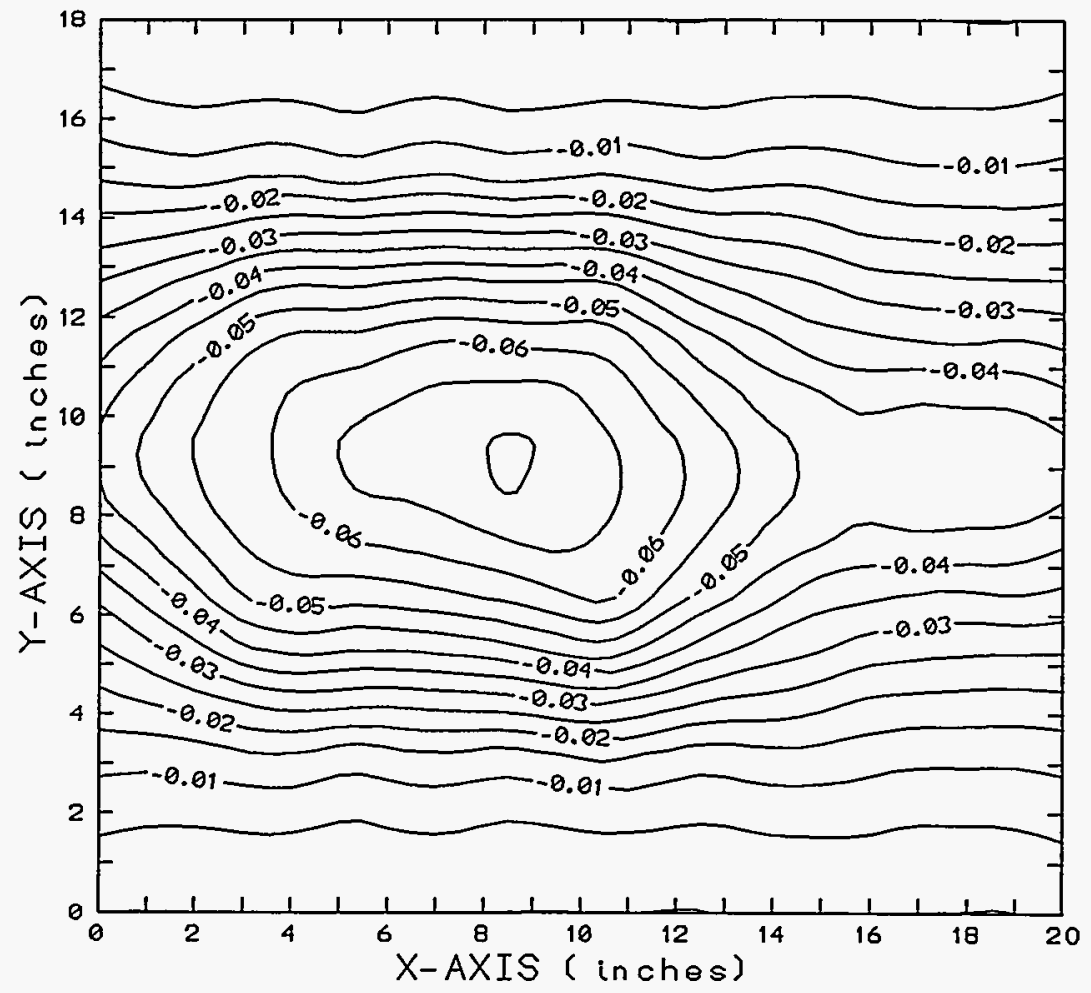

Figure 4-35. Topographic map of the Fibrosic tubesheet after load testing at $870^{\circ} \mathrm{C}$

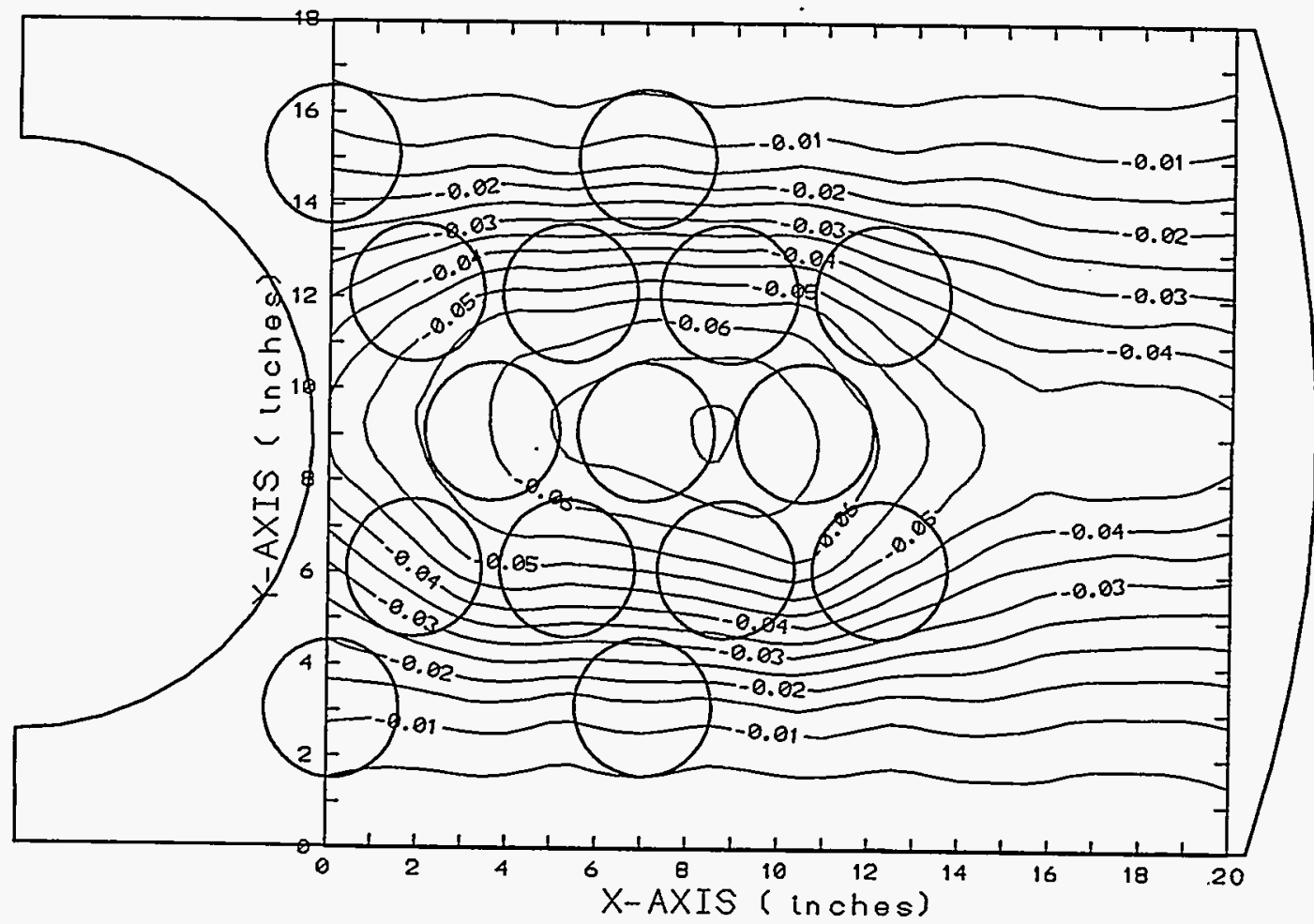

Figure 4-36. Overlay of topographic map with a drawing of the Fibrosic tubesheet 


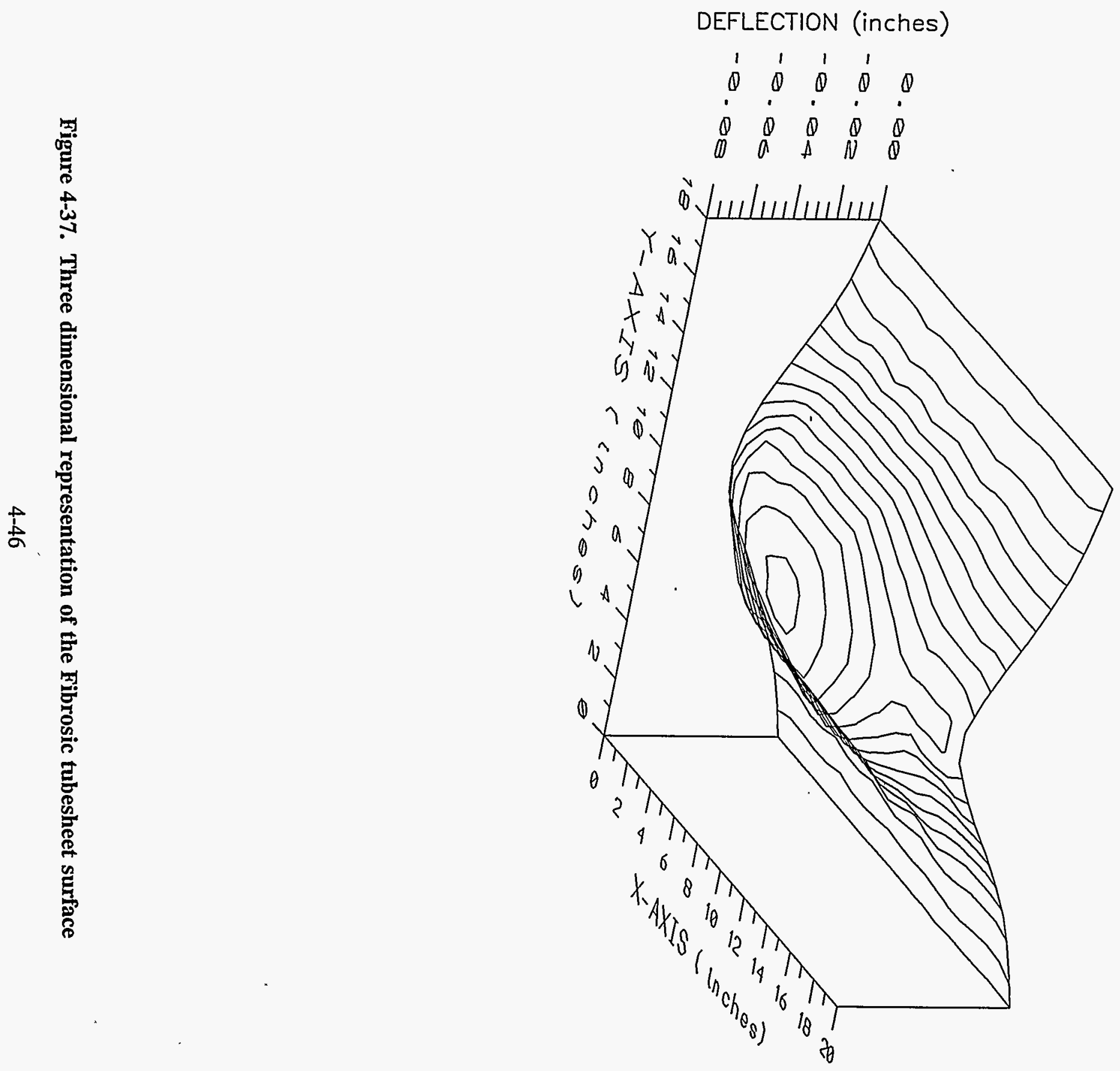

io 


\section{SECTION 5}

\section{CHEMICAL TEST RESULTS AND ANALYSIS}

Experiments at Virginia Polytechnic Institute (VPI) were performed (VPI were subcontracted and provided support to this project) to determine the response of commercially available ceramic particulate filters to the high-temperature environments of advanced coal conversion systems. The final reports prepared by VPI are supplied in Appendix H. The following is a summary of some of the analyses performed by VPI. The SiC candles examined were the Schumacher Diaschumalith, Didier SiC, and the IFP LayCer candle filters.

The SiC candle filter specimens were exposed to alkali-containing atmospheres at temperature ranging from 450 to $1,225^{\circ} \mathrm{C}$ and pressures ranging from atmospheric to $1,000 \mathrm{psi}$ (68 atm) for up to 24 hours. An alumina crucible containing either $\mathrm{Na}_{2} \mathrm{CO}_{3}$, or $\mathrm{K}_{2} \mathrm{CO}_{3}$ was placed in a box furnace and surrounded by test specimens. Upon firing, the alkali vaporized within the test environment.

At the end of 6-, 12-, and 24-hour exposures, to the evaporation of $\mathrm{Na}_{2} \mathrm{CO}_{3}$ and $\mathrm{K}_{2} \mathrm{CO}_{3}$ at atmospheric pressure, and temperatures of 925 and $1,225^{\circ} \mathrm{C}$, the $\mathrm{SiC}$ candle filter specimens displayed evidence of attack. The Didier specimens appeared slightly bloated and were coated with a glassy phase. The Diaschumalith specimens were also coated with a glassy phase and bloated, with the fibrous membrane areas of these specimens being more severely bloated. The membranes reacted more severely to the $\mathrm{K}_{2} \mathrm{CO}_{3}$ environment than to the $\mathrm{Na}_{2} \mathrm{CO}_{3}$ environment. Energy Dispersive X-ray analysis (EDX) identified the bloated membrane areas as 10 to $15 \%$ alkali, whereas little or no alkali was detected in interior portions of the samples. 
In hydrothermal testing, a filter sample was sealed in a platinum tube containing the required amount of $\mathrm{H}_{2} \mathrm{O}$ to generate the desired steam atmosphere. The sealed tube was placed in a pressure cell purged with argon gas, which served as a pressure medium and also prevented oxidation of the test cell. The pressure on the sample was applied through the steam generated inside the platinum tube. The total pressure at the testing temperature was calculated using the ideal gas law.

Following exposures to steam at 700 to $1,000^{\circ} \mathrm{C}$ and pressures of $200 \mathrm{psi}, 500 \mathrm{psi}$, and 1,000 psi for up to 20 hours, no visual evidence of degradation of any SiC specimens was observed. However, SEM examination of the Didier specimens indicated that melting and flowing of the bond phase had occurred in the steam atmosphere at $700^{\circ} \mathrm{C}$ and 200 psi and became more prominent with increasing temperature at this pressure. SEM examination revealed that bond melting and depletion had occurred in the Diaschumalith, Didier, and LayCer specimens exposed to steam at $700^{\circ} \mathrm{C}$, for the pressures of 500 and 1,000 psi.

Discoloration had occurred in the granular aluminosilicate following all steam exposure. However, XRD and SEM examination revealed no changes in specimens exposed at 700 to $1,000^{\circ} \mathrm{C}$ at 200 psi. Specimens exposed to 500 and 1,000 psi steam atmospheres at $1,000^{\circ} \mathrm{C}$, however, were deteriorated and crumbled upon handling. Phase identification by XRD showed cristobalite formation.

The chemical degradation of clay-bonded $\mathrm{SiC}$ candle filters in alkali-containing atmospheres appears to result primarily from the alkali attack on the bonding phase of the filters. The filter specimens exposed to the alkali-containing atmospheres at temperatures from 700 to $1,000^{\circ} \mathrm{C}$ showed varying degrees of bond melting and flowing.

The kinetics of sodium diffusion in the bonding (binder) phase of the clay-bonded SiC filters were investigated to predict sodium penetration and accumulation in the binder phase when exposed to a sodium-containing atmosphere. The aluminosilicate binder phase was approximated by a 76 $\mathrm{SiO}_{2}-16 \mathrm{AL}_{2} \mathrm{O}_{3}-8 \mathrm{P}_{2} \mathrm{O}_{5}$ (mol\%) fireclay glass, and the specimens used were core-drilled glass rods 
with dimensions of $6 \mathrm{~mm}$ in diameter and $5 \mathrm{~mm}$ long. Both ends of the glass pellets were polished flat to provide a defined boundary from which diffusion measurements were taken.

The alkali diffusion in the fireclay glass was evaluated at 800,900 , and $1,000^{\circ} \mathrm{C}$. The thin film method was used for diffusion annealing at $800^{\circ} \mathrm{C}$ in which a drop of $\mathrm{Na}_{2} \mathrm{CO}_{3}$ or $\mathrm{K}_{2} \mathrm{CO}_{3}$ was evaporated on one end of the fireclay glass pellet, leaving a thin film containing $\mathrm{Na}$ or $\mathrm{K}$ sources. The coated pellets were heated isothermally at $800^{\circ} \mathrm{C}$ for 96 hours. The alkali diffusion at 900 and $1,000^{\circ} \mathrm{C}$ was carried out by exposing the fireclay glass pellets at a constant alkali partial pressure generated by either $\mathrm{Na}_{2} \mathrm{CO}_{3}$ or $\mathrm{K}_{2} \mathrm{CO}_{3}$. The fireclay glass pellets in this case were wrapped in platinum foils so that diffusion occurred in only one direction. The alkali concentration of the exposed sample was measured as a function of diffusion distance using EDX. A series of spot analyses was performed along a line scan perpendicular to the exposed surface.

The resulting sodium diffusivities at 900 and $1,000^{\circ} \mathrm{C}$ are $3.7 \times 10^{-8} \mathrm{~cm}^{2} / \mathrm{s}$ and $7.1 \times 10^{-8} \mathrm{~cm}^{2} / \mathrm{s}$, respectively. The potassium diffusivities at 900 and $1,000^{\circ} \mathrm{C}$ were determined to be $7.5 \times 10^{-10} \mathrm{~cm}^{2} / \mathrm{s}$ and $3,2 \times 10^{-9} \mathrm{~cm}^{2} / \mathrm{s}$, respectively. The final reports supplied by VPI are in Appendix $\mathrm{H}$. 
$-98-$

This Page Intentionally Left Blank 


\section{SECTION 6}

\section{MODELING}

In attempts to provide modeling of the degradation mechanisms which predict candle degradation as well as candle lifetimes, attempts were made using theoretical framework and empirical observations of the data.

Solgasmix-PV is a chemical equilibrium program used for predicting the concentration of gas phase alkali species given the temperature, pressure, and the flue gas composition. The results of the program were to be used as input into the Virginia Polytechnic Institute (VPI) analyses to predict the lifetime of candle filters.

VPI developed a model based upon material loss due to reaction with alkalis. The reaction kinetics of mullite, cordierite, and aluminum titanate were examined in the presence of alkalis (in the form of $\mathrm{Na}_{2} \mathrm{O}$ ) via solid state reactions. The full report by VPI is presented in Appendix $\mathrm{H}$. The basic assumptions of VPI for this model were:

(1) Alkali reactions originate from the surface

(2) Alkali concentration in the atmosphere is equal to the alkali content in the solid state reactions

(3) New surface is exposed due to the spalling of the reacted layer

(4) No external forces applied

(5) Material loss rate is equal to the alkali reaction rate Summary of the VPI model are as follows:

(1) Time for consumption of $50 \%$ of the available mullite at $833^{\circ} \mathrm{C}: 40$ minutes

(2) Time for consumption of $50 \%$ of the available mullite at $1,065^{\circ} \mathrm{C}: 2$ minutes 
(3) Time for consumption of $50 \%$ of the available cordierite at $833^{\circ} \mathrm{C}: 20$ minutes

(4) Time for consumption of $>60 \%$ of the available cordierite at $>927^{\circ} \mathrm{C}$ : $<2$ minutes

(5) Time for consumption of $\approx 30 \%$ of the available cordierite at $833^{\circ} \mathrm{C}: 8$ minutes

(6) Time for consumption of $100 \%$ of the available cordierite at $927^{\circ} \mathrm{C}: 60$ minutes

The VPI model predicted that major candle changes would occur within minutes of exposure to an alkali atmosphere at high temperature and implies that the lifetime for the candle filter may be very short. The VPI model showed a very rapid penetration and consumption of alkali into the candle material. Attempts to correlate the VPI model with results from the thermal exposure tests proved unsuccessful. The poor correlation may have been due in part to the assumption that alkali uptake was only diffusion limited. The VPI model predicted major candle degradation to occur within a time scale of minutes, but the thermal/chemical exposure tests showed the candle degradation to occur on a time scale of days. The application of the VPI model probably is appropriate for the initial degradation of the candle (which shows a rapid drop in strength), but it apparently does not describe the long term degradation mechanisms which occurs gradually over a period of days.

In addition to the analytical modeling, attempts were made to relate empirical observations from the c-ring tests to knowledge of fundamental material characteristics and degradation mechanisms. Examination of the data as well as the qualitative behavior of the candles during testing may provide insight into the characteristics of the candles during operational conditions which may in turn produce a useful model of the contribution of thermal/mechanical stresses compared to chemical degradation mechanisms.

In examining the strength of unused Schumacher and Refractron candles at various temperatures, it was determined that the candles did not retain structural integrity at $980^{\circ} \mathrm{C}$. Figures 6-1 and 6-2 shows the strength (via c-ring tests) of unused Schumacher Diaschumalith F40 and Refractron 70/3 with 442-T binder candles at different temperatures. The decrease in strength could be attributed to the softening of the candle/binder material (refer to section 4.1.2 above). 


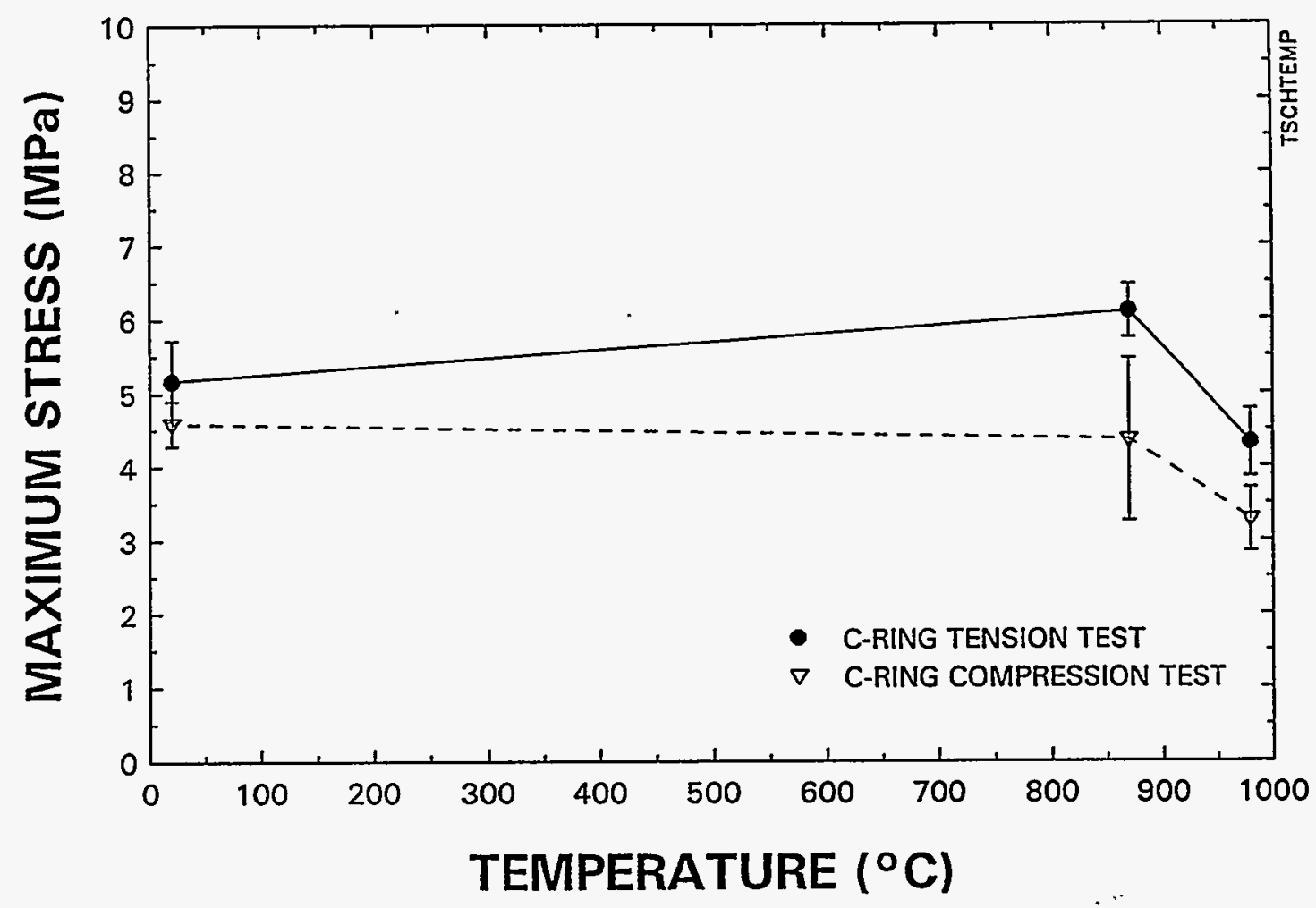

Figure 6-1. Unused Schumacher Diachumalith F40: c-ring tension and compression tests at various temperatures

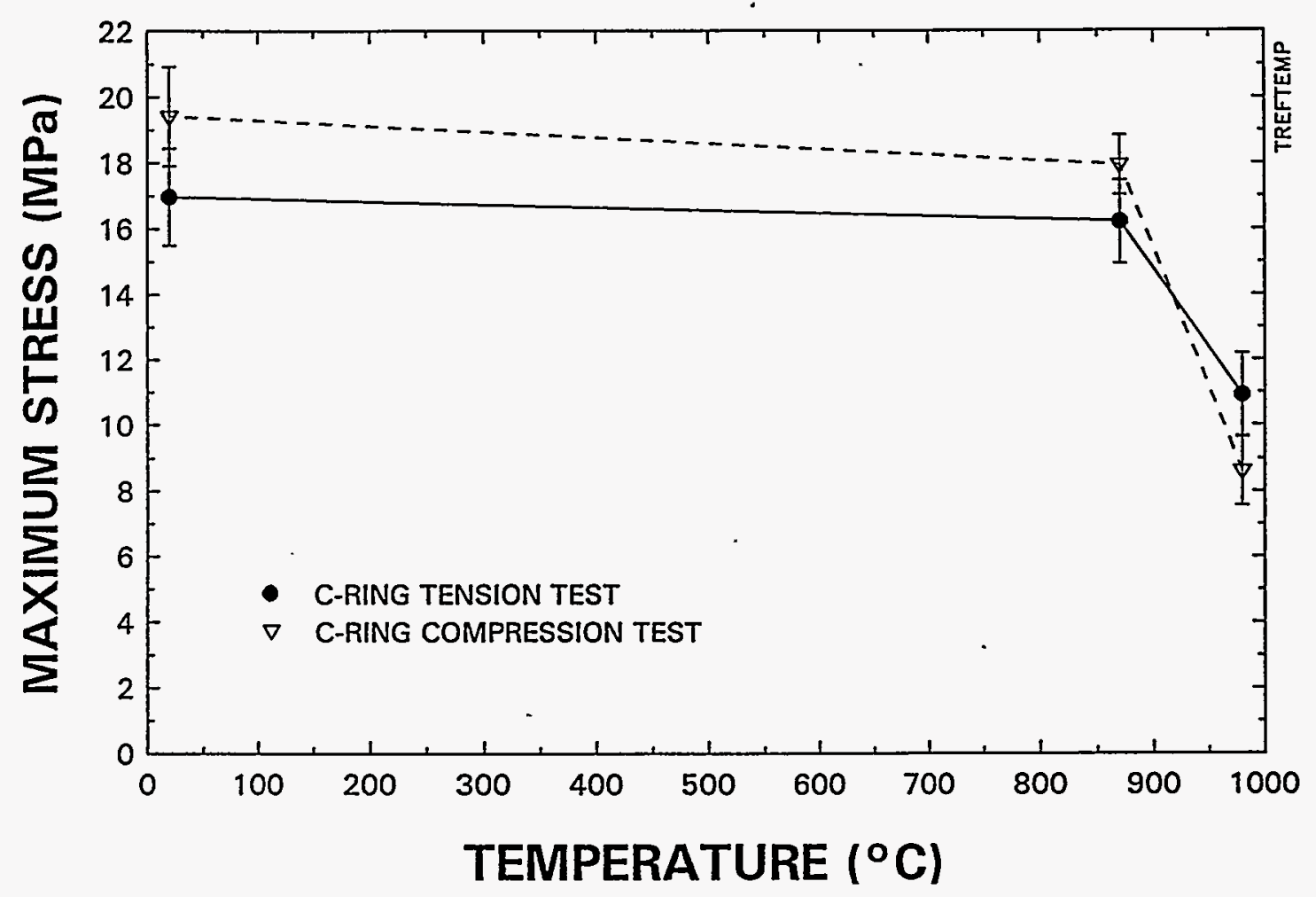

Figure 6-2. Unused Refraction 70/3 with 442-T binder: c-ring tension and compression at various temperatures 
When the softening temperature of the candle material is exceeded, the microcracks may be blunted and increase the toughness, but the ultimate strength of the candle may also decrease as a result. This viscoplastic behavior of the candles was observed at $980^{\circ} \mathrm{C}$ in both the Schumacher and the Refractron candles. At $980^{\circ} \mathrm{C}$, there was not the characteristic brittle failure (elastic up to the fracture stress) expected from a ceramic material. Brittle fractures of the c-rings were (generally) observed for specimens tested at $870^{\circ} \mathrm{C}$ and below. This would imply that the upper limit for the observed "healing" of candles (when tested at a crosshead rate of $0.05 \mathrm{in} / \mathrm{min}$ ) may be limited to temperatures ranging from $870^{\circ} \mathrm{C}$ to $980^{\circ} \mathrm{C}$. Further testing was performed to see if the transition temperature to viscoplastic behavior could be determined. A quick test in which one specimen was tested for each of the selected intermediate temperatures for the Schumacher candle were performed. Figure 6-3 shows the load versus displacement curves for this series of tests.

From Figure $6-3$, it appears that $\approx 920^{\circ} \mathrm{C}$ is the transition temperature for viscoplastic flow at a rate of $0.05 \mathrm{in} / \mathrm{min}$. A substance is viscoplastic if it exhibits both energy dissipation and energy storage in its mechanical properties (it would be viscoelastic if the deformation was recoverable after removal of all stress) ${ }^{14}$. For viscoplastic materials, the rate of testing would greatly influence the results.

Even at temperature as low as $500^{\circ} \mathrm{C}$, stress relaxation in the c-rings was observed (this would make creep deformation during long-term use a concern). This observation is based on loading a c-ring to a stress level below the failure stress and stopping the crosshead motion. At room temperature the c-ring (an unused Schumacher candle) sustained the load; but above $500^{\circ} \mathrm{C}$, the load dropped with time. When specimens display deformation (displacement of crosshead) without the expected linear increase in load characteristic of an elastic material, creep is said to have occurred. The flow of the material (probably due to binder softening) allowed stress release and thus reduced the structural integrity of the candle filters. Since this behavior is rate dependent, it is highly probable that changing the crosshead testing speed would result in a transition temperature different from the $920^{\circ} \mathrm{C}$ obtained from the crosshead speed of $0.05 \mathrm{in} / \mathrm{min}$. 


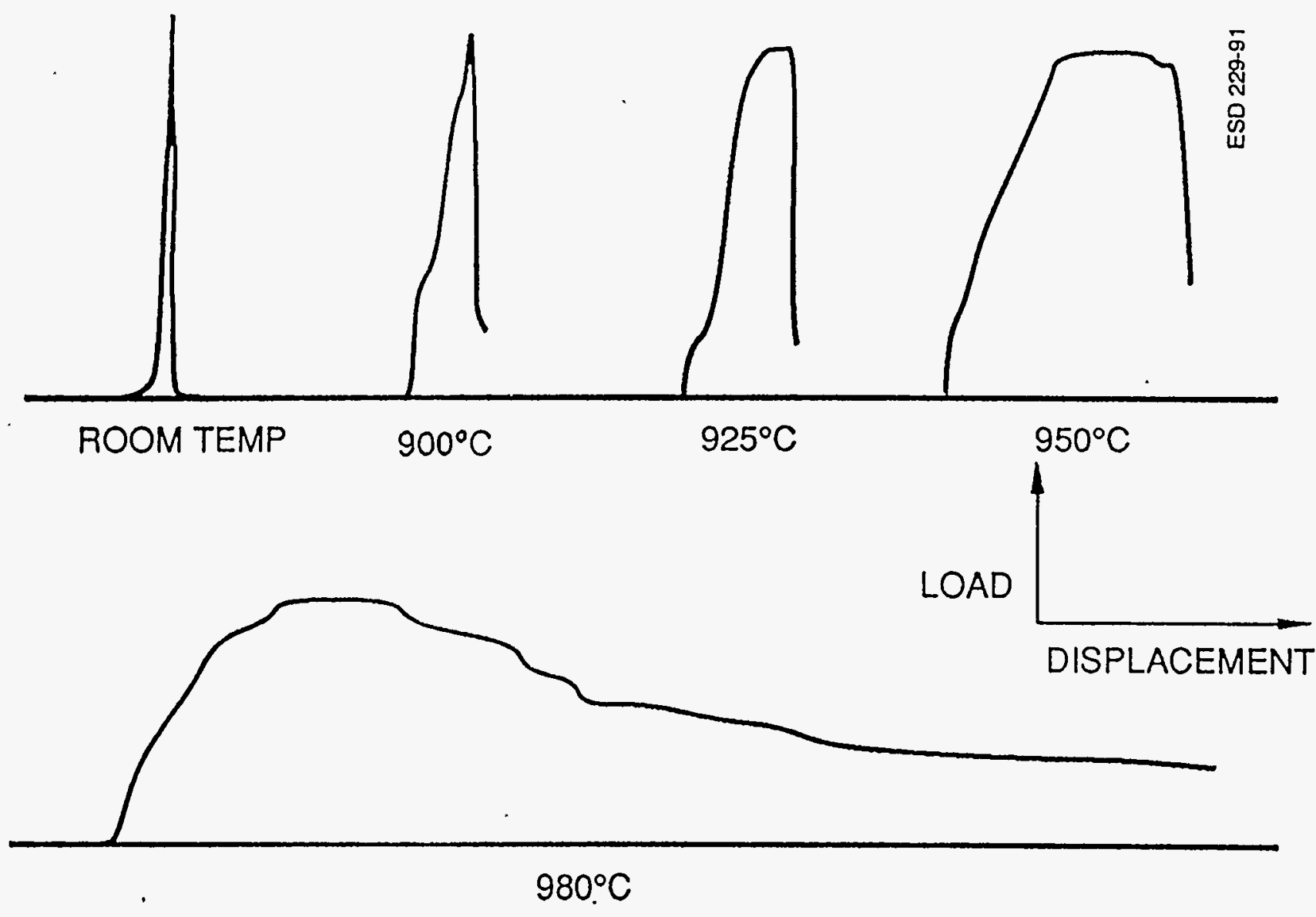

Figure 6-3. Load versus displacement curves for the Schumacher F40 at various temperatures

Figure 6-4 shows the percentage change of the strength of Schumacher candles from an unused Schumacher candle when tested at $870^{\circ} \mathrm{C}$. The candle that is only pulse cleaned (not exposed to any chemical degradation) shows about a $15 \%$ decrease in strength after 5,000 "0.5 second" pulse cleanings. The candle that was thermal/chemically exposed to $20 \mathrm{ppm} \mathrm{NaCl}, 870^{\circ} \mathrm{C}$, $15 \%$ steam, and pulse cleaned with 0.5 second pulses (every 30 minutes) shows a quick decrease in strength initially, but the degradation in strength appears to level off to approximately the same slope as the "pulsed only" candle. The thermal/chemical exposure candle specimens extends up to about 2,300 pulses (over 1,000 hours of exposure) and the remaining pulses on the graph were extrapolated out.

Figure 6-4 implies that the candle degradation is initially controlled by its chemical interaction with the candle environment, but as equilibrium is reached/approached, the thermal 


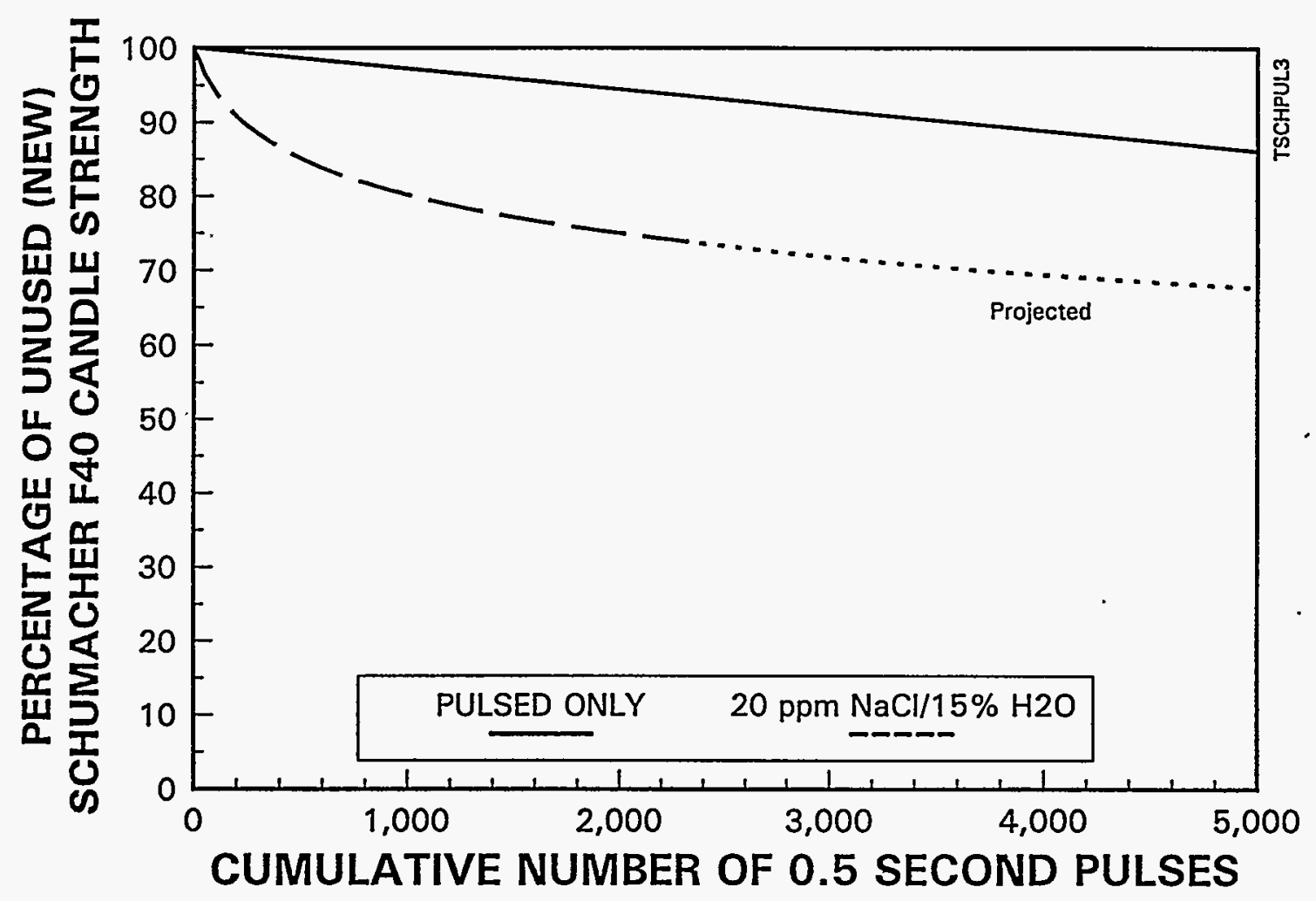
Figure 6-4. Schumacher F40/c-ring tension at $870^{\circ} \mathrm{C}$ : Strength soss due to
thermal and thermal/chemical degradation

degradation contribution (from pulse cleaning) to the candle's overall degradation becomes more significant.

Modeling of the degradation mechanisms of the candle filters is complex. As it can be seen in Figure 6-5, the strength of the Refractron $70 / 3$ with $442-\mathrm{T}$ binder appears to decrease with exposure at the $20 \mathrm{ppm} \mathrm{NaCl}, 870^{\circ} \mathrm{C}, 15 \%$ steam, and pulse cleaned $(2,400$ times with 0.5 second pulses every 30 minutes) condition, but it increases up to a strength greater than an unused candle. A possible explanation of this phenomena is the formation of albite (see Section 4.3). Albite apparently affects the characteristics of the Refractron candles. It had not been detected in any of the previous studies with the Schumacher candles. Another possible explanation of the increase in strength of the Refractron candles with exposure is the possible increased softening of the candle to the point where the candle material flowed (although major deformation of the candle at $870^{\circ} \mathrm{C}$ was not observed). Material could have flowed to a point where the candle became denser thus 


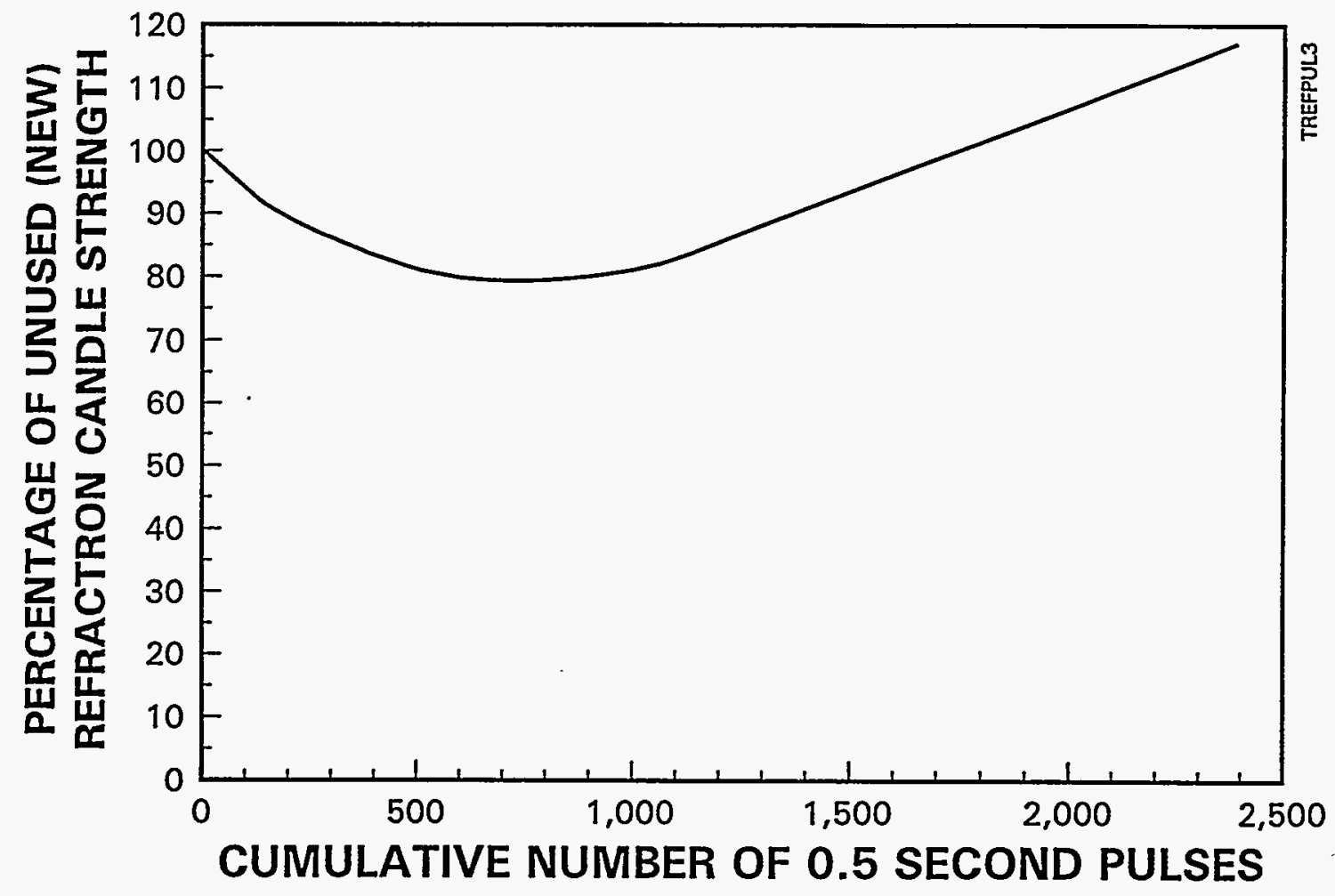

Figure 6-5. Refractron $70 / 3 \mathrm{w} / 442-\mathrm{T} / \mathrm{c}-$ ring tension at $870^{\circ} \mathrm{C}$ : Strength change due to thermal and thermal/chemical degradation

reducing porosity. This could cause the strength of the material to increase. Unfortunately, no tests were performed on the candle porosity and permeability. In another project performed by Acurex Environmental, Refractron 50/5 with 442-T binder candles exposed at the Solar Turbines Direct Coal-Fired Turbine Test Facility also showed the unexplained phenomena of increasing strength at high temperature. ${ }^{15}$ 
This Page Intentionally Left Blank 


\section{SECTION 7}

\section{CONCLUSIONS AND RECOMMENDATIONS}

\subsection{CONCLUSIONS}

Ceramic materials used in hot gas cleaning applications will be exposed to conditions that may degrade strength and limit service life due to thermal and chemical degradation. Further, the mechanical limitations of ceramic materials pose significant problems when such materials are exposed to dynamic environments. Based upon the tests and analyses of this project, the following conclusions can be stated.

\section{C-RING TESTS}

- C-ring testing proved to be the desired mechanical testing method for rigid candle materials because of the c-ring specimens retain the surface flaw population. For example, the c-ring specimens showed strength degradation for the KRW exposed candles, whereas the 4-point flexure tests did not show any strength loss.

- C-ring testing allows for separate evaluation of inner and outer surface strengths to investigate strength degradation from different environmental conditions.

- C-ring widths from 0.5 to 1.25 inches are representative of the strength of the candle material. The average maximum stress values (strength values) are more stable with widths greater than or equal to 0.75 inch.

- The optimum c-ring width is 0.75 inch. The 0.5 -inch specimen is more fragile than the 0.75-inch specimen. Using c-ring widths greater than 0.75 inch is an inefficient use of available material. 
- C-ring testing of the homogenous Didier SiC20 candle validated the c-ring stress equation because the strength for the inner and outer surfaces is the same.

- Machining of c-ring specimens during c-ring preparation does not significantly affect the strength measurement of the c-rings.

\section{THERMAL RATCHETING}

- Strength degradation due to room temperature air pulse cleaning of candles at high temperatures $\left(870^{\circ} \mathrm{C}\right)$ occurs with pulse durations greater than 0.05 second. Pulse durations of 0.05 second did not produce strength degradation.

- Strength degradation occurs with 0.5 second room temperature air pulse cleaning of candles at high temperatures $\left(870^{\circ} \mathrm{C}\right)$.

- At high temperatures, the $\mathrm{SiC}$ based ceramic candles showed increased toughness due to binder softening which blunted microcracks (relieving stress at the crack tips) resulting in increased strength.

\section{THERMAL/CHEMICAL EXPOSURE}

- The flow-through alkali thermal/chemical exposure experiments showed contamination from metals, such as $\mathrm{Fe}$ and $\mathrm{Cr}$, from the corrosion byproducts of the vessel and prevessel piping.

- There was evidence the binder became a viscous liquid at operating temperatures and flowed under gravity and aerodynamic drag to blind some of the pore structure of the exposed candles.

- The modeling of the thermal/chemical degradation mechanisms to predict filter lifetime was unsuccessful.

- Both the Schumacher Diaschumalith F40 and the Refractron 70/3 with 442-T binder candles did not retain their integrity when exposed at $980^{\circ} \mathrm{C}$. 
- Initially, the dominant degradation mechanism appears to be attributed to chemical degradation (alkali, metals, and/or steam), but the thermal/mechanical degradation (pulse cleaning) becomes the primary degradation mechanism.

Schumacher Diaschumalith F40

- Strength degradation was observed after 100 hours of exposure to $95 \mathrm{ppm} \mathrm{NaCl}, 20 \%$ steam, $870^{\circ} \mathrm{C}$, and without pulse cleaning.

- Strength degradation was observed due to $65 \mathrm{ppm} \mathrm{NaCl}, 20 \%$ steam, $980^{\circ} \mathrm{C}$, and with pulse cleaning.

- Strength degradation was observed only after 1,000 hours at $20 \mathrm{ppm} \mathrm{NaCl}, 15 \%$ steam, $870^{\circ} \mathrm{C}$, and with pulse cleaning.

- Cristobalite was detected only in the exposed candles at $980^{\circ} \mathrm{C}$. No cristobalite was detected in the unused Schumacher candle nor the candles exposed at $870^{\circ} \mathrm{C}$. - Crystalline silica was, however, detected in the exposed $870^{\circ} \mathrm{C}$ and $980^{\circ} \mathrm{C}$ candle specimens.

Refractron 70/3 with 442-T binder

- Strength degradation was observed after 100 hours at $20 \mathrm{ppm} \mathrm{NaCl}, 15 \%$ steam, $870^{\circ} \mathrm{C}$, and with pulse cleaning. Increase in strength for the 500-hour and 1,000-hour specimens was seen at the inner surface only.

- Strength degradation was observed due to $20 \mathrm{ppm} \mathrm{NaCl}, 15 \%$ steam, $980^{\circ} \mathrm{C}$, and with pulse cleaning.

- Albite formation was detected only in the exposed Refractron candles.

\section{FIBROSIC CANDLE TESTS}

- Both Fibrosic candles had collection efficiencies greater than $99.99 \%$ during and after the 15,000 pulse cleaning cycles and after 100 -hour operational filtration testing.

- The unused Fibrosic candle (Fibro2800) tested in this project has a burst pressure of $20 \mathrm{psig}$ as compared to the $16 \mathrm{psig}$ tested in an earlier version of the Fibrosic candle. 
- There was about a $25 \%$ drop in burst pressure for both of the Fibrosic candles tested as compared to the $50 \%$ burst pressure loss for the earlier version of the Fibrosic candle.

- Although a crack was discovered on the candle exposed to accelerated pulse cleaning, it did not affect the burst test strength of the candle (the failure occurred away from the crack).

- The permeability of the Fibrosic candle remained high throughout the tests.

\section{FIBROSIC TUBESHEET TEST}

- Minor cracks on the bottom side of the tubesheet were observed after loading with 113 pounds (using worst-case scenarios) and heating to $870^{\circ} \mathrm{C}$ for 500 hours.

- The major displacement of the tubesheet during load testing at $870^{\circ} \mathrm{C}$ occurred within the first 24 hours.

- Deflection in the tubesheet was still observed after 500 hours (but at a much slower rate than the first 24 hours).

- The Fibrosic tubesheet deflection/sag of about 0.1 inch (measured at the lowest point across the width of the tubesheet).

\subsection{RECOMMENDATIONS}

At the conclusion of this project, the following recommendations can be made:

- The results from the Fibrosics filtration testing look promising (high collection efficiencies, high permeability, and no catastrophic failure), but there was only one candle available for testing. Therefore the results are not statistically representative for describing the candle characteristics and properties under operating conditions. More candles should be tested to confirm the burst strength values and to determine if the crack discovered on the accelerated pulse cleaning candle specimen was an anomaly.

- Cylindrical burst strength tests need to be investigated to define the limitations, constraints, and applicability for strength measurements of candle filters. This is an 
issue because the burst strength test performed on a cracked candle did not fail at the site of the crack.

- Collection efficiency tests should be performed separately from permeability measurements to examine if the flyash used during collection efficiency tests affects the permeability measurements.

- Future studies on the effect of thermal/chemical degradation on candle filters should also include the measurement of porosity and permeability (possibly including collection efficiency) to ascertain whether the candle material retains filtration properties.

- Chemical modeling studies need to consider more than the diffusion limited case in the uptake of alkali. The modeling studies should also include kinetic mechanisms such as retention of some corroded material which will affect the surface area of new material for the continuation of alkali corrosion.

- Contact of alkali with piping materials leading into the thermal exposure vessel should be minimized, thus minimizing the exposure to corrosion byproducts that may affect the candle filters being tested.

- Extended exposure times to flow through testing at temperature without pulse cleaning. This data can be compared to the thermal/chemical degradation testing of candle filters which received thermal pulse cleaning at high temperature.

- A minimum of $5 \mathrm{c}$-ring specimens should be tested at each test condition in order to have a statistically significant strength value (having more specimens is desirable). 
This Page Intentionally Left Blank 


\section{REFERENCES}

1. Sawyer, J. W., "Assessment of the Causes of Failure of Ceramic Filters for Hot-Gas Cleanup in Fossil Energy Systems and Determination of Research and Development Needs." Acurex Environmental Final Report to ORNL under Subcontract IXX-57964C. January 1989.

2. Butterfield, D., D. J. Clinton, J. M. Cox, and R. Morrell, Characterisation of Silicon Carbide Filter Elements from the Grimethorpe PFBC Dust Filter, National Physical Laboratory (NPL) for British Coal, NPL Report DMA 650, May, 1988.

3. Ferber, M. K., V. J. Tennery, S. B. Waters, and J. Ogle, "Fracture Strength Characterization of Tubular Ceramic Materials Using a Simple C-ring Geometry", Journal of Materials Science, V. 21, 1986, pp. 2628-2632.

4. Butterfield, D., D. J. Clinton, J. M. Cox, and R. Morrell, Characterisation of Silicon Carbide Filter Elements from the Grimethorpe PFBC Dust Filter, National Physical Laboratory (NPL) for British Coal, NPL Report DMA 650, May, 1988, pp. 3-6.

5. Avallone, E. A. and T. Baumeister III, Mark's Standard Handbook for Mechanical Engineers, 9th ed., McGraw-Hill Book Company, New York, 1987, pp. 5-44 to 5-46.

6. Spiegel, M. R., Schaum's Outline of Theory and Problems of Statistics. Second Edition. McGraw-Hill. 1990.

7. Cullity, B. D., "Elements of X-ray Diffraction," second edition, Addison-Wesley Publishing, Reading, Massachusetts, 1978.

8. Communication with Paul Eggerstedt of Industrial Filter \& Pump in February, 1994

9. Stinton, D. P., Assessment of the State of the Art in Machining and Surface Preparation of Ceramics, Oak Ridge National Laboratory for U.S. DOE under contract DE-AC0584OR21400, ORNL Report ORNL/TM-10791, November, 1988.

10. Kingery, W. D., H. K. Bowen, and D. R. Uhlmann, Introduction to Ceramics, 2nd Ed., John Wiley \& Sons, New York, pp. 817-822.

11. Kingery, W. D., H. K. Bowen, and D. R. Uhlmann, Introduction to Ceramics, 2nd Ed., John Wiley \& Sons, New York, pp. 785-787.

12. Hertzberg, R. W., Deformation and Fracture Mechanics of Engineering Materials, 3rd Ed., John Wiley \& Sons, New York, 1989, pp. 271-277. 
13. Kingery, W. D., H. K. Bowen, and D. R. Uhlmann, Introduction to Ceramics, 2nd Ed., John Wiley \& Sons, New York, pp. 589-591.

14. Kingery, W. D., H. K. Bowen, and D. R. Uhlmann, Introduction to Ceramics, 2nd Ed., John Wiley \& Sons, New York, pp. 770-773.

15. Chan, M., and J. Sawyer, "Evaluation of Refractron Candles Exposed in the Solar Turbines Direct Coal-Fired Turbine Test Facility," Acurex Environmental Project No. 6675, Acurex Environmental Report No. FR-93-117, DOE contract No. DE-AP21-92MC36938, August 1993. 
$-115-$

\section{APPENDIX A}

THERMAL EXPOSURE SAMPLE VESSEL DRAWINGS 
$-116-$

This Page Intentionally Left Blank 


$$
-117-
$$

\section{APPENDIX B}

DRAWINGS OF C-RING TESTING FIXTURES

B-1 
This Page Intentionally Left Blank 


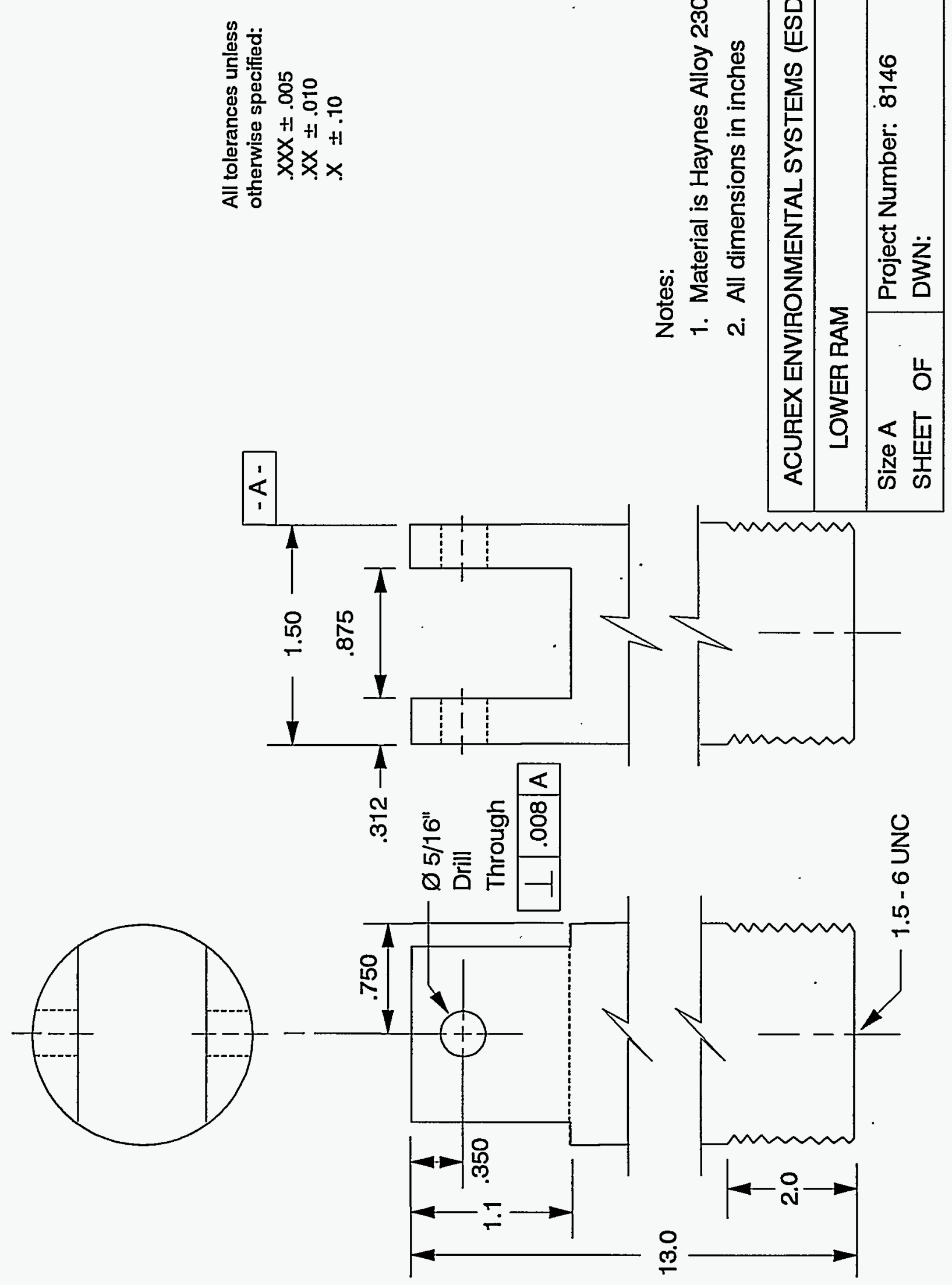




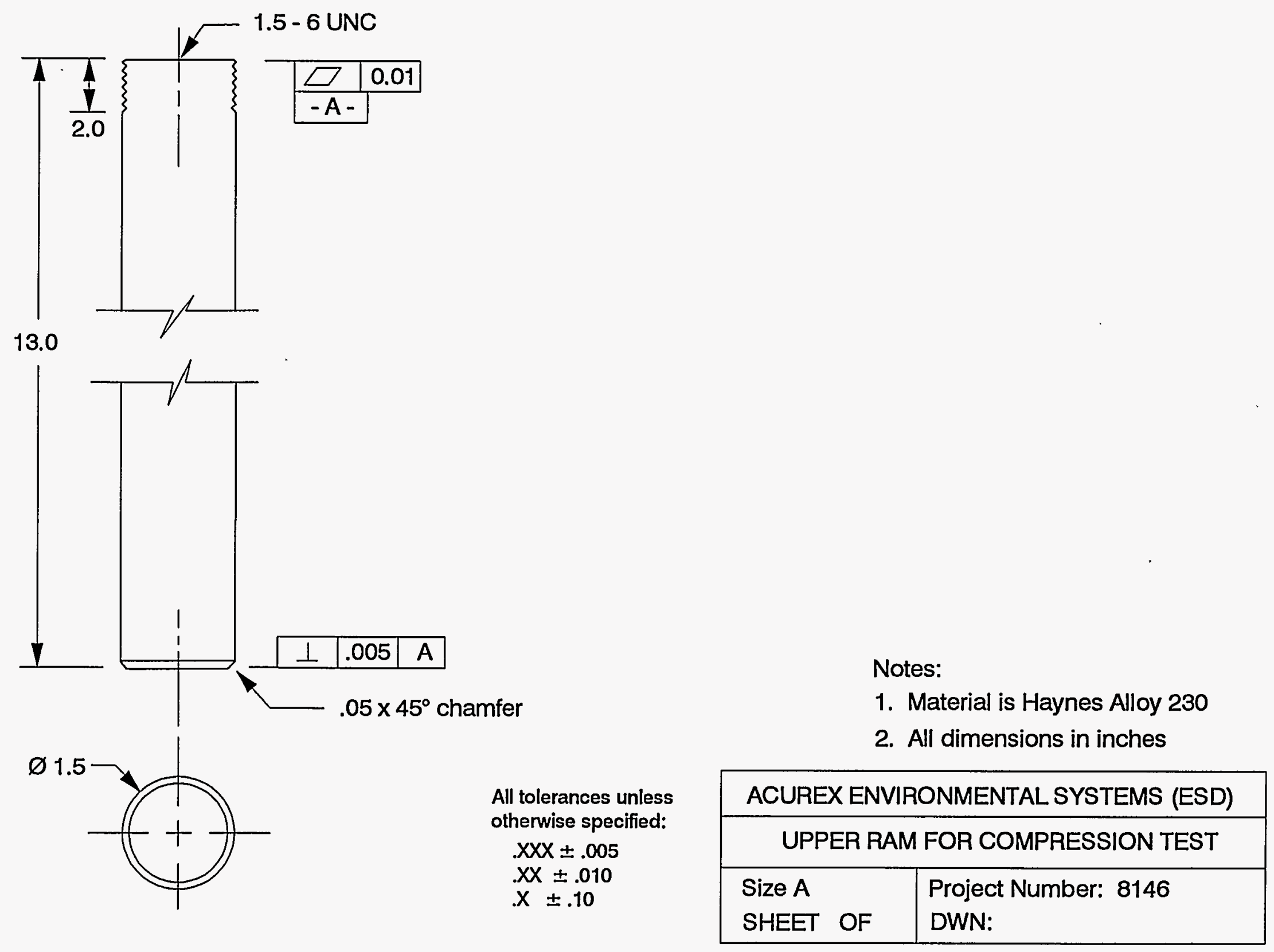

Notes:

1. Material is Haynes Alloy 230

2. All dimensions in inches

All tolerances unless Al torwise specified:

$x \pm .010$

$x \pm .10$ 


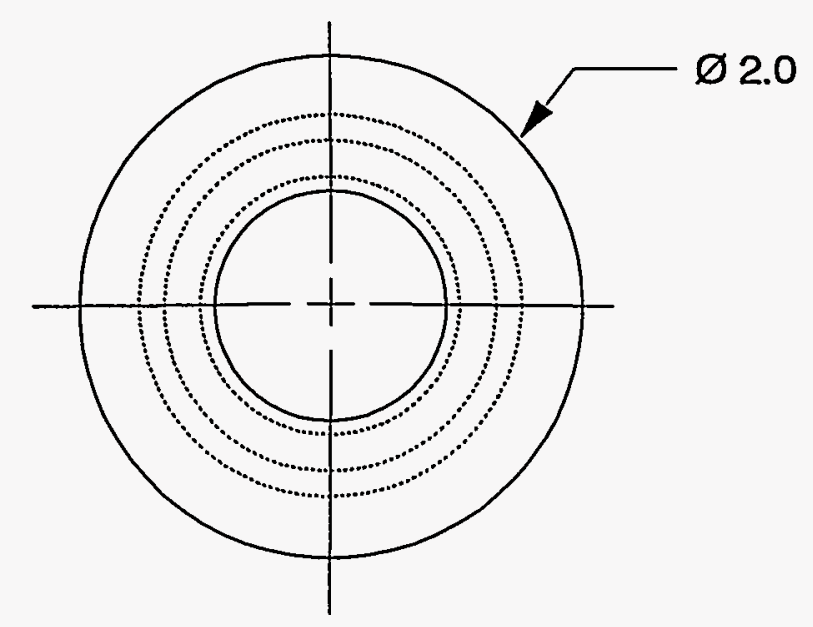

All tolerances unless otherwise specified: $. X X X \pm .005$ $X X \pm .010$ $\mathrm{X} \pm .10$

Notes:

1. Material is

2. All dimensions in inches

3. Quantity required is 2

\section{ACUREX ENVIRONMENTAL SYSTEMS (ESD)}

ADAPTER COUPLE FOR UPPER RAM (COMPR.)

Size A

Project Number: 8146

$1.5-6$ UNC

SHEET OF

DWN: 


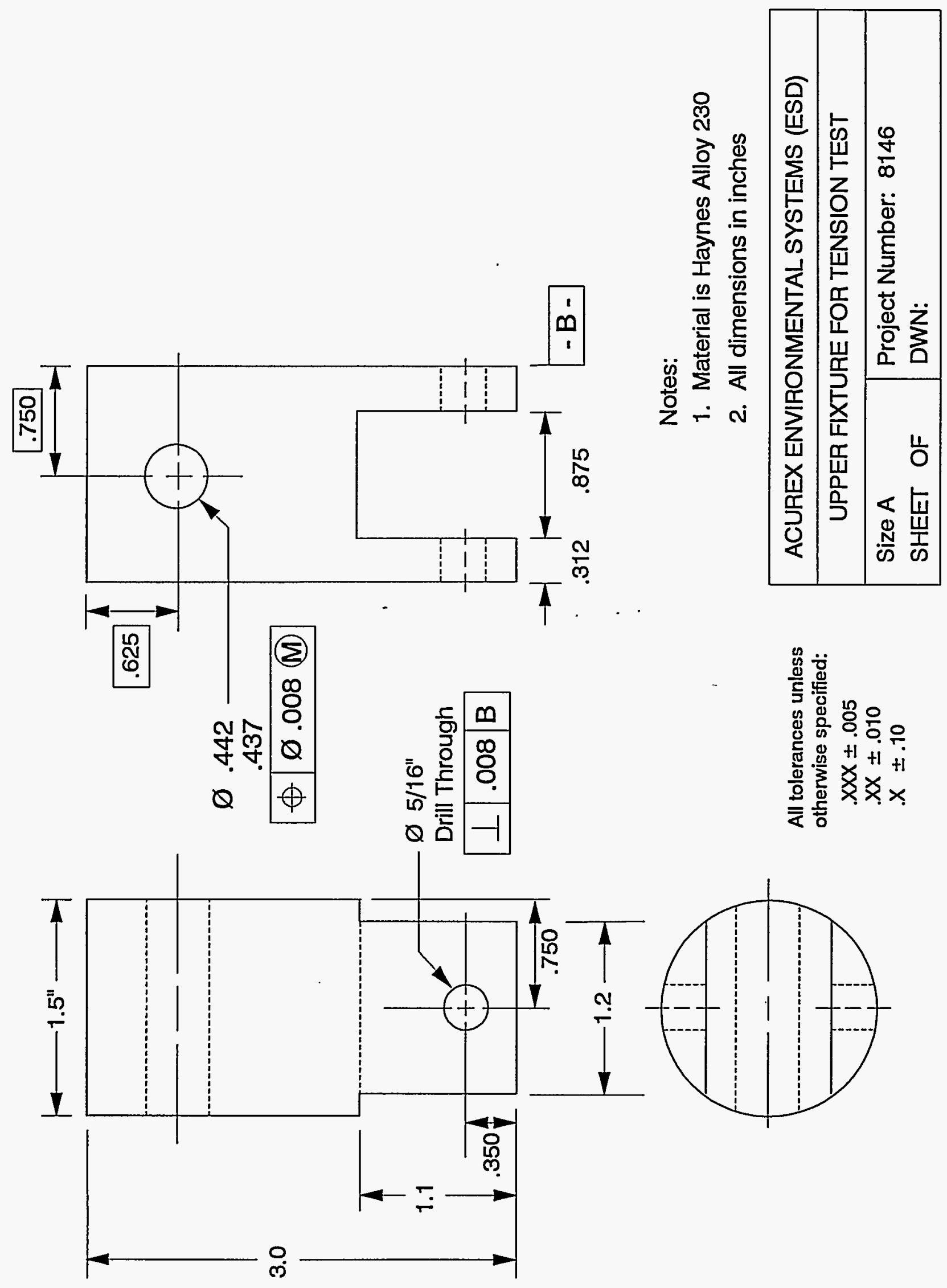




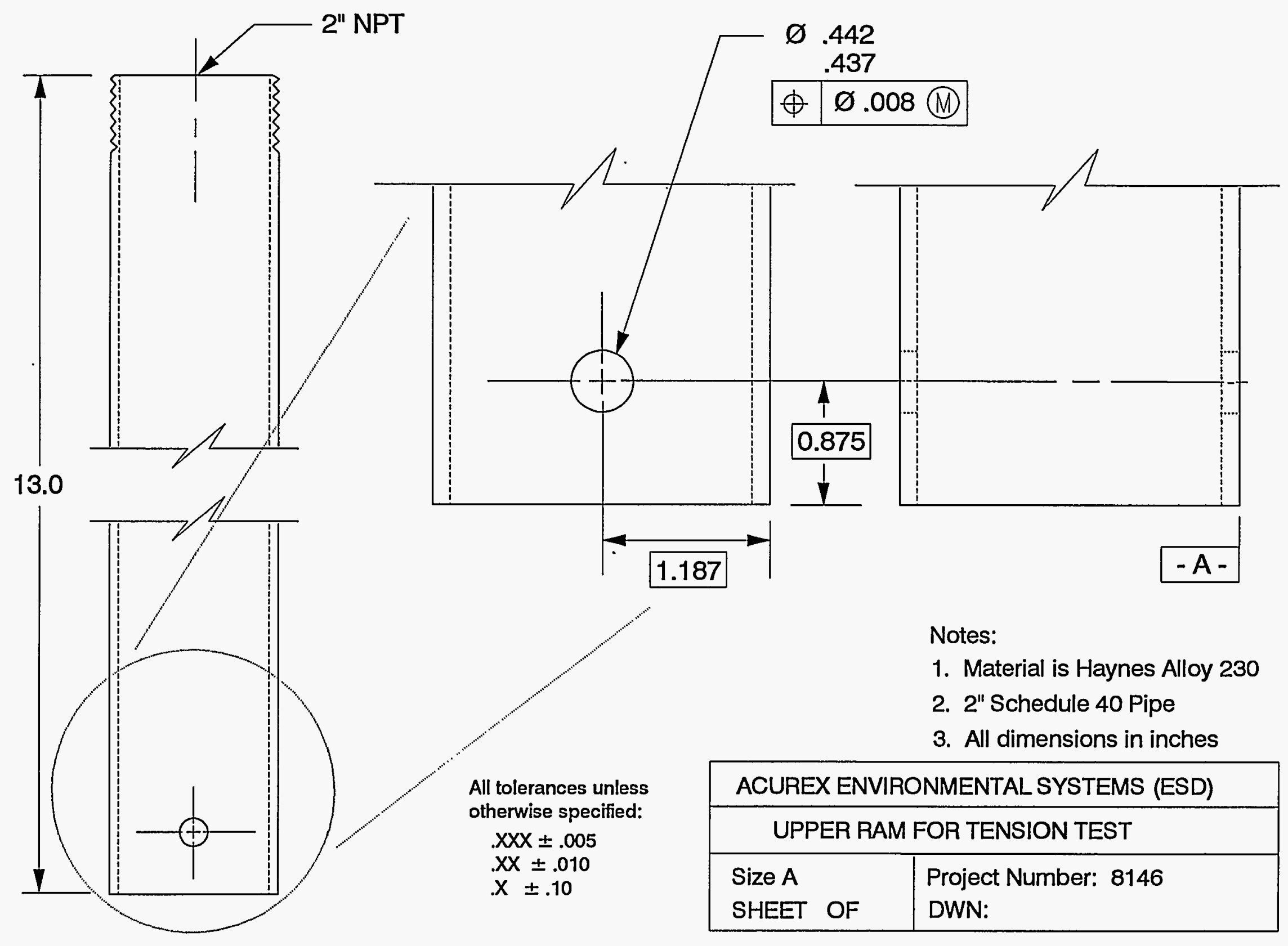




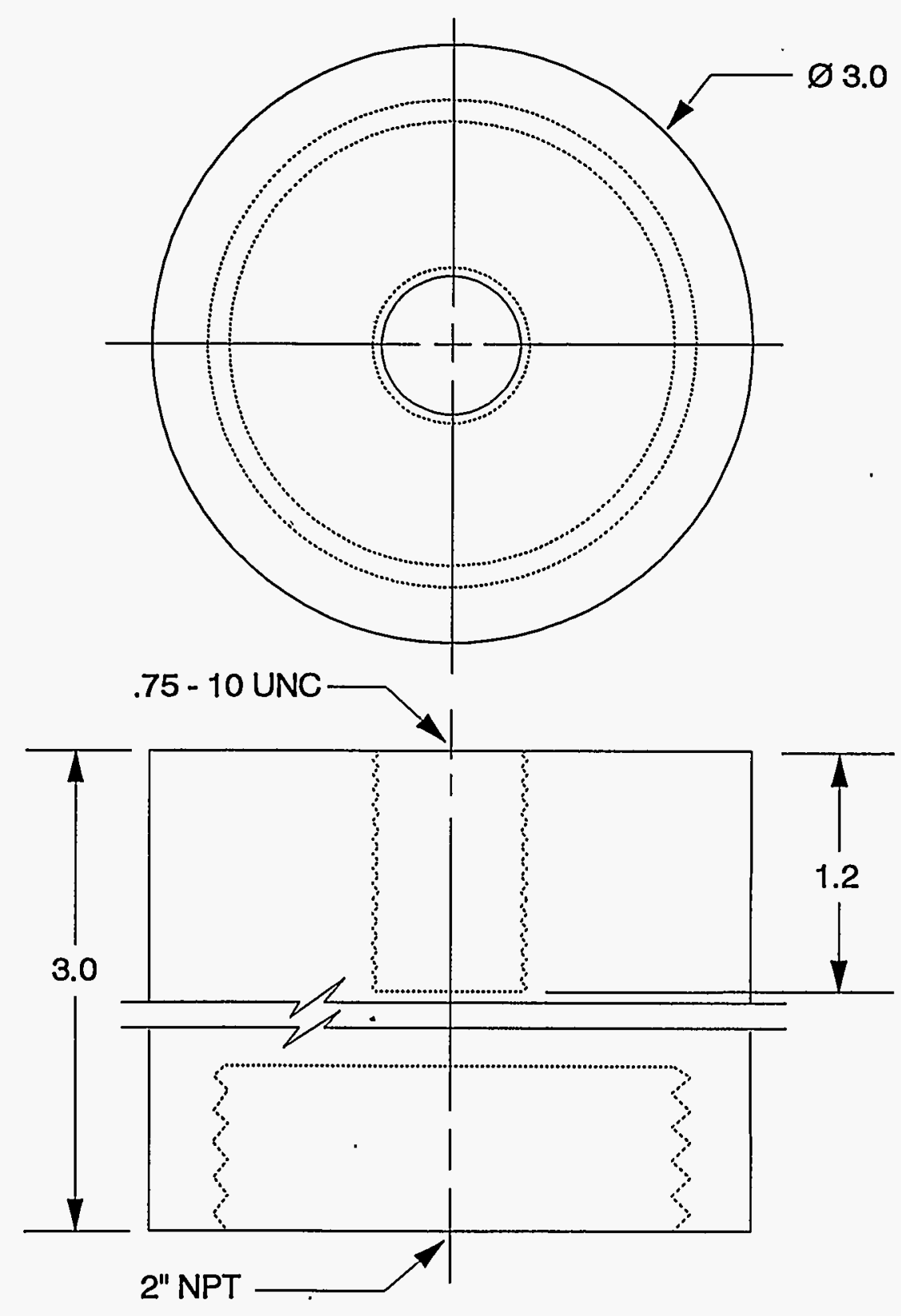

All tolerances unless otherwise specified:

$. X X X \pm .005$

$. X X \pm .010$

$x \pm .10$

Notes:

1. Material is

2. Female 2" NPT for a 2" Schedule 40 Pipe

3. All dimensions in inches

ACUREX ENVIRONMENTAL SYSTEMS (ESD)

ADAPTER COUPLE FOR UPPER RAM (TENSION)

\begin{tabular}{l|l} 
Size A & Project Number: 8146
\end{tabular}

SHEET OF - DWN: 


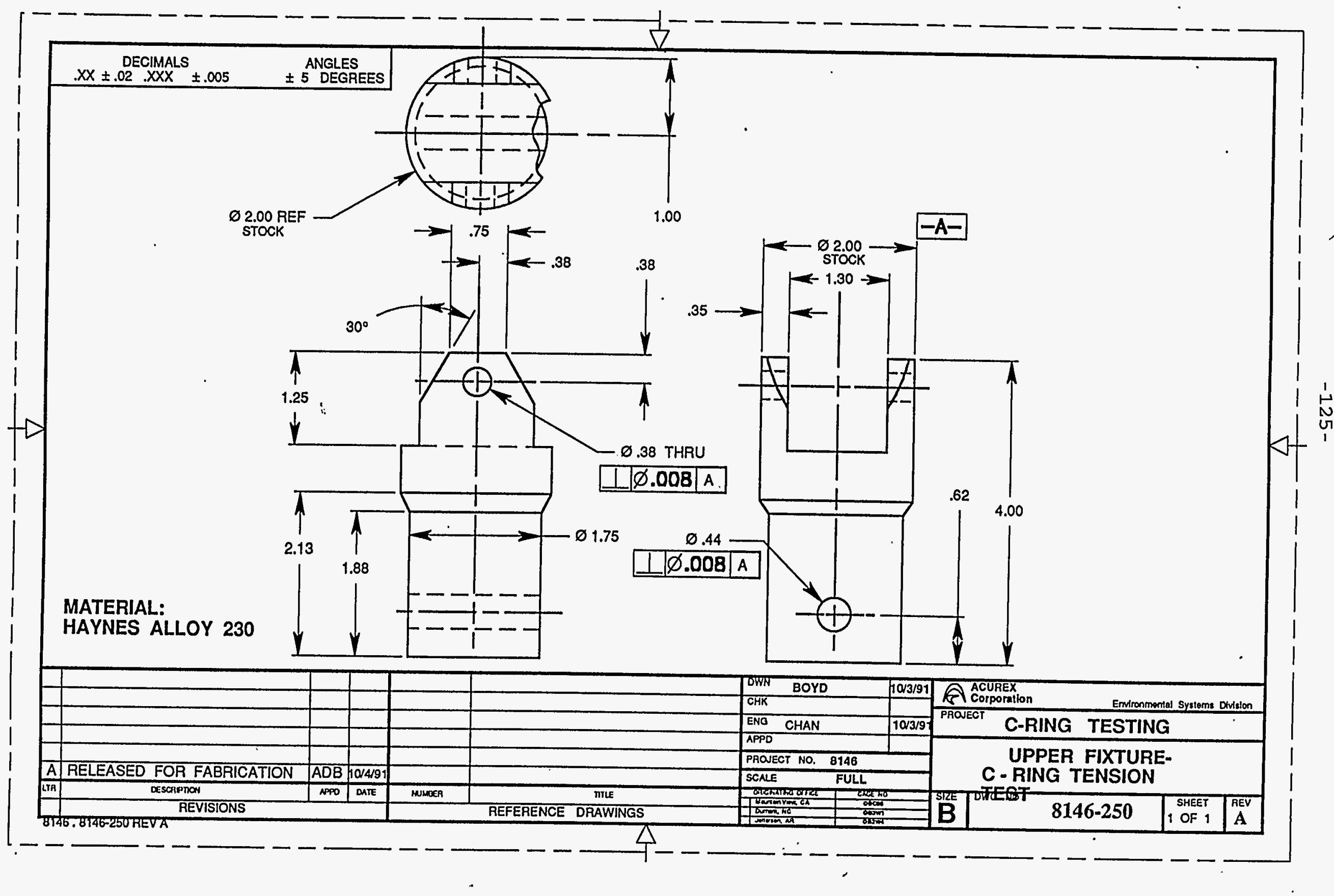




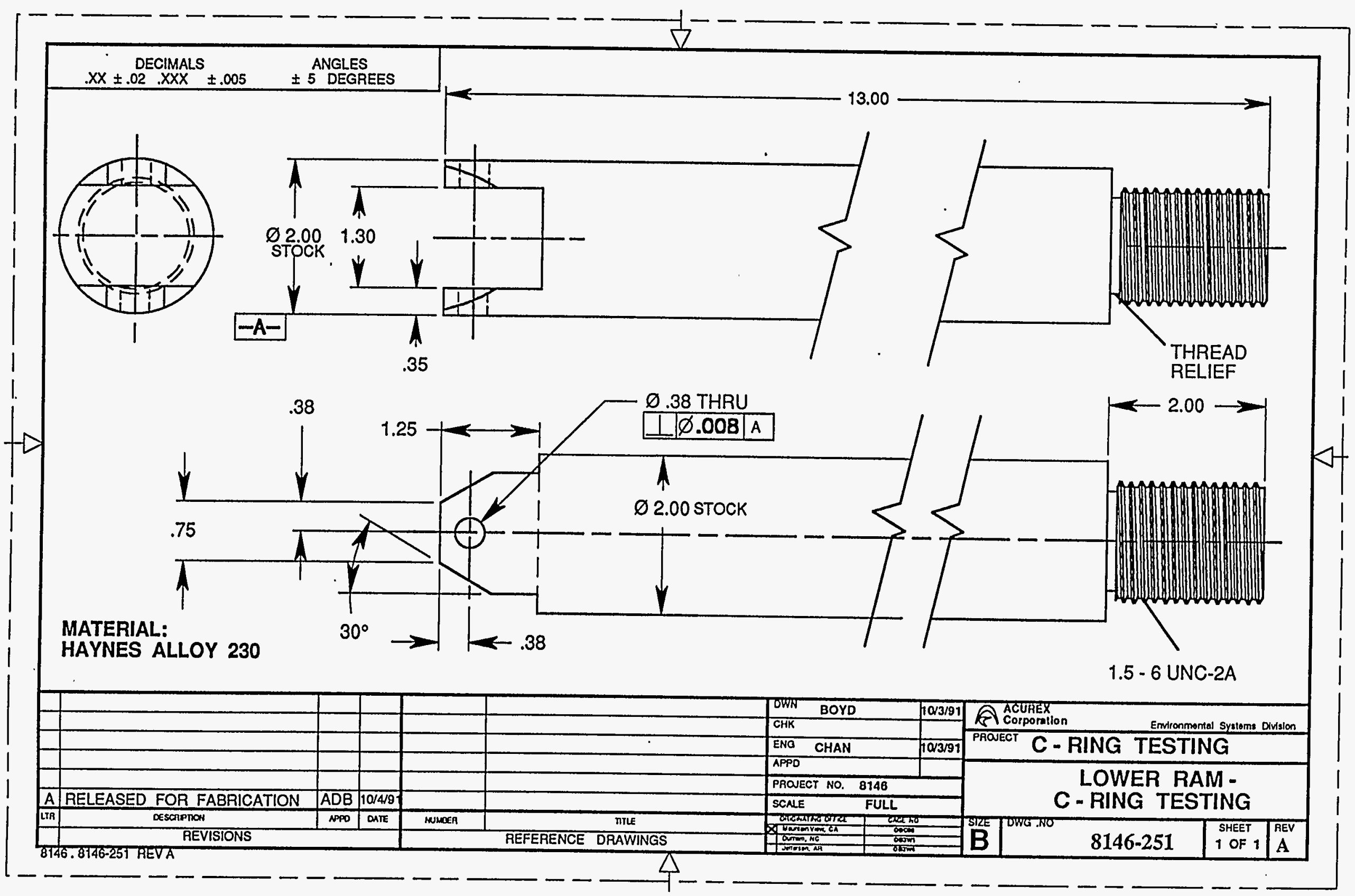




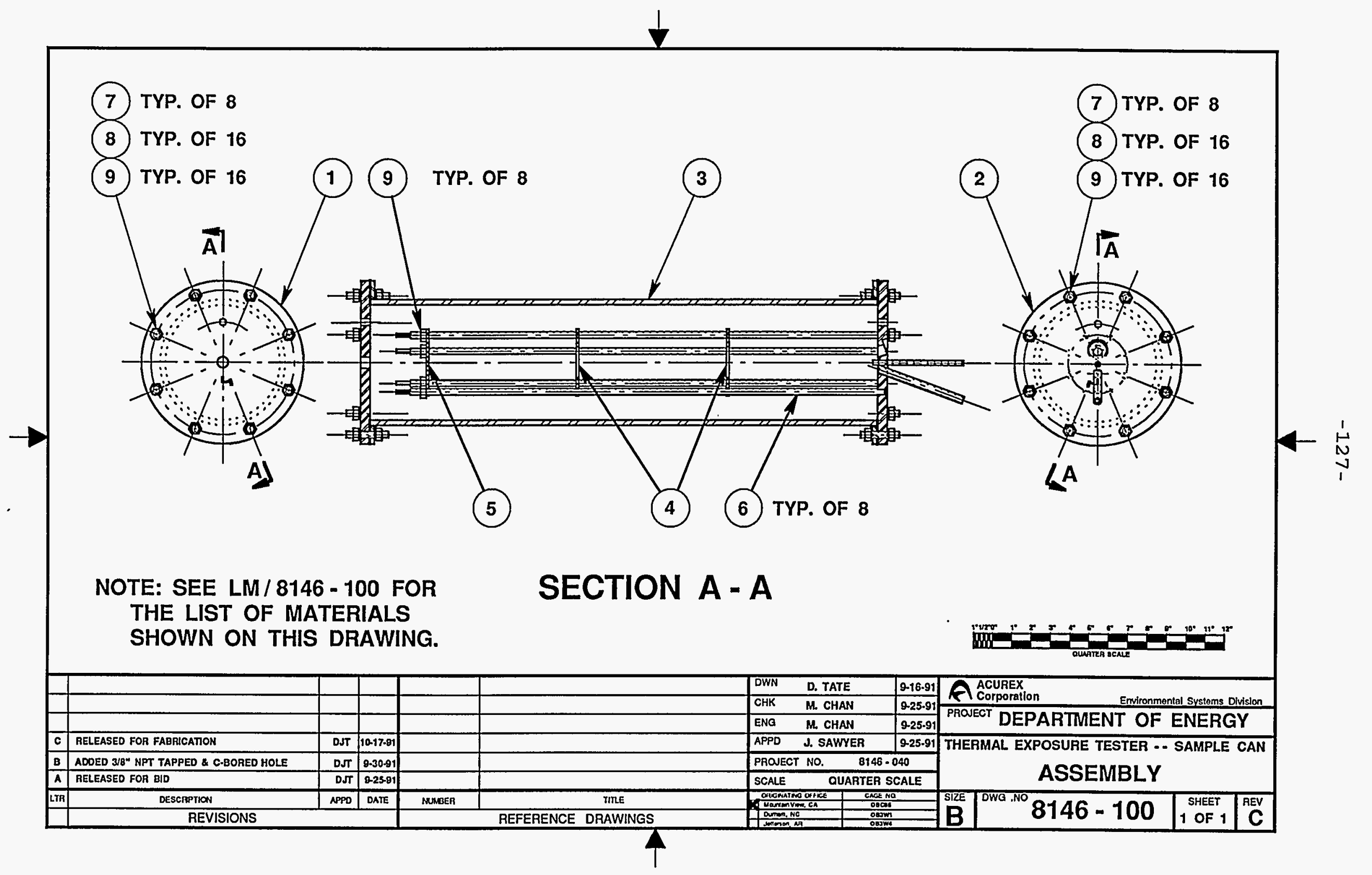




$$
-128-
$$

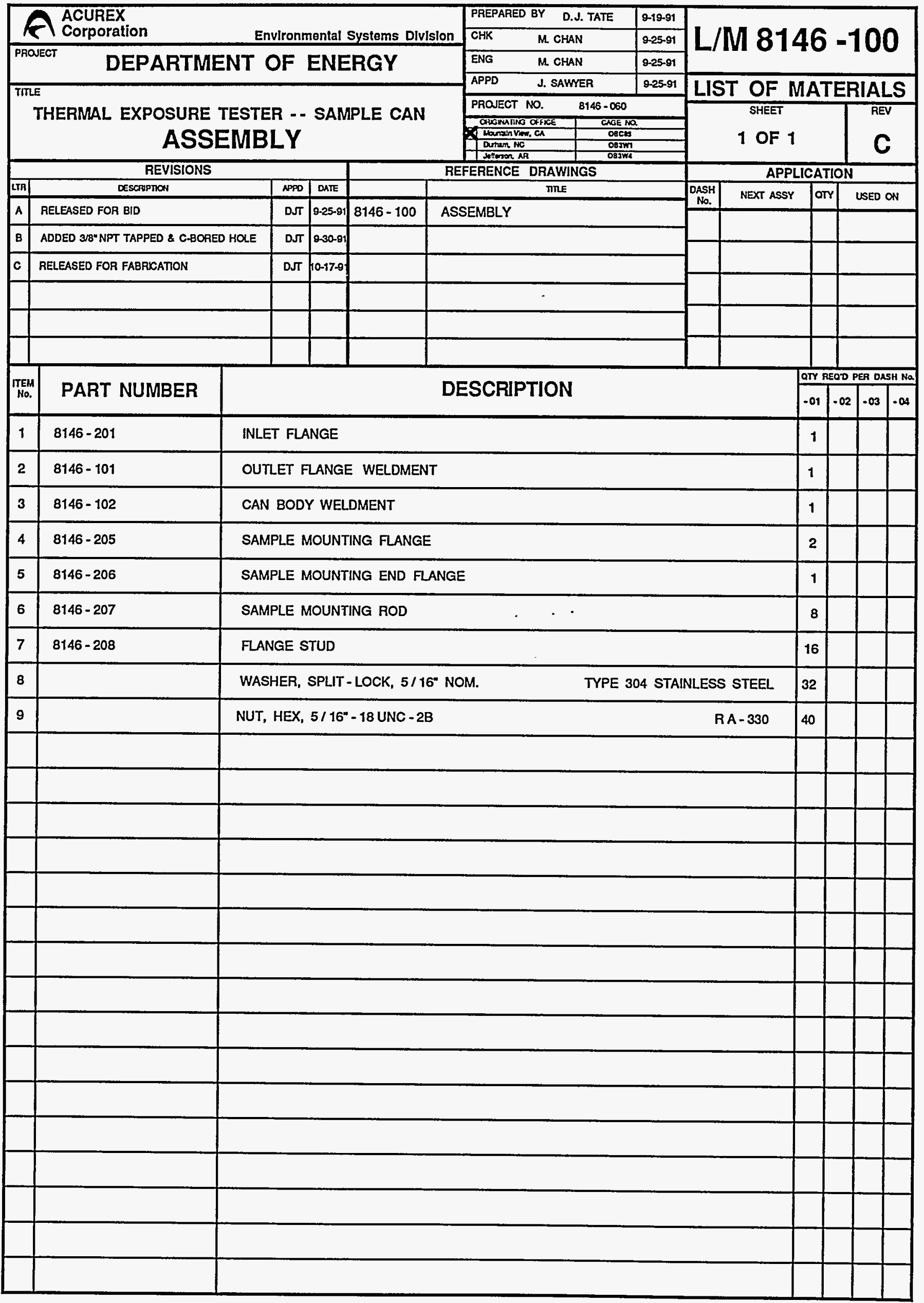




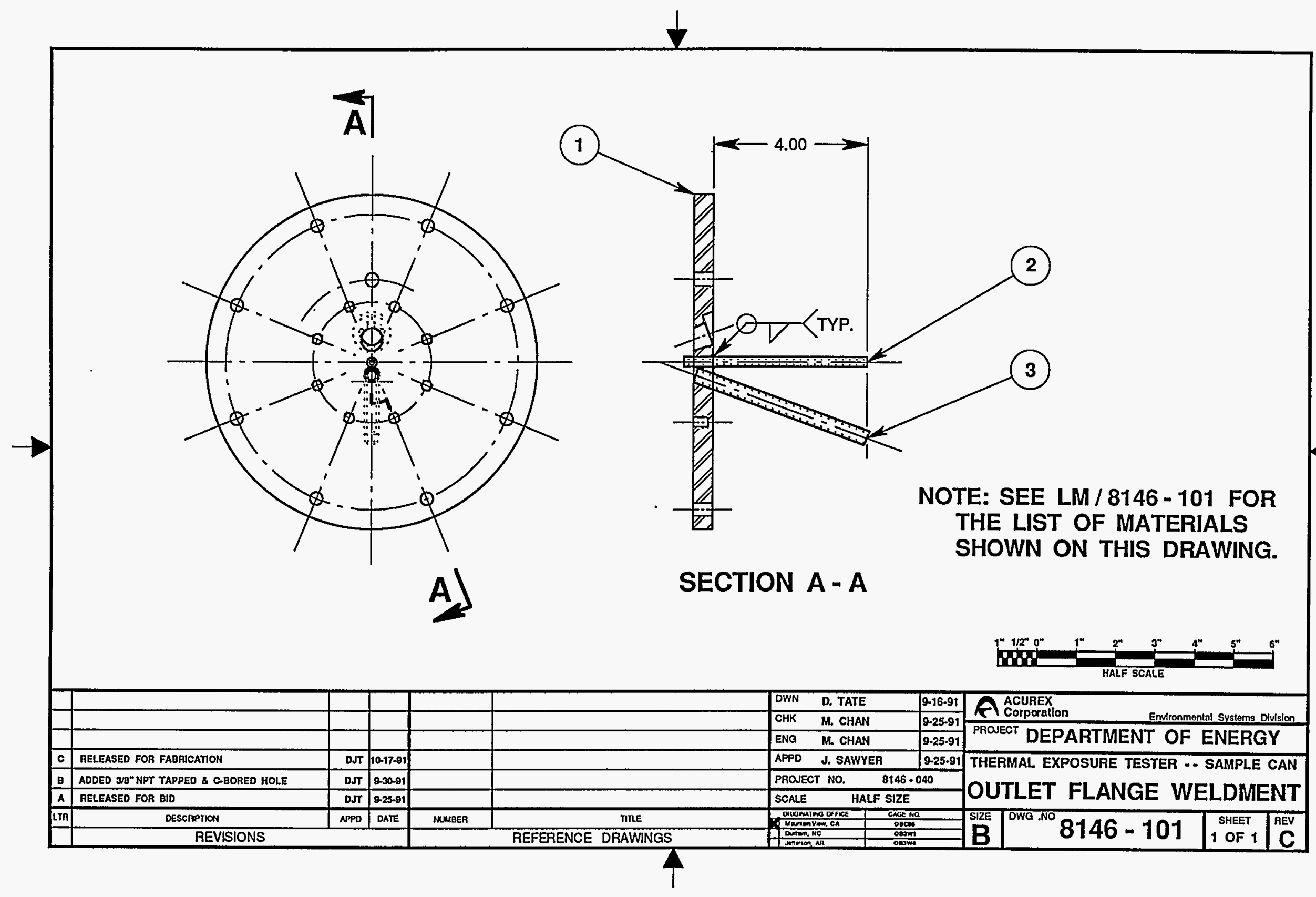




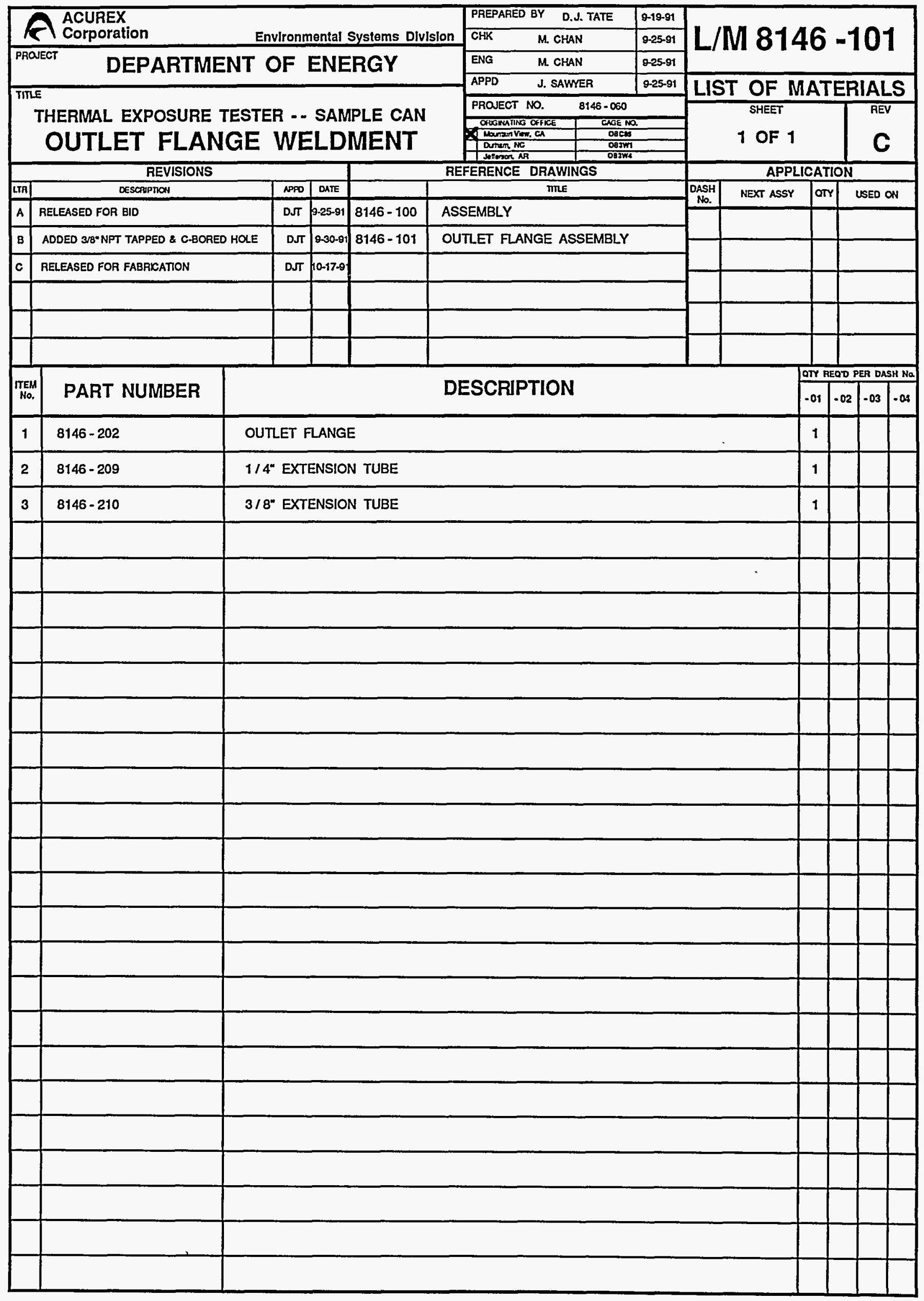




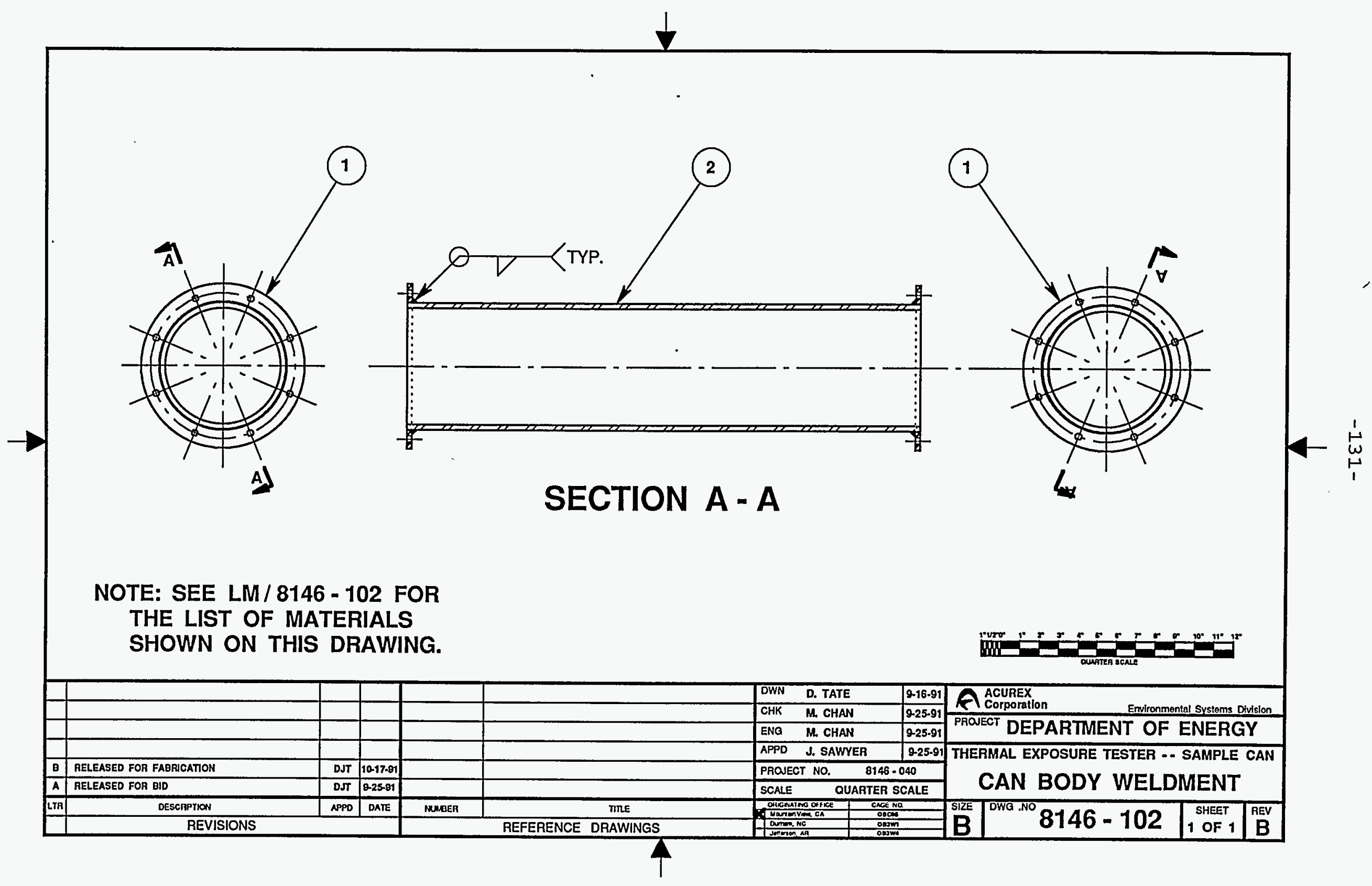




\section{$-132-$}

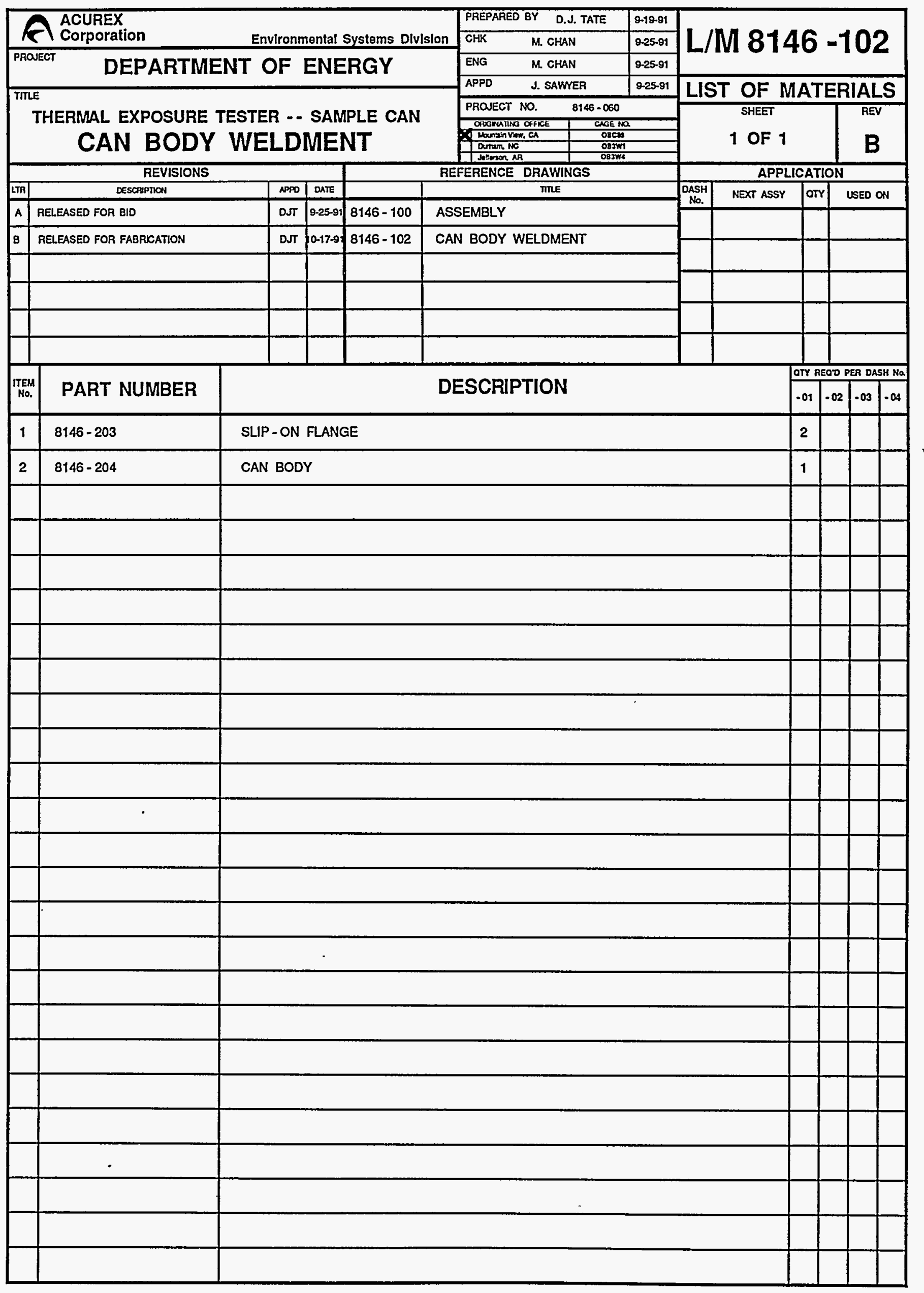




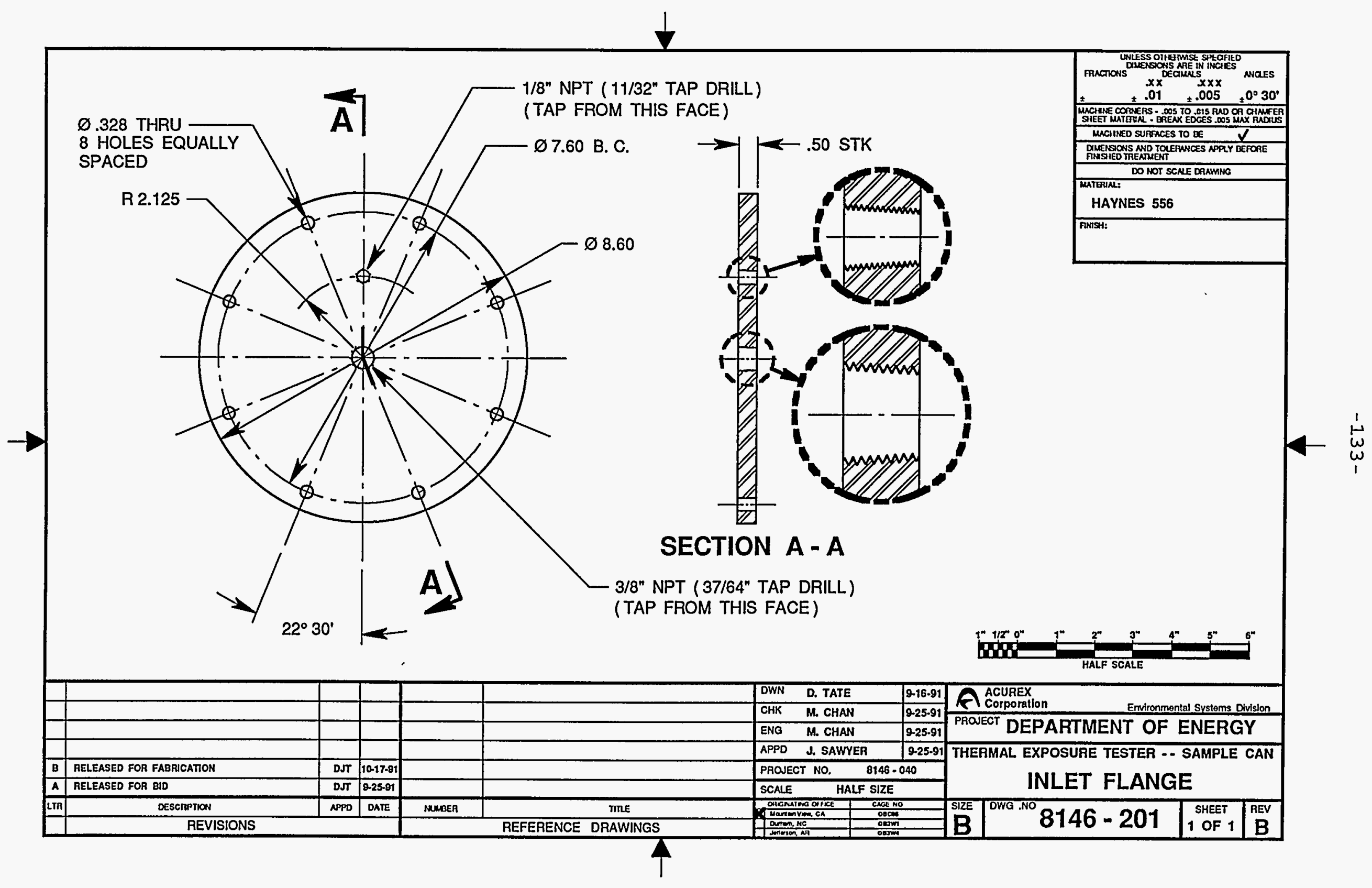




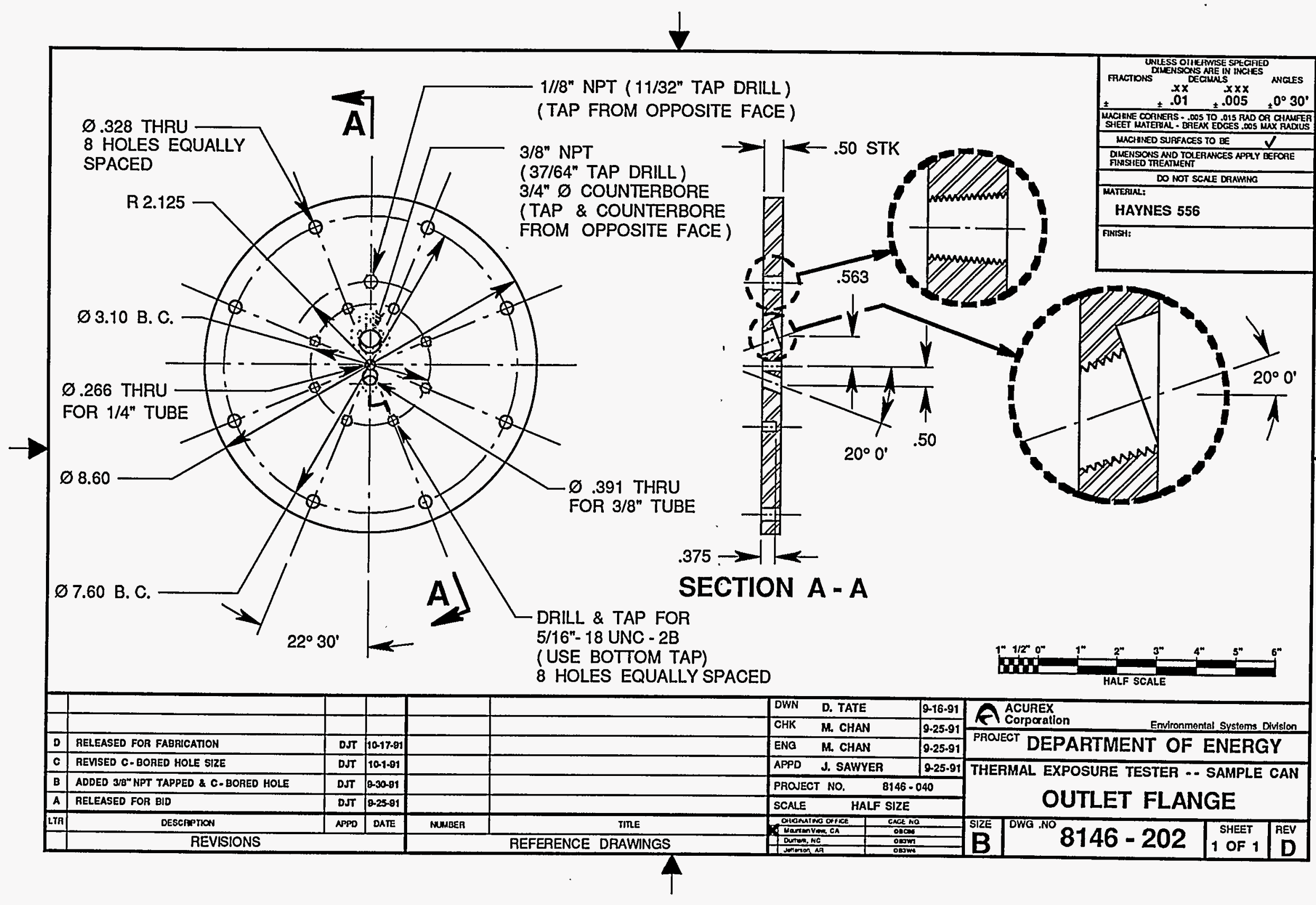




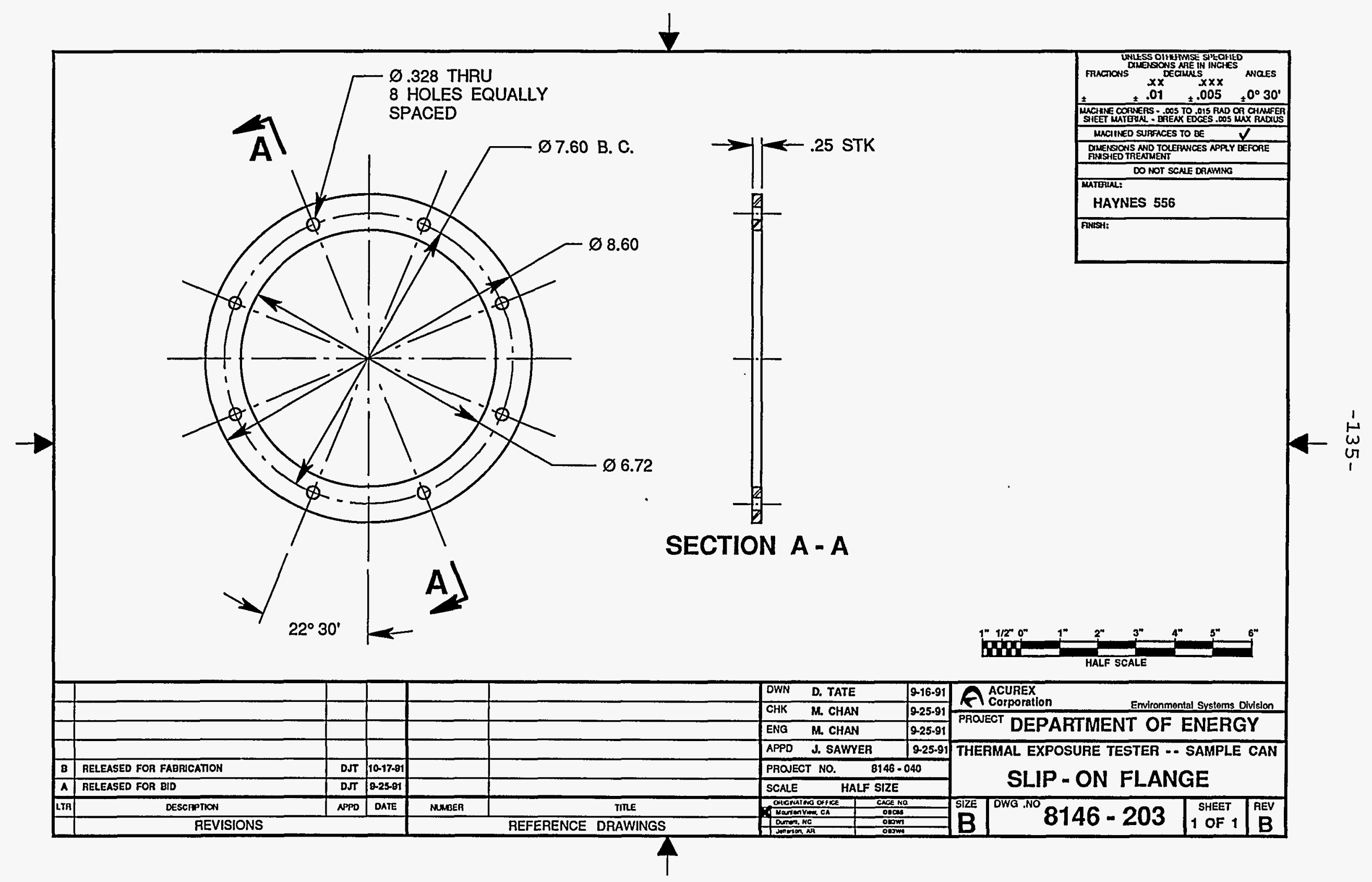




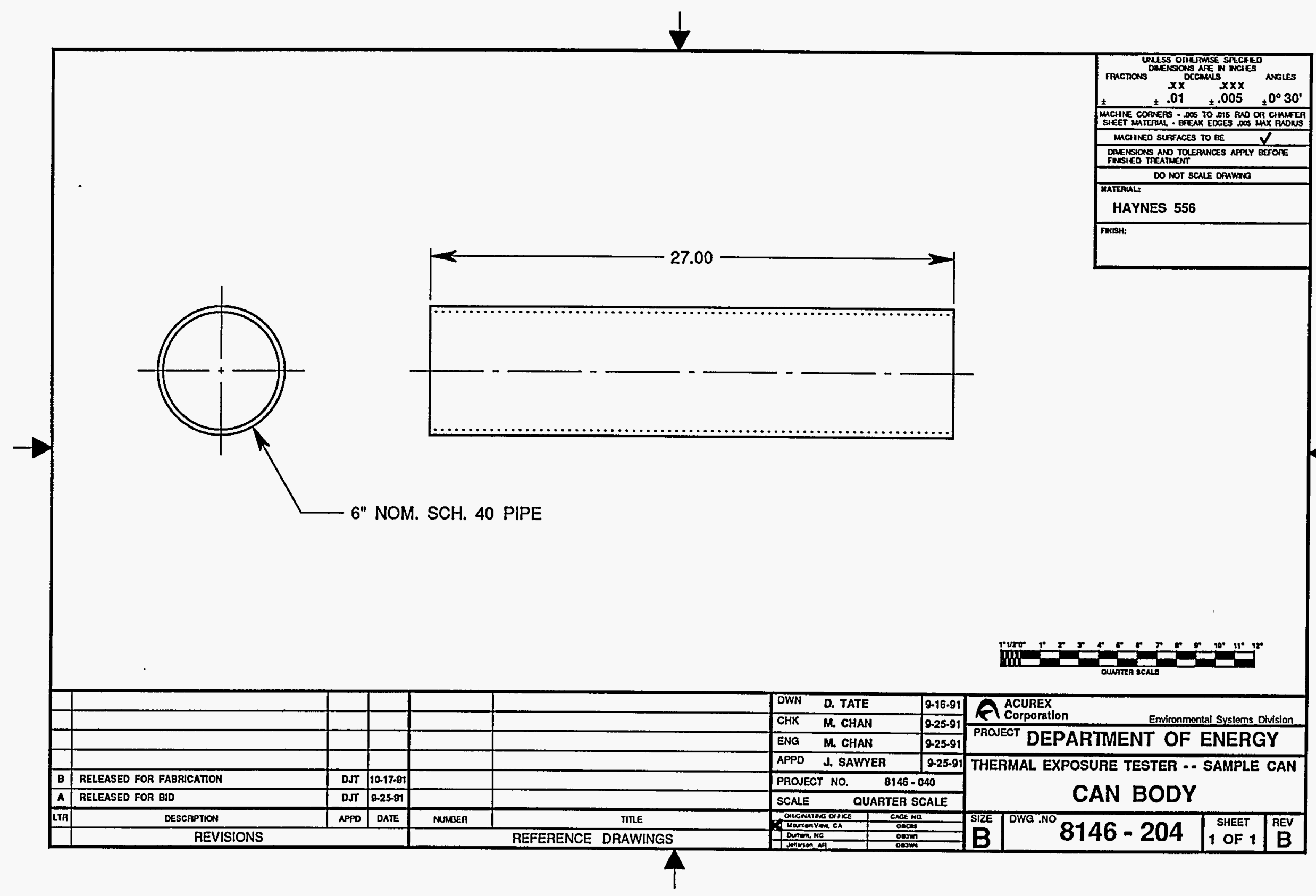




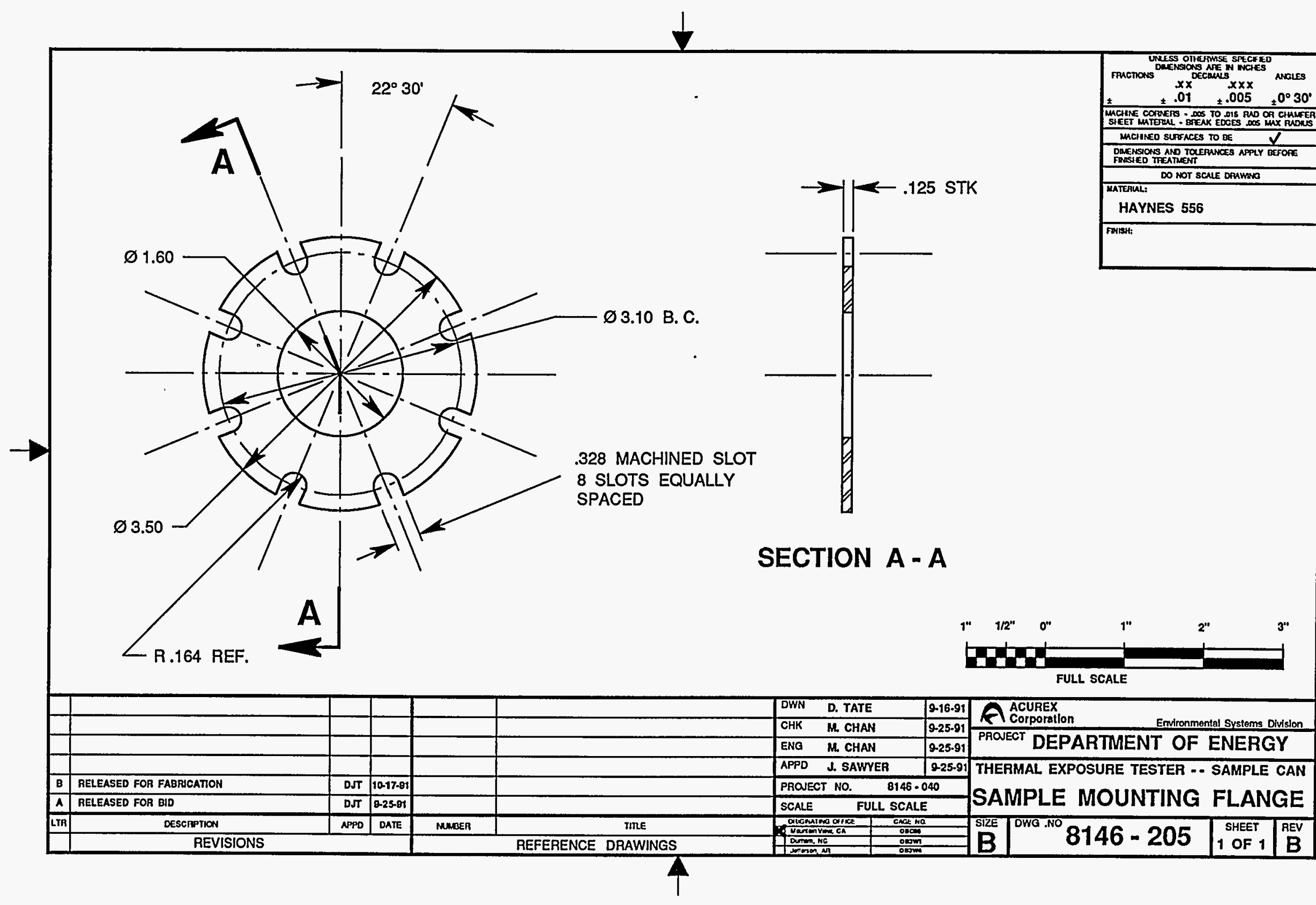




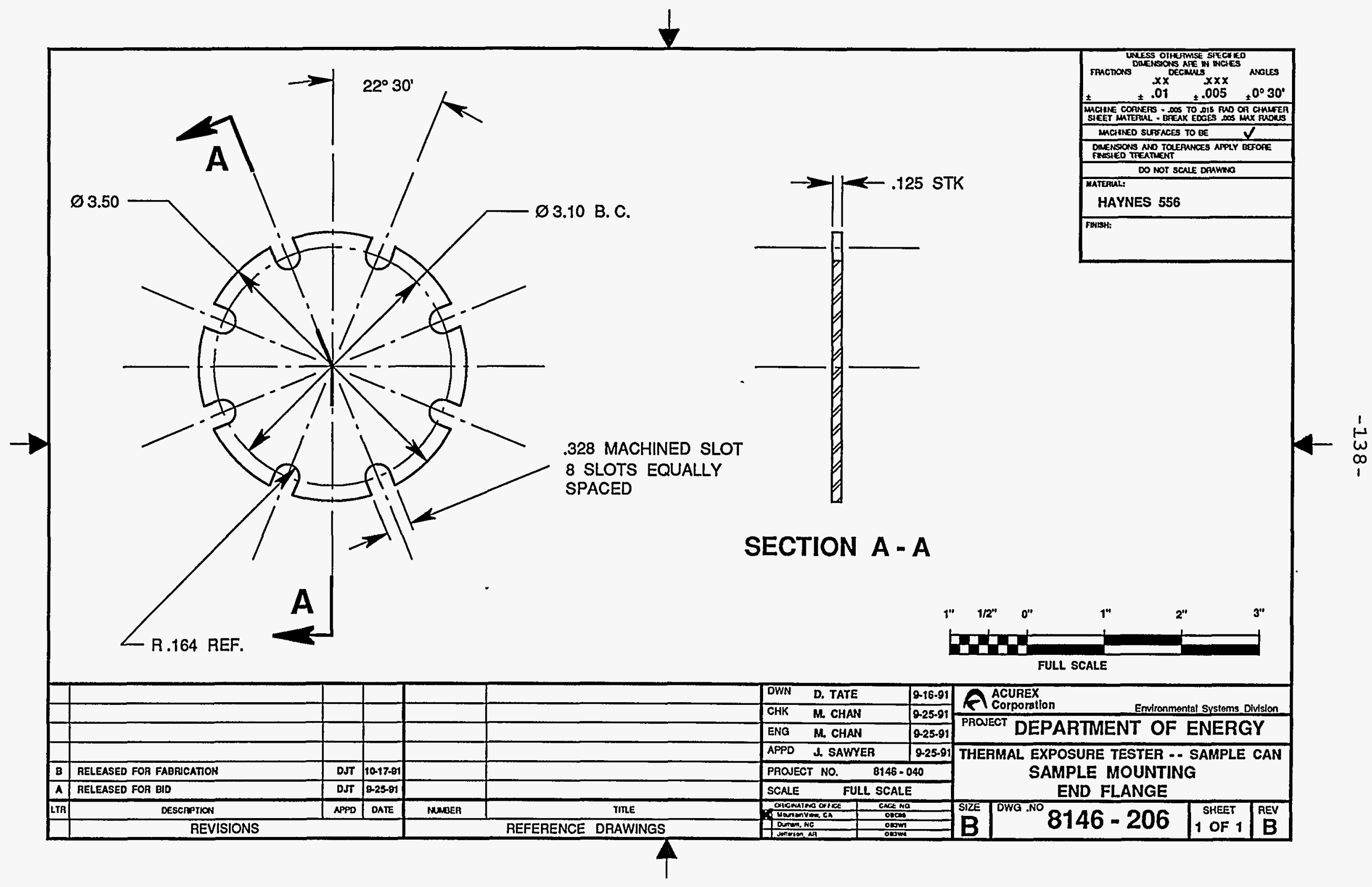




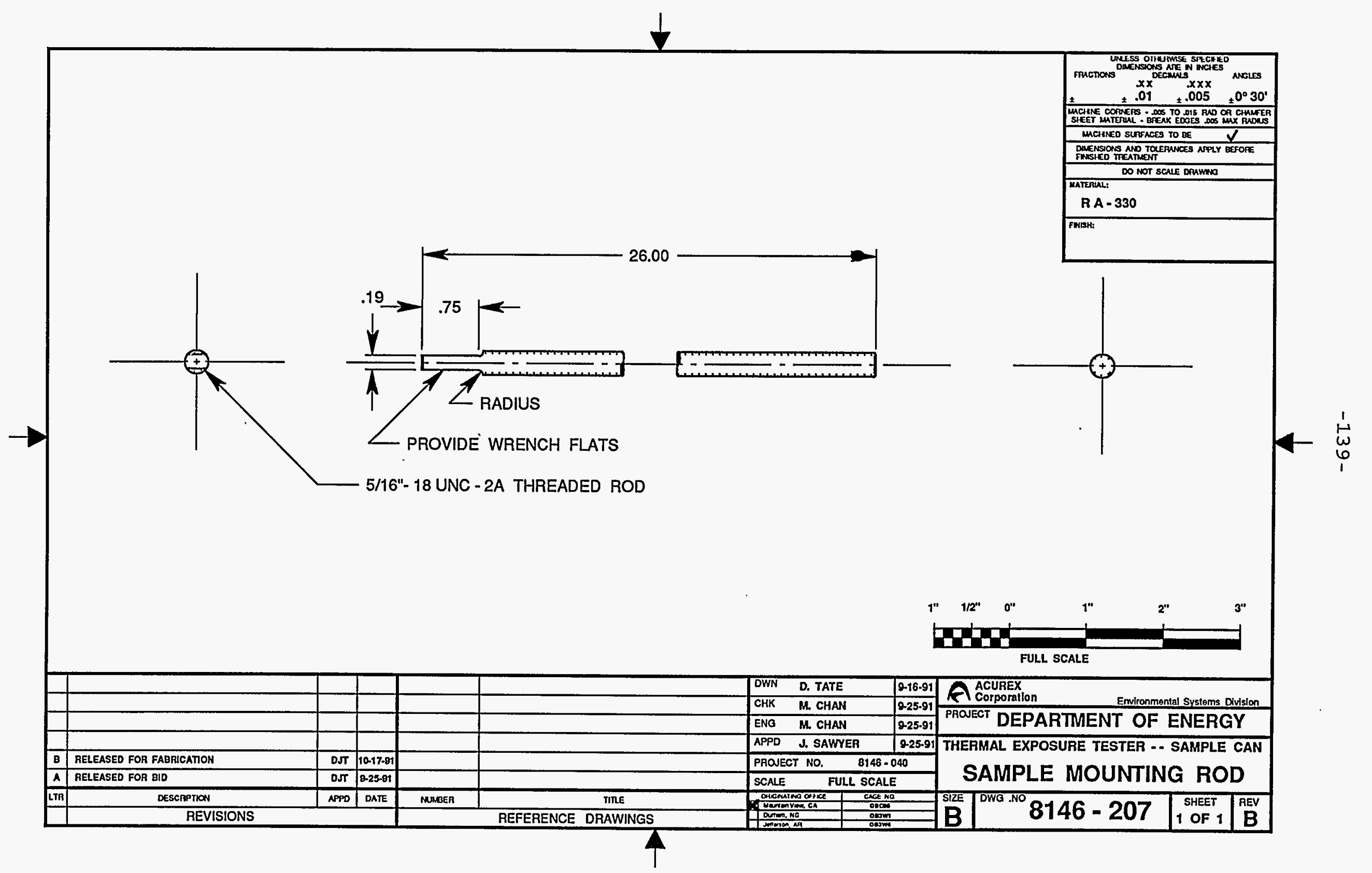




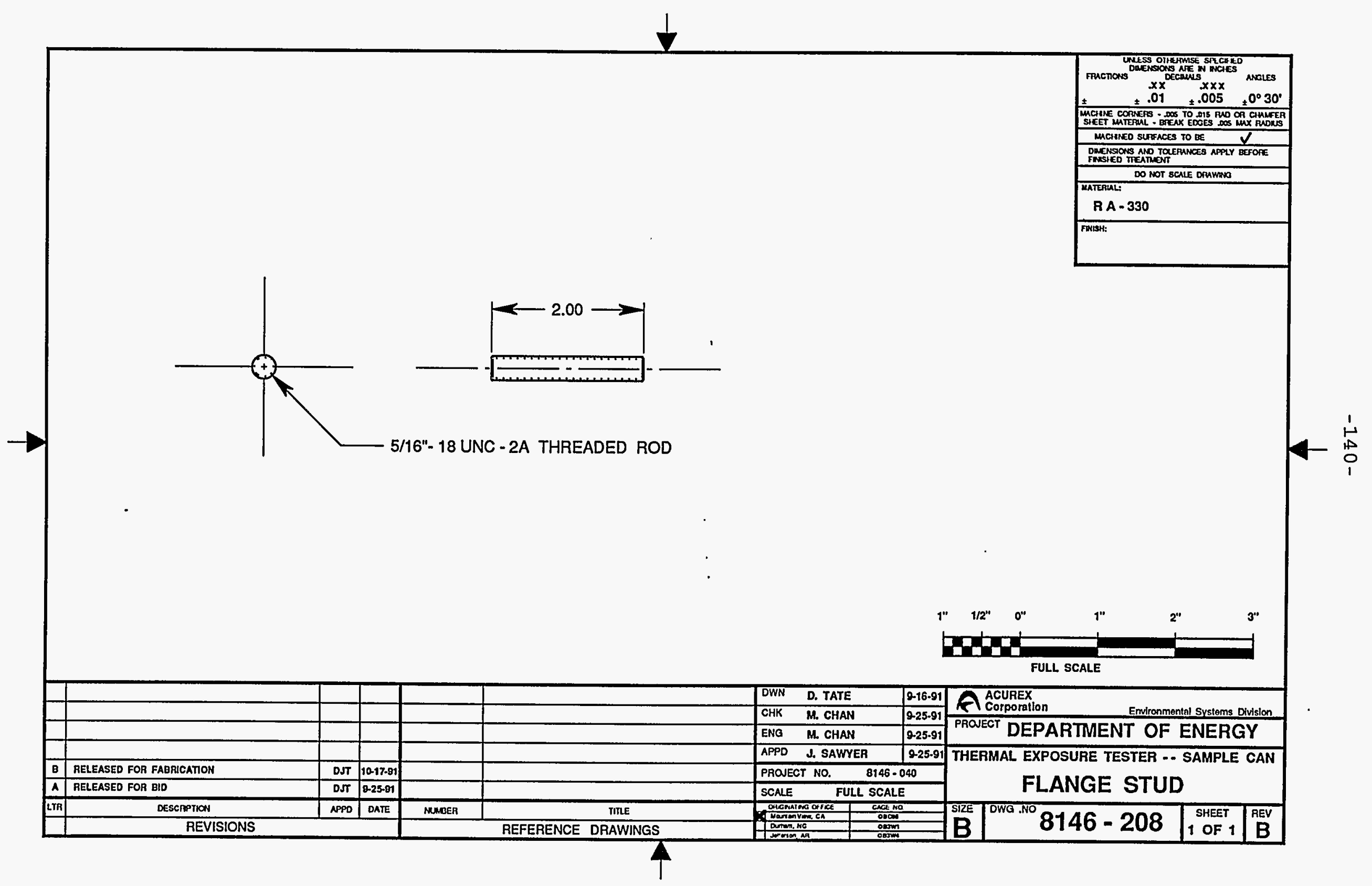




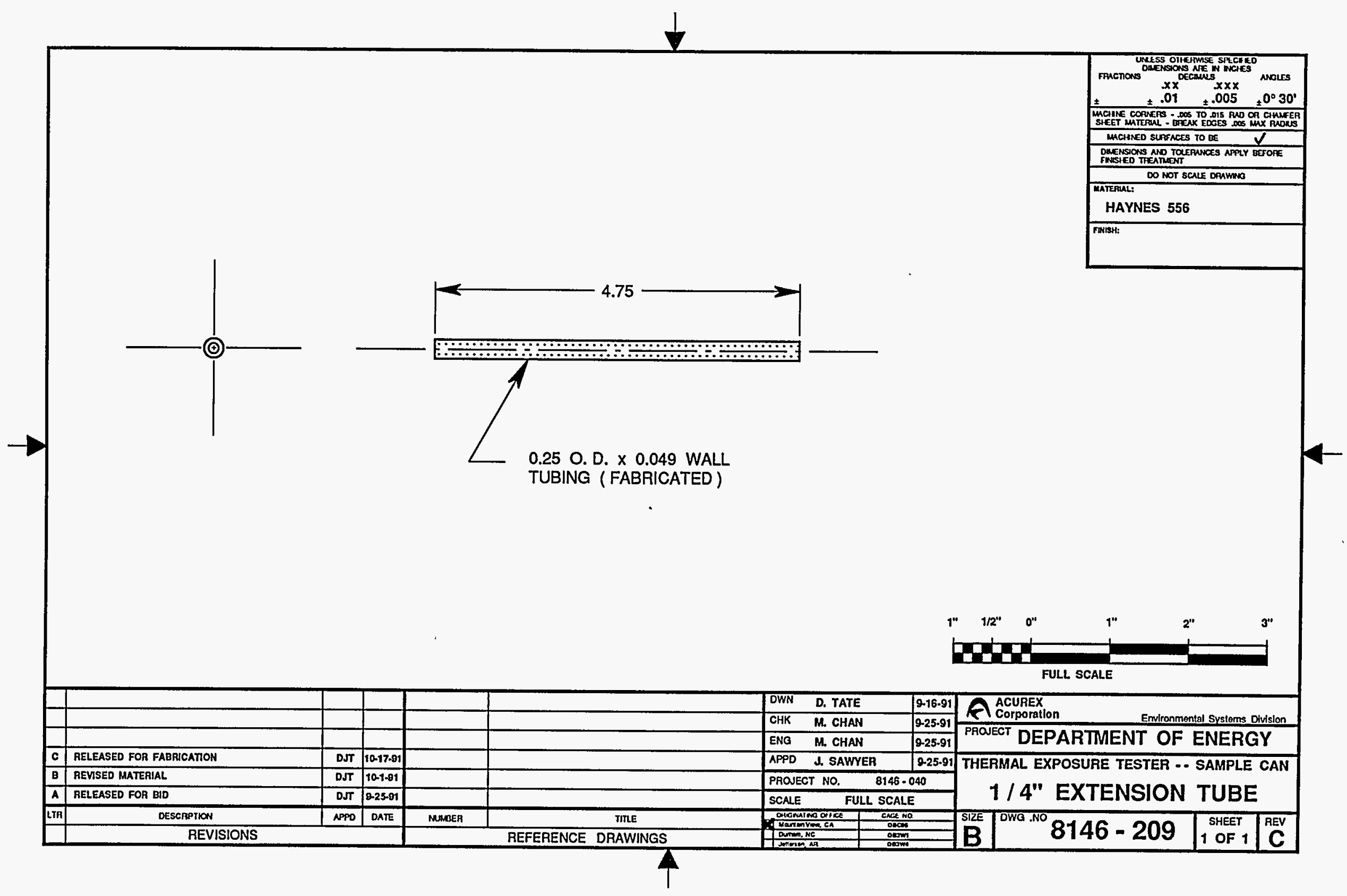




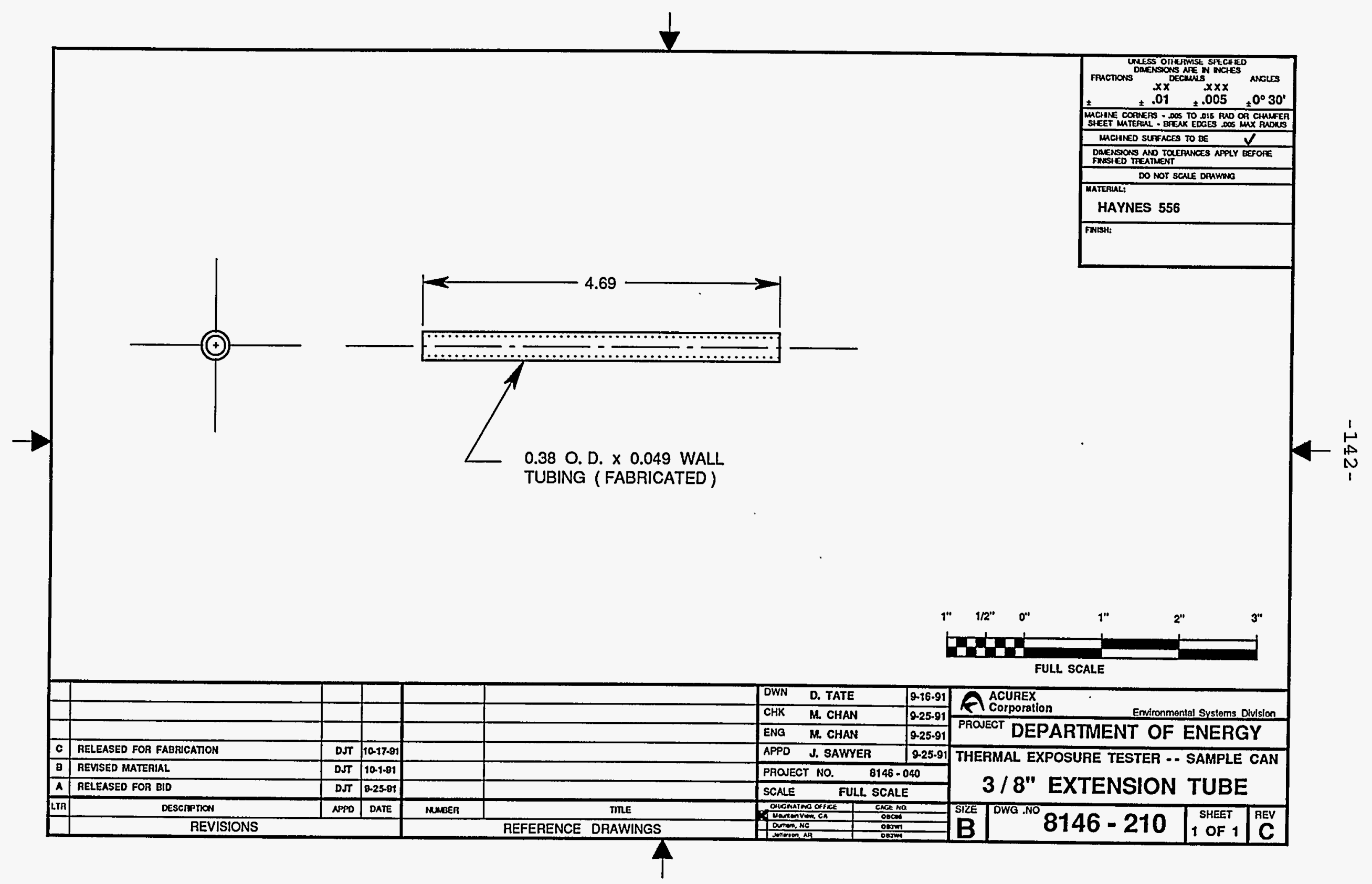


APPENDIX C

REPORT: "THERMAL SHOCK-INDUCED STRENGTH DEGRADATION OF POROUS SiC CANDLE FILTERS"

Reunowe for sepente cycling. at 
$-200-$

This Page Intentionally Left Blank 


\section{APPENDIX B: SKETCHES OF CERAMIC C-RING TESTING FIXIURES}

The cost of the raw materials to make one set of fixtures out of Hexoloy SA Sic (from Carborunduma) was quoted to be about $\$ 10,300$. The cost of having the fixtures milled was not attempted because of the expensive cost of the raw materials. Ceramics are brittle materials. If a slight crack is inadvertently introduced into the fixture during manufacturing, it could causes the fixture to break. Since there would be no additional funds (nor time) to finish the Senior Project on schedule, this design route was aborted.

The following pages are preliminary sketches/designs for cring testing fixtures to be made out of a ceramic material for. elevated temperature testing. They would exceed the testing capabilities of a super alloy $\left(\approx>1200^{\circ} \mathrm{C}\right.$, low thermal expansions, and high modulus).

- Carborundum Company of Niagara Falls, New York 

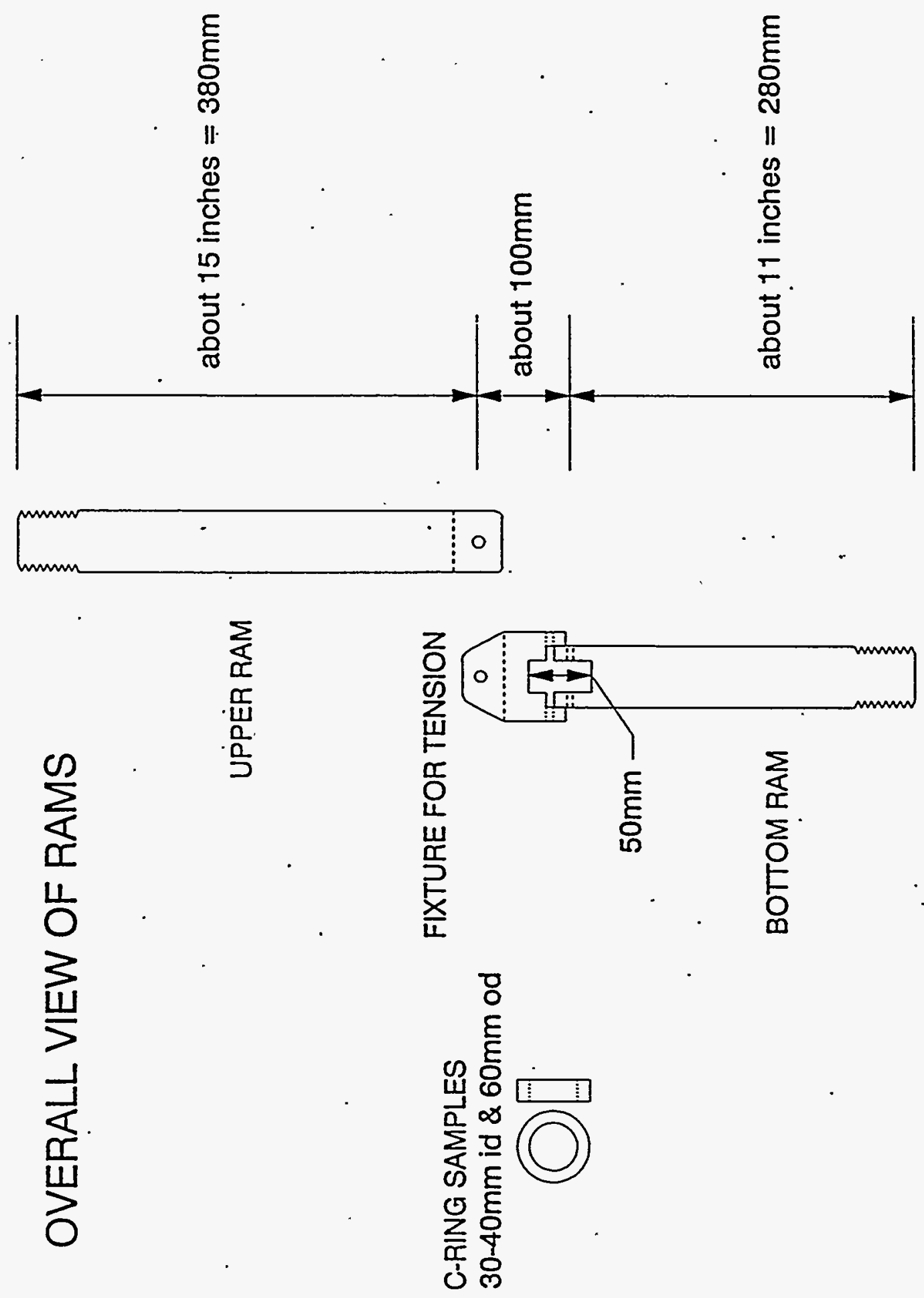

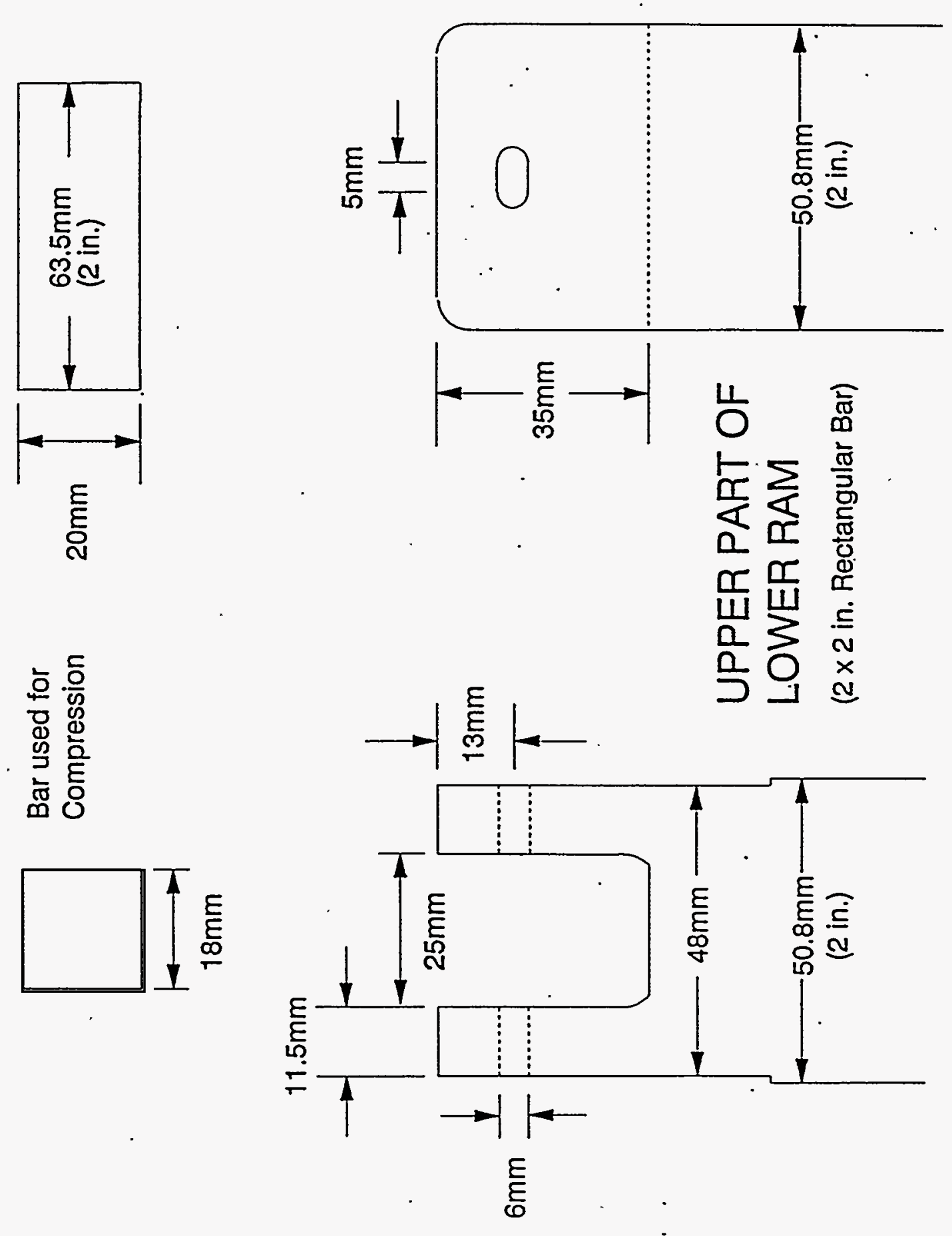

B -3 
$-204-$
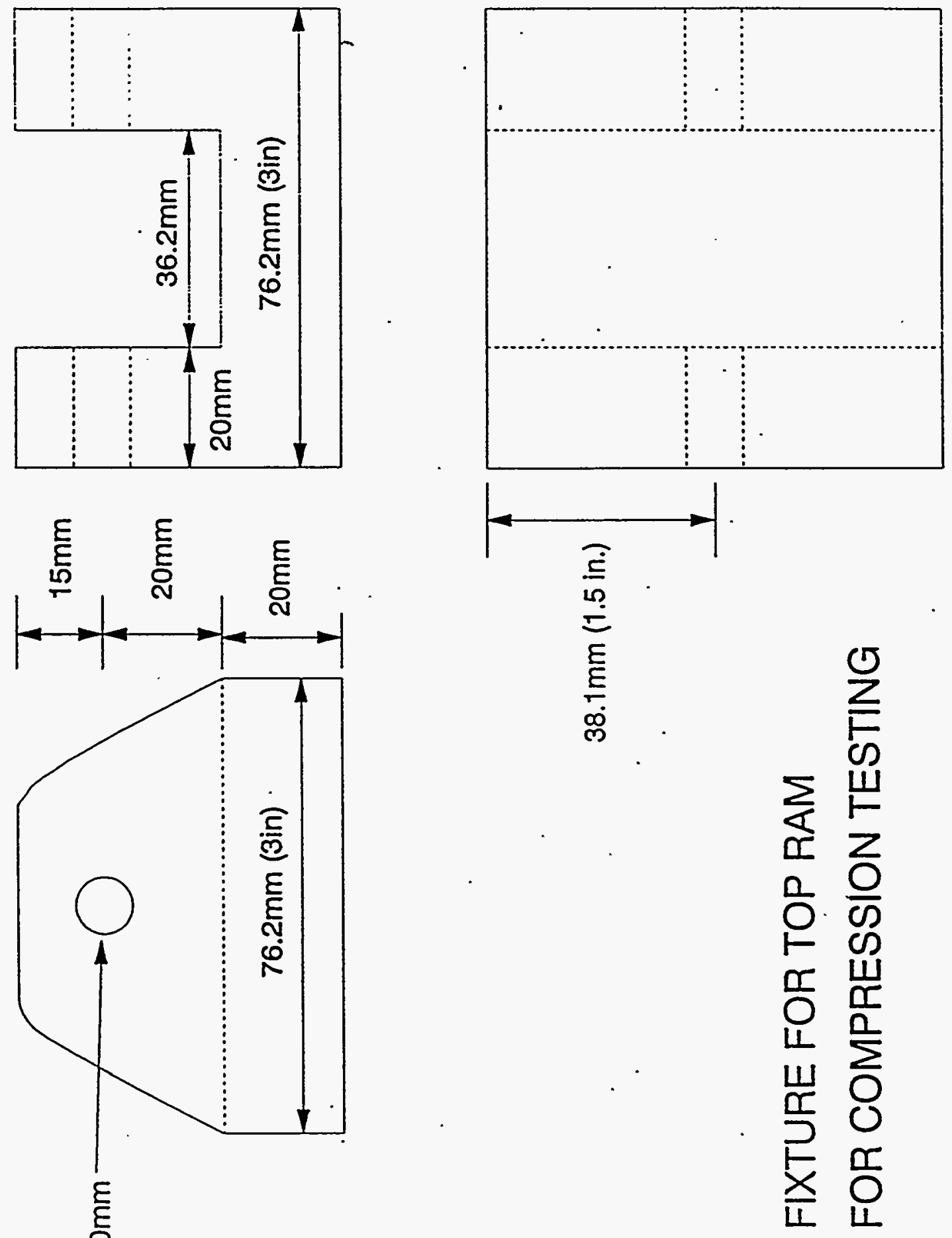

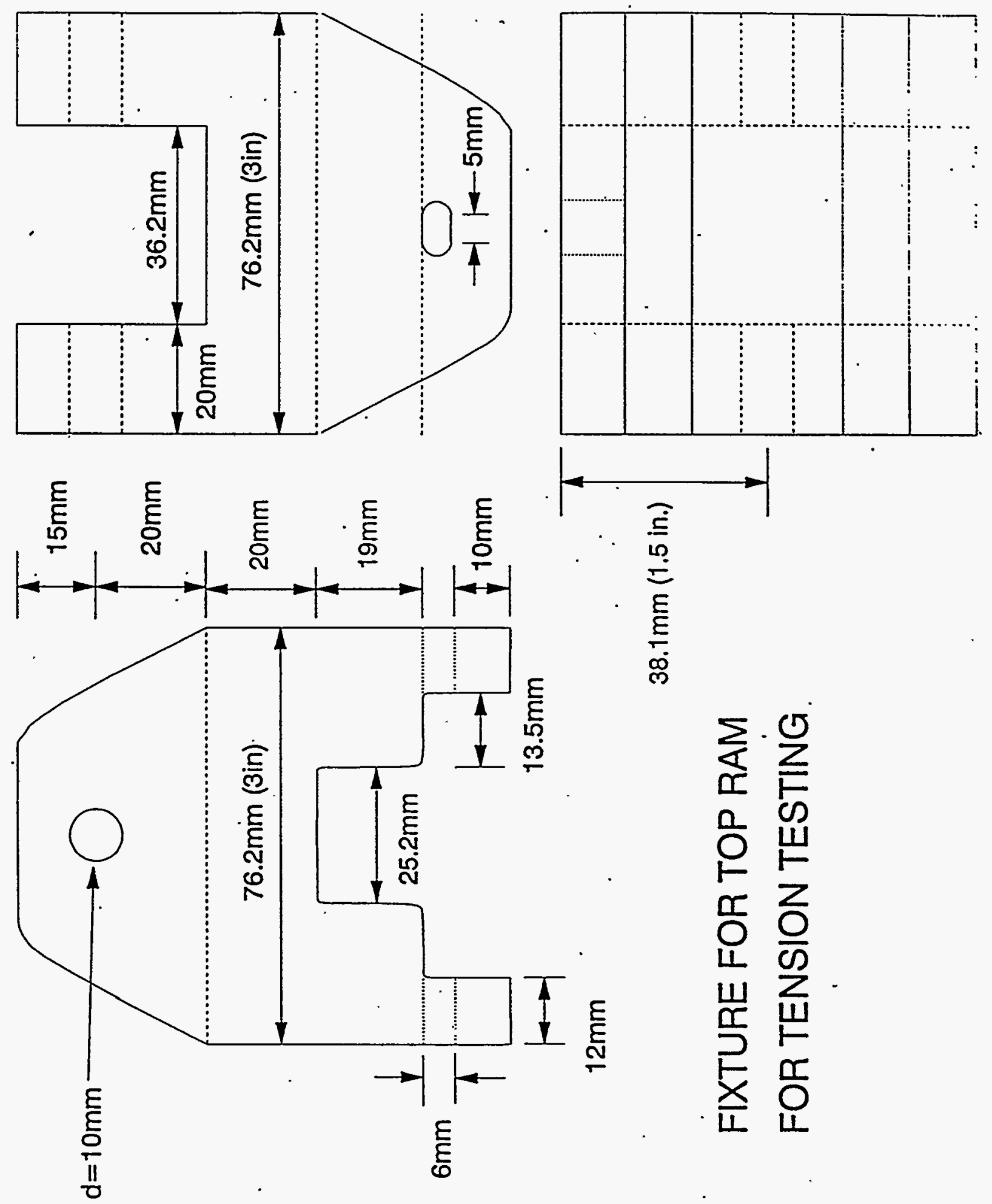

$B-5$ 

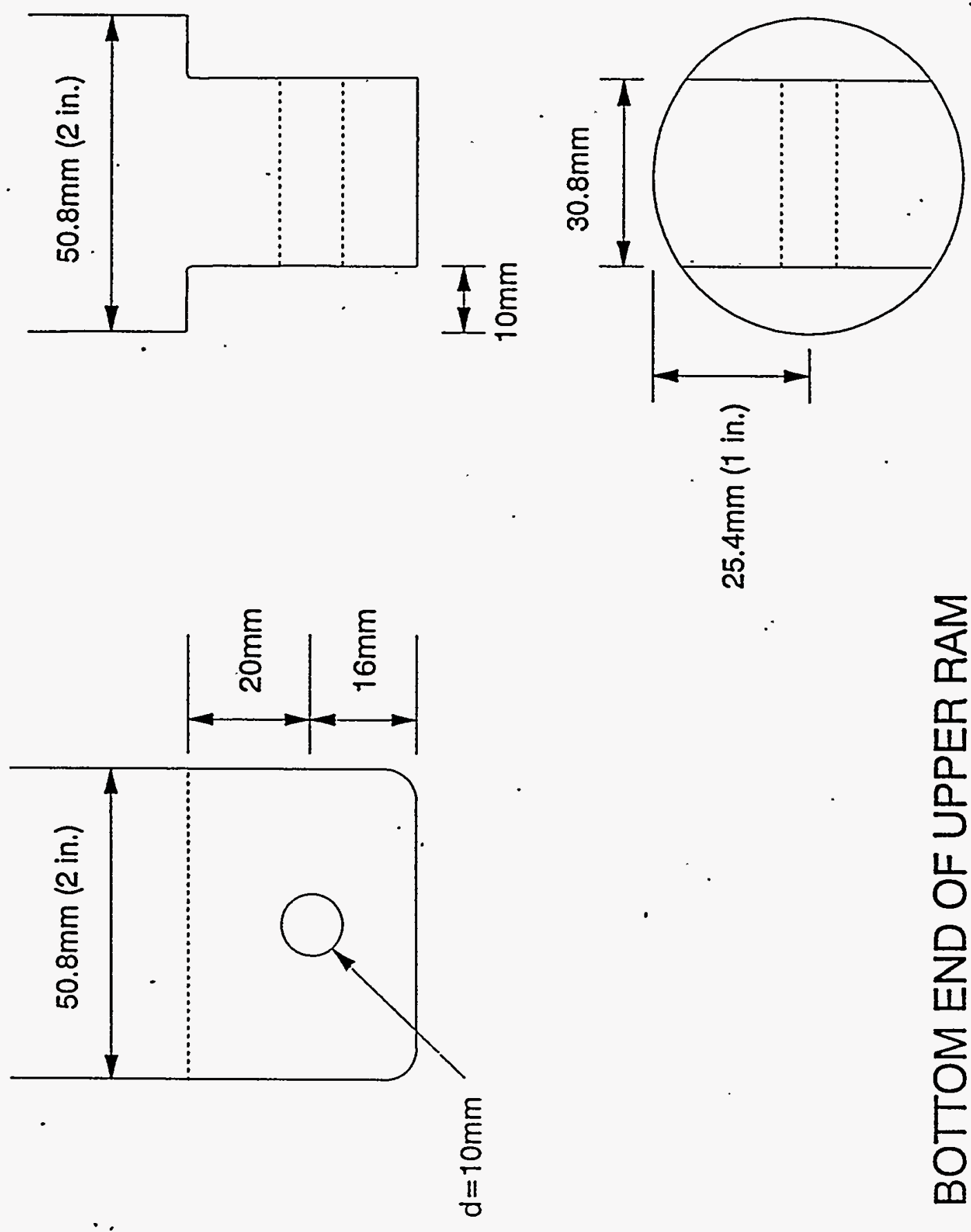

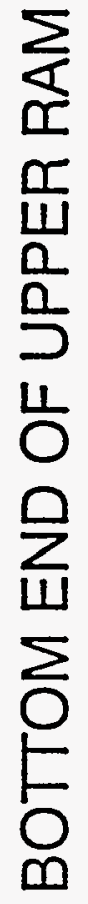

$$
\text { B- } 6
$$



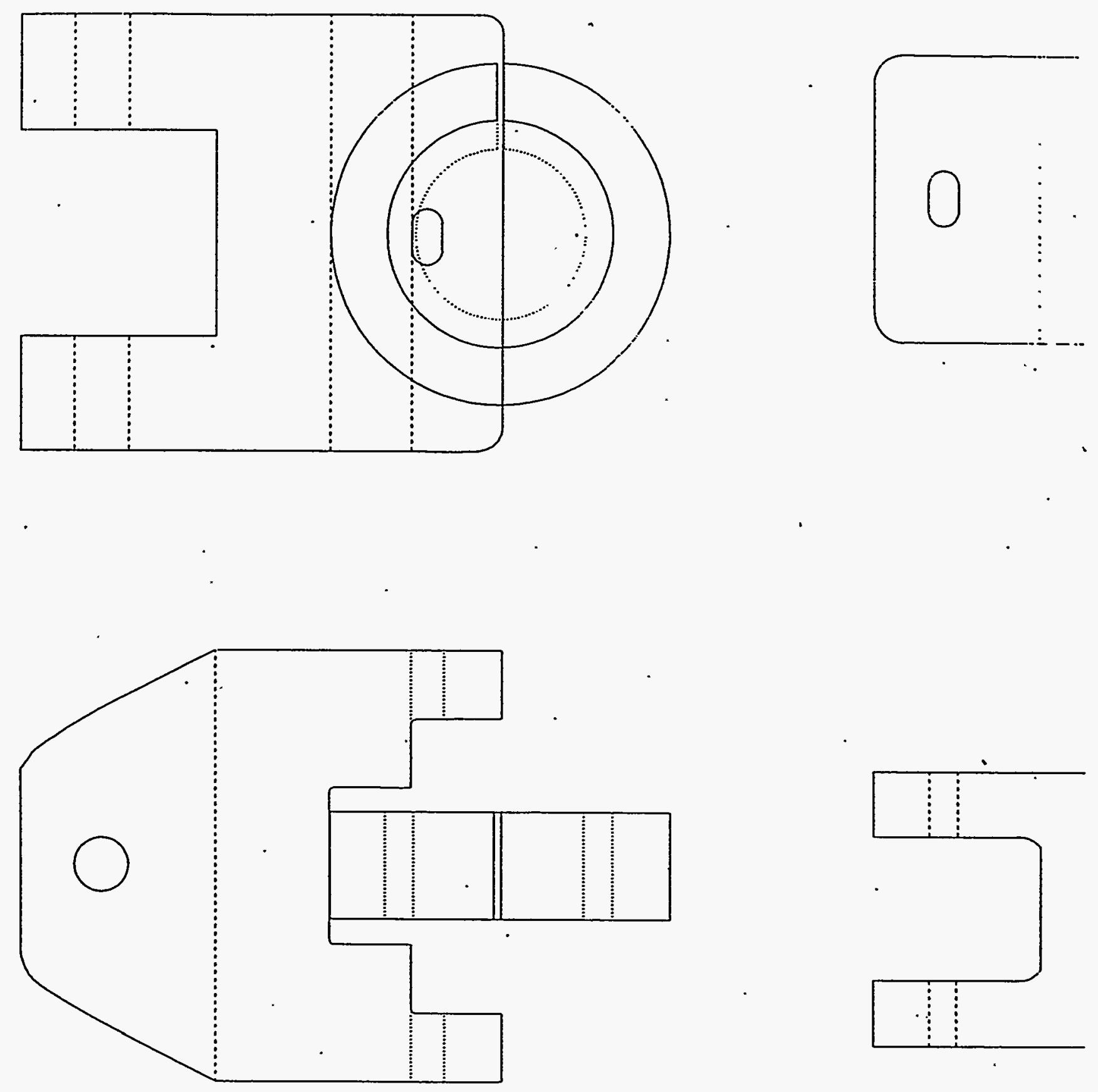

$$
\text { B-7 }
$$



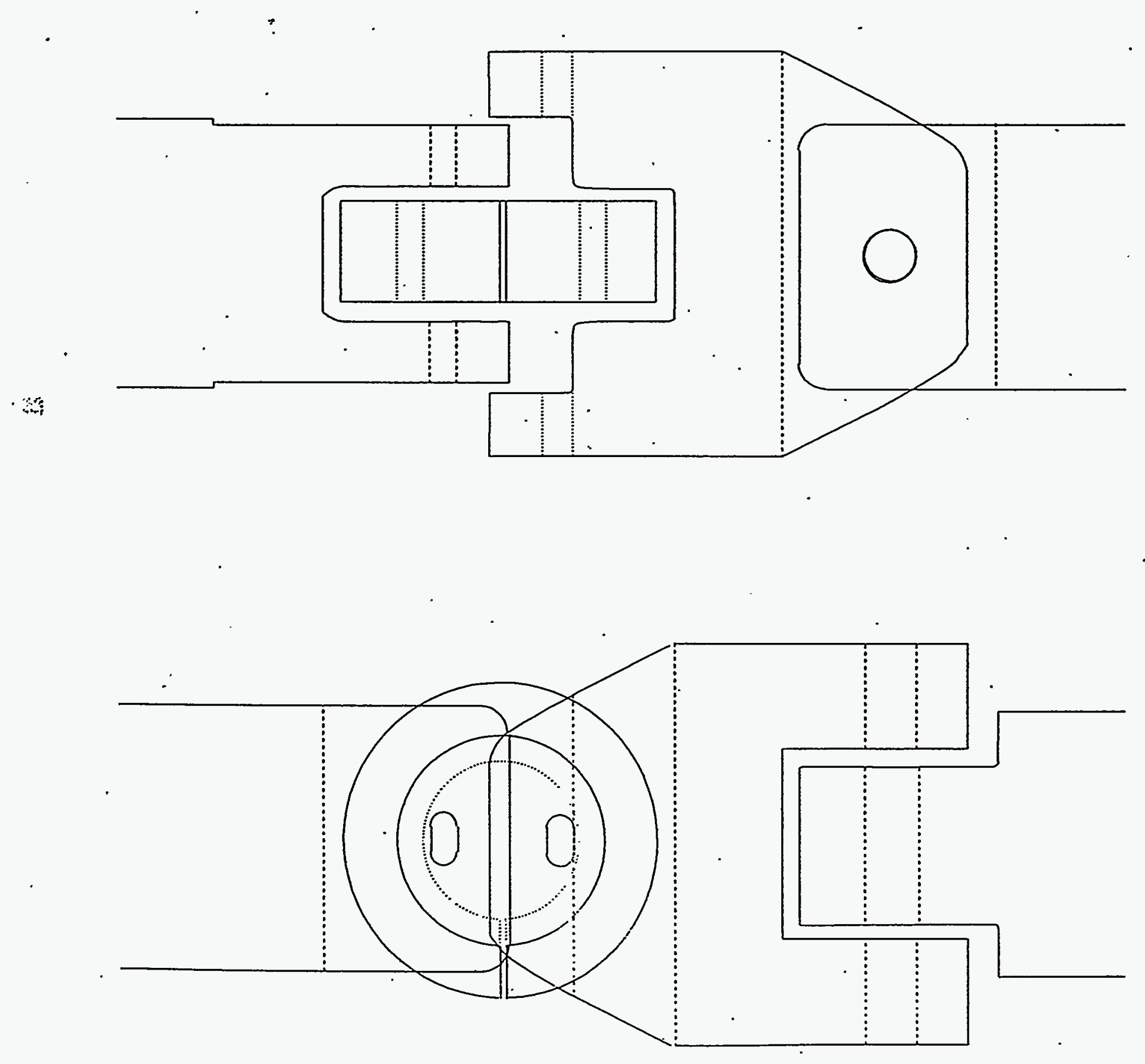

$B-8$ 

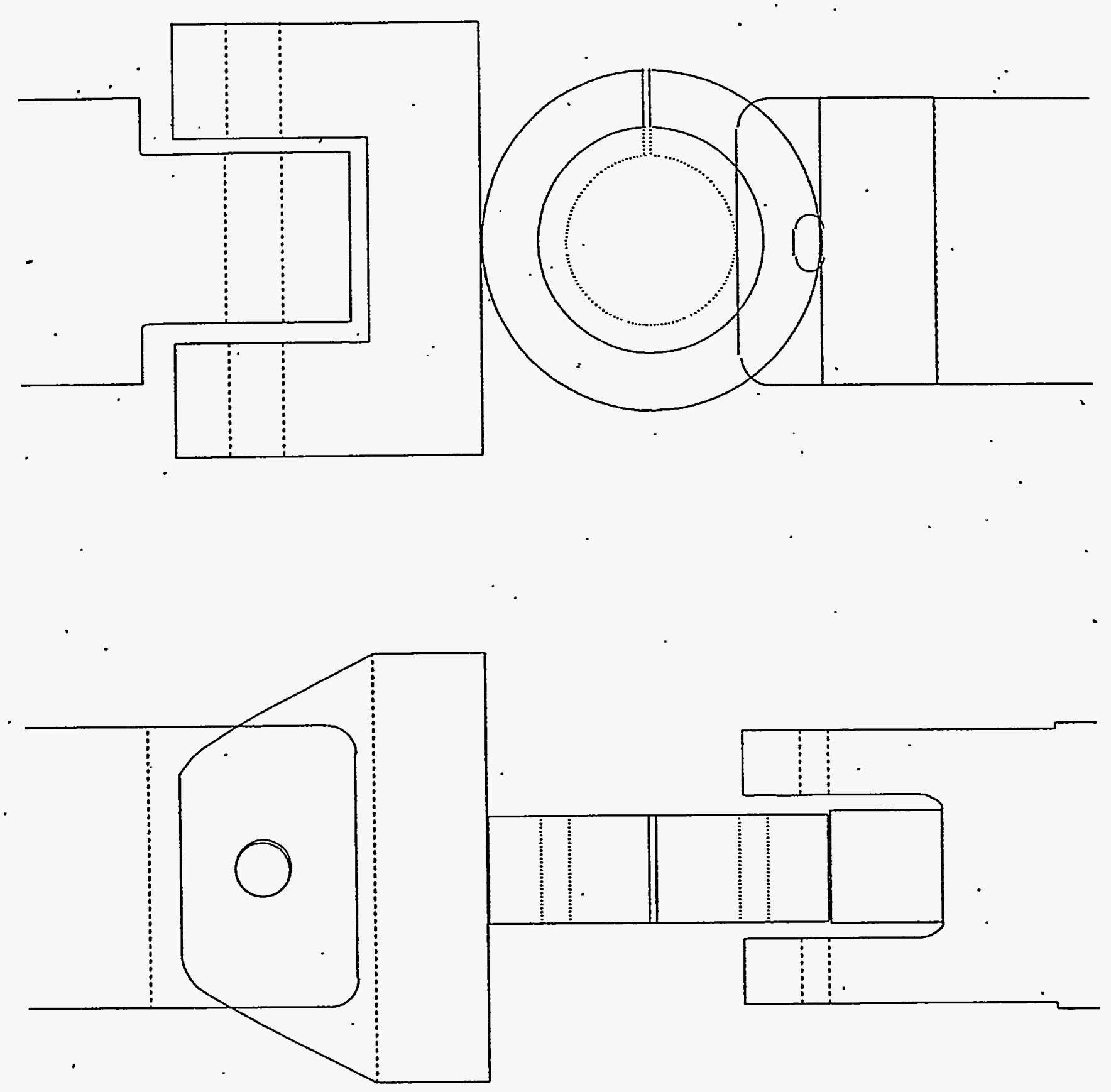

B-9 
$-210-$

This Page Intentionally Left Blank 
APPENDIX C: DESIGNS OF THE SUPERALLOY C-RING TESTING FIXTURES

The following designs were drawn by the author and submitted to Modern Machine (in San Jose) to be fabricated from Haynes ${ }^{\circledR}$ Alloy 230 (a nickel-chromium-tungsten-molybdenum alloy). The adapter/cooling couples were made of standard stainless steel that Modern Machine supplied. 


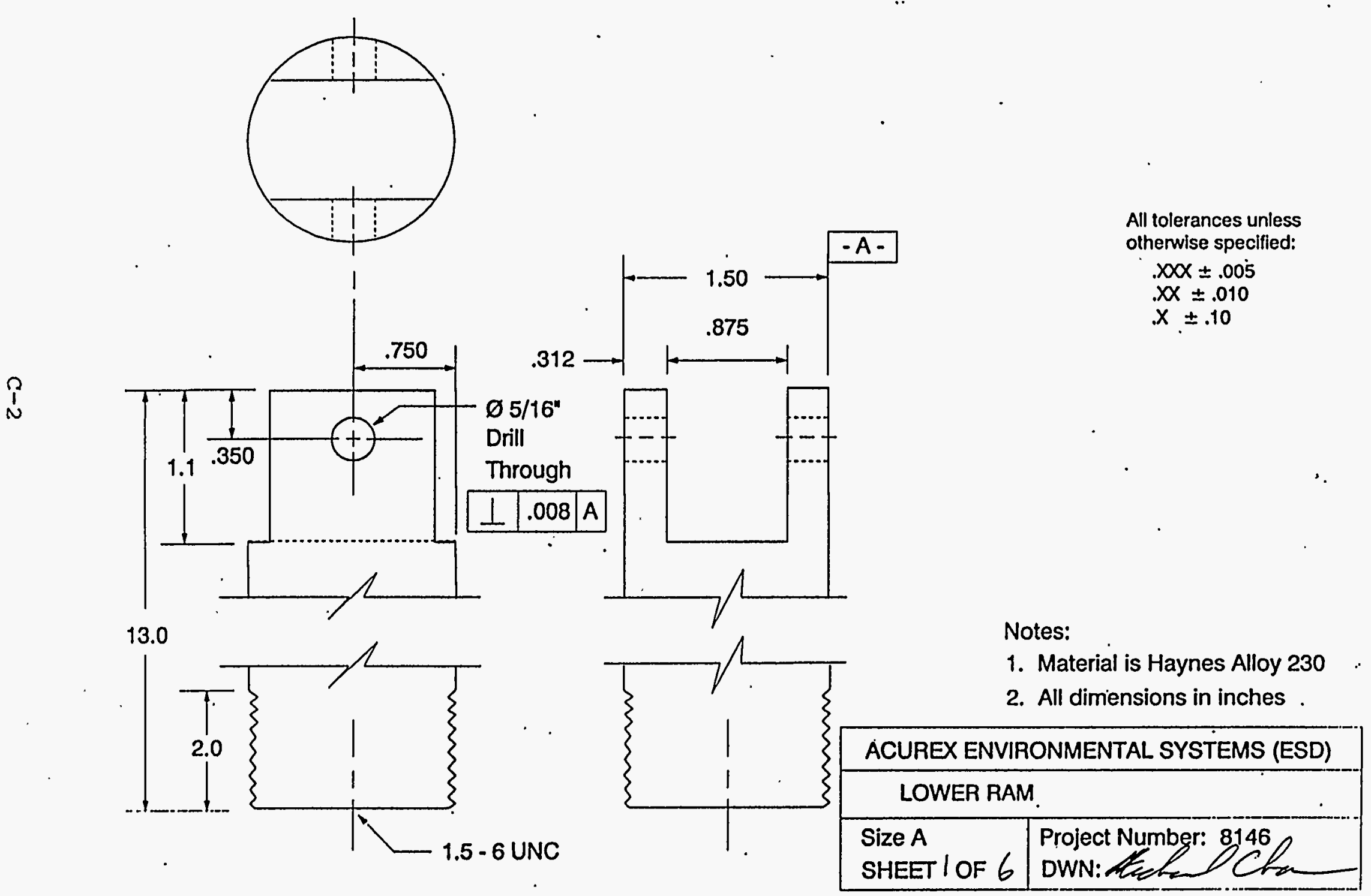




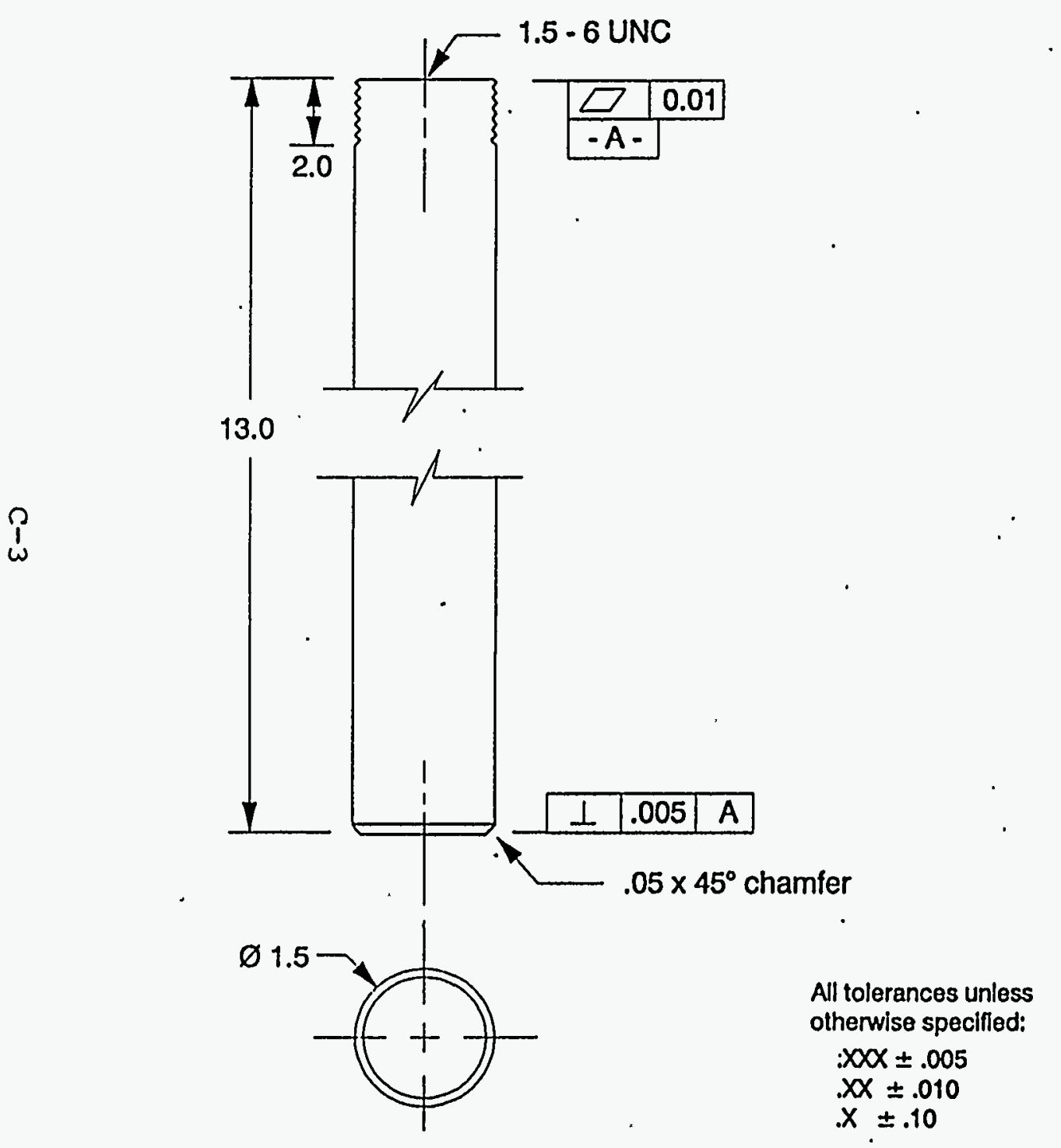

Notes:

1. Material is Haynes Alloy 230

2. All dimensions in inches

\begin{tabular}{|l|l|}
\hline \multicolumn{2}{|l|}{ ACUREX ENVIRONMENTAL SYSTEMS (ESD) } \\
\hline \multicolumn{2}{|c|}{ UPPER RAM FOR COMPRESSION TEST } \\
\hline $\begin{array}{l}\text { Size A } \\
\text { SHEET 2OF } 6\end{array}$ & Project Number: 8146 \\
\hline
\end{tabular}




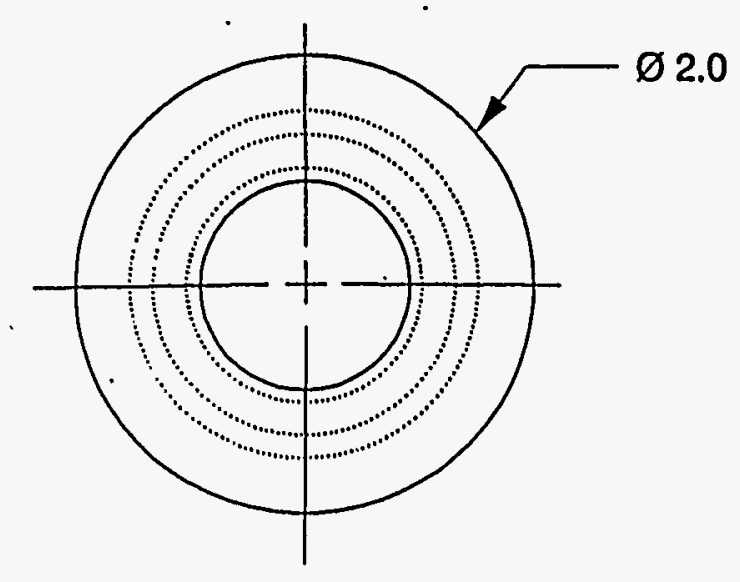

\section{All tolerances unless} otherwise specified:

$.00 X \pm .005$

$X X \pm .010$

$x \pm .10$

Notes:

1. Material is

2. All dimensions in inches

3. Quantity required is 2

\begin{tabular}{|l|l|}
\hline \multicolumn{2}{|l|}{ ACUREX ENVIRONMENTAL SYSTEMS (ESD) } \\
\hline \multicolumn{2}{|c|}{ ADAPTER COUPLE FOR UPPER RAM (COMPR.) } \\
\hline Size A & Project Number: 8146 \\
SHEET 3OF 6 & DWN: tyefud Che \\
\hline
\end{tabular}




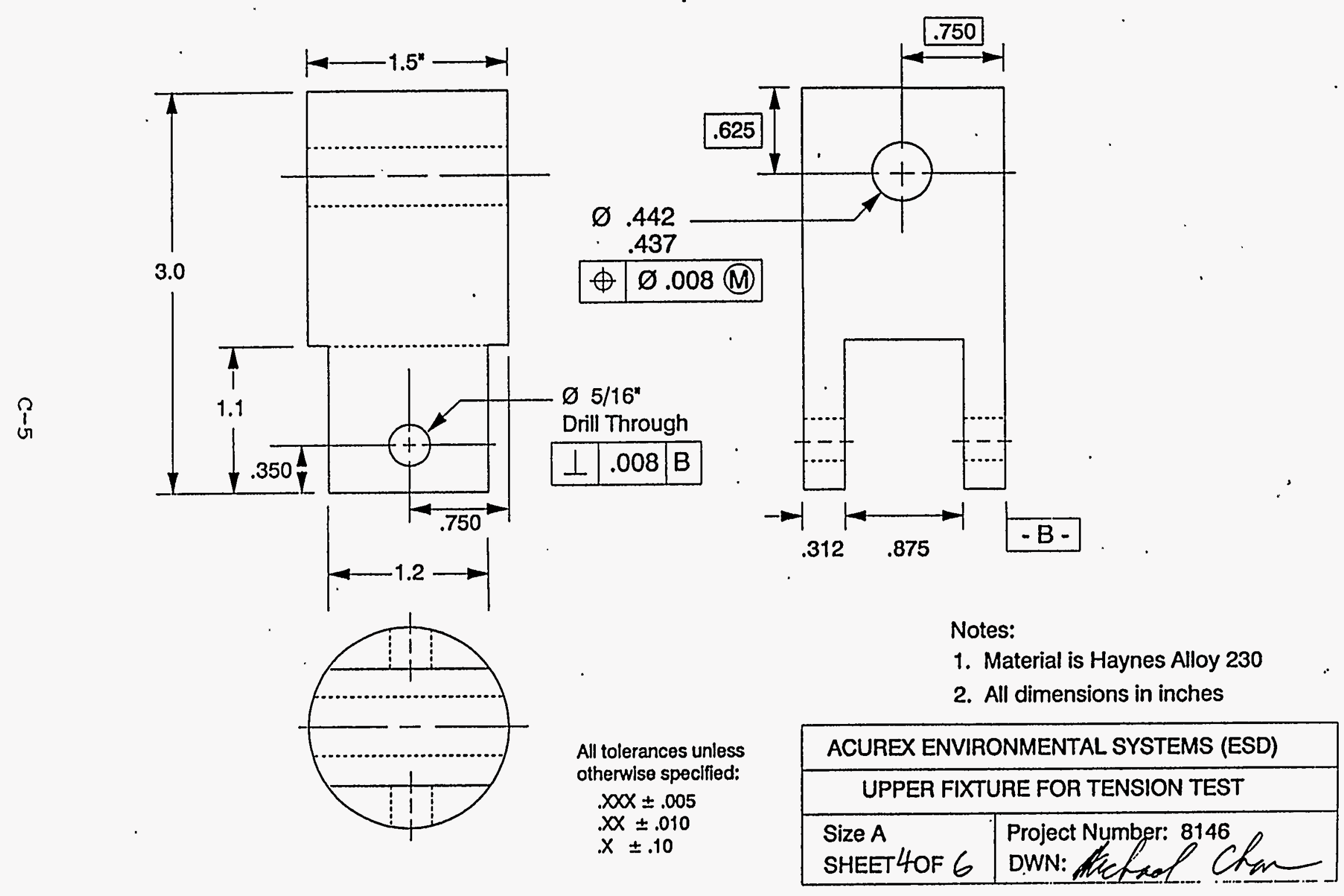




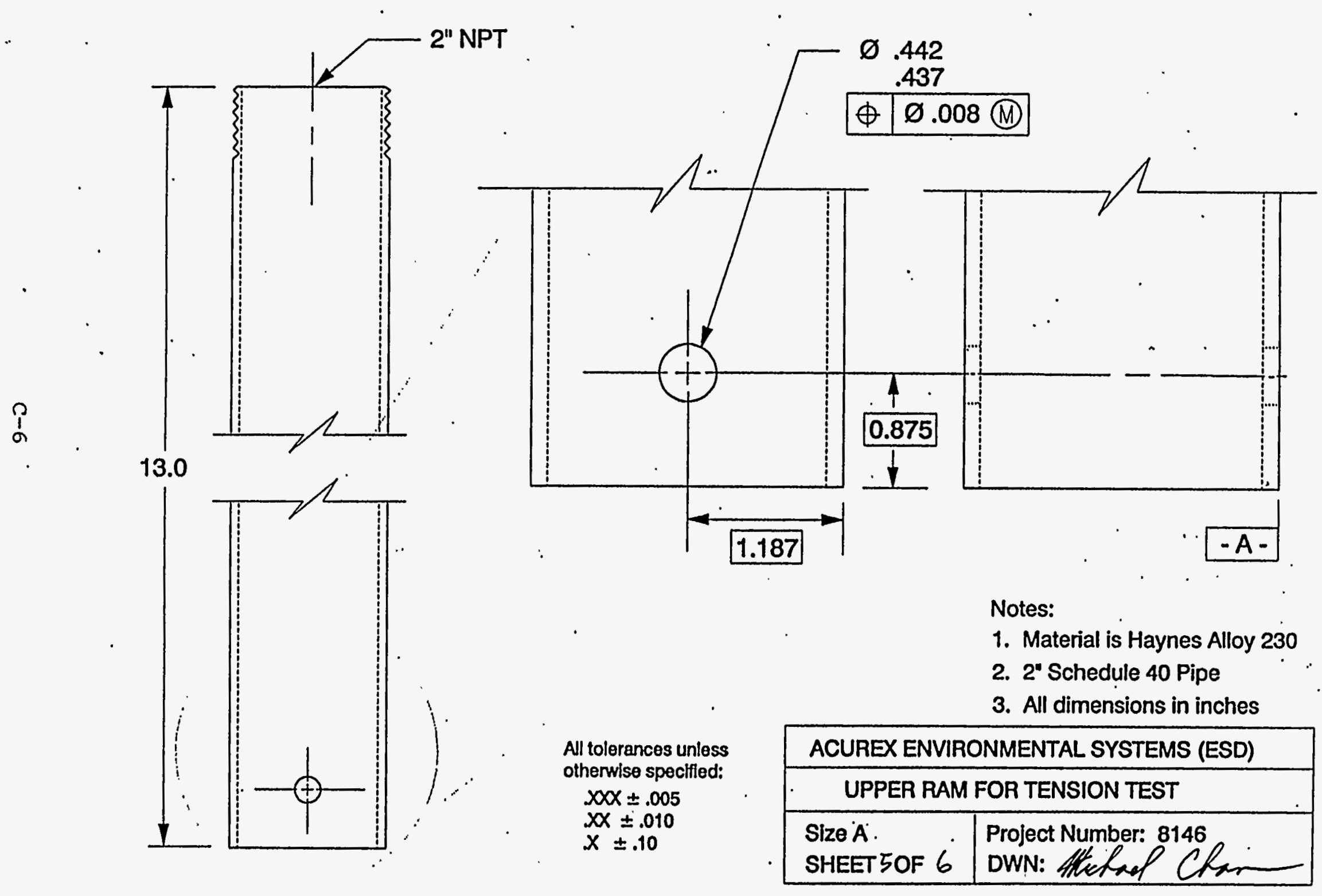




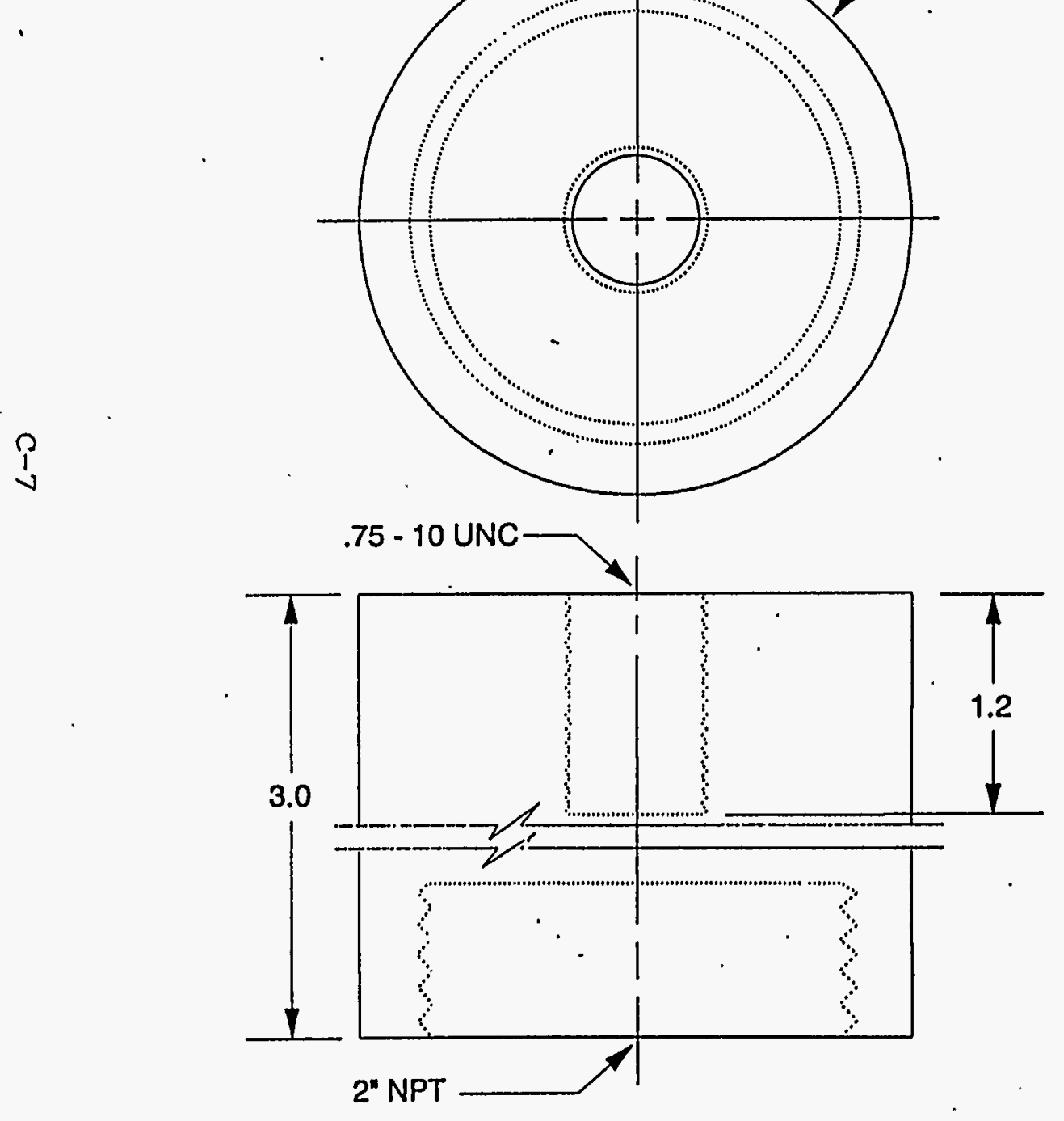

All tolerances unless otherwlse specified: $. X X X \pm .005$ $. X X \pm .010$ $x \pm .10$

Notes:

1. Material is

2. Female 2" NPT for a 2 " Schedule 40 Pipe .

3. All dimensions in inches

- ACUREX ENVIRONMENTAL SYSTEMS (ESD) ADAPTER COUPLE FOR UPPER RAM (TENSION) 
This Page Intentionally Left Blank 
APPENDIX D: RAW DATA AND MAXIMUM STRESS CALCULATIONS

The equation used for calculating the maximum stresses for cring compression and tension testing is:a

$$
\sigma_{\theta}=\frac{P}{W\left(I_{0}-I_{i}\right)}\left[\frac{\frac{I_{0}-I_{i}}{\ln \left(\frac{I_{0}}{I_{i}}\right)}\left(I-\frac{I_{0}+I_{i}}{2}\right)}{I\left[\frac{I_{0}-I_{i}}{\ln \left(\frac{I_{0}}{I_{i}}\right)}-\frac{I_{0}+r_{i}}{2}\right]}\right] \cos \theta
$$

Note: $\cos \theta=1$ for $\theta=0^{\circ}$

$\mathrm{P}=$ breaking load (negative for compressive loading)

$\mathrm{w}=\mathrm{c}-\mathrm{ring}$ thickness

$r=$ radial distance of interest

$r_{1}=$ inner radius.

$r_{0}=$ outer radius

The following pages are the raw data and stress calculation spreadsheets in Lotus 1-2-3. Two inner diameter (I.D.) (as well as two outer diameter) measurements were made and averaged. The averaged value was then corrected because the calipers the author used was not calibrated.

a Ferber, M. K., V. J. Tennery, S. B. Waters, and J. Ogle, "Fracture Strength Characterization of Tubular Ceramic Materials Using a Simple C-ring Geometry", Journal of Materials Science, $V$. 21, 1986, pp. 2628-2632 
$05 / 20 / 91$

CORRECTED CORRECTED

SPECIMEN SPECIHEN I.D. 1 I.D. 2 O.D. 1 O.D. 2 AVE. I.D. I.D. AVE. 0.D. 0.D. WIDTH TEST LOAD NUKBER (in.) (in.) (in.) (in.) (in.) (in.) (in.) (in.) (in.) (lbs)

\begin{tabular}{|c|c|c|c|c|c|c|c|c|c|c|c|c|}
\hline SCEUHACHER & $\mathrm{T} 2$ & 1.220 & 1.231 & 2.390 & 2.380 & 1.226 & 1.246 & 2.385 & 2.425 & 0.775 & $\mathrm{RIT}$ & 22.75 \\
\hline SOLAR (ONOSED) & $-T 13$ & 1.190 & 1.202 & 2.386 & 2.376 & 1.196 & 1.216 & 2.381 & 2.421 & 0.770 & $\operatorname{RIT}$ & 28.25 \\
\hline & T17 & 1.185 & 1.190 & 2.378 & 2.364 & 1.188 & 1.208 & 2.371 & 2.411 & 0.755 & RIP & 26.25 \\
\hline & B3 & 1.155 & 1.142 & 2.361 & 2.345 & 1.149 & 1.168 & 2.353 & 2.393 & 0.740 & RIII & 31.75 \\
\hline & B7 & 1.160 & 1.148 & 2.356 & 2.338 & 1.154 & 1.174 & 2.347 & 2.387 & 0.745 & RIT & 27.00 \\
\hline SCHOMACHER & 2 & 1.218 & 1.217 & 2.370 & 2.382 & 1.218 & 1.238 & 2.376 & 2.416 & 0.732 & RTI & 17.25 \\
\hline \multirow[t]{4}{*}{ SOLAR (OSED) } & 6 & 1.205 & 1.210 & 2.393 & 2.375 & 1.208 & 1.228 & 2.384 & 2.424 & 0.807 & RTT & 14.00 \\
\hline & 10. & 1.183 & 1.187 & 2.389 & 2.372 & 1.185 & 1.205 & 2.381 & 2.421 & 0.796 & RIT & 25.50 \\
\hline & 14 & 1.180 & 1.174 & 2.376 & 2.358 & 1.177 & 1.197 & 2.367 & 2.407 & 0.798 & RTT & 23.50 \\
\hline & 18 & 1.179 & 1.170 & 2.386 & 2.395 & 1.175 & 1.194 & 2.391 & 2.431 & 0.798 & RTIT & 25.25 \\
\hline SCHOMACAER & 1 & 1.210 & 1.200 & 2.392 & 2.388 & 1.205 & 1.225 & 2.390 & 2.431 & 0.741 & RIT & 40.50 \\
\hline \multirow[t]{4}{*}{ (ONOSED) } & 3 & 1.198 & 1.194 & 2.380 & 2.375 & 1.196 & 1.216 & 2.378 & 2.418 & 0.742 & RTI & 37.75 \\
\hline & 5 & 1.199 & 1.203 & 2.386 & 2.386 & 1.201 & 1.221 & 2.386 & 2.426 & 0.766 & RIT & 47.25 \\
\hline & 7 & 1.191 & 1.178 & 2.376 & 2.384 & 1.185 & 1.205 & 2.380 & 2.420 & 0.752 & RTT & 44.25 \\
\hline & 9 & 1.158 & 1.170 & 2.340 & 2.345 & 1.164 & 1.184 & 2.343 & 2.382 & 0.730 & RIT & 43.25 \\
\hline SCHOHACHER & 1 & 1.100 & 1.100 & 2.339 & 2.352 & 1.100 & 1.119 & 2.346 & 2.385 & 0.743 & RTT & 33.00 \\
\hline 5000 PULSES & 3 & 1.098 & 1.098 & 2.334 & 2.354 & 1.098 & 1.117 & 2.344 & 2.384 & 0.740 & $\mathrm{RIT}$ & 32.00 \\
\hline \multirow[t]{3}{*}{$0.5 \mathrm{sec}$} & 5 & 1.101 & 1.105 & 2.339 & 2.339 & 1.103 & 1.122 & 2.339 & 2.379 & 0.729 & RIT & 35.00 \\
\hline & 9 & 1.091 & 1.105 & 2.368 & 2.362 & 1.098 & 1.117 & 2.365 & 2.405 & 0.746 & RIT & 35.75 \\
\hline & 7 & 1.097 & 1.088 & 2.369 & 2.358 & 1.093 & 1.111 & 2.364 & 2.404 & 0.742 & RIT & 34.00 \\
\hline CHOHACHER & 1 & 1.155 & 1.167 & 2.349 & 2.346 & 1.161 & 1.181 & 2.348 & 2.387 & 0.709 & RIT & 119.00 \\
\hline KRN 7068 & 5 & 1.146 & 1.140 & 2.350 & 2.349 & 1.143 & 1.162 & 2.350 & 2.389 & 0.768 & RTT & 134.25 \\
\hline \multirow[t]{3}{*}{ (ONOSED) } & 9 & 1.126 & 1.134 & 2.350 & 2.352 & 1.130 & 1.149 & 2.351 & 2.391 & 0.772 & RIT & 131.00 \\
\hline & 12 & 1.128 & 1.109 & 2.360 & 2.358 & 1.119 & 1.137 & 2.359 & 2.399 & 0.751 & RIT & 140.75 \\
\hline & 15 & 1.114 & 1.112 & 2.357 & 2.365 & 1.113 & 1.132 & 2.361 & 2.401 & 0.785 & RIT & 154.50 \\
\hline DIDIER & 3 & 1.598 & 1.590 & 2.361 & 2.360 & 1.594 & 1.621 & 2.361 & 2.401 & 0.754 & RIT & 88.00 \\
\hline \multirow[t]{4}{*}{ (ONOSED) } & 5 & 1.511 & 1.492 & 2.361 & 2.355 & 1.502 & 1.527 & 2.358 & 2.398 & 0.752 & $\mathrm{RTT}$ & 101.75 \\
\hline & 6 & 1.500 & 1.495 & 2.365 & 2.347 & 1.498 & 1.523 & 2.356 & 2.396 & 0.748 & RTT & 85.25 \\
\hline & 8 & 1.489 & 1.493 & 2.350 & 2.358 & 1.491 & 1.516 & 2.354 & 2.394 & 0.775 & RIT & 77.25 \\
\hline & .9 & 1.481 & 1.478 & 2.348 & 2.352 & 1.480 & 1.505 & 2.350 & 2.390 & 0.786 & RTP & 95.75 \\
\hline DIDIER & 2 & 1.490 & 1.477 & 2.331 & 2.336 & 1.484 & 1.509 & 2.334 & 2.373 & 0.764 & RIT & 103.25 \\
\hline 5000 POLSES & 3 & 1.510 & 1.519 & 2.358 & 2.368 & 1.515 & 1.540 & 2.363 & 2.403 & 0.742 & RTT & 65.75 \\
\hline \multirow[t]{3}{*}{$0.05 \mathrm{sec}$} & 4 & 1.510 & 1.500 & 2.362 & 2.351 & 1.505 & 1.531 & 2.357 & 2.396 & 0.770 & RRT & 83.00 \\
\hline & 5 & 1.508 & 1.504 & 2.355 & 2.352 & 1.506 & 1.532 & 2.354 & 2.393 & 0.773 & RIT & 78.75 \\
\hline & 6 & 1.500 & 1.494 & 2.350 & 2.345 & 1.497 & 1.522 & 2.348 & 2.387 & 0.773 & RIT & 78.50 \\
\hline IFP LAYYCER & 2 & 1.575 & 1.574 & 2.321 & 2.321 & 1.575 & 1.601 & 2.321 & 2.360 & 0.761 & RIT & 36.75 \\
\hline \multirow[t]{4}{*}{ (ONOSED) } & 4 & 1.572 & 1.565 & 2.320 & 2.318 & 1.569 & 1.595 & 2.319 & 2.358 & 0.756 & RTT & 41.50 \\
\hline & 6 & 1.578 & 1.573 & 2.328 & 2.328 & 1.576 & 1.602 & 2.328 & 2.367 & 0.751 & RITI & 42.00 \\
\hline & 8 & 1.561 & 1.554 & 2.320 & 2.312 & 1.558 & 1.584 & 2.316 & 2.355 & 0.744 & RIT & 43.25 \\
\hline & 10 & 1.542 & 1.542 & 2.310 & 2.313 & 1.542 & 1.568 & 2.312 & 2.351 & 0.752 & RTI & 40.25 \\
\hline IPP LAYCER & 2 & 1.520 & 1.512 & 2.282 & 2.264 & 1.516 & 1.542 & 2.273 & 2.312 & 0.731 & RIT & 45.25 \\
\hline 5000 PULSES & 3 & 1.532 & 1.515 & 2.286 & 2.266 & 1,524 & 1.549 & 2.276 & 2.315 & 0.778 & $\mathrm{RTT}$ & 50.25 \\
\hline \multirow[t]{3}{*}{$80.05 \mathrm{sec}$} & 4 & 1.537 & 1.517 & 2.295 & 2.278 & 1.527 & 1.553 & 2.287 & 2.325 & 0.767 & RTI & 50.00 \\
\hline & 6 & 1.521 & 1.532 & 2.312 & 2.322 & 1.527 & 1.552 & 2.317 & 2.356 & 0.741 & RIT & 41.75 \\
\hline & 5 & 1.512 & 1.530 & 2.293 & 2.320 & 1.521. & 1.547 & 2.307 & 2.346 & 0.750 & RIT & 54.25 \\
\hline IFP LAYCER & 3 & 1.556 & 1.562 & 2.309 & 2.322 & 1.559 & 1.585 & 2.316 & 2.355 & 0.756 & RTT & 29.50 \\
\hline 5000 POLSES & 5 & 1.555 & 1.560 & 2.324 & 2.328 & 1.558 & 1.584 & 2.326 & 2.365 & 0.759 & $\mathrm{RTT}$ & 31.00 \\
\hline \multirow[t]{2}{*}{$80.5 \mathrm{sec}$} & 7 & 1.548 & 1.554 & 2.312 & 2.324 & 1.551 & 1.577 & 2.318 & 2.357 & 0.745 & RTT & 29.00 \\
\hline & 9 & 1.560 & 1.553 & 2.331 & 2.316 & 1.557 & 1.583 & 2.324 & 2.363 & 0.775 & RIT & 31.75 \\
\hline
\end{tabular}


05/20/91

\begin{tabular}{|c|c|c|c|c|c|c|c|c|c|c|c|}
\hline SPECIHEN & \multicolumn{2}{|c|}{$\begin{array}{l}\text { SPECIHEN TEST } \\
\text { NOKBER }\end{array}$} & $\begin{array}{l}\mathrm{Ri} \\
\text { (in.) }\end{array}$ & $\begin{array}{l}\text { Ro } \\
\text { (in.) }\end{array}$ & $\stackrel{y}{(i n)}$ & $\begin{array}{l}R=R i(T) \\
R=R O(C)\end{array}$ & $\begin{array}{r}\text { STRRSS } \\
(p s i)\end{array}$ & $\begin{array}{r}\text { STRESS } \\
(\mathrm{HPa})\end{array}$ & \multicolumn{3}{|c|}{$\begin{array}{l}\text { STRESS STRESS } \\
\text { (psi) } \quad(\mathrm{HPa})\end{array}$} \\
\hline \multicolumn{12}{|c|}{ 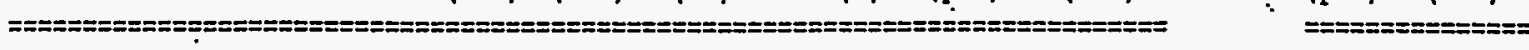 } \\
\hline SCHOHACERR & T2 & RTT & 0.62 & 1.21 & 0.78 & 0.62 & .642 & 4.43 & $M A X=$ & 864 & 5.96 \\
\hline \multirow[t]{4}{*}{ SOLAR (OROSED) } & T13 & RTT & 0.61 & 1.21 & 0.77 & 0.61 & 770 & 5.31 & HIN $=$ & 642 & 4.43 \\
\hline & T17 & RIT & 0.60 & 1.21 & 0.76 & 0.60 & 728 & 5.02 & $A V B=$ & 749 & 5.17 \\
\hline & B3 & RIT & 0.58 & 1.20 & 0.74 & 0.58 & 864 & 5.96 & $S T D=$ & 72 & 0.49 \\
\hline & B7 & RTT & 0.59 & 1.19 & 0.75 & 0.59 & 741 & 5.11 & & & \\
\hline SCHOHACHER & 2 & RIT & 0.62 & 1.21 & 0.73 & 0.62 & 515 & 3.55 & $H A X=$ & 661 & 4.56 \\
\hline \multirow[t]{4}{*}{ SOLAR (OSED) } & .6 & RITT & 0.61 & 1.21 & 0.81 & 0.61 & 369 & 2.55 & HIN $=$ & 369 & 2.55 \\
\hline & 10 & RTP & 0.60 & $\cdot 1.21$ & 0.80 & 0.60 & 661 & 4.56 & $A V B=$ & 558 & 3.85 \\
\hline & 14 & RIT & 0.60 & 1.20 & 0.80 & 0.60 & 610 & 4.20 & $S T D=$ & 106 & 0.73 \\
\hline & 18 & RIT & 0.60 & 1.22 & 0.80 & 0.60 & 635 & 4.38 & & & \\
\hline SCHOHACHER & 1 & RTT & 0.61 & 1.22 & 0.74 & 0.61 & 1150 & 7.93 & $H A X=$ & 1296 & 8.94 \\
\hline \multirow[t]{2}{*}{ (OKOSED) } & 3 & RIT & 0.61 & 1.21 & 0.74 & 0.61 & 1072 & 7.39 & HIN= & 1072 & 7.39 \\
\hline & $\cdot 5$ & RTT & 0.61 & 1.21 & 0.77 & 0.61 & 1296 & 8.94 & $\lambda V E=$ & 1194 & 8.23 \\
\hline \multirow[t]{2}{*}{ • } & 7 & RTT & 0.60 & 1.21 & 0.75 & 0.60 & 1214 & 8.37 & $S T D=$ & 77 & 0.53 \\
\hline & 9 & RIT & 0.59 & 1.19 & 0.73 & 0.59 & 1238 & 8.54 & & & \\
\hline SCHOHACHER & 1 & RTT & 0.56 & 1.19 & 0.74 & 0.56 & 839 & 5.78 & $H A X=$ & 918 & 6.33 \\
\hline 5000 POLSES & 3 & RITT & 0.56 & 1.19 & 0.74 & 0.56 & 816 & 5.62 & HIK= & 816 & 5.62 \\
\hline \multirow[t]{3}{*}{$0.5 \mathrm{sec}$} & 5 & RTP & 0.56 & 1.19 & 0.73 & 0.56 & 918 & 6.33 & $\lambda V E=$ & 859 & 5.92 \\
\hline & 9 & RTI & 0.56 & 1.20 & 0.75 & 0.56 & .883 & 6.09 & $S T D=$ & 37 & 0.25 \\
\hline & 7 & RTT & 0.56 & 1.20 & 0.74 & 0.56 & 839 & 5.79 & & & \\
\hline SCHOHKCHER & 1 & RRT & 0.59 & 1.19 & 0.71 & 0.59 & 3470 & 23.92 & $\mathrm{HAX}=$ & 3724 & 25.68 \\
\hline KRM 7068 & 5 & $\mathrm{RTT}$ & 0.58 & 1.19 & 0.77 & 0.58 & 3506 & 24.17 & HIK $=$ & 3331 & 22.97 \\
\hline (ONOSED) & 9 & RTT & 0.57 & 1.20 & 0.77 & 0.57 & 3331 & 22.97 & $\Delta V \mathrm{~V}=$ & 3523 & 24.29 \\
\hline \multirow{2}{*}{ 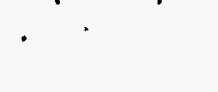 } & 12 & RIT & 0.57 & 1.20 & 0.75 & 0.57 & 3583 & 24.71 & $S T D=$ & 130 & 0.89 \\
\hline & 15 & RTT & 0.57 & 1.20 & 0.79 & 0.57 & 3724 & 25.68 & & & \\
\hline DIDIRR & 3 & RTIT & 0.81 & 1.20 & 0.75 & 0.81 & 5619 & 38.74 & $\dot{H} X X=$ & 5619 & 38.74 \\
\hline \multirow[t]{4}{*}{ (ONOSED) } & 5 & RTT & 0.76 & 1.20 & 0.75 & 0.76 & 5237 & 36.11 & HIN $=$ & 3796 & 26.17 \\
\hline & 6 & RIT & 0.76 & 1.20 & 0.75 & 0.76 & 4388 & 30.25 & $\lambda V B=$ & 4719 & 32.54 \\
\hline & 8 & RTIT & 0.76 & 1.20 & 0.78 & 0.76 & 3796 & 26.17 & $S T D=$ & 643 & 4.43 \\
\hline & 9 & RTP & 0.75 & 1.19 & 0.79 & 0.75 & 4554 & 31.40 & & & \\
\hline DIDIER & 2 & RITT & 0.75 & 1.19 & 0.76 & 0.75 & 5257 & 36.25 & $H A X=$ & 5257 & 36.25 \\
\hline 5000 POLSES & 3 & RTT & 0.77 & 1.20 & 0.74 & 0.77 & 3500 & 24.13 & $\mathrm{MINK}=$ & 3500 & 24.13 \\
\hline \multirow[t]{3}{*}{$0.05 \mathrm{sec}$} & 4 & $\operatorname{RTT}$ & 0.77 & 1.20 & 0.77 & 0.77 & 4218 & 29.08 & $A V B=$ & 4192 & 28.91 \\
\hline & 5 & RITI & 0.77 & 1.20 & 0.77 & 0.77 & 4018 & 27.70 & $S T D=$ & 582 & 4.01 \\
\hline & 6 & RIT & 0.76 & 1.19 & 0.77 & 0.76 & 3968 & $\cdot 27.36$ & & & \\
\hline IPP LAYCER & 2 & RTI & 0.80 & 1.18 & 0.76 & 0.80 & 2409 & 16.61 & $H A X=$ & 2805 & 19.34 \\
\hline \multirow[t]{3}{*}{ (ONOSED) } & 4 & RIT & 0.80 & 1.18 & 0.76 & 0.80 & 2708 & 18.67 & HIN $=$ & 2409 & 16.61 \\
\hline & 6 & RIT & 0.80 & 1.18 & 0.75 & 0.80 & 2755 & 18.99 & $A V B=$ & 2637 & 18.18 \\
\hline & 8 & RTT & 0.79 & 1.18 & -0.74 & 0.79 & 2805 & 19.34 & $S T D=$ & 152 & 1.05 \\
\hline & 10 & RIT & 0.78 & 1.18 & 0.75 & 0.78 & 2506 & 17.28 & & & \\
\hline IFP LLYCER & 2 & RTT & 0.77 & 1.16 & 0.73 & 0.77 & 2945 & 20.31 & $H A X=$ & 3246 & 22.38 \\
\hline 5000 PULSES & 3 & RIT & 0.77 & 1.16 & 0.78 & 0.77 & 3113 & 21.46 & $\mathrm{HIH}=$ & 2508 & 17.29 \\
\hline \multirow[t]{3}{*}{$00.05 \mathrm{sec}$} & 4 & RIT & 0.78 & 1.16 & 0.77 & 0.78 & 3099 & 21.37 & $\lambda V E=$ & 2982 & 20.56 \\
\hline & 6 & $\mathrm{RTT}$ & 0.78 & 1.18 & 0.74 & 0.78 & 2508 & 17.29 & $S T D=$ & 256 & 1.76 \\
\hline & 5 & RRT & 0.77 & 1.17 & 0.75 & 0.77 & 3246 & 22.38 & & & \\
\hline IFP LAYCER & 3 & RTT & 0.79 & 1.18 & 0.76 & 0.79 & 1892 & 13.05 & HAX $=$ & 1988 & 13.70 \\
\hline 5000 PULSES & 5 & RTT & 0.79 & 1.18 & 0.76 & 0.79 & 1929 & 13.30 & HIN= & 1839 & 12.68 \\
\hline \multirow[t]{2}{*}{$00.5 \mathrm{sec}$} & 7 & RTT & 0.79 & 1.18 & 0.75 & 0.79 & 1839 & 12.68 & $\mathrm{AVE}=$ & 1918 & 13.22 \\
\hline & 9 & RTT & 0.79 & 1.18 & 0.78 & 0.79 & 1940 & 13.38 & $S T D=$ & 50 & 0.34 \\
\hline
\end{tabular}


$05 / 20 / 91$

CORRECTED CORRECTED

SPECIMEN SPECIHEN I.D. 1 I.D. 2 O.D. 1 O.D. 2 AVE. I.D. I.D. AVE. 0.D. 0.D. HIDTH TEST LOAD NUTBER (in.) (in.) (in.) (in.) (in.) (in.) (in.) (in.) (in.) (lbs)

\begin{tabular}{|c|c|c|c|c|c|c|c|c|c|c|c|c|}
\hline & 11 & 1.553. & 1.548 & 2.325 & 2.330 & 1.551 & 1.577 & 2.328 & 2.367 & 0.762 & RTT & 32.75 \\
\hline IPP LAYCER & 2 & 1.515 & 1.531 & 2.330 & 2.335 & 1.523 & 1.549 & 2.333 & 2.372 & 0.755 & RTIT & 49.50 \\
\hline 1000 POLSES & 3 & 1.545 & 1.526 & 2.350 & 2.330 & 1.536 & 1.562 & 2.340 & 2.380 & 0.772 & RMT & 43.75 \\
\hline \multirow[t]{3}{*}{$80.05 \mathrm{sec}$} & 4 & 1.532 & 1.519 & 2.345 & 2.359 & 1.526 & 1.551 & 2.352 & 2.392 & 0.758 & RTT & 46.75 \\
\hline & 5 & 1.532 & 1.547 & 2.345 & 2.354 & 1.540 & 1.566 & 2.350 & 2.389 & 0.760 & RIT & 49.25 \\
\hline & 6 & 1.535 & 1.528 & 2.356 & 2.341 & 1.532 & 1.557 & 2.349 & 2.388 & 0.758 & RTT & 52.50 \\
\hline IPP LAYYCER-DOE & 3 & 1.526 & 1.512 & 2.304 & 2.301 & 1.519 & 1.545 & 2.303 & 2.342 & 0.778 & RTI & 32.25 \\
\hline \multirow[t]{5}{*}{ (OSED) } & 7 & $1.521^{\circ}$ & 1.520 & 2.310 & 2.300 & 1.521 & 1.546 & 2.305 & 2.344 & 0.751 & RIT & 26.00 \\
\hline & 11 & $1.500^{\circ}$ & 1.506 & 2.298 & 2.304 & 1.503 & 1.528 & 2.301 & 2.340 & 0.758 & RIT & 22.25 \\
\hline & 15 & 1.494 & 1.498 & 2.301 & 2.309 & 1.496 & 1.521 & 2.305 . & 2.344 & 0.776 & RIT & 26.50 \\
\hline & 21 & 1.436 & 1.442 & $2.295^{\circ}$ & 2.299 & 1.439 & 1.463 & 2.297 & 2.336 & 0.745 & RTIT & 49.25 \\
\hline & 1 & 1.163 & 1.160 & 2.347 & 2.330 & 1.162 & 1.181 & 2.339 & 2.378 & 0.761 & RIP & 96.75 \\
\hline SCHUHACAER & 5 & 1.164 & 1.163 & 2.333 & 2.349 & 1.164 & 1.183 & 2.341 & 2.381 & 0.764 & RTP. & 94.25 \\
\hline KRM 7067 & 9 & 1.132 & 1.131 & 2.343 & 2.339 & 1.132 & 1.151 & 2.341 & 2.381 & 0.760 & RIT & 97.25 \\
\hline \multirow[t]{2}{*}{ (DSED) } & 13 & 1.128 & 1.129 & 2.348 & 2.341 & 1.129 & 1.148 & 2.345 & 2.384 & 0.752 & RTP & 107.50 \\
\hline & 17 & 1.110 & 1.110 & 2.353 & 2.349 & 1.110 & 1.129 & 2.351 & 2.391 & 0.750 & RIT & 99.25 \\
\hline SCHOHACHER & 1 & 1.165 & 1.163 & 2.347 & 2.342 . & 1.164 & 1.184 & 2.345 & 2.384 & 0.753 & $\operatorname{RIT}$ & 94.25 \\
\hline KR⿴囗十 7052 & 5 & 1.159 & 1.162 & 2.342 & 2.341 & 1.161 & 1.180 & 2.342 & 2.381 & 0.759 & RIT & 96.75 \\
\hline \multirow[t]{3}{*}{ (OSED) } & 9 & 1.139 & 1.144 & 2.346 & 2.349 & 1.142 & 1.161 & 2.348 & 2.387 & 0.756 & RTT & 110.75 \\
\hline & 13 & 1.122 & 1.124 & 2.349 & 2.352 & 1.123 & 1.142 & 2.351 & 2.390 & 0.752 & RIT & 101.75 \\
\hline & 17 & 1.112 & 1.110 & 2.348 & 2.348 & 1.111 & 1.130 & 2.348 & 2.388 & 0.759 & BIII & 94.25 \\
\hline SCHOLACHER & T3 & 1.167 & 1.177 & 2.325 & 2.317 & 1.172 & 1.192 & 2.321 & 2.360 & 0.744 & $\mathrm{HTT}$ & .20 .50 \\
\hline SOLAR (OTOSED) & T14 & 1.161 & 1.172 & 2.352 & 2.354 & 1.167 & 1.186 & 2.353 & 2.393 & 0.750 & HTTP & 24.00 \\
\hline \multirow[t]{3}{*}{$980 \mathrm{C}$} & T18 & 1.139 & 1.142 & 2.330 & 2.315 & 1.141 & 1.160 & 2.323 & 2.362 & 0.771 & HTP & 24.75 \\
\hline & $B 4$ & 1.129 & 1.116 & 2.341 & 2.315 & 1.123 & 1.142 & 2.328 & 2.367 & .0 .752 & HWT & 25.50 \\
\hline & B8 & 1.127 & 1.122 & 2.330 & 2.312 & 1.125 & 1.144 & 2.321 & 2.360 & 0.743 & EIT & 22.50 \\
\hline SCHUHACHER & 3 & 1.188 & 1.193 & 2.368 & 2.355 & 1.191 & 1.211 & 2.362 & 2.402 & 0.796 & HTPT & 20.75 \\
\hline SOLAR (OSED) & 7 & 1.181 & 1.180 & 2.362 & 2.345 & 1.181 & 1.201 & 2.354 & 2.393 & 0.786 & $\operatorname{ETT}$ & 15.50 \\
\hline \multirow[t]{3}{*}{$980 \mathrm{C}$} & 11 & 1.157 & 1.159 & 2.360 & 2.349 & 1.158 & 1.178 & 2.355 & 2.394 & 0.795 & EITT & 25.00 \\
\hline & 15 & 1.155 & 1.154 & 2.361 & 2.345 & 1.155 & 1.174 & 2.353 & 2.393 & 0.798 & HTT & 22.00 \\
\hline & 19 & 1.111 & 1.111 & 2.344 & 2.369 & 1.111 & 1.130 & 2.357 & 2.396 & 0.797 & ETIT & 14.75 \\
\hline SCHOHACHER & 2 & 1.179 & 1.185 & 2.365 & 2.369 & 1.182 & 1.202 & 2.367 & 2.407 & 0.748 & BIT & 45.50 \\
\hline (ONOSED) & 4 & 1.184 & 1.179 & 2.362 & 2.364 & 1.182 & 1.202 & 2.363 & 2.403 & 0.761 & BTIT & 42.25 \\
\hline \multirow[t]{3}{*}{$.870 C$} & 6 & 1.164 & 1.177 & 2.360 & 2.355 & 1.171 & 1.190 & 2.358 & 2.397 & 0.763 & BTT & 45.25 \\
\hline & 8 & 1.160 & 1.155 & 2.362 & 2.359 . & 1.158 & 1.177 & 2.361 & 2.401 & 0.760 & BTT & 44.50 \\
\hline & 10 & 1.142 & 1.145 & 2.342 & 2.342 & 1.144 & 1.163 & 2.342 & 2.382 & 0.720 & HITT & 49.50 \\
\hline SCHOMACHER & 2 & 1.100 & 1.100 & 2.330 & 2.356 & 1.100 & 1.119 & 2.343 & 2.383 & 0.755 & Bगया & 43.25 \\
\hline \multicolumn{13}{|l|}{$\begin{array}{c}\text { e } 0.5 \mathrm{sec} \\
870 \mathrm{C}\end{array}$} \\
\hline IPP LAYCER-DOB & 4 & 1.530 & 1.522 & 2.302 & 2.293 & 1.526 & 1.552 & 2.298 & 2.336 & 0.750 & BTT & 26.75 \\
\hline (USED) & 8 & 1.520 & 1.511 & 2.310 & 2.303 & 1.516 & 1.541 & 2.307 & 2.346 & 0.760 & HITT & 21.50 \\
\hline \multirow[t]{3}{*}{$870 \mathrm{C}$} & 12 & 1.499 & 1.507 & 2.296 & .2 .304 & 1.503 & 1.528 & 2.300 & 2.339 & 0.760 & HTi & 24.50 \\
\hline & 16 & 1.488 & 1.500 & 2.300 & 2.314 & 1.494 & 1.519 & 2.307 & 2.346 & 0.772 & HTT & 31.50 \\
\hline & 22 & 1.435 & 1.440 & 2.291 & 2.298 & 1.438 & 1.462 & 2.295 & 2.333 & 0.752 & HTT & 45.25 \\
\hline IFP LAYCER & 3 & 1.566 & 1.569 & 2.321 & 2.321 & 1.568 & 1.594 & 2.321 & 2.360 & 0.755 & HIT & 30.00 \\
\hline (UNOSED) & 5 & 1.543 & 1.563 & 2.316 & 2.314 & 1.553 & 1.579 & 2.315 & 2.354 & 0.745 & BTT & 31.00 \\
\hline $870 \mathrm{C}$ & 7 & 1.563 & 1.559 & 2.320 & 2.316 & 1.561 & 1.587 & 2.318 & 2.357 & 0.759 & BIT & 38.25 \\
\hline
\end{tabular}


$05 / 20 / 91$

SPECIHEN SPECIHEN TEST Ri RO W R=Ri(T) STRESS STRESS

$=============$
IPP LAYCER
1000 POLSES
60.05 sec

11

RTT

(in.) (in.)

(in) $R=R o(C)$ (psi) (HPa)

$\begin{array}{llll}\text { RIT } & 0.77 & 1.19 & 0.76\end{array}$

$\begin{array}{llll}\operatorname{RTP} & 0.78 & 1.19 & 0.77\end{array}$

$\begin{array}{llll}\text { RTT } & 0.78 & 1.20 & 0.76\end{array}$

$\begin{array}{rr}0.79 & -1988 \\ 0.77 & 2804\end{array}$

$0.78 \quad 2461$

$0.78 \quad 2553$
NOTBER

$\begin{array}{llll}0.76 & 0.79 & -1988 & 13.70\end{array}$

RTT

RTT

0.78

0.78

1.19

0.76

0.76

$\begin{array}{lll}\text { RIT } & 0.77 & 1.17\end{array}$

0.78

0.75

$\begin{array}{lll}\text { RTT } & 0.77 & 1.17\end{array}$

$\begin{array}{lll}\text { RIT' } & 0.76 & 1.17\end{array}$

0.76

0.78

RTT

$\begin{array}{ll}0.76 & 1.17\end{array}$

0.75

RIT

$\begin{array}{ll}0.73 & 1.17\end{array}$

0.75
0.76

RTT

$0.59 \quad 1.19$

SCHOHACHER

KRI 7067

(DSED)

SCHOHACBER
KRH 7052
(OSED)

SCHOMACHER
SOLAR (ONOSED)
$\quad 980 \mathrm{C}$

$980 \mathrm{C}$

RII

$\begin{array}{lll}\text { RTT } & 0.58 & 1.19\end{array}$

0.76

0.76

RI

RIT

$0.57 \quad 1.19$

0.75

0.75

RIT

RT

RIT

0.561 .20

0.75

0.591 .19

0.76

$\begin{array}{lll}0.58 & 1.19 & 0.76 \\ 0.19 & 0.76\end{array}$

RIT

RT

T3

HITT

$0.57 \quad 1.20$

0.75

0.76

HII

HIP

B4 HI

SCHOHACHER

SOLAR (OSED)

$980 \mathrm{C}$

SCHOHACHER
(ONOSED)
. $870 C$

SCHOHACHER
5000 POLSES
Q $0.5 \mathrm{sec}$
$870 \mathrm{C}$

IPP LAYCER-DOB

$$
\text { (OSED) }
$$

$870 \mathrm{C}$

$$
\begin{array}{r}
8 \\
12 \\
16
\end{array}
$$$$
\begin{aligned}
& 16 \\
& 22
\end{aligned}
$$

IFP LAYCER

(UNOSED)

$870 \mathrm{C}$
$0.78 \quad 2788$

0.78

0.77

0.77

0.76

0.76

0.73

0.59

0.59

0.58

0.57

0.56

0.59

0.59

0.58

0.57

0.56

0.60

0.59

0.58

0.57

0.57

0.61

0.60

0.59

0.59

0.56

0.60

0.60

0.60

0.59

0.58

0.56

0.55
2928

1867

1557

1274

1446

2488 .

2659

2580

2547

2821

2521

2609

2652

2938

2630

2377

599

663

662 .

676

610

555

417

642

560

351

1269

1163

1229

1185

1392

1085

1066
0.72

19.33

16.97

17.60

19.22

20.19

12.87

10.73

8.79

9.97

17.15

18.33

17.79

17.56

19.45

17.38

17.99

18.29

20.26

18.13

16.39

4.13

4.57

4.57

4.66

4.21

3.83

2.88

4.42

3.86

2.42

8.75

8.02

8.48

8.17

9.60

7.48

7.35

$H A X=2928$

MIS $=2461$

$\mathrm{AVE}=2707$

$S T D=173$

$\begin{array}{lr}\text { (psi) } & \text { (MPa) } \\ ===== & \\ & \\ 2928 & 20.19 \\ 2461 & 16.97 \\ 2707 & 18.66 \\ 173 & 1.19\end{array}$

$\begin{array}{lr}\text { (psi) } & \text { (MPa) } \\ ===== & \\ & \\ 2928 & 20.19 \\ 2461 & 16.97 \\ 2707 & 18.66 \\ 173 & 1.19\end{array}$

$\begin{array}{lr}\text { (psi) } & \text { (MPa) } \\ ===== & \\ & \\ 2928 & 20.19 \\ 2461 & 16.97 \\ 2707 & 18.66 \\ 173 & 1.19\end{array}$

HAX $=2488 \quad 17.15$

HIIY $=1274 \quad 8.79$

$\triangle V E=1726 \quad 11.90$

$S T D=427 \quad 2.94$

HAX $=2821 \quad 19.45$

$\mathrm{HIH}=2521 \quad 17.38$

$\mathrm{AVE}=2626 \quad 18.10$

$S T D=108 \quad 0.74$

$\mathrm{HAX}=2938 \quad 20.26$

$\mathrm{HIN}=2377 \quad 16.39$

$\mathrm{AVB}=2641 \quad 18.21$

$S T D=178 \quad 1.23$

HAX $=676 \quad 4.66$

HIN $=599 \quad 4.13$

$\triangle V E=642 \quad 4.43$

$S T D=31 \quad 0.21$

$H A X=642 \quad 4.42$

HIH $=351 \quad 2.42$

$\triangle V E=505 \quad 3.48$

$S T D=106 \quad 0.73$

$H A X=1392 \quad 9.60$

HIH $=1163 \quad 8.02$

$\mathrm{AVE}=1248 \quad 8.60$

$\mathrm{STD}=81 \quad 0.56$

$\triangle V E=1075 \quad 7.41$

$S T D=\begin{array}{ll}10 & 0.07\end{array}$ 
$05 / 20 / 91$

CORRECTED CORRECTED

SPECIMEN SPECIHEN I.D. 1 I.D. 2 0.D. 1 0.D. 2 AVE. I.D. I.D. AVE. 0.D. 0.D. WIDTH TEST LOAD NOHBER (in.) (in.) (in.) (in.) (in.) (in.) (in.) (in.) (in.) (lbs)

\begin{tabular}{|c|c|c|c|c|c|c|c|c|c|c|c|c|}
\hline & 9 & 1.558 & 1.550 & 2.313 & 2.307 & 1.554 & 1.580 & 2.310 & 2.349 & 0.751 & ETHT & 40.00 \\
\hline & 11 & 1.545 & 1.544 & 2.304 & 2.300 & 1.545 & 1.571 & 2.302 & $2.341^{\circ}$ & 0.754 & HWT & 41.25 \\
\hline IPP LAYCER & 2 & 1.554 & 1.556 & 2.306 & 2.318 & 1.555 & 1.581 & 2.312 & 2.351 & 0.750 & BiTP & 38.00 \\
\hline 5000 POLSES & 4 & 1.542 & 1.561 & 2.309 & 2.317 & 1.552 & 1.578 & 2.313 & 2.352 & 0.739 & BIT & 37.50 \\
\hline $80.5 \mathrm{sec}$ & 6 & 1.562 & 1.547 & 2.325 & 2.327 & 1.555 & 1.581 & 2.326 & 2.365 & 0.765 & BTT & 47.25 \\
\hline \multirow[t]{2}{*}{$870 \mathrm{C}$} & 8 & .1 .553 & 1.560 & 2.322 & 2.330 & 1.557 & 1.583 & 2.326 & 2.365 & 0.759 & BTPT & 39.25 \\
\hline & 10 & 1.550 & 1.544 & 2.326 & 2.315 & 1.547 & 1.573 & 2.321 & 2.360 & 0.743 & HIPT & 45.00 \\
\hline SCHOHACHRR & 2 & 1.165 & 1.158 & 2.350 & 2.350 & 1.162 & 1.181 & 2.350 & 2.390 & 0.773 & HTT & 131.75 \\
\hline KRW 7068 & 6 & 1.144 & 1.148 & 2.346 & 2.348 & 1.146 & 1.165 & 2.347 & 2.387 & 0.755 & HITT & 132.00 \\
\hline \multirow[t]{3}{*}{ (ONOSED) $650 \mathrm{C}$} & 10 & 1.122 & 1.132 & 2.358 & .2 .357 & 1.127 & 1.146 & 2.358 & 2.397 & 0.773 & BTT & 141.50 \\
\hline & 13 & 1.120 & 1.112 & 2.361 & 2.359 & 1.116 & 1.135 & $\cdot 2.360$ & 2.400 & 0.768 & BTPS & 144.75 \\
\hline & 16 & 1.111 & 1.112 & 2.356 & 2.363 & 1.112 & 1.130 & 2.360 & 2.399 & 0.770 & ETT & 161.25 \\
\hline SCHOLACHER & 2 & 1.163 & 1.155 & 2.345 & 2.341 & 1.159 & 1.179 & 2.343 & 2.383 & 0.760 & ETT & 102.00 \\
\hline KRP 7052 & 6 & 1.150 & 1.149 & 2.347 & 2.340 & 1.150 & 1.169 & 2.344 & 2.383 & 0.758 & ETT & 113.75 \\
\hline \multirow[t]{3}{*}{ (USED) $650 \mathrm{C}$} & 10 & 1.128 & 1.137 & 2.348 & 2.344 & 1.133 & 1.152 & 2.346 & 2.386 & 0.758 & HITT & 105.25 \\
\hline & 14 & 1.118 & 1.114 & 2.354 & 2.348 & 1.116 & 1.135 & 2.351 & 2.391 & 0.763 & BTT & 115.50 \\
\hline & 18 & 1.110 & .1 .113 & 2.349 & 2.348 & 1.112 & 1.130 & 2.349 & 2.388 & 0.768 & BTT & 108.75 \\
\hline SCHOMACHER & 2 & 1.158 & 1.167 & 2.340 & 2.326 & 1.163 & 1.182 & 2.333 & 2.373 & 0.753 & HIT & 110.50 \\
\hline KRH 7067 & 6 & 1.148 & 1.145 & 2.341 & 2.330 & 1.147 & 1.166 & 2.336 & 2.375 & 0.760 & HIT & 112.25 \\
\hline \multirow[t]{3}{*}{ (OSED) $650 \mathrm{C}$} & 10 & 1.128 & 1.128 & 2.347 & 2.334 & 1.128 & 1.147 & 2.341 & 2.380 & 0.758 & BIT & 119.50 \\
\hline & 14 & 1.108 & 1.116 & 2.349 & 2.341 & 1.112 & 1.131 & .2 .345 & 2.385 & 0.764 & BITP & 119.25 \\
\hline & 18 & 1.111 & 1.113 & 2.348 & 2.352 & 1.112 & 1.131 & 2.350 & 2.390 & 0.757 & BITT & 125.75 \\
\hline SCHOMACHER & $\mathrm{T} 4$ & 1.190 & 1.203 & 2.365 & 2.349 & 1.197 & 1.217 & 2.357 & 2.397 & 0.753 & RTC & -48.00 \\
\hline \multirow[t]{4}{*}{ SOLAR (OFOSED) } & T15 & 1.165 & 1.173 & 2.353 & 2.343 & 1.169 & 1.189 & 2.348 & 2.388 & 0.780 & RTC & -48.25 \\
\hline & $\mathrm{T19}$ & 1.155 & 1.163 & 2.358 & 2.345 & 1.159 & 1.179 & 2.352 & 2.391 & 0.764 & RTC & -53.50 \\
\hline & B5 & 1.143 & 1.132 & 2.354 & 2.337 & 1.138 & 1.157 & 2.346 & 2.385 & 0.754 & RTC & -52.75 \\
\hline & B9 & 1.125 & 1.141 & 2.313 & 2.339 & 1.133 & 1.152 & 2.326 & 2.365 & 0.742 & RTC & -45.00 \\
\hline SCHOHACHER & 4 & 1.187 & 1.191 & 2.366 & 2.352 & 1.189 & 1.209 & 2.359 & 2.399 & 0.804 & RTC & -22.75 \\
\hline \multirow[t]{4}{*}{ SOLAR (OSED) } & 8 & 1.170 & 1.176 & 2.366 & 2.352 & 1.173 & 1.193 & 2.359 & 2.399 & 0.785 & $\operatorname{RTC}$ & -15.00 \\
\hline & 12 & 1.150 & 1.159 & 2.366 & 2.355 & 1.155 & 1.174 & 2.361 & 2.401 & 0.795 & RTC & -49.00 \\
\hline & 16 & 1.150 & 1.155 & 2.364 & 2.354 & 1.153 & 1.172 & 2.359 & 2.399 & 0.793 & RTC & -48.50 \\
\hline & 20 & 1.110 & 1.105 & 2.345 & 2.332 & 1.108 & 1.126 & 2.339 & 2.378 & 0.790 & RTC & -45.50 \\
\hline \multirow{5}{*}{$\begin{array}{l}\text { IIPP LAYCER-DOE } \\
\text { (OSED) }\end{array}$} & 9 & 1.516 & 1.512 & 2.305 & 2.306 & 1.514 & 1.540 & 2.306 & 2.345 & 0.759 & RTC & -80.75 \\
\hline & 13 & 1.500 & 1.503 & 2.302 & 2.308 & 1.502 & 1.527 & 2.305 & 2.344 & 0.752 & RTC & -89.25 \\
\hline & 17 & 1.493 & 1.493 & 2.303 & 2.303 & 1.493 & 1.518 & 2.303 & 2.342 & 0.782 & RIC & -79.00 \\
\hline & 23 & 1.434 & 1.441 & 2.292 & $2.299^{\circ}$ & 1.438 & 1.462 & 2.296 & 2.334 & 0.760 & RTC & -108.25 \\
\hline & 27 & 1.422 & 1.420 & 2.292 & 2.291 & 1.421 & 1.445 & 2.292 & 2.330 & 0.732 & RTC & -99.00 \\
\hline SCHOKACHER & 3 & 1.158 & 1.163 & 2.342 & 2.347 & 1.161 & 1.180 & $2: 345$ & 2.384 & 0.761 & RTC & -227.50 \\
\hline $\mathrm{KRH} 7068$ & 7 & 1.138 & 1.146 & 2.347 & 2.350 & 1.142 & 1.161 & 2.349 & 2.388 & 0.780 & RTC & -236.75 \\
\hline \multirow{3}{*}{ (ONOSED) } & 11 & 1.113 & 1.120 & 2.349 & 2.351 & 1.117 & 1.135 & 2.350 & 2.390 & 0.773 & RTC & -252.50 \\
\hline & 14 & 1.116 & 1.111 & 2.363 & 2.362 & 1.114 & 1.132 & 2.363 & 2.403 & 0.772 & RTC & -262.00 \\
\hline & 17 & 1.110 & 1.111 & 2.357 & 2.361 & 1.111 & 1.129 & 2.359 & 2.399 & 0.760 & RTC & -282.50 \\
\hline SCHOMACHER & 3 & 1.162 & 1.163 & 2.347 & 2.342 & 1.163 & 1.182 & 2.345 & 2.384 & 0.762 & RTC & -169.00 \\
\hline KRH 7052 & 7 & 1.139 & 1.148 & 2.346 & 2.342 & 1.144 & 1.163 & 2.344 & 2.384 & 0.757 & RirC & -194.25 \\
\hline \multirow[t]{3}{*}{ (USED) } & 11 & 1.113 & 1.130 & 2.350 & 2.347 & 1.122 & 1.141 & $2.349^{\circ}$ & 2.388 & 0.761 & RTC & -191.75 \\
\hline & 15 & 1.107 & 1.107 & 2.348 & 2.348 & 1.107 & 1.126 & 2.348 & 2.388 & 0.766 & RTC & -214.25 \\
\hline & 19 & 1.113 & 1.111 & 2.354 & 2.354 & 1.112 & 1.131 & 2.354 & 2.394 & 0.760 & RTC & -260.50 \\
\hline SCROMACHER & 3 & 1.161 & 1.160 & 2.337 & 2.325 & 1.161 & 1.180 & 2.331 & 2.371 & 0.754 & RTC & -225.25 \\
\hline KRH 7067 & 7 & 1.150 & 1.155 & 2.343 & 2.336 & 1.153 & 1.172 & 2.340 & 2.379 & 0.759 & RTC & -225.75 \\
\hline
\end{tabular}


$05 / 20 / 91$

\begin{tabular}{|c|c|c|c|c|c|c|c|c|c|c|c|}
\hline SPECIHEN & \multicolumn{2}{|c|}{$\begin{array}{l}\text { SPECIHEN TEST } \\
\text { NONBER }\end{array}$} & $\begin{array}{c}\mathrm{Ri} \\
\text { (in.) }\end{array}$ & $\begin{array}{c}\text { Ro } \\
\text { (in.) }\end{array}$ & (in) & $\begin{array}{c}\mathrm{R}=\mathrm{Ri}(\mathrm{T}) \\
\mathrm{R}=\mathrm{Ro}(\mathrm{C}) \\
========\end{array}$ & $\begin{array}{l}\text { STRESS } \\
\text { (psi) }\end{array}$ & $\begin{array}{l}\text { STRESS } \\
(\mathrm{MPa})\end{array}$ & \multicolumn{3}{|c|}{$\begin{array}{l}\text { STRESS STRESS } \\
\begin{array}{l}\text { (psi) (MPa) } \\
=============\end{array}\end{array}$} \\
\hline & 9 & BTPT & 0.79 & 1.17 & 0.75 & 0.79 & -2580 & $17.79^{\circ}$ & $S T D=$ & 293 & 2.02 \\
\hline & 11 & HTPT & 0.79 & 1.17 & 0.75 & 0.79 & 2631 & 18.14 & & & \\
\hline P LAYCRR & 2 & HIT & 0.79 & 1.18 & 0.75 & 0.79 & 2450 & 16.89 & $\mathrm{HRX}=$ & 2895 & 19.96 \\
\hline 5000 POLSES & 4 & BIT & 0.79 & 1.18 & 0.74 & 0.79 & 2427 & 16.73 & MIN $=$ & 2427 & 16.73 \\
\hline $80.5 \mathrm{sec}$ & 6 & BIT & 0.79 & 1.18 & 0.77 & 0.79 & 2895 & 19.96 & $\triangle \nabla B=$ & 2605 & 17.96 \\
\hline $870 \mathrm{C}$ & 8 & BIT & 0.79 & 1.18 & 0.76 & 0.79 & 2436 & 16.80 & $S T D=$ & 207 & 1.42 \\
\hline & 10 & BIT & 0.79 & 1.18 & 0.74 & 0.79 & 2818 & 19.43 & & & \\
\hline CHOHACBER & 2 & ВIT & 0.59 & 1.19 & 0.77 & 0.59 & 3516 & 24.24 & $H 2 X=$ & 3961 & 27.31 \\
\hline RRP 7068 & 6 & BIT & 0.58 & 1.19 & 0.76 & 0.58 & 3533 & 24.36 & MIN $=$ & 3516 & 24.24 \\
\hline (ONOSED) $650 \mathrm{C}$ & 10 & BIT & 0.57 & 1.20 & 0.77 & 0.57 & 3550 & 24.48 & $\mathrm{AVB}=$ & 3629 & 25.02 \\
\hline & 13 & BIग & 0.57 & 1.20 & 0.77 & 0.57 & 3586 & 24.73 & $S T D=$ & 167 & 1.15 \\
\hline & 16 & $\mathrm{HTT}$ & 0.57 & 1.20 & 0.77 & 0.57 . & 3961 & 27.31 & & & \\
\hline DHOLACHER & 2 & BIT & 0.59 . & 1.19 & 0.76 & 0.59 & 2781 & 19.17 & $\mathrm{HMX}=$ & 3062 & 21.11 \\
\hline KRN 7052 & 6 & BTT & 0.58 & 1.19 & 0.76 & 0.58 & 3062 & 21.11 & HIN $=$ & 2711 & 18.69 \\
\hline (USED) $650 \mathrm{C}$ & 10 & HFT & 0.58 & 1.19 & 0.76 & 0.58 & 2752 & 18.97 & $\mathrm{AVE}=$ & 2843 & 19.60 \\
\hline & 14 & HIT & 0.57 & 1.20 & 0.76 & 0.57 & 2910 & 20.06 . & $S T D=$ & 128 & 0.88 \\
\hline & 18 & BIT & 0.57 & 1.19 & 0.77 & 0.57 & 2711 & $18.69^{\circ}$ & & & \\
\hline CHOHACHER & 2 & BTII & 0.59 & 1.19 & 0.75 & 0.59 & 30.95 & 21.34 & $\mathrm{HAX}=$ & 3178 & 21.91 \\
\hline KRR 7067 & 6 & $\mathrm{BTT}$ & 0.58 & i:19 & 0.76 & 0.58 & 3028 & 20.88 & $\mathrm{HINH}=$ & 3003 & 20.70 \\
\hline (USED) $650 \mathrm{C}$ & 10 & HIT & 0.57 & 1.19 & 0.76 & 0.57 & 3123 & 21.53 & $\triangle V B=$ & 3085 & 21.27 \\
\hline & 14 & HTP & 0.57 & 1.19 & 0.76 & 0.57 & 3003 & 20.70 & $S T D=$ & 63 & 0.44 \\
\hline & 18 & HTTS & 0.57 & 1.19 & 0.76 & 0.57 & 3178 & 21.91 & & & \\
\hline SCHOHACHER & T4 & RIC & 0.61 & 1.20 & 0.75 & 1.20 & 700 & 4.82 & $\mathrm{HAX}=$ & 708 & 4.88 \\
\hline SOLAR (ONOSED) & T15 & RTC & 0.59 & 1.19 & 0.78 & 1.19 & 644 & 4.44 & $\mathrm{HIH}=$ & 600 & 4.14 \\
\hline & T19 & RTC & 0.59 & 1.20 & 0.76 & 1.20 & 708 & 4.88 & $A V E=$ & 666 & 4.59 \\
\hline & B5 & RTC & 0.58 & 1.19 & 0.75 & 1.19 & 678 & 4.67 & $S T D=$ & 40 & 0.27 \\
\hline & B9 & RTC & 0.58 & 1.18 & 0.74 & 1.18 . & 600 & 4.14 & & & \\
\hline SCHOHACHER & 4 & RTC & 0.60 & 1.20 & 0.80 & 1.20 & 304 & 2.10 & $M A X=$ & 607 & 4.19 \\
\hline SOLAR (OSED) & 8 & RTC & 0.60 & 1.20 & 0.79 & 1.20 & 197 & 1.36 & $\mathrm{HIM}=$ & 197 & 1.36 \\
\hline & 12 & RTC & 0.59 & 1.20 & 0.80 & 1.20 & 607 & 4.19 & $A V E=$ & 447 & 3.08 \\
\hline & 16 & RTC & 0.59 & 1.20 & 0.79 & 1.20 & 601 & 4.15 & $S T D=$. & 166 & 1.15 \\
\hline & 20 & RTC & 0.56 & 1.19 & 0.79 & 1.19 & 525 & 3.62 & & & \\
\hline IPP LAYYCER-DOE & 9 & RTC & 0.77 & 1.17 & 0.76 & 1.17 & 3088 & 21.29 & HAX $=$ & 3354 & 23.13 \\
\hline (OSED) & 13 & RTC & 0.76 & 1.17 & 0.75 & 1.17 & 3317 & 22.87 & $\mathrm{HIK}=$ & 2764 & 19.06 \\
\hline & 17 & RTC & 0.76 & 1.17 & 0.78 & 1.17 & 2764 & 19.06 & $A V E=$ & 3117 & 21.49 \\
\hline & 23 & RTC & 0.73 & 1.17 & 0.76 & 1.17 & 3354 & 23.13 & $S T D=$ & 212 & 1.46 \\
\hline & 27 & RTC & 0.72 & 1.17 & 0.73 & 1.17 & 3062 & 21.11 & & & \\
\hline SCEUMACHER & 3 & RTC & 0.59 & 1.19 & 0.76 & 1.19 & 3068 & 21.15 & $\mathrm{HAX}=$ & 3306 & 22.80 \\
\hline KRH 7068 & 7 & RTC & 0.58 & 1.19 & 0.78 & 1.19 & 2959 & 20.40 & MIN $=$ & 2959 & 20.40 \\
\hline (OKOSED) & 11 & RTC & 0.57 & 1.19 & 0.77 & 1.19 & 2989 & 20.61 & $\mathrm{AVB}=$ & 3069 & 21.16 \\
\hline & 14 & RTC & 0.57 & 1.20 & 0.77 & 1.20 & 3024 & 20.85 & $\mathrm{STD}=$ & 124 & 0.86 \\
\hline & 17 & .RTC & 0.56 & 1.20 & 0.76 & 1.20 & 3306 & 22.80 & & & \\
\hline CEUTHACHER & 3 & RTC & 0.59 & 1.19 & 0.76 & 1.19 & 2287 & 15.77 & $\operatorname{HAX}=$ & 3083 & 21.26 \\
\hline KRN 7052 & 7 & RTC & 0.58 & 1.19 & 0.76 & 1.19 & 2529 & 17.44 & HIR $=$ & 2287 & 15.77 \\
\hline (DSED) & 11 & RTC & 0.57 & 1.19 & 0.76 & 1.19 & 2339 & 16.12 & $A V B=$ & 2549 & 17.58 \\
\hline & 15 & RTC & 0.56 & 1.19 & 0.77 & 1.19 & 2510 & 17.30 & $S T D=$ & 283 & 1.95 \\
\hline & 19 & RTC & 0.57 & 1.20 & 0.76 & 1.20 & 3083 & 21.26 & & & \\
\hline HOHAC & 3 & RTC & 0.59 & 1.19 & 0.75 & 1.19 & 3134 & 21.61 & $\mathrm{HAX}=$ & 3206 & 22.11 \\
\hline KRH 7067 & 7 & RTC & 0.59 & 1.19 & 0.76 & 1.19 & 3018 & 20.81 & HIN $=$ & 2830 & 19.51 \\
\hline
\end{tabular}


$05 / 20 / 91$

CORRECTED CORRECTED

SPECIHEN SPECIHEN I.D. 1 I.D. 2 0.D. 1 O.D. 2 AVE. I.D. I.D. AVE. 0.D. 0.D. WIDTH TRST LOAD NUMBER (in.) (in.) (in.) (in.) (in.) (in.) (in.) $\because$ (in.) (in.) (lbs)

\begin{tabular}{|c|c|c|c|c|c|c|c|c|c|c|c|c|}
\hline \multirow[t]{3}{*}{ (USED) } & 11 & 1.125 & 1.125 & 2.346 & 2.340 & 1.125 & 1.144 & 2.343 & 2.383 & 0.767 & RTC & -260.50 \\
\hline & 15 & 1.108 & 1.104 & 2.345 & 2.341 & 1.106 & 1.125 & 2.343 & 2.383 & 0.761 & RTC & -238.75 \\
\hline & 19 & 1.102 & 1.110 & 2.362 & 2.355 & 1.106 & 1.125 & 2.359 & 2.398 & 0.760 & RTC & -250.25 \\
\hline SCHOHACHER & $\mathbb{T 5}$ & 1.191 & 1.197 & 2.369 & 2.355 & 1.194 & 1.214 & 2.362 & 2.402 & 0.748 & $\operatorname{BMC}$ & -39.00 \\
\hline SOLAR (ONOSED) & T16 & 1.162 & 1.167 & 2.354 & 2.344 & 1.165 & 1.184 & 2.33 .9 & 2.389 & 0.748 & HTC & -36.50 \\
\hline \multirow[t]{3}{*}{$980 \mathrm{C}$} & $\mathrm{T} 20$ & 1.155 & 1.156 & 2.342 & 2.348 & 1.156 & 1.175 & 2.345 & 2.385 & 0.754 & HIC & -36.50 \\
\hline & B10 & 1.141 & 1.160 & 2.333 & 2.355 & 1.151 & 1.170 & 2.344 & 2.384 & 0.752 & BTC & -40.25 \\
\hline & B2 & 1.140 & 1.135 & 2.352 & 2.323 & 1.138 & 1.157 & 2.338 & 2.377 & 0.743 & HTC & -37.00 \\
\hline SCHOHACHER & 5 & 1.173 & 1.190 & 2.373 & 2.362 & 1.182 & 1.202 & 2.368 & 2.408 & 0.808 & $\mathrm{HIC}$ & -30.75 \\
\hline SOLAR (BSED) & 9 & 1.168 & 1.150 & 2.332 & 2.327 & 1.159 & 1.179 & 2.330 & 2.369 & 0.803 & BIC & -26.75 \\
\hline \multirow[t]{3}{*}{$980 \mathrm{C}$} & 13 & 1.138 & 1.132 & 2.347 & 2.332 & 1.135 & 1.154 & 2.340 & 2.379 & 0.803 & BTIC & -31.75 \\
\hline & 17 & 1.146 & 1.156 & 2.341 & 2.354 & 1.151 & 1.171 & 2.348 & 2.387 & 0.775 & HTC & -24.75 \\
\hline & 21 & 1.108 & 1.109 & 2.342 & 2.360 & 1.109 & 1.127 & 2.351 & 2.391 & 0.790 & $\mathrm{BTC}$ & -34.50 \\
\hline IFP LLYCER-DOB & 6 & 1.525 & 1.513 & 2.300 & 2.289 & 1.519 & 1.545 & 2.295 & 2.333 & 0.745 & $\mathrm{ETC}$ & -69.50 \\
\hline (OSED) & 10 & 1.501 & 1.511 & 2.298 & 2.303 & 1.506 & 1.532 & 2.301 & 2.339 & 0.762 & HTC & -73.25 \\
\hline \multirow[t]{3}{*}{$870 \mathrm{C}$} & 14 & 1.492 & 1.500 & 2.301 & 2.305 & 1.496 & 1.521 & 2.303 & 2.342 & 0.763 & HTC & -59.00 \\
\hline & 20 & 1.434 & 1.444 & 2.293 & 2.298 & 1.439 & 1.463 & 2.296 & 2.334 & 0.759 & $\mathrm{HH}^{2} \mathrm{C}$ & -83.00 \\
\hline & 24 & 1.429 & 1.443 & 2.308 & 2.311 & 1.436 & 1.460 & 2.310 & 2.349 & 0.773 & HTC & -89.75 \\
\hline SCHORACHRRR & 4 & 1.147 & 1.143 & 2.342 & 2.346 & 1.145 & 1.164 & 2.344 & 2.384 & 0.759 & BTC & -268.00 \\
\hline \multicolumn{13}{|l|}{ (ONOSED) $650 \mathrm{C}$} \\
\hline SCHOHACHER & 4 & 1.158 & 1.158 & 2.343 & 2.342 & 1.158 & 1.178 & 2.343 & 2.382 & 0.751 & & -181.50 \\
\hline KRI 7052 & 8 & 1.140 & 1.147 & 2.355 & 2.342 & 1.144 & 1.163 & 2.349 & 2.388 & 0.760 & & -206.75 \\
\hline \multirow[t]{2}{*}{ (OSED) $650 \mathrm{C}$} & 12 & 1.130 & 1.133 & 2.349 & 2.346 & 1.132 & 1.151 & 2.348 & 2.387 & 0.759 & & -238.00 \\
\hline & 16 & 1.113 & 1.111 & 2.352 & 2.348 & 1.112 & 1.131 & 2.350 & 2.390 & 0.768 & ETC & -241.00 \\
\hline SCBOHLCHER & 4 & 1.168 & 1.169 & 2.331 & 2.338 & 1.169 & 1.188 & 2.335 & 2.374 & 0.759 & & -223.25 \\
\hline RRN 7067 & 8 & 1.143 & 1.142 & 2.343 & 2.338 & 1.143 & 1.162 & 2.341 & 2.380 & 0.763 & $\operatorname{BTC}$ & -247.50 \\
\hline \multirow[t]{2}{*}{ (USBD) $650 \mathrm{C}$} & 12 & 1.129 & 1.131 & 2.335 & 2.337 & 1.130 & 1.149 & 2.336 & 2.376 & 0.773 & $\mathrm{BTC}$ & -250.25 \\
\hline & 16 & 1.108 & 1.111 & 2.346 & 2.341 & 1.110 & 1.128 & 2.344 & 2.383 & 0.764 & HTC & -246.25 \\
\hline
\end{tabular}

BXTRA TESTING

\begin{tabular}{|c|c|c|c|c|c|c|c|c|c|c|c|}
\hline $\begin{array}{l}\text { SCHOMACHER } \\
\text { SOLAR (ONOSED) }\end{array}$ & T9 & 1.158 & 1.162 & 2.314 & 2.324 & 1.160 & 1.180 & 2.319 & 2.358 & $0.736 \mathrm{RIT}(\mathrm{B}$ & 27.00 \\
\hline $\begin{array}{l}\text { IFP LAYCER } \\
\text { (OHOSED) }\end{array}$ & 12 & 1.565 & 1.582 & 2.328 & 2.335 & 1.574 & 1.600 & 2.332 & 2.371 & $0.786 \operatorname{RTT}(\mathrm{B}$ & 45.00 \\
\hline SCHOHACHER & B13 870 & 1.146 & 1.128 & 2.348 & 2.319 & 1.137 & 1.156 & 2.334 & 2.373 & $0.748 \operatorname{BTT}(\mathrm{E}$ & 34.25 \\
\hline SOLAR (ONOSED) & $\begin{array}{l}\text { B14 } 870 \\
\text { B15 } 870\end{array}$ & 1.146 & 1.125 & 2.353 & 2.320 & 1.136 & 1.155 & 2.337 & 2.376 & $0.726 \mathrm{HLT}$ (B & 30.75 \\
\hline
\end{tabular}




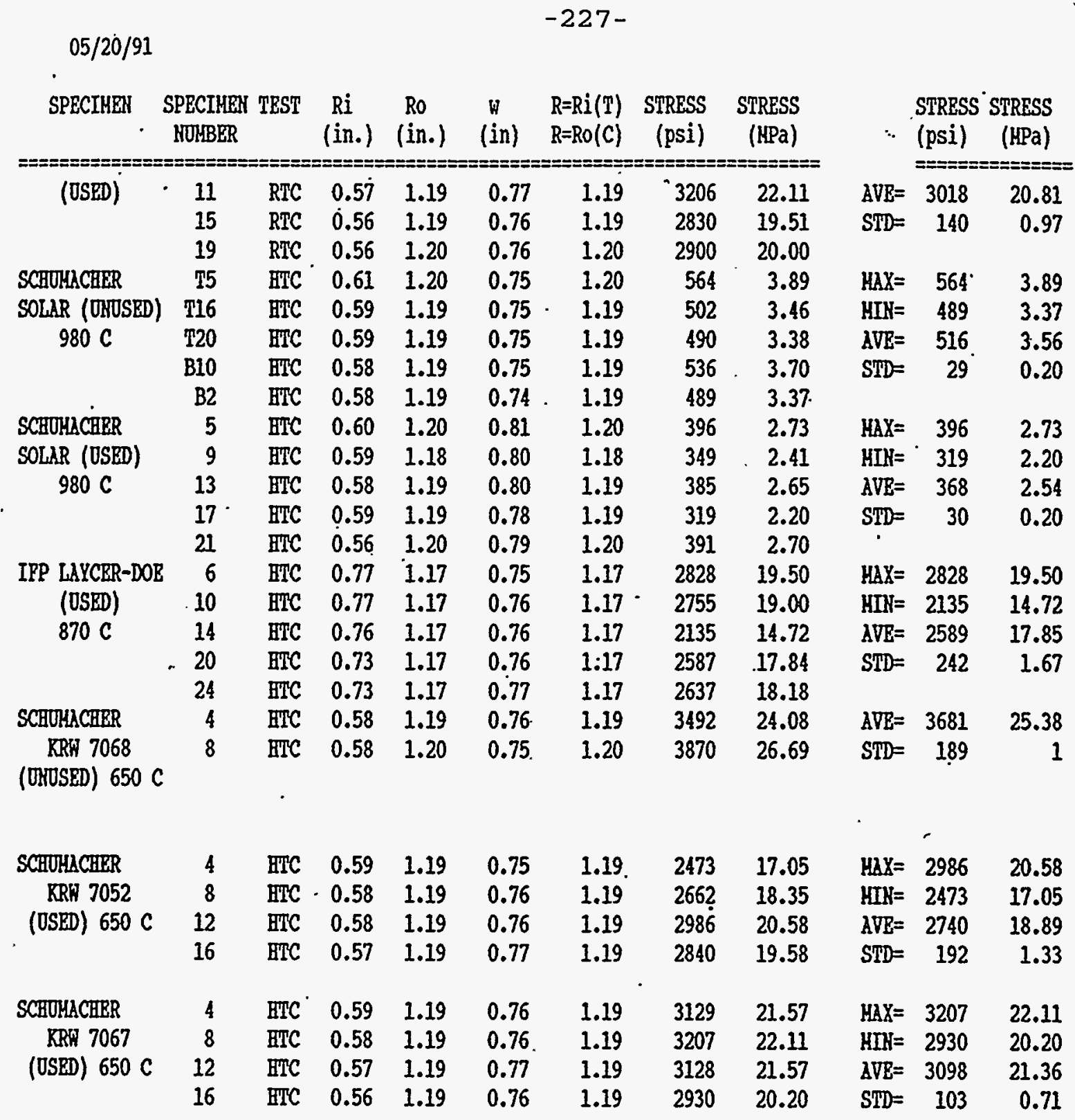

EXTRA TESTING

\begin{tabular}{|c|c|c|c|c|c|c|c|c|c|c|c|}
\hline $\begin{array}{l}\text { SCHOHACHER } \\
\text { SOLAR (ONOSED) }\end{array}$ & T9 & $\operatorname{RTT}(\mathrm{E}$ & 0.59 & 1.18 & 0.74 & 0.59 & 784 & 5.40 & & & \\
\hline $\begin{array}{l}\text { IFP LAYCER } \\
\text { (ONOSED) }\end{array}$ & 12 & $\operatorname{RTT} / \mathrm{B}$ & 0.80 & 1.19 & 0.79 & 0.80 & 2784 & 19.20 & & & \\
\hline $\begin{array}{l}\text { SCHOHACHER } \\
\text { SOLAR (ONOSED) }\end{array}$ & $\begin{array}{l}\text { B13 } \\
\text { B14 } \\
\text { B15 }\end{array}$ & 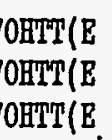 & $\begin{array}{l}0.58 \\
0.58 \\
0.58\end{array}$ & $\begin{array}{l}1.19 \\
1.19 \\
1.18\end{array}$ & $\begin{array}{l}0.75 \\
0.73 \\
0.74\end{array}$ & $\begin{array}{l}0.58 \\
0.58 \\
0.58\end{array}$ & $\begin{array}{l}927 \\
853 \\
778\end{array}$ & $\begin{array}{l}6.39 \\
5.88 \\
5.36\end{array}$ & $\begin{array}{l}A V G= \\
S T D=\end{array}$ & $\begin{array}{r}853 \\
61\end{array}$ & $\begin{array}{l}5.88 \\
0.42\end{array}$ \\
\hline
\end{tabular}


$05 / 20 / 91$

CORRECTED CORRECTED

SPECIHEN SPECIHEN I.D. 1 I.D. 2 O.D. 1 O.D. 2 AVE. I.D. I.D. AVE. O.D.' O.D. HIDTH TEST LOAD NWHBER (in.) (in.) (in.) (in.) (in.) (in.) (in.) $\because$ (in.) (in.) (lbs)

\begin{tabular}{|c|c|c|c|c|c|c|c|c|c|c|c|}
\hline & B22 925 & 1.135 & 1.157 & 2.312 & 2.341 & 1.146 & 1.165 & 2.327 & 2.366 & $0.736 \mathrm{BTT} / \mathrm{B}$ & 35.00 \\
\hline & B23 900 & 1.165 & 1.167 & 2.349 & $2.368^{\circ}$ & 1.166 & 1.186 & 2.359 & 2.398 & 0.785 ETT(B & 35.75 \\
\hline & B11 910 & 1.126 & 1.139 & 2.313 & 2.335 & 1.133 & 1.152 & 2.324 & 2.363 & 0.751 BTT(E & 36.75 \\
\hline & B12 920 & $1.147^{\circ}$ & 1.155 & 2.339 & 2.358 & 1.151 & 1.171 & 2.349 & 2.388 & 0.743 साथ & 35.75 \\
\hline & T21 925 & 1.151 & 1.161 & 2.358 & 2.342 & 1.156 & 1.176 & 2.350 & 2.390 & $0.750 \operatorname{BNT}(8$ & 38.50 \\
\hline & $T 23950$ & 1.131 & 1.133 & 2.338 & 2.317 & 1.132 & 1.151 & 2.328 & 2.367 & $0.725 \mathrm{BMT}(\mathrm{B}$ & 28.25 \\
\hline & T22 980 & 1.147 & 1.150 & 2.358 & 2.345 & 1.149 & 1.168 & 2.352 & 2.391 & 0.756 BITT(B & 21.75 \\
\hline 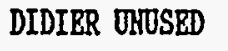 & 1980 & 1.511 & 1.505 & 2.354 & 2.346 & 1.508 & 1.534 & 2.350 & 2.390 & $0.776 \mathrm{BIT}(\mathrm{B}$ & 14.00 \\
\hline 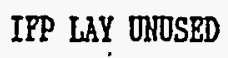 & 1980 & 1.578 & 1.576 & 2.311 & 2.308 & 1.577 & 1.604 & 2.310 & 2.349 & $0.761 \mathrm{BTT}(\mathrm{B}$ & 14.75 \\
\hline
\end{tabular}


$05 / 20 / 91$

SPECIHEN SPECIHEN TEST Ri RO $\mathrm{R}$ R $\quad$ Ri(T) STRESS STRESS $\quad$ STRESS STRESS

WUMBER (in.) (in.) (in) $\mathrm{R}=\mathrm{Ro}(\mathrm{C}) \quad$ (psi) (MPa) $\quad$ (psi) (MPa)

\begin{tabular}{|c|c|c|c|c|c|c|}
\hline B22 925HTT(B & 0.58 & 1.18 & 0.74 & 0.58 & 985 & 6.79 \\
\hline B23 900НTTT(B & 0.59 & 1.20 & 0.79 & 0.59 & 936 & 6.46 \\
\hline BII 910HTT/E & 0.58 & 1.18 & 0.75 & 0.58 & 995 & 6.86 \\
\hline $\mathrm{B12} 920 \mathrm{HLT}$ (B & 0.59 & 1.19 & 0.74 & 0.59 & 978 & 6.74 \\
\hline $\mathrm{T} 21$ 925 $\mathrm{HTT}(\mathrm{B}$ & 0.59 & 1.19 & 0.75 & 0.59 & 1050 & 7.24 \\
\hline T23 950HTT(B & 0.58 & 1.18 & 0.73 & 0.58 & 789 & 5.44 \\
\hline T22 980HTT/B & 0.58 & 1.20 & 0.76 & 0.58 & 581 & 4.00 \\
\hline
\end{tabular}

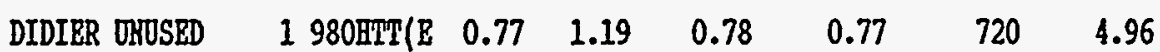

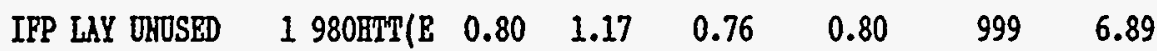


$-230-$

This Page Intentionally Left Blank 
$-231-$

APPENDIX D

C-RING TESTING DATA

D-1 
This Page Intentionally Left Blank 
05/01/93 VARYING WIDTH TESTS OF SCHUMACHER

schvrywd

\begin{tabular}{|c|c|c|c|c|c|c|c|c|c|c|c|c|c|c|}
\hline & $\begin{array}{l}\text { SPECIMEN } \\
\text { NUMBER }\end{array}$ & $\begin{array}{l}\text { ID } 1 \\
\text { in. }\end{array}$ & $\begin{array}{l}\text { ID } 2 \\
\text { in. }\end{array}$ & $\begin{array}{l}O D 1 \\
\text { in. }\end{array}$ & $\begin{array}{c}\text { OD } 2 \\
\text { in. }\end{array}$ & $\begin{array}{l}\text { WIDTH } \\
\text { in. }\end{array}$ & TEST & $\begin{array}{c}\text { ABS } \\
\text { LOAD } \\
\text { lb }\end{array}$ & $\underset{\mathrm{lb}}{\mathrm{LOAD}}$ & $\begin{array}{c}----F \\
\text { STRESS } \\
\text { psi }\end{array}$ & $\begin{array}{l}\text { ERBERE } \\
\text { STRESS } \\
\mathrm{MPa}\end{array}$ & QUATION- & ---- & \begin{tabular}{|c|} 
Small \\
Sample \\
Standard \\
Deviation \\
\end{tabular} \\
\hline \multirow{5}{*}{ 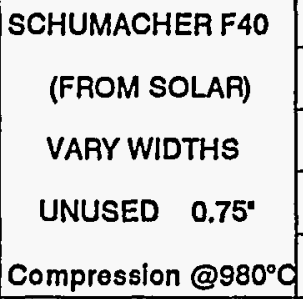 } & 5 & 1.137 & 1.166 & 2.340 & 2.376 & 0.744 & HTC & 30.5 & -30.5 & 410 & 2.82 & \multirow{2}{*}{\multicolumn{2}{|c|}{$\begin{array}{ll}\text { Ave } \mathrm{MPa}= & 3.44 \\
\mathrm{STD}= & 0.31\end{array} \mid$}} & \\
\hline & 13 & 1.136 & 1.150 & 2.371 & 2.334 & 0.753 & HTC & 41 & -41 & 538 & 3.71 & & & 0.35 \\
\hline & 21 & 1.110 & 1.105 & 2.378 & 2.333 & 0.792 & HTC & 45 & -45 & 513 & 3.54 & \multirow{3}{*}{\multicolumn{2}{|c|}{$\begin{array}{ll}\text { Ave Width } & 0.770 \\
\text { STD }= & 0.019 \\
\end{array}$}} & \\
\hline & 29 & 1.096 & 1.092 & 2.385 & 2.365 & 0.771 & HTC & 47 & -47 & 518 & 3.57 & & & \\
\hline & 35 & 1.095 & 1.091 & 2.364 & 2.386 & 0.791 & HTC & 48 & -48 & 514 & 3.55 & & & 0.022 \\
\hline \multirow{5}{*}{$\begin{array}{l}\text { SCHUMACHER F40 } \\
\text { (FROM SOLAR) } \\
\text { VARY WIDTHS } \\
\text { UNUSED } 0.50^{\circ} \\
\text { Compression @980 } \mathrm{C}\end{array}$} & 6 & 1.150 & 1.132 & 2.346 & 2.353 & 0.480 & HTC & 21 & -21 & 432 & 2.98 & \multicolumn{2}{|c|}{$\begin{array}{ll}\text { Ave MPa }= & 3.28 \\
\text { STD }= & 0.39 \\
\text { Ave Width } & 0.505 \\
\text { STD }= & 0.016\end{array}$} & \\
\hline & 14 & 1.148 & 1.164 & 2.370 & 2.335 & 0.503 & HTC & 22 & -22 & 446 & 3.07 & & & 0.43 \\
\hline & 22 & 1.124 & 1.112 & 2.376 & 2.330 & 0.500 & HTC & 28.5 & -28.5 & 530 & 3.65 & & & \\
\hline & 30 & 1.101 & 1.106 & 2.386 & 2.340 & 0.530 & HTC & 25 & -25 & 417 & 2.88 & & & \\
\hline & 36 & 1.102 & 1.105 & 2.390 & 2.363 & 0.514 & HTC & 33 & -33 & 556 & 3.84 & & & 0.018 \\
\hline \multirow{5}{*}{$\begin{array}{c}\text { SCHUMACHER F40 } \\
\text { (FROM SOLAR) } \\
\text { VARY WIDTHS } \\
\text { UNUSED } 0.75^{\prime} \\
\text { Compression @8700 }\end{array}$} & 7 & 1.166 & 1.147 & 2.377 & 2.348 & 0.733 & HTC & 59.5 & -59.5 & 815 & 5.62 & \multirow{5}{*}{\multicolumn{2}{|c|}{$\left|\begin{array}{ll}\text { Ave MPa }= & 5.68 \\
\text { STD }= & 0.34 \\
\text { Ave Width } & 0.738 \\
\text { STD }= & 0.005\end{array}\right|$}} & \\
\hline & 15 & 1.142 & 1.336 & 2.343 & 2.382 & 0.744 & HTC & 54.5 & -54.5 & 899 & 6.20 & & & 0.40 \\
\hline & 23 & 1.134 & 1.130 & 2.384 & 2.345 & 0.743 & HTC & 64.5 & -64.5 & 819 & 5.65 & & & \\
\hline & 31 & 1.119 & 1.076 & 2.388 & 2.341 & 0.733 & HTC & 64 & -64 & 760 & 5.24 & & & \\
\hline & & & & & & & HTC & & & & & & & 0.006 \\
\hline \multirow{11}{*}{\begin{tabular}{|} 
SCHUMACHER F40 \\
(FROM SOLAR) \\
VARY WIDTHS \\
UNUSED $0.50^{\prime}$ \\
Comprossion @870 \\
\end{tabular}} & 8 & 1.142 & 1.108 & 2.368 & 2.329 & 0.495 & HTC & 21 & -21 & 404 & 2.78 & \multirow{5}{*}{\multicolumn{2}{|c|}{$\begin{array}{l}\text { Ave MPa }=4.36 \\
\text { STD }=0.95 \\
\text { Ave Width } 0.510 \\
\text { STD }=0.010\end{array}$}} & \\
\hline & 16 & 1.138 & 1.135 & 2.349 & 2.369 & 0.509 & HTC & 35 & -35 & 662 & 4.56 & & & 1.10 \\
\hline & 24 & 1.113 & 1.109 & 2.330 & 2.354 & 0.519 & HTC & 38.5 & -38.5 & 690 & 4.76 & & & \\
\hline & 32 & 1.102 & 1.106 & 2.341 & 2.379 & 0.518 & HTC & 45 & -45 & 773 & 5.33 & & & \\
\hline & & & & & & & HTC & & & & & & & 0.011 \\
\hline & & & & & & & & & & & & & & \\
\hline & & & & & & & $\mathrm{RTT}$ & & 0 & ERR & ERR & \multirow{5}{*}{$\begin{array}{l}\text { Ave MPa }= \\
\text { STD }= \\
\text { Ave Width } \\
\text { STD }=\end{array}$} & \multirow{2}{*}{$\begin{array}{l}\text { ERR } \\
\text { ERR }\end{array}$} & \\
\hline & & & & & & & RTT & & 0 & ERR & ERR & & & ERR \\
\hline & & & & & & & RTT & & 0 & ERR & ERR & & \multirow[b]{2}{*}{ ERR } & \\
\hline & & & & & & & RTT & & 0 & ERR & ERA & & & \\
\hline & & & & & & & RT & & 0 & ERR & ERR & & ERR & ERR \\
\hline & & & & & & & & & & & & & & \\
\hline & & & & & & & RTT & & 0 & ERR & ERR & Ave $\mathrm{MPa}=$ & ERR & \\
\hline & & & & & & & $\mathrm{RTT}$ & & 0 & ERR & ERR & STD $=$ & ERR & ERR \\
\hline & & & & & & & RTT & & 0 & ERR & ERR & & & \\
\hline & & & & & & & RTT & & 0 & ERR & ERR & Ave Width & ERR & \\
\hline & & & & & & & RTT & & 0 & ERR & ERR & STD $=$ & ERR & ERR \\
\hline
\end{tabular}


05/01/93

schurywd

\begin{tabular}{|c|c|c|c|c|c|c|c|c|c|c|c|c|c|c|}
\hline & $\begin{array}{l}\text { SPECIMEN } \\
\text { NUMBER }\end{array}$ & $\begin{array}{l}\text { ID } 1 \\
\text { in. }\end{array}$ & $\begin{array}{l}\text { ID } 2 \\
\text { in. }\end{array}$ & $\begin{array}{l}O D 1 \\
\text { in. }\end{array}$ & $\begin{array}{l}O D 2 \\
\text { in. }\end{array}$ & $\begin{array}{l}\text { WIDTH } \\
\text { in. }\end{array}$ & TEST & $\begin{array}{l}\text { ABS } \\
\text { LOAD } \\
\text { lb }\end{array}$ & $\underset{\mathrm{Ib}}{\text { LOAD }}$ & $\begin{array}{c}---\overline{-F} \\
\text { STRESS's } \\
\text { psi }\end{array}$ & $\begin{array}{l}\text { ERBERE } \\
\text { STRESS } \\
\mathrm{MPa}\end{array}$ & QUATION- & -- & \begin{tabular}{|c|} 
Small \\
Sample \\
Standard \\
Deviation \\
\end{tabular} \\
\hline \multirow{5}{*}{$\begin{array}{l}\text { SCHUMACHER F40 } \\
\text { (FROM SOLAR) } \\
\text { VARY WIDTHS } \\
\text { UNUSED } 0.75^{\prime} \\
\text { Tonsion @ } 980^{\circ} \mathrm{C}\end{array}$} & 1 & 1.145 & 1.151 & 2.351 & 2.331 & 0.788 & $H T T$ & 20 & 20 & 527 & 3.63 & \multirow{4}{*}{\multicolumn{2}{|c|}{$\begin{array}{l}\text { Ave } \mathrm{MPa}=4.60 \\
\text { STD }=\quad 1.52\end{array}$}} & \\
\hline & 9 & 1.120 & 1.131 & 2.354 & 2.332 & 0.768 & $\mathrm{HTT}$ & 22 & 22 & 573 & 3.95 & & & 1.75 \\
\hline & 17 & 1.470 & 1.183 & 2.369 & 2.341 & 0.791 & $\mathrm{HTT}$ & 30 & 30 & 1047 & 7.22 & & & \\
\hline & 25 & 1.200 & 1.111 & 2.335 & 2.383 & 0.789 & $H T T$ & 20 & 20 & 521 & 3.59 & & & \\
\hline & 33 & 1.090 & 1.103 & 2.368 & 2.346 & 0.752 & $\mathrm{HTT}$ & & BROKE & DURING & INST. & \multicolumn{2}{|c|}{$\begin{array}{ll}\text { Ave Width } & 0.778 \\
\text { STD }= & 0.015\end{array}$} & 0.018 \\
\hline \multirow{5}{*}{$\begin{array}{l}\text { SCHUMACHER F40 } \\
\text { (FROM SOLAR) } \\
\text { VARY WIDTHS } \\
\text { UNUSED } 0.50^{\circ} \\
\text { TEnsion @ } 980^{\circ} \mathrm{C}\end{array}$} & 2 & 1.164 & 1.134 & 2.390 & 2.348 & 0.509 & $\mathrm{HTT}$ & 14.5 & 14.5 & 573 & 3.95 & \multirow{4}{*}{\multicolumn{2}{|c|}{$\begin{array}{ll}\text { Ave } \mathrm{MPa}= & 4.32 \\
\mathrm{STD}= & 0.40\end{array}$}} & \\
\hline & 10 & 1.160 & 1.121 & 2.388 & 2.353 & 0.511 & $\mathrm{HTT}$ & 17.5 & 17.5 & 679 & 4.68 & & & 0.46 \\
\hline & 18 & 1.128 & 1.122 & 2.367 & 2.329 & 0.492 & $\mathrm{HTT}$ & 17 & 17 & 687 & 4.74 & & & \\
\hline & 26 & 1.214 & 1.091 & 2.361 & 2.343 & 0.512 & $\mathrm{HTT}$ & 14 & 14 & 564 & 3.89 & & & \\
\hline & 34 & 1.102 & 1.095 & 2.385 & 2.236 & 0.530 & $H \pi$ & & BROKE & DURRINE & G INST. & STD $=$ & $\begin{array}{l}0.511 \\
0.012\end{array}$ & 0.014 \\
\hline \multirow{5}{*}{$\begin{array}{l}\text { SCHUMACHER F40 } \\
\text { (FROM SOLAR) } \\
\text { VARY WIDTHS } \\
\text { UNUSED } 0.75^{*} \\
\text { TEnsion @870 C }\end{array}$} & 3 & 1.165 & 1.143 & 2.362 & 2.337 & 0.743 & $\mathrm{HTT}$ & 34 & 34 & 949 & 6.55 & \multirow{5}{*}{\multicolumn{2}{|c|}{ 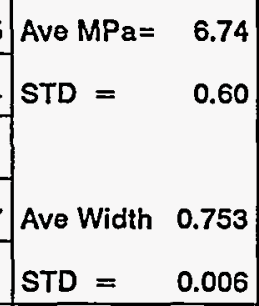 }} & \\
\hline & 11 & 1.162 & 1.142 & 2.331 & 2.372 & 0.758 & $\mathrm{HTT}$ & 37 & 37 & 1007 & 6.94 & & & 0.69 \\
\hline & 19 & 1.122 & 1.119 & 2.378 & 2.356 & 0.755 & HIT & 33.5 & 33.5 & 858 & 5.91 & & & \\
\hline & 27 & 1.223 & 1.191 & 2.387 & 2.342 & 0.757 & $\mathrm{HTT}$ & 37.5 & 37.5 & 1097 & 7.57 & & & \\
\hline & & & & & & & $\mathrm{HTT}$ & & & & & & & 0.007 \\
\hline \multirow{5}{*}{$\begin{array}{l}\text { SCHUMACHER F40 } \\
\text { (FROM SOLAR) } \\
\text { VARY WIDTHS } \\
\text { UNUSED } 0.50^{\circ} \\
\text { Tension @870 }\end{array}$} & 4 & 1.135 & 1.143 & 2.335 & 2.341 & 0.495 & $\mathrm{HTT}$ & 20.5 & 20.5 & 851 & 5.87 & \multirow{5}{*}{\multicolumn{2}{|c|}{ 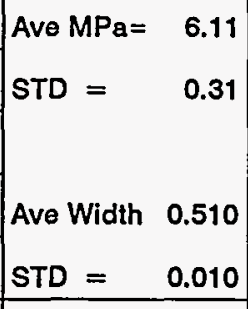 }} & \\
\hline & 12 & 1.136 & 1.142 & 2.345 & 2.330 & 0.518 & $\mathrm{HTT}$ & 21 & 21 & 833 & 5.75 & & & 0.36 \\
\hline & 20 & 1.128 & 1.137 & 2.386 & 2.372 & 0.505 & $\mathrm{HTT}$ & 24 & 24 & 922 & 6.36 & & & \\
\hline & 28 & 1.127 & 1.102 & 2.397 & 2.341 & 0.520 & $H T T$ & 25.5 & 25.5 & 937 & 6.46 & & & \\
\hline & & & & & & & $\mathrm{HTT}$ & & & & & & & 0.012 \\
\hline & & & & & & & & & & & & \multirow{4}{*}{$\begin{array}{l}\text { Ave MPa }= \\
\text { STD }=\end{array}$} & \multirow{4}{*}{$\begin{array}{l}\text { ERR } \\
\text { ERR }\end{array}$} & \\
\hline & & & & & & & RTC & & 0 & ERA & ERR & & & \\
\hline & & & & & & & RTC & & 0 & ERR & ERR & & & ERR \\
\hline & & & & & & & RTC & & 0 & ERR & ERR & & & \\
\hline & & & & & & & RTC & & 0 & ERR & ERR & \multirow{2}{*}{$\begin{array}{l}\text { Ave Width } \\
\text { STD = }\end{array}$} & \multirow{2}{*}{$\begin{array}{l}\text { ERR } \\
\text { ERR } \\
\end{array}$} & \\
\hline & & & & & & & RTC & & 0 & ERR & ERR & & & ERR \\
\hline & & & & & & & & & & & & \multirow{4}{*}{$\begin{array}{l}\text { Ave MPa= } \\
\text { STD }=\end{array}$} & \multirow{3}{*}{$\begin{array}{l}\text { ERR } \\
\text { ERR }\end{array}$} & \\
\hline & & & & & & & RTC & & 0 & ERR & ERR & & & \\
\hline & & & & & & & RTC & & 0 & ERR & ERR & & & ERR \\
\hline & & & & & & & RTC & & 0 & ERR & ERR & & \multirow{3}{*}{\begin{tabular}{l|} 
ERR \\
ERR
\end{tabular}} & \\
\hline & & & & & & & RTC & & 0 & ERR & ERR & \multirow{2}{*}{$\begin{array}{l}\text { Ave Width } \\
\text { STD }=\end{array}$} & & \\
\hline & & & & & & & RTC & & 0 & ERR & ERR & & & ERR \\
\hline
\end{tabular}


02/25/93 $505 \mathrm{vrywd}$

\begin{tabular}{|c|c|c|c|c|c|c|c|c|c|c|c|c|c|c|}
\hline & $\begin{array}{l}\text { SPECIMEN } \\
\text { NUMBER }\end{array}$ & $\begin{array}{l}\text { ID } 1 \\
\text { in. }\end{array}$ & $\begin{array}{l}\text { ID } 2 \\
\text { in. }\end{array}$ & $\begin{array}{l}\text { OD } 1 \\
\text { in. }\end{array}$ & $\begin{array}{c}O D 2 \\
\text { in. }\end{array}$ & $\begin{array}{c}\text { WIDTH } \\
\text { in. }\end{array}$ & TEST & $\begin{array}{c}\text { ABS } \\
\text { LOAD } \\
\text { lb }\end{array}$ & $\underset{\text { lb }}{\operatorname{LOAD}}$ & $\begin{array}{c}\text { PTRESS } \\
\text { psi }\end{array}$ & $\begin{array}{l}\text { ERBER } \\
\text { STRESS } \\
\text { MPa }\end{array}$ & QUATION- & ---- & \begin{tabular}{|c|} 
Small \\
Sample \\
Standard \\
Deviation \\
\end{tabular} \\
\hline \multirow{5}{*}{$\begin{array}{l}\text { REFRACTRON 50/5 } \\
\text { WITH } 505 \text { BINDER } \\
\text { VARY WIDTHS } \\
0.50^{*} \\
\text { UNUSED \#8 }\end{array}$} & 2 & 1.593 & 1.581 & 2.347 & 2.337 & 0.508 & RTT & 20.2 & 20.2 & 1990 & 13.72 & \multirow{5}{*}{\multicolumn{2}{|c|}{$\begin{array}{l}\text { Ave MPa }=14.47 \\
\text { STD }= \\
\text { Ave Width } 0.490 \\
\text { STD }=0.40\end{array}$}} & \\
\hline & 13 & 1.563 & 1.559 & 2.337 & 2.343 & 0.482 & RTT & 21.7 & 21.7 & 2118 & 14.60 & & & 1.57 \\
\hline & 23 & 1.575 & 1.579 & 2.368 & 2.377 & 0.475 & RTT & 18.4 & 18.4 & 1772 & 12.22 & & & \\
\hline & 33 & 1.568 & 1.573 & 2.364 & 2.370 & 0.510 & RTT & 26.3 & 26.3 & 2348 & 16.19 & & & \\
\hline & 43 & 1.534 & 1.532 & 2.339 & 2.342 & 0.475 & RTT & 24.5 & 24.5 & 2262 & 15.59 & & & 0.018 \\
\hline \multirow{5}{*}{$\begin{array}{l}\text { REFRACTRON 50/5 } \\
\text { WITH } 505 \text { BINDER } \\
\text { VARY WIDTHS } \\
0.75^{*} \\
\text { UNUSED \#8 }\end{array}$} & 3 & 1.583 & 1.591 & 2.343 & 2.352 & 0.740 & RTT & 30.4 & 30.4 & 2032 & 14.01 & \multirow{5}{*}{\multicolumn{2}{|c|}{ 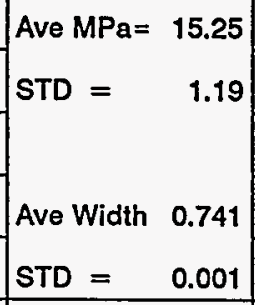 }} & \\
\hline & 14 & 1.570 & 1.562 & 2.350 & 2.346 & 0.742 & RTT & 32.7 & 32.7 & 2064 & 14.23 & & & 1.34 \\
\hline & 24 & 1.541 & 1.545 & 2.334 & 2.334 & 0.743 & RTT & 35.5 & 35.5 & 2176 & 15.00 & & & \\
\hline & 34 & 1.543 & 1.533 & 2.339 & 2.332 & 0.739 & RTT & 41.4 & 41.4 & 2512 & 17.32 & & & \\
\hline & 44 & 1.550 & 1.544 & 2.349 & 2.349 & 0.740 & RTT & 37.8 & 37.8 & 2278 & 15.71 & & & 0.002 \\
\hline \multirow{5}{*}{$\begin{array}{l}\text { REFRACTRON } 50 / 5 \\
\text { WITH } 505 \text { BINDER } \\
\text { VARY WIDTHS } \\
1.00 " \\
\text { UNUSED \#8 }\end{array}$} & 5 & 1.558 & 1.560 & 2.320 & 2.321 & 1.121 & $R T$ & 49.5 & 49.5 & 2154 & 14.85 & \multirow{5}{*}{\multicolumn{2}{|c|}{ 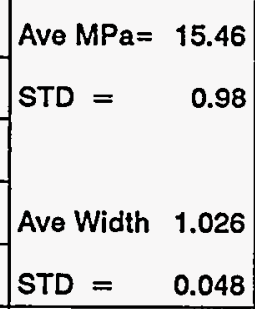 }} & \\
\hline & 15 & 1.559 & 1.559 & 2.342 & 2.342 & 1.001 & RTT & 47.0 & 47 & 2188 & 15.09 & & & 1.09 \\
\hline & 25 & 1.545 & 1.545 & 2.335 & 2.335 & 0.990 & $\mathrm{RTT}$ & 50.4 & 50.4 & 2325 & 16.03 & & & \\
\hline & 35 & 1.546 & 1.533 & 2.337 & 2.330 & 1.019 & RTT & 46.7 & 46.7 & 2071 & 14.28 & & & \\
\hline & 45 & 1.529 & 1.533 & 2.330 & 2.334 & 1.001 & RTT & 55.8 & 55.8 & 2475 & 17.06 & & & 0.054 \\
\hline \multirow{5}{*}{$\begin{array}{l}\text { REFRACTRON 50/5 } \\
\text { WITH } 505 \text { BINDER } \\
\text { VARY WIDTHS } \\
1.25^{*} \\
\text { UNUSED \#8 }\end{array}$} & 6 & 1.557 & 1.564 & 2.321 & 2.332 & 1.277 & RT & 62.7 & 62.7 & 2374 & 16.37 & \multirow{5}{*}{\multicolumn{2}{|c|}{ 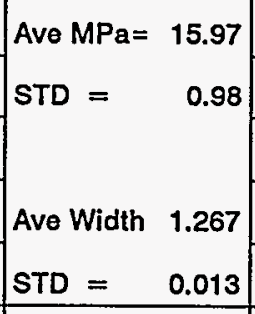 }} & \\
\hline & 16 & 1.570 & 1.577 & 2.358 & 2.364 & 1.254 & RTT & 56.9 & 56.9 & 2107 & 14.53 & & & 1.10 \\
\hline & 26 & 1.571 & 1.560 & 2.367 & 2.356 & 1.288 & RTT & 62.0 & 62 & 2190 & 15.10 & & & \\
\hline & 36 & 1.559 & 1.553 & 2.356 & 2.351 & 1.259 & RT & 69.0 & 69 & 2476 & 17.07 & & & \\
\hline & 46 & 1.530 & 1.539 & 2.334 & 2.344 & 1.256 & RTT & 69.2 & 69.2 & 2432 & 16.77 & & & 0.015 \\
\hline \multirow{10}{*}{$\begin{array}{l}\text { REFRACTRON } 50 / 5 \\
\text { WITH } 505 \text { BINDER } \\
\text { HEAT TREATED } \\
\text { TO } 980^{\circ} \mathrm{C}\left(0.50^{\circ}\right) \\
\text { UNUSED \#8 }\end{array}$} & 1 & 1.571 & 1.571 & 2.322 & 2.323 & 0.490 & RTा & 18.4 & 18.4 & 1882 & 12.97 & \multicolumn{2}{|c|}{$\begin{array}{ll}\text { Ave MPa }= & 12.91 \\
\text { STD }= & 0.46 \\
\text { Ave Width } & 0.491 \\
\text { STD }= & 0.016\end{array}$} & \\
\hline & 12 & 1.562 & 1.570 & 2.340 & 2.347 & 0.513 & RTT & 19.3 & 19.3 & 1779 & 12.26 & & & 0.51 \\
\hline & 22 & 1.567 & 1.575 & 2.359 & 2.368 & 0.495 & RTT & 19.6 & 19.6 & 1818 & 12.54 & & & \\
\hline & 32 & 1.534 & 1.539 & 2.332 & 2.341 & 0.493 & RTT & 21.3 & 21.3 & 1926 & 13.28 & & & \\
\hline & 42 & 1.533 & 1.532 & 2.337 & 2.337 & 0.464 & RTT & 20.6 & 20.6 & 1958 & 13.50 & & & 0.018 \\
\hline & & & & & & & RTT & & 0 & 요 & 0.00 & Ave $\mathrm{MPa}=$ & 0.00 & \\
\hline & & & & & & & RTT & & 0 & 0 & 0.00 & STD $=$ & 0.00 & 0.00 \\
\hline & & & & & & & RTT & & 0 & 0 & 0.00 & & & \\
\hline & & & & & & & RTT & & 0 & 0 & 0.00 & Ave Width & 0.478 & \\
\hline & & & & & & & RTT & & 0 & 0 & 0.00 & & 0.005 & 0.006 \\
\hline
\end{tabular}


02/25/93 VARYING WIDTH TESTS FROM 0.50" TO 1.25"

505vrywd

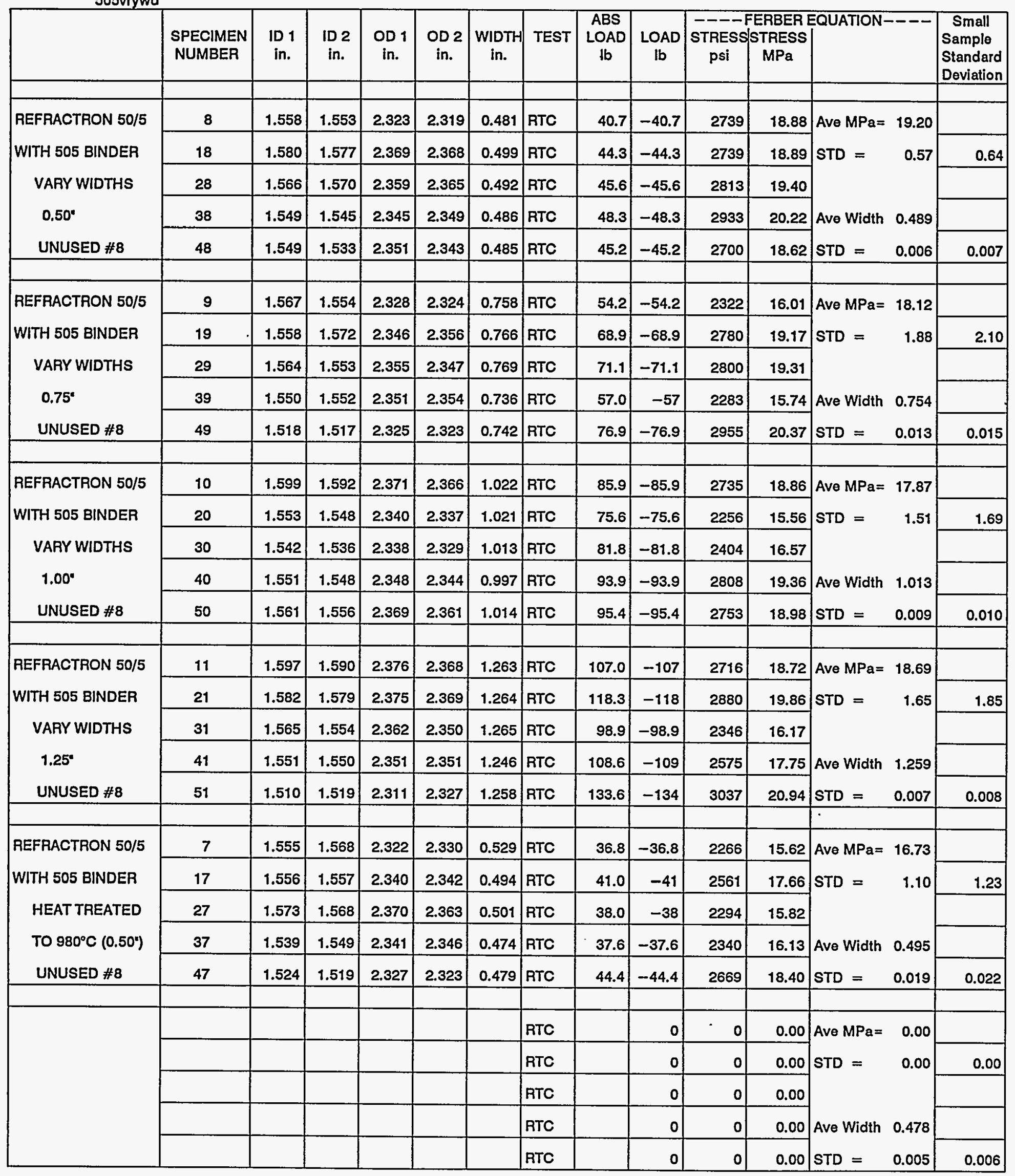


05/01/93

703vrywd

UNUSED REFRACTRON 70/3 w/442-T BINDER

VARYING WIDTH TESTS

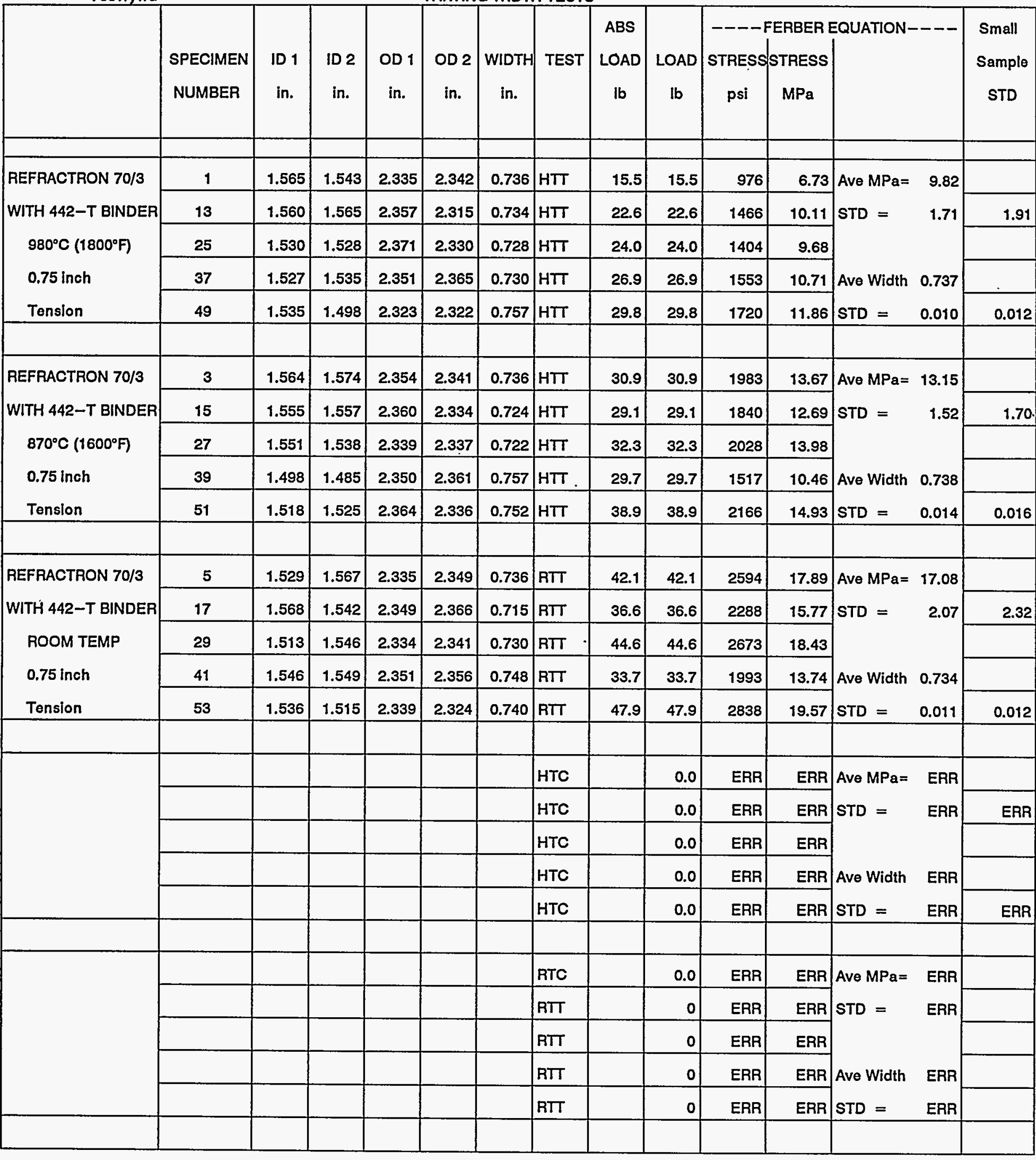


05/01/93

703vrywd

\section{UNUSED REFRACTRON 70/3 w/442-T BINDER}

VARYING WIDTH TESTS

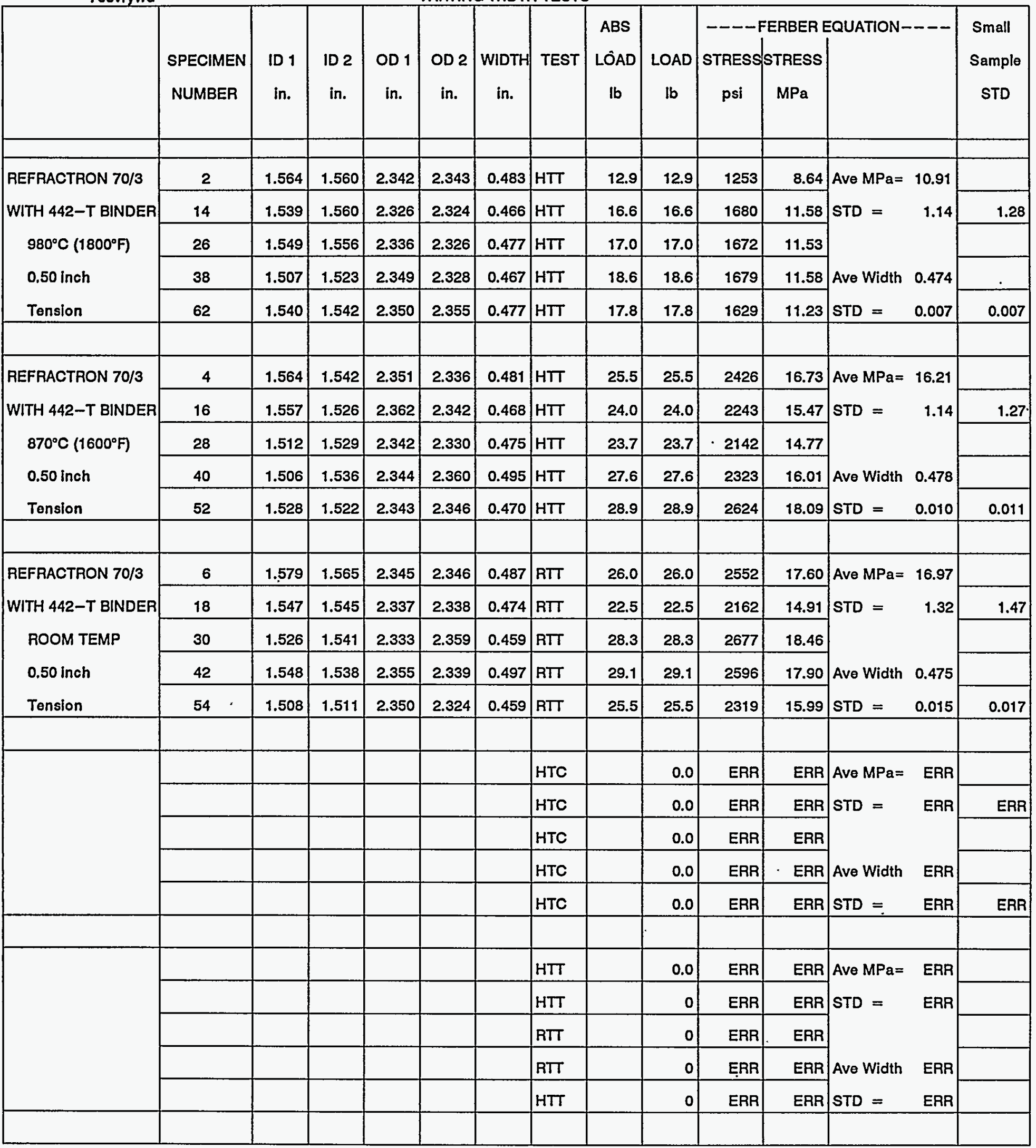


05/01/93

703 vrywd

\section{VARYING WIDTH TESTS}

\begin{tabular}{|c|c|c|c|c|c|c|c|c|c|c|c|c|c|c|}
\hline & $\begin{array}{l}\text { SPECIMEN } \\
\text { NUMBER }\end{array}$ & $\begin{array}{l}\text { ID } 1 \\
\text { in. }\end{array}$ & $\begin{array}{l}\text { ID } 2 \\
\text { in. }\end{array}$ & $\begin{array}{l}O D 1 \\
\text { in. }\end{array}$ & $\begin{array}{l}\text { OD } 2 \\
\text { in. }\end{array}$ & $\begin{array}{c}\text { WIDTH } \\
\text { in. }\end{array}$ & TEST & $\begin{array}{c}\text { ABS } \\
\text { LOAD } \\
\text { lb }\end{array}$ & $\begin{array}{c}\text { LOAD } \\
\text { Ib }\end{array}$ & $\begin{array}{c}--- \\
\text { STRESS } \\
\text { psi }\end{array}$ & $\begin{array}{l}\text { ERBER } \\
\text { TRESS } \\
\mathrm{MPa}\end{array}$ & QUATION- & --- & $\begin{array}{l}\text { Small } \\
\text { Sample } \\
\text { STD }\end{array}$ \\
\hline REFRACTRON 70/3 & 7 & 1.562 & 1.537 & 2.344 & 2.317 & 0.726 & HTC & 25.7 & -25.7 & 1097 & 7.57 & \multicolumn{2}{|c|}{$\begin{array}{l}\text { Ave MPa }=8.19 \\
\text { STD }=0.85\end{array}$} & \\
\hline WITH 442-T BINDER & 61 & 1.478 & 1.509 & 2.330 & 2.327 & 0.776 & HTC & 29.4 & -29.4 & 993 & 6.85 & & & 0.95 \\
\hline $980^{\circ} \mathrm{C}\left(1800^{\circ} \mathrm{F}\right)$ & 31 & 1.551 & 1.541 & 2.358 & 2.352 & 0.758 & HTC & 34.6 & -34.6 & 1317 & 9.08 & \multirow{3}{*}{\multicolumn{2}{|c|}{$\begin{array}{ll}\text { Ave Width } & 0.757 \\
\text { STD }= & 0.017 \\
\end{array}$}} & \\
\hline 0.75 inch & 43 & 1.507 & 1.542 & 2.339 & 2.328 & 0.765 & HTC & 33.5 & -33.5 & 1246 & 8.59 & & & \\
\hline Compression & 55 & 1.518 & 1.517 & 2.354 & 2.352 & 0.758 & HTC & 36.7 & -36.7 & 1288 & 8.88 & & & 0.019 \\
\hline REFRACTRON 70/3 & 9 & 1.548 & 1.527 & 2.343 & 2.338 & 0.738 & HTC & 56.8 & -56.8 & 2241 & 15.45 & \multirow{2}{*}{\multicolumn{2}{|c|}{$\begin{array}{l}\text { Ave } \mathrm{MPa}=17.49 \\
\text { STD }=2.03\end{array}$}} & \\
\hline WITH 442-T BINDER & 21 & 1.556 & 1.558 & 2.343 & 2.349 & 0.717 & HTC & 60.5 & -60.5 & 2575 & 17.76 & & & 2.27 \\
\hline $870^{\circ} \mathrm{C}\left(1600^{\circ} \mathrm{F}\right)$ & 33 & 1.551 & 1.543 & 2.341 & 2.330 & 0.716 & HTC & 62.0 & -62.0 & 2630 & 18.13 & \multirow{2}{*}{\multicolumn{2}{|c|}{ Ave Width 0.729}} & \\
\hline 0.75 inch & 45 & 1.470 & 1.503 & 2.331 & 2.322 & 0.740 & HTC & 63.6 & -63.6 & 2217 & 15.28 & & & \\
\hline Compression & 57 & 1.539 & 1.527 & 2.336 & 2.331 & 0.733 & HTC & 75.8 & -75.8 & 3021 & 20.83 & STD $=$ & 0.010 & 0.012 \\
\hline REFRACTRON 70/3 & 11 & 1.530 & 1.569 & 2.332 & 2.337 & 0.731 & RTC & 68.0 & -68.0 & 2854 & 19.68 & \multirow{2}{*}{\multicolumn{2}{|c|}{ 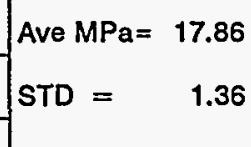 }} & \\
\hline WITH 442-T BINDER & 23 & 1.550 & 1.538 & 2.337 & 2.329 & 0.726 & RTC & 66.4 & -66.4 & 2769 & 19.09 & & & 1.52 \\
\hline ROOM TEMP & 35 & 1.527 & 1.540 & 2.344 & 2.380 & 0.702 & RTC & 66.3 & -66.3 & 2580 & 17.79 & \multirow{3}{*}{$\begin{array}{l}\text { Ave Width } \\
\text { STD = }\end{array}$} & \multirow{3}{*}{$\begin{array}{l}0.725 \\
0.012 \\
\end{array}$} & \\
\hline 0.75 Inch & 47 & 1.509 & 1.477 & 2.344 & 2.360 & 0.733 & RTC & 70.5 & -70.5 & 2384 & 16.44 & & & \\
\hline Compression & 59 & 1.496 & 1.520 & 2.324 & 2.365 & 0.735 & RTC & 66.0 & -66.0 & 2368 & 16.33 & & & 0.014 \\
\hline & & & & & & & HTC & & 0.0 & ERR & ERR & \multirow{3}{*}{$\begin{array}{l}\text { Ave MPa = } \\
\text { STD }=\end{array}$} & \multirow{2}{*}{$\begin{array}{l}\text { ERR } \\
\text { ERR }\end{array}$} & \\
\hline & & & & & & & HTC & & 0.0 & ERR & ERR & & & ERR \\
\hline & & & & & & & HTC & & 0.0 & ERR & ERR & & \multirow[b]{2}{*}{ ERR } & \\
\hline & & & & & & & HTC & & 0.0 & ERR & ERR & \multirow{2}{*}{$\begin{array}{l}\text { Ave Width } \\
\text { STD }=\end{array}$} & & \\
\hline & & & & & & & HTC & & 0.0 & ERR & ERR & & ERR & ERR \\
\hline & & & & & & & & & & & & & \\
\hline & & & & & & & RTC & & 0.0 & ERR & ERR & \multicolumn{2}{|c|}{$\begin{array}{ll}\text { Ave } \mathrm{MPa}= & \text { ERR } \\
\text { STD }= & \text { ERR }\end{array}$} & \\
\hline & & & & & & & RTC & & 0 & ERR & ERR & & & \\
\hline & & & & & & & RTC & & 0 & ERR & ERR & & & \\
\hline & & & & & & & RTC & & 0 & ERR & ERR & \multirow{2}{*}{$\begin{array}{l}\text { Ave Width } \\
\text { STD }=\end{array}$} & ERR & \\
\hline & & & & & & & RTC & & 0 & ERR & ERR & & ERR & \\
\hline & & & & & & & & & & & & & & \\
\hline
\end{tabular}


05/01/93

703vrywd

UNUSED REFRACTRON 70/3 w/442-T BINDER

VARYING WIDTH TESTS

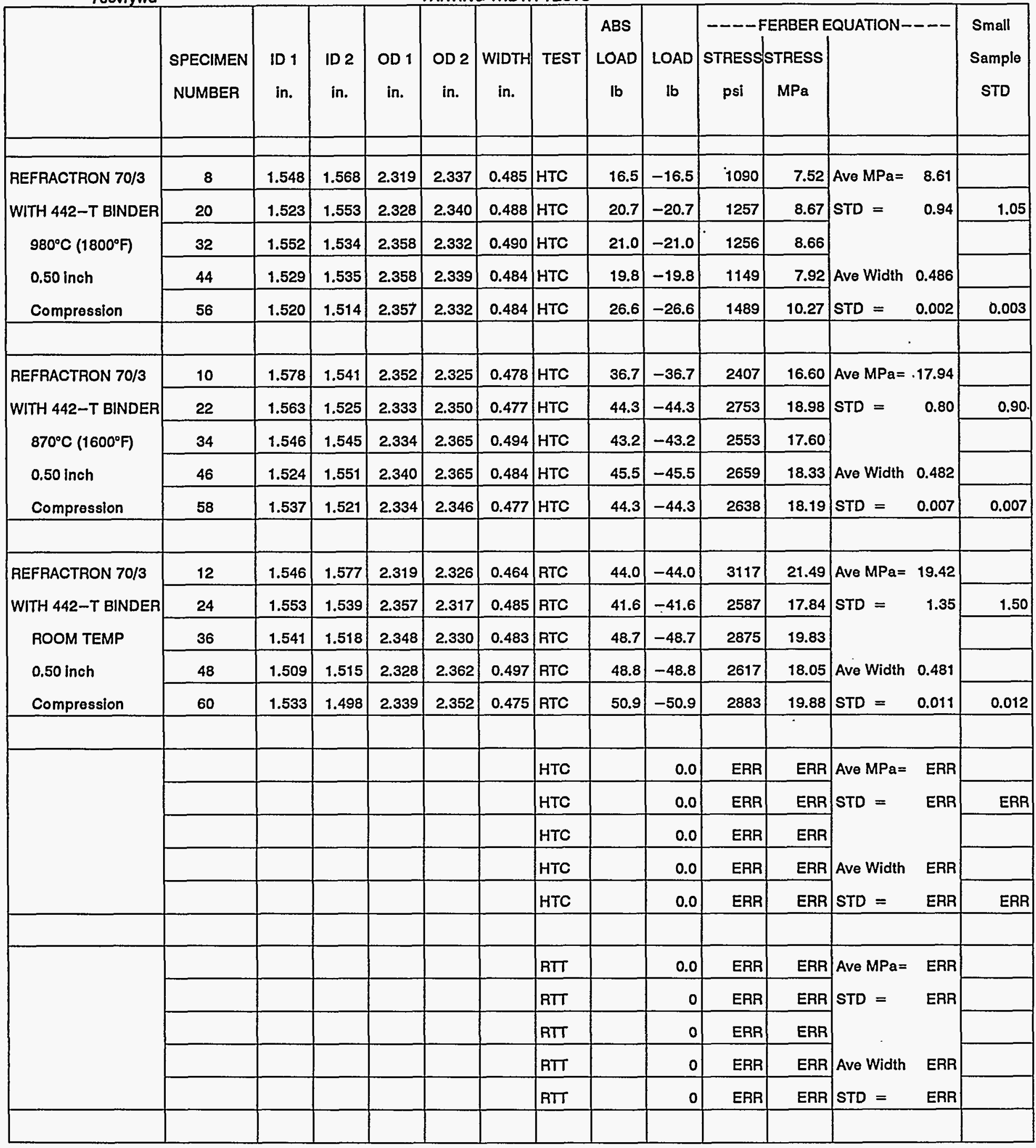


05/01/93 REFRACTRON 50/5 w/505: HEAT TREATED UNUSED \#11 505httrt $>1$ HOUR AT $1200^{\circ} \mathrm{C}$

\begin{tabular}{|c|c|c|c|c|c|c|c|c|c|c|c|c|c|c|}
\hline $\begin{array}{l}\text { PRECUT A }(1-5) \\
\text { POSTCUT A }(6-12) \\
\text { PRECUT B }(1-5) \\
\text { POSTCUT B }(6-12)\end{array}$ & $\begin{array}{l}\text { SPECIMEN } \\
\text { NUMBER }\end{array}$ & $\begin{array}{l}\text { ID } 1 \\
\text { in. }\end{array}$ & $\begin{array}{l}\text { ID } 2 \\
\text { in. }\end{array}$ & $\begin{array}{l}\text { OD } 1 \\
\text { in. }\end{array}$ & $\begin{array}{c}O D 2 \\
\text { in. }\end{array}$ & $\begin{array}{l}\text { WIDTH } \\
\text { in. }\end{array}$ & TEST & $\begin{array}{c}\text { ABS } \\
\text { LOAD } \\
\mathrm{lb}\end{array}$ & $\begin{array}{c}\text { LOAD } \\
\text { Ib }\end{array}$ & $\begin{array}{c}----F \\
\text { STRESS } \\
\text { psi }\end{array}$ & $\begin{array}{l}\text { ERBER E } \\
\text { STAESS } \\
\text { MPa }\end{array}$ & EQUATION- & --- & $\begin{array}{l}\text { Small } \\
\text { Samplo } \\
\text { STD }\end{array}$ \\
\hline REFRACTRON 50/5 & A1 & 1.536 & 1.534 & 2.362 & 2.344 & 0.729 & $\mathrm{RTT}$ & 30.9 & 30.9 & 1822 & 12.56 & \multicolumn{2}{|c|}{$\begin{array}{lr}\text { Ave } M P a= & 11.68 \\
\text { STD }= & 1.43\end{array}$} & \\
\hline WITH 505 BINDER & $A 3$ & 1.507 & 1.523 & 2.346 & 2.348 & 0.741 & RTT & 31.2 & 31.2 & 1746 & 12.04 & & & 1.60 \\
\hline UNUSED (\#11) & A5 & 1.545 & 1.515 & 2.346 & 2.360 & 0.746 & $\mathrm{RTT}$ & 31.0 & 31.0 & 1765 & 12.17 & & & \\
\hline PRECUT C-rings & $\mathrm{B} 2$ & 1.444 & 1.489 & 2.341 & 2.364 & 0.749 & RTT & 26.2 & 26.2 & 1286 & 8.87 & & & \\
\hline HEAT TO $1200^{\circ} \mathrm{C}$ & $\mathrm{B} 4$ & 1.543 & 1.515 & 2.344 & 2.351 & 0.754 & RTT & 32.6 & 32.6 & 1852 & 12.77 & & & 0.010 \\
\hline REFRACTRON 50/5 & A6 & 1.538 & 1.542 & 2.361 & 2.359 & 0.755 & RTT & 33.4 & 33.4 & 1897 & 13.08 & \multicolumn{2}{|c|}{$\begin{array}{ll}\text { Ave } M P a= & 12.52 \\
\text { STD }= & 1.39 \\
\text { Ave Width } & 0.751 \\
\text { STD }= & 0.006\end{array}$} & \\
\hline WITH 505 BINDER & A8 & 1.530 & 1.537 & 2.360 & 2.367 & 0.740 & RTT & 34.2 & 34.2 & 1939 & 13.37 & & & 1.56 \\
\hline UNUSED (\#11) & A10 & 1.535 & 1.528 & 2.362 & 2.352 & 0.756 & RTT & 34.6 & 34.6 & 1935 & 13.34 & & & \\
\hline HEAT TO $1200^{\circ} \mathrm{C}$ & B7 & 1.517 & 1.516 & 2.359 & 2.367 & 0.751 & RTT & 26.3 & 26.3 & 1413 & 9.74 & & & \\
\hline POSTCUT C-ring & B9 & 1.515 & 1.507 & 2.357 & 2.361 & 0.753 & RTT & 35.5 & 35.5 & 1893 & 13.05 & & & 0.006 \\
\hline REFRACTRON 50/5 & $\mathrm{A} 2$ & 1.509 & 1.529 & 2.343 & 2.358 & 0.728 & RTC & 49.3 & -49.3 & 1820 & 12.55 & \multicolumn{2}{|c|}{$\begin{array}{ll}\text { Ave } \mathrm{MPa}= & 13.20 \\
\text { STD }= & 0.73 \\
\text { Ave Width } & 0.740 \\
\text { STD }= & 0.012\end{array}$} & \\
\hline WITH 505 BINDER & A4 & 1.537 & 1.545 & 2.354 & 2.346 & 0.743 & RTC & 54.3 & -54.3 & 2102 & 14.49 & & & 0.81 \\
\hline UNUSED (\#11) & B1 & 1.460 & 1.540 & 2.368 & 2.335 & 0.747 & RTC & 57.0 & -57.0 & 1933 & 13.33 & & & \\
\hline PRECUT C-rings & $\mathrm{B3}$ & 1.491 & 1.503 & 2.369 & 2.347 & 0.757 & RTC & 58.4 & -58.4 & 1908 & 13.16 & & & \\
\hline HEAT TO $1200^{\circ} \mathrm{C}$ & B5 & 1.540 & 1.475 & 2.376 & 2.336 & 0.725 & RTC & 51.2 & -51.2 & 1810 & 12.48 & & & 0.013 \\
\hline REFRACTRON 50/5 & A7 & 1.518 & 1.528 & 2.353 & 2.357 & 0.741 & RTC & 52.1 & -52.1 & 1892 & 13.04 & \multicolumn{2}{|c|}{$\begin{array}{ll}\text { Ave MPa }= & 15.46 \\
\text { STD }= & 2.00 \\
\text { Ave Width } & 0.748 \\
\text { STD }= & 0.007\end{array}$} & \\
\hline WITH 505 BINDER & A9 & 1.515 & 1.537 & 2.373 & 2.358 & 0.753 & RTC & 56.7 & -56.7 & 1994 & 13.75 & & & 2.24 \\
\hline UNUSED (\#11) & 86 & 1.533 & 1.544 & 2.348 & 2.364 & 0.759 & RTC & 59.7 & -59.7 & 2213 & 15.26 & & & \\
\hline HEAT TO $1200^{\circ} \mathrm{C}$ & B8 & 1.528 & 1.539 & 2.353 & 2.362 & 0.739 & RTC & 64.6 & -64.6 & 2413 & 16.64 & & & \\
\hline POSTCUT C-ring & B10 & 1.514 & 1.524 & 2.365 & 2.347 & 0.748 & RTC & 76.1 & -76.1 & 2698 & 18.61 & & & 0.008 \\
\hline REFRACTRON 50/5 & A11 & 1.513 & 1.526 & 2.357 & 2.356 & 0.700 & HTT & 45.6 & 45.6 & 2680 & 18.48 & \multirow{5}{*}{\multicolumn{2}{|c|}{ 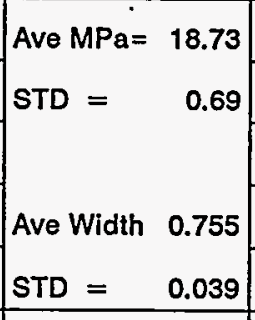 }} & \\
\hline w/505 (Unused \#11) & A12 & 1.533 & 1.545 & 2.364 & 2.381 & 0.758 & $\mathrm{HTT}$ & 52.4 & 52.4 & 2886 & 19.90 & & & 0.80 \\
\hline HEAT TO $1200^{\circ} \mathrm{C}$ & B11 & 1.493 & 1.506 & 2.356 & 2.347 & 0.751 & $\mathrm{HTT}$ & 49.7 & 49.7 & 2625 & 18.10 & & & \\
\hline POSTCUT C-ring & $\mathbf{B 1 2}$ & 1.530 & 1.523 & 2.341 & 2.364 & 0.810 & HTT & 51.4 & 51.4 & 2675 & 18.44 & & & \\
\hline $\mathrm{H} T \mathrm{~T}$ at $980^{\circ} \mathrm{C}$ & & & & & & & HTT & & & & & & & 0.045 \\
\hline REFRACTRON 50/5 & 1 & 1.499 & 1.565 & 2.314 & 2.373 & 0.477 & RTT & Load ce & Il off & & & \multicolumn{2}{|c|}{$\begin{array}{ll}\text { Ave MPa }= & 20.02 \\
\text { STD }= & 0.96 \\
\text { Ave Width } & 0.480 \\
\text { STD }= & 0.004\end{array}$} & \\
\hline w/505 (Unused \#11) & 2 & 1.493 & 1.518 & 2.329 & 2.353 & 0.484 & RTT & 35.2 & 35.2 & 2984 & 20.58 & & & 1.11 \\
\hline Refractron heated & 3 & 1.509 & 1.559 & 2.332 & 2.376 & 0.486 & $\mathrm{RTT}$ & 32.8 & 32.8 & 2888 & 19.91 & & & \\
\hline cut $\mathrm{c}-$-rngs $1200^{\circ} \mathrm{C}$ & 4 & 1.513 & 1.518 & 2.322 & 2.370 & 0.479 & RTT & 35.2 & 35.2 & 3057 & 21.08 & & & \\
\hline POSTCUT c-ring & 5 & 1.496 & 1.543 & 2.321 & 2.374 & 0.474 & $\mathrm{RTT}$ & 30.4 & 30.4 & 2685 & 18.52 & & & 0.005 \\
\hline
\end{tabular}




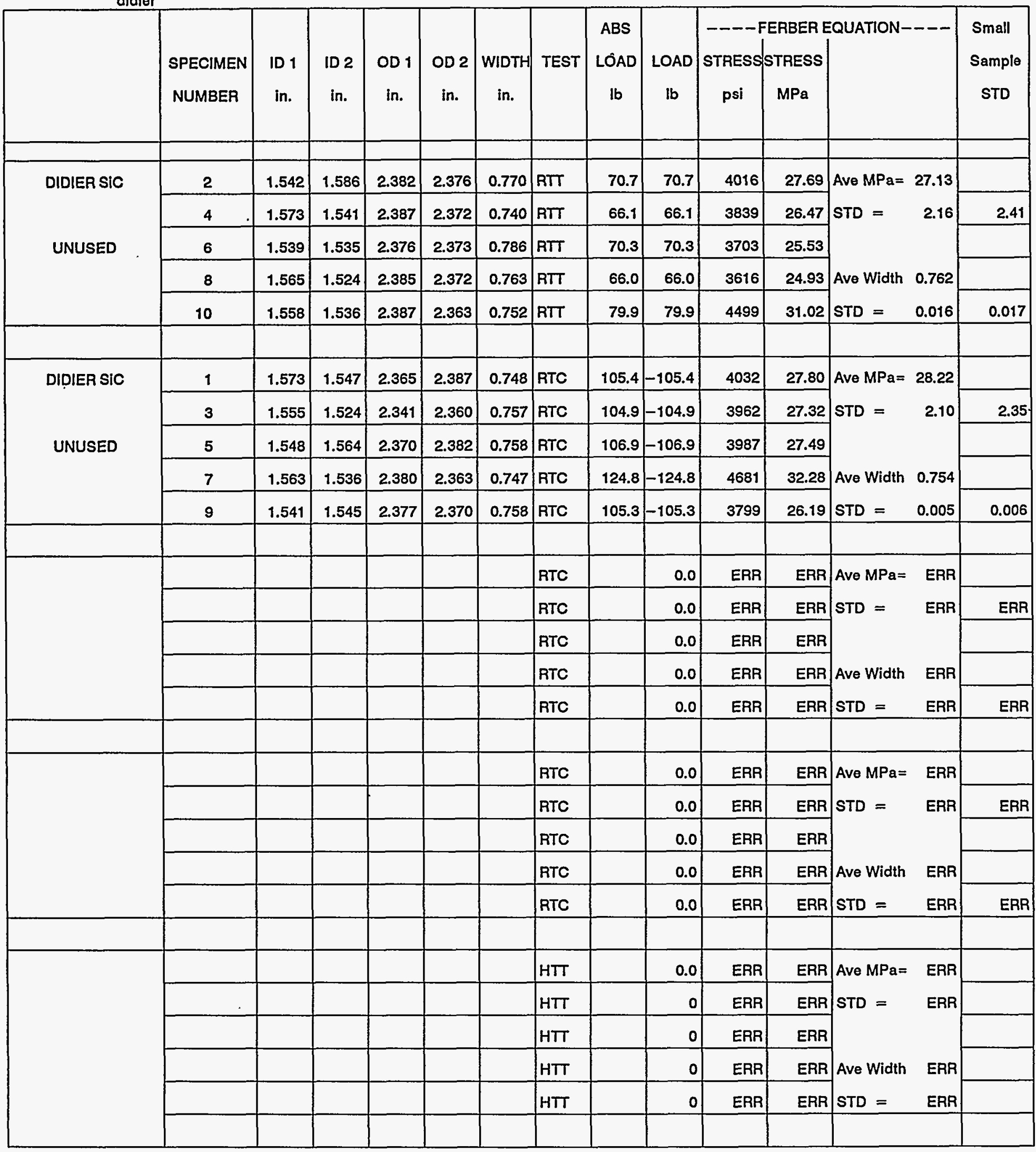


05/01/93 EXPOSURE TESTS: SCHUMACHER F40 DIA-SCHUMALITH tetsch

\begin{tabular}{|c|c|c|c|c|c|c|c|c|c|c|c|c|c|c|}
\hline & $\begin{array}{c}\text { SPECIMEN } \\
\text { NUMBER }\end{array}$ & $\begin{array}{l}\text { ID } 1 \\
\text { in. }\end{array}$ & $\begin{array}{l}\text { ID } 2 \\
\text { in. }\end{array}$ & $\begin{array}{l}\text { OD } 1 \\
\text { in. }\end{array}$ & $\begin{array}{l}O D 2 \\
\text { in. }\end{array}$ & $\begin{array}{c}\text { WIDTH } \\
\text { in. }\end{array}$ & TEST & $\begin{array}{c}\text { ABS } \\
\text { LOAD } \\
\text { lb }\end{array}$ & $\begin{array}{c}\text { LOAD } \\
\mathrm{lb}\end{array}$ & $\begin{array}{c}---F \\
\text { STRESS } \\
\text { psi }\end{array}$ & $\begin{array}{c}\text { ERBER E } \\
\text { STRESS }\end{array}$ & EQUATION- & --- & $\begin{array}{l}\text { Small } \\
\text { Sample } \\
\text { STD }\end{array}$ \\
\hline \multirow{5}{*}{$\begin{array}{c}\text { SCHUMACHER TET } \\
\text { CONTROL SAMPLE } \\
\text { Heated to } 870^{\circ} \mathrm{C} \\
\text { for } 500 \text { hours } \\
\text { TENSION @ } 870^{\circ} \mathrm{C}\end{array}$} & 2 & 1.175 & 1.187 & 2.381 & 2.376 & 0.508 & $\mathrm{HTT}$ & 25.4 & 25.4 & 1045 & 7.20 & \multirow{5}{*}{\multicolumn{2}{|c|}{ 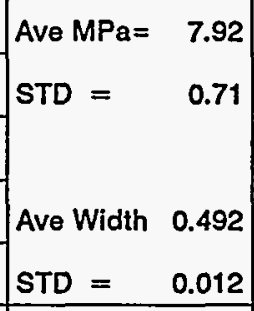 }} & \\
\hline & 4 & 1.176 & 1.172 & 2.381 & 2.385 & 0.489 & $H \pi$ & BROKE & & & & & & 1.01 \\
\hline & 6 & 1.173 & 1.184 & 2.373 & 2.386 & 0.480 & HTT & 28.9 & 28.9 & 1252 & 8.63 & & & - \\
\hline & & & & & & & $\mathrm{HTT}$ & & & & & & & \\
\hline & & & & & & & $\mathrm{HTT}$ & & & & & & & 0.014 \\
\hline \multirow{5}{*}{$\begin{array}{c}\text { SCHUMACHER TET } \\
\text { CONTROL SAMPLE } \\
\text { Heated to } 870^{\circ} \mathrm{C} \\
\text { for } 500 \text { hours } \\
\text { COMPR. @ } 870^{\circ} \mathrm{C} \\
\end{array}$} & 1 & 1.137 & 1.153 & 2.388 & 2.381 & 0.504 & HTC & 25.2 & -25.2 & 472 & 3.25 & \multirow{5}{*}{\multicolumn{2}{|c|}{ 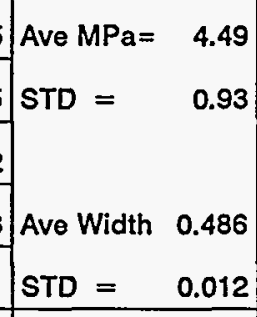 }} & \\
\hline & 3 & 1.200 & 1.173 & 2.394 & 2.368 & 0.490 & HTC & 39.7 & -39.7 & 848 & 5.85 & & & 1.07 \\
\hline & 5 & 1.177 & 1.181 & 2.380 & 2.378 & 0.473 & HTC & 30.7 & -30.7 & 670 & 4.62 & & & \\
\hline & 7 & 1.190 & 1.147 & 2.395 & 2.373 & 0.478 & HTC & 29.4 & -29.4 & 614 & 4.23 & & & \\
\hline & & & & & & & HTC & & & & & & & 0.014 \\
\hline \multirow{5}{*}{$\begin{array}{l}\text { SCHUMACHER TET } \\
100 \mathrm{hr} / 870^{\circ} \mathrm{C} / 20 \% \mathrm{H} 2 \mathrm{O} \\
\text { 95ppm NaCl/NO Pulse }\end{array}$} & A & 1.183 & 1.189 & 2.353 & 2.376 & 0.504 & $H T$ & 17.0 & 17.0 & 723 & 4.98 & \multirow{5}{*}{\multicolumn{2}{|c|}{ 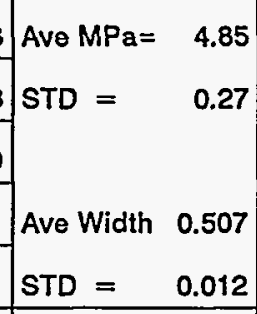 }} & \\
\hline & $3 \quad A$ & 1.194 & 1.171 & 2.383 & 2.356 & 0.522 & $\mathrm{HTT}$ & 16.0 & 16.0 & 649 & 4.48 & & & 0.33 \\
\hline & A & 1.186 & 1.169 & 2.372 & 2.332 & 0.494 & $H T T$ & 17.0 & 17.0 & 738 & 5.09 & & & \\
\hline & $\mathrm{A}$ & & & & & & $\mathrm{HTT}$ & & & & & & & \\
\hline & $\mathrm{A}$ & & & & & & $\mathrm{HTT}$ & & & & & & & 0.014 \\
\hline \multirow{5}{*}{$\begin{array}{l}\text { SCHUMACHER TET } \\
100 \mathrm{hr} / 870^{\circ} \mathrm{C} / 20 \% \mathrm{H} 20 \\
95 \mathrm{ppm} \mathrm{NaCl} / \mathrm{No} \text { Pulse }\end{array}$} & $2 \mathrm{~A}$ & 1.177 & 1.191 & 2.382 & 2.358 & 0.494 & HTC & 28.5 & -28.5 & 611 & 4.22 & \multirow{5}{*}{\multicolumn{2}{|c|}{ 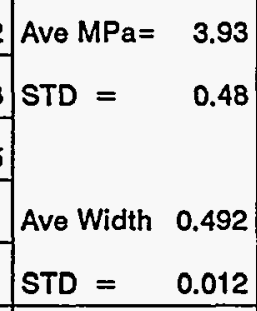 }} & \\
\hline & $4 \mathrm{~A}$ & 1.183 & 1.195 & 2.361 & 2.384 & 0.476 & HTC & 28.0 & -28.0 & 628 & 4.33 & & & 0.59 \\
\hline & $6 \quad \mathrm{~A}$ & 1.154 & 1.175 & 2.335 & 2.376 & 0.505 & HTC & 23.0 & -23.0 & 471 & 3.25 & & & \\
\hline & $\mathrm{A}$ & & & & & & HTC & & & & & & & \\
\hline & $A$ & & & & & & HTC & & & & & & & 0.015 \\
\hline \multirow{5}{*}{ COMPR @ 870 $\mathrm{C}$} & & & & & & & RTT & & 0.0 & ERR & ERR & \multirow{5}{*}{$\begin{array}{l}\text { Ave MPa = } \\
\text { STD = } \\
\text { Ave Width } \\
\text { STD = }\end{array}$} & \multirow{3}{*}{$\begin{array}{l}\text { ERR } \\
\text { ERR }\end{array}$} & \\
\hline & & & & & & & RTT & & 0 & ERR & ERR & & & \\
\hline & & & & & & & RTT & & 0 & ERR & ERR & & & \\
\hline & & & & & & & RTT & & 0 & ERR & ERR & & \multirow{2}{*}{$\begin{array}{l}\text { ERR } \\
\text { ERR } \\
\end{array}$} & \\
\hline & & & & & & & RTT & & 0 & ERR & ERR & & & \\
\hline & & & & & & & & & & & & & & \\
\hline
\end{tabular}


05/01/93 EXPOSURE TESTS: SCHUMACHER F40 DIA-SCHUMALITH tetsch

\begin{tabular}{|c|c|c|c|c|c|c|c|c|c|c|c|c|c|c|}
\hline & $\begin{array}{c}\text { SPECIMEN } \\
\text { NUMBER }\end{array}$ & $\begin{array}{l}\text { ID } 1 \\
\text { in. }\end{array}$ & $\begin{array}{l}\text { ID } 2 \\
\text { in. }\end{array}$ & $\begin{array}{l}\text { OD } 1 \\
\text { in. }\end{array}$ & $\begin{array}{c}\text { OD } 2 \\
\text { in. }\end{array}$ & $\begin{array}{c}\text { WIDTH } \\
\text { in. }\end{array}$ & TEST & $\begin{array}{c}\text { ABS } \\
\text { LOAD } \\
\mathrm{Ib}\end{array}$ & $\begin{array}{c}\text { LOAD } \\
\text { lb }\end{array}$ & $\begin{array}{c}\text { STRESS } \\
\text { psi }\end{array}$ & $\begin{array}{l}\text { FERBER E } \\
\text { STRESS } \\
\text { MPa }\end{array}$ & $\begin{array}{l}\text { EQUATION- } \\
\text { | }\end{array}$ & --- & $\begin{array}{l}\text { Small } \\
\text { Sample } \\
\text { STD }\end{array}$ \\
\hline \multirow{5}{*}{$\begin{array}{l}\text { SCHUMACHER TET } \\
100 \mathrm{hr} / 980^{\circ} \mathrm{C} / 20 \% \mathrm{H} 20 \\
65 \mathrm{ppm} \mathrm{NaCl}\end{array}$} & $1 \quad B$ & 1.178 & 1.195 & 2.365 & 2.385 & 0.520 & HTT & 3.5 & 3.5 & 142 & 0.98 & \multirow{5}{*}{\multicolumn{2}{|c|}{ 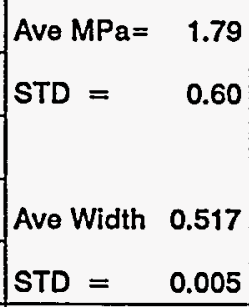 }} & \\
\hline & $3 \quad \mathrm{~B}$ & 1.178 & 1.194 & 2.356 & 2.391 & 0.521 & $H \pi$ & 7.0 & 7.0 & 285 & 1.96 & & & 0.73 \\
\hline & $5 \quad \mathrm{~B}$ & 1.178 & 1.171 & 2.350 & 2.387 & 0.509 & $H T T$ & 8.5 & 8.5 & 350 & 2.41 & & & \\
\hline & B & & & & & & $\mathrm{HTT}$ & & & & & & & \\
\hline & $\mathrm{B}$ & & & & & & $H \pi$ & & & & & & & 0.007 \\
\hline \multirow{5}{*}{$\begin{array}{l}\text { SCHUMACHER TET } \\
100 \mathrm{hr} / 980^{\circ} \mathrm{C} / 20 \% \mathrm{H} 2 \mathrm{O} \\
65 \mathrm{ppm} \mathrm{NaCl}\end{array}$} & $2 \quad B$ & 1.180 & 1.195 & 2.351 & 2.403 & 0.507 & HTC & 8.0 & -8.0 & 167 & 1.15 & \multirow{5}{*}{\multicolumn{2}{|c|}{$\begin{array}{l}\text { Ave MPa }=1.29 \\
\text { STD }= \\
\text { Ave Width } 0.499 \\
\text { STD }=0.17\end{array}$}} & \\
\hline & $4 \quad B$ & 1.172 & 1.201 & 2.361 & 2.302 & 0.509 & HTC & 10.0 & -10.0 & 223 & 1.54 & & & 0.21 \\
\hline & $6 \quad B$ & 1.189 & 1.184 & 2.372 & 2.401 & 0.480 & HTC & 8.0 & -8.0 & 173 & 1.19 & & & \\
\hline & $\mathbf{B}$ & & & & & & HTC & & & & & & & \\
\hline & $\mathrm{B}$ & & & & & & HTC & & & & & & & 0.016 \\
\hline \multirow{5}{*}{$\begin{array}{l}\text { SCHUMACHER TET } \\
475 \mathrm{hr} / 980^{\circ} \mathrm{C} / 20 \% \mathrm{H} 2 \mathrm{O} \\
65 \mathrm{ppm} \mathrm{NaCl}\left({ }^{\prime} 500 \mathrm{hr}^{\prime}\right)\end{array}$} & $\mathrm{C}$ & 1.227 & 1.211 & 2.426 & 2.388 & 0.467 & $H \pi$ & 8.6 & 8.6 & 395 & 2.72 & \multirow{5}{*}{\multicolumn{2}{|c|}{ 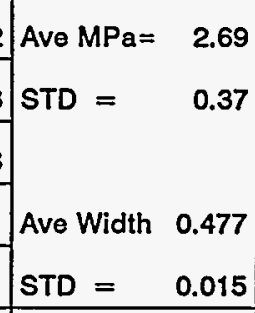 }} & \\
\hline & $\begin{array}{ll}3 & c \\
\end{array}$ & 1.204 & 1.229 & 2.404 & 2.410 & 0.498 & $\mathrm{HTT}$ & 10.6 & 10.6 & 454 & 3.13 & & & 0.45 \\
\hline & $5 \quad \mathrm{C}$ & 1.221 & 1.202 & 2.409 & 2.405 & 0.465 & $\mathrm{HTT}$ & 7.1 & 7.1 & 323 & 2.23 & & & \\
\hline & $\mathrm{C}$ & & & & & & $\mathrm{HTT}$ & & & & & & & \\
\hline & $\mathrm{c}$ & & & & & & $H \pi$ & & & & & & & 0.019 \\
\hline \multirow{5}{*}{$\begin{array}{l}\text { SCHUMACHER TET } \\
475 \mathrm{hr} / 980^{\circ} \mathrm{C} / 20 \% \mathrm{H} 2 \mathrm{O} \\
65 \mathrm{ppm} \mathrm{NaCl} \text { ("500hr") }\end{array}$} & $2 \mathrm{C}$ & 1.220 & 1.227 & 2.368 & 2.378 & 0.454 & HTC & 22.7 & -22.7 & 580 & 4.00 & \multirow{5}{*}{\multicolumn{2}{|c|}{ 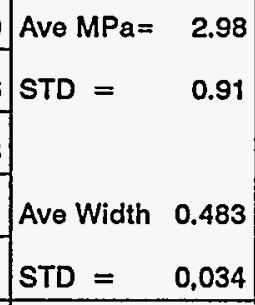 }} & \\
\hline & $4 \quad \mathrm{C}$ & 1.213 & 1.191 & 2.427 & 2.420 & 0.465 & HTC & 21.0 & -21.0 & 458 & 3.16 & & & 1.12 \\
\hline & $6 \quad \mathrm{C}$ & 1.208 & 1.211 & 2.427 & 2.395 & 0.530 & HTC & 13.0 & -13.0 & 259 & 1.78 & & & \\
\hline & c & & & & & & HTC & & & & & & & \\
\hline & $\mathrm{c}$ & & & & & & HTC & & & & & & & 0.041 \\
\hline & & & & & & & RTC & & 0 & ERR & ERR & Ave $\mathrm{MPa}=$ & ERR & \\
\hline & & & & & & & RTC & & 0 & ERR & ERR & STD $=$ & ERR & \\
\hline & & & & & & & RTC & & 0 & ERR & ERR & & & \\
\hline & & & & & & & RTC & & 0 & ERR & ERR & Ave Width & ERR & \\
\hline & & & & & & & RTC & & 0 & ERR & ERR & STD $=$ & ERR & \\
\hline & & & & & & & & & & & & & & \\
\hline
\end{tabular}


05/01/93 EXPOSURE TESTS: SCHUMACHER F40 DIA-SCHUMALITH tetsch

\begin{tabular}{|c|c|c|c|c|c|c|c|c|c|c|c|c|c|c|}
\hline & $\begin{array}{l}\text { SPECIMEN } \\
\text { NUMBER }\end{array}$ & $\begin{array}{l}\text { ID } 1 \\
\text { in. }\end{array}$ & $\begin{array}{l}\text { ID } 2 \\
\text { in. }\end{array}$ & $\begin{array}{c}\text { OD } 1 \\
\text { in. }\end{array}$ & $\begin{array}{c}O D 2 \\
\text { in. }\end{array}$ & $\begin{array}{c}\text { WIDTH } \\
\text { in. }\end{array}$ & TEST & $\begin{array}{c}\text { ABS } \\
\text { LOAAD } \\
\text { lb }\end{array}$ & $\begin{array}{c}\text { LOAD } \\
\text { lb }\end{array}$ & $\begin{array}{c}----F \\
\text { STRESS } \\
\text { psi }\end{array}$ & $\begin{array}{l}\text { ERBER } \\
\text { MPRESS } \\
\mathrm{MPa}\end{array}$ & EQUATION- & --- & $\begin{array}{c}\text { Small } \\
\text { Sample } \\
\text { STD }\end{array}$ \\
\hline SCHUMACHER TET & $\begin{array}{ll}1 & D \\
\end{array}$ & 1.206 & 1.195 & 2.388 & 2.403 & 0.431 & $\mathrm{HTT}$ & 7.8 & 7.8 & 382 & 2.63 & \multirow{2}{*}{\multicolumn{2}{|c|}{$\begin{array}{ll}\text { Ave } \mathrm{MPa}= & 2.51 \\
\mathrm{STD}= & 0.20\end{array}$}} & \\
\hline $575 \mathrm{hr} / 980^{\circ} \mathrm{C} / 20 \% \mathrm{H} 2 \mathrm{O}$ & $\begin{array}{ll}3 & \mathrm{D} \\
\end{array}$ & 1.207 & 1.206 & 2.386 & 2.418 & 0.486 & $\mathrm{HTT}$ & 8.9 & 8.9 & 387 & 2.67 & & & 0.25 \\
\hline $65 \mathrm{ppm} \mathrm{NaCl("1000hr")}$ & $\mathrm{D}$ & 1.208 & 1.180 & 2.373 & 2.353 & 0.559 & $\mathrm{HTT}$ & 8.3 & 8.3 & 323 & 2.23 & \multirow{3}{*}{\multicolumn{2}{|c|}{$\begin{array}{l}\text { Ave Width } 0.492 \\
\text { STD }=\quad 0.052\end{array}$}} & \\
\hline & $\mathrm{D}$ & & & & & & $\mathrm{HTT}$ & & & & & & & \\
\hline TENSION @ 980 $\mathrm{C}$ & $\mathrm{D}$ & & & & & & HTT & & & & & & & 0.064 \\
\hline SCHUMACHER TET & $\begin{array}{ll}2 & D \\
\end{array}$ & 1.208 & 1.185 & 2.386 & 2.413 & 0.488 & HTC & 11.4 & -11.4 & 243 & 1.68 & \multicolumn{2}{|c|}{$\begin{array}{ll}\text { Ave } \mathrm{MPa}= & 1.46 \\
\text { STD }= & 0.24\end{array} \mid$} & \\
\hline $575 \mathrm{hr} / 980^{\circ} \mathrm{C} / 20 \% \mathrm{H} 2 \mathrm{O}$ & $4 \mathrm{D}$ & 1.178 & 1.200 & 2.383 & 2.401 & 0.517 & HTC & 11.4 & -11.4 & 228 & 1.57 & & & 0.30 \\
\hline 65ppm NaCl("1000hr") & $\begin{array}{ll}6 & \mathrm{D} \\
\end{array}$ & 1.151 & 1.146 & 2.393 & 2.377 & 0.520 & HTC & 8.9 & -8.9 & 163 & 1.12 & & & \\
\hline \multirow[b]{2}{*}{ COMPR @ $980^{\circ} \mathrm{C}$} & $\mathrm{D}$ & & & & & & HTC & & & & & \multirow{2}{*}{$\begin{array}{l}\text { Ave Width } \\
\text { STD = }\end{array}$} & \multirow{2}{*}{$\begin{array}{l}0.508 \\
0.014 \\
\end{array}$} & \\
\hline & $\mathrm{D}$ & & & & & & HTC & & & & & & & 0.018 \\
\hline & & & & & & & $\mathrm{HTT}$ & & 0.0 & ERR & ERR & \multirow{3}{*}{$\begin{array}{l}\text { Ave } \mathrm{MPa}= \\
\mathrm{STD}=\end{array}$} & \multirow{2}{*}{$\begin{array}{l}\text { ERR } \\
\text { ERR }\end{array}$} & \\
\hline & $\cdot$ & & & & & & $\mathrm{HTT}$ & & 0.0 & ERR & ERR & & & ERR \\
\hline & & & & & & & $\mathrm{HTT}$ & & 0.0 & ERR & ERR & & \multirow{3}{*}{$\begin{array}{l}\text { ERR } \\
\text { ERR }\end{array}$} & \\
\hline & & & & & & & $\mathrm{HTT}$ & & 0.0 & ERR & ERR & \multirow{2}{*}{$\begin{array}{l}\text { Ave Width } \\
\text { STD }=\end{array}$} & & \\
\hline & & & & & & & $\mathrm{HTT}$ & & 0.0 & ERR & ERR & & & ERR \\
\hline & & & & & & & HTC & & 0.0 & ERR & ERR & Ave $\mathrm{MPa}=$ & ERR & \\
\hline & & & & & & & HTC & & 0.0 & ERR & ERR & STD $=$ & ERR & ERR \\
\hline & & & & & & & HTC & & 0.0 & ERR & ERR & & & \\
\hline & & & & & & & HTC & & 0.0 & ERR & ERR & Ave Width & ERR & \\
\hline & & & & & & & HTC & & 0.0 & ERR & ERR & STD $=$ & ERR & ERR \\
\hline & & & & & & & RTC & & 0 & ERR & ERR & Ave $\mathrm{MPa}=$ & ERR & \\
\hline & & & & - & & & RTC & & 0 & ERR & ERR & $S T D=$ & ERR & \\
\hline & & & & & & & RTC & & 0 & ERR & ERR & & & \\
\hline & & & & & & & RTC & & 0 & ERR & ERR & Ave Width & ERR & \\
\hline & & & & & & & RTC & & 0 & ERR & ERR & STD $=$ & ERR & \\
\hline & & & & & & & & & & & & & & \\
\hline
\end{tabular}


05/01/93 EXPOSURE TESTS: SCHUMACHER F40 DIA-SCHUMALITH tetsch

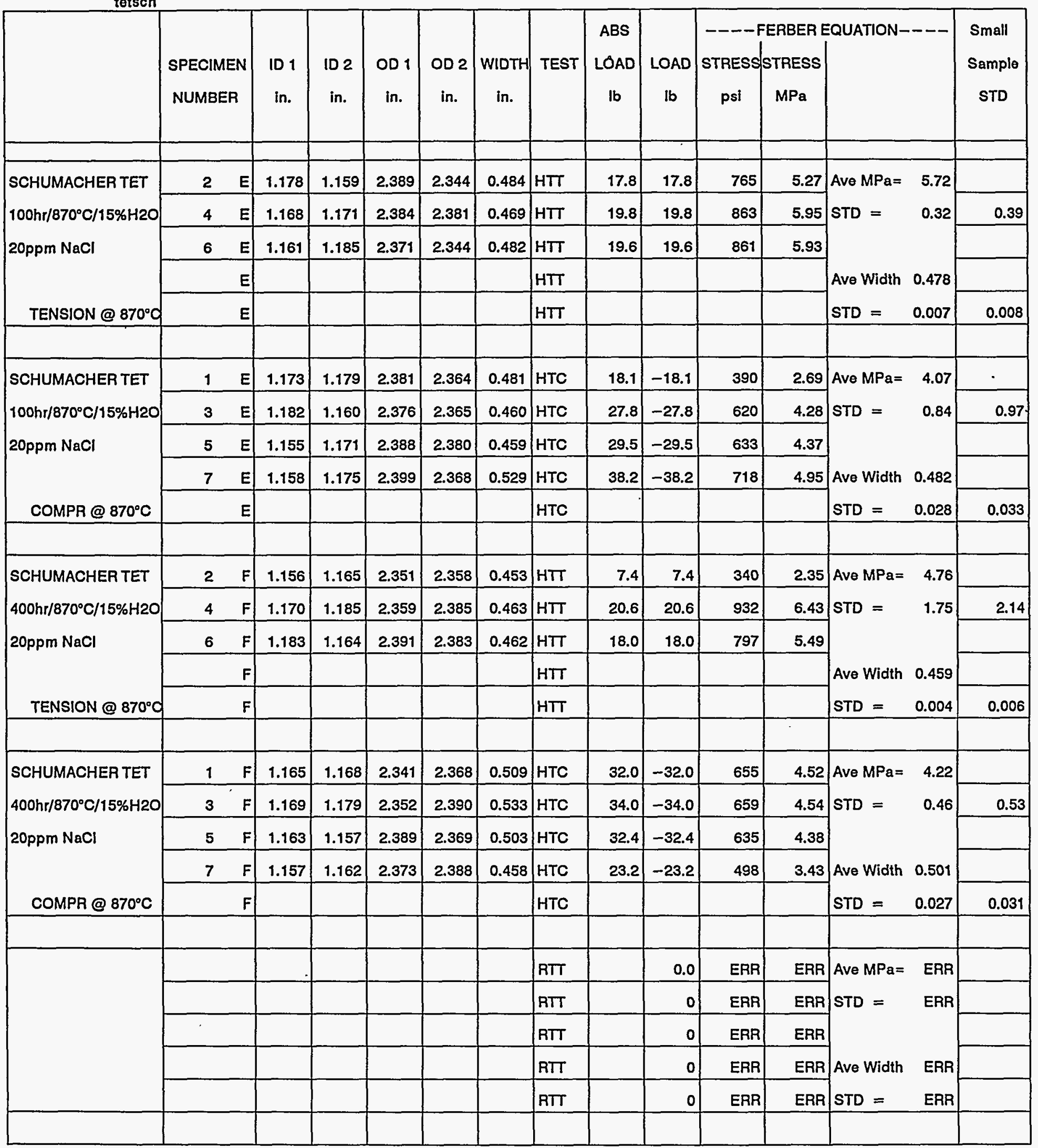


05/01/93 EXPOSURE TESTS: SCHUMACHER F40 DIA-SCHUMALITH tetsch

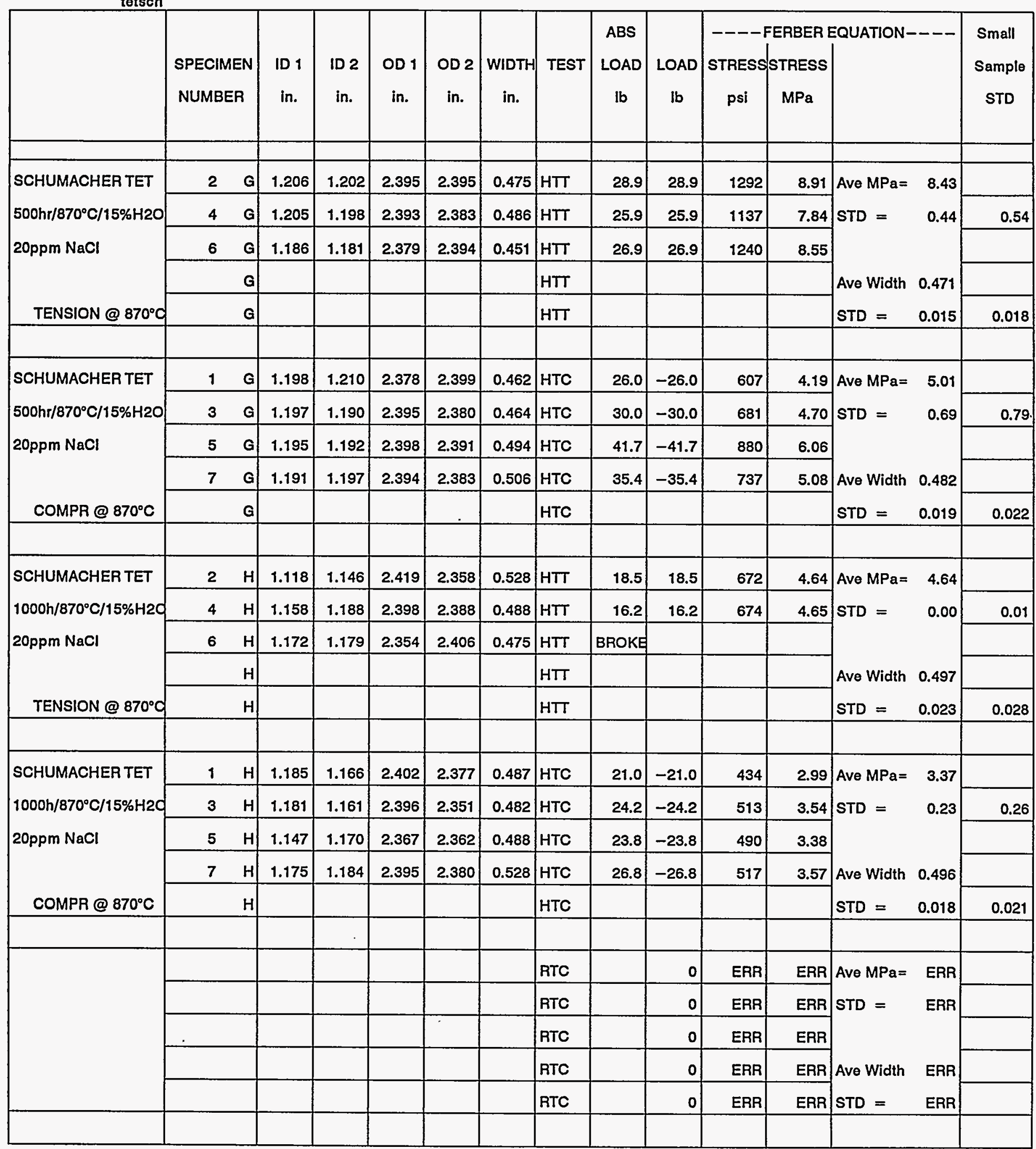


05/01/93 EXPOSURE TESTS: REFRACTRON 50/5 w/505 BINDER

tetref

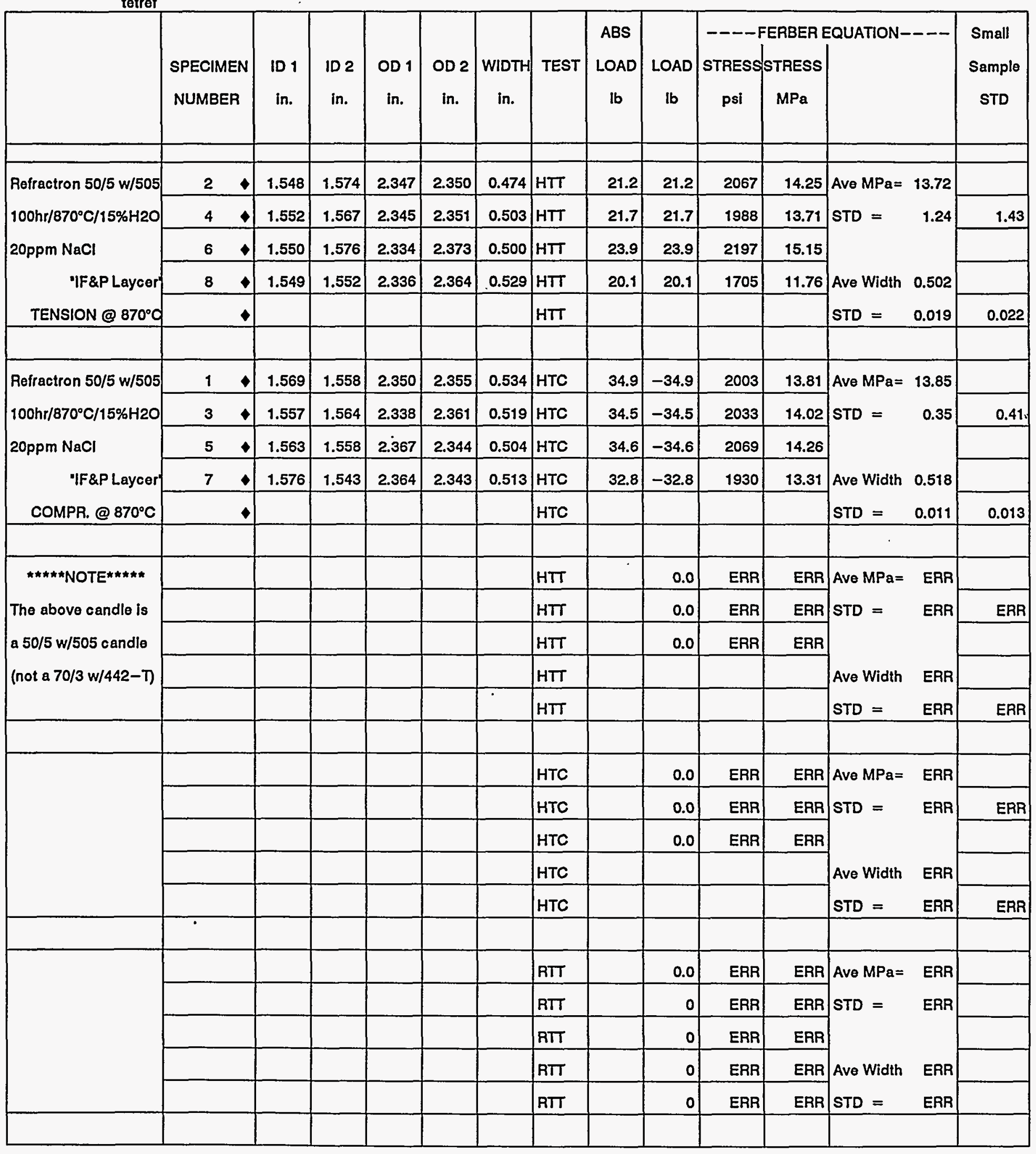


05/01/93 EXPOSURE TESTS: REFRACTRON 70/3 w/442-T BINDER

tetref

\begin{tabular}{|c|c|c|c|c|c|c|c|c|c|c|c|c|c|c|}
\hline & $\begin{array}{c}\text { SPECIMEN } \\
\text { NUMBER }\end{array}$ & $\begin{array}{l}\text { ID } 1 \\
\text { in. }\end{array}$ & $\begin{array}{l}\text { ID } 2 \\
\text { in. }\end{array}$ & $\begin{array}{c}\text { OD } 1 \\
\text { in. }\end{array}$ & $\begin{array}{c}O D 2 \\
\text { in. }\end{array}$ & $\begin{array}{c}\text { WIDTH } \\
\text { in. }\end{array}$ & TEST & $\begin{array}{c}\text { ABS } \\
\text { LOAD } \\
\text { lb }\end{array}$ & $\begin{array}{c}\text { LOAD } \\
\text { lb }\end{array}$ & $\begin{array}{c}\text { STRESS } \\
\text { psi }\end{array}$ & $\begin{array}{l}\text { ERBER E } \\
\text { MPa }\end{array}$ & EQUATION- & $-\cdots$ & $\begin{array}{c}\text { Small } \\
\text { Sample } \\
\text { STD }\end{array}$ \\
\hline \multirow{5}{*}{$\begin{array}{l}\text { Refract. } 70 / 3 \text { w/442-7 } \\
100 \mathrm{hr} / 870^{\circ} \mathrm{C} / 15 \% \mathrm{H} 2 \mathrm{O} \\
20 \mathrm{ppm} \mathrm{NaCl} / \mathrm{No} \text { Pulse } \\
\text { FRONT CANDLE } \\
\text { TENSION @ } 870^{\circ} \mathrm{O}\end{array}$} & 1 & 1.544 & 1.548 & 2.345 & 2.354 & 0.484 & $H T T$ & 25.3 & 25.3 & 2323 & 16.02 & \multirow{5}{*}{\multicolumn{2}{|c|}{ 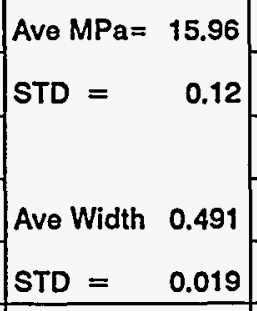 }} & \\
\hline & 1 & 1.547 & 1.545 & 2.348 & 2.352 & 0.473 & HTT & 24.4 & 24.4 & 2290 & 15.79 & & & 0.15 \\
\hline & 1 & 1.539 & 1.553 & 2.355 & 2.362 & 0.517 & HTT & 27.6 & 27.6 & 2330 & 16.06 & & & \\
\hline & 1 & & & & & & HTT & & & & & & & \\
\hline & 1 & & & & & & $\mathrm{HTT}$ & & & & & & & 0.023 \\
\hline \multirow{5}{*}{$\begin{array}{l}\text { Refract. } 70 / 3 \text { w/442-T } \\
100 \mathrm{hr} / 870^{\circ} \mathrm{C} / 15 \% \mathrm{H} 2 \mathrm{O} \\
20 \mathrm{ppm} \mathrm{NaCl} / \mathrm{No} \text { Pulse } \\
\text { FRONT CANDLE } \\
\text { COMPR. @ } 870^{\circ} \mathrm{C}\end{array}$} & 1 & 1.558 & 1.544 & 2.358 & 2.370 & 0.504 & HTC & 37.3 & -37.3 & 2121 & 14.63 & \multirow{5}{*}{\multicolumn{2}{|c|}{ 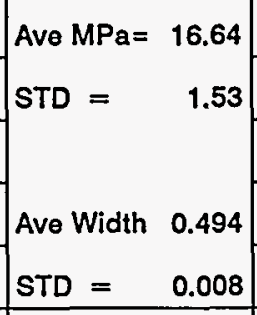 }} & \\
\hline & 1 & 1.543 & 1.540 & 2.345 & 2.357 & 0.491 & HTC & 46.0 & -46.0 & 2692 & .18 .56 & & & 1.77. \\
\hline & 1 & 1.557 & 1.544 & 2.358 & 2.348 & 0.482 & HTC & 41.8 & -41.8 & 2549 & 17.58 & & & \\
\hline & 1 & 1.536 & 1.538 & 2.357 & 2.359 & 0.499 & HTC & 41.0 & -41.0 & 2290 & 15.79 & & & \\
\hline & 1 & & & & & & HTC & & & & & & & 0.010 \\
\hline \multirow{5}{*}{$\begin{array}{l}\text { Refract. } 70 / 3 \text { w/442-7 } \\
100 \mathrm{hr} / 870^{\circ} \mathrm{C} / 15 \% \mathrm{H} 20 \\
20 \mathrm{ppm} \mathrm{NaCl} / \mathrm{No} \text { Pulse } \\
\text { REAR CANDLE } \\
\text { TENSION @ } 870^{\circ} \mathrm{O}\end{array}$} & 2 & 1.556 & 1.567 & 2.358 & 2.365 & 0.486 & $H \pi$ & 33.6 & 33.6 & 3114 & 21.47 & \multicolumn{2}{|c|}{$\begin{array}{l}\text { Ave MPa = } \\
\text { STD }= \\
\text { Ave Width } \\
\text { STD }=0.508\end{array}$} & \\
\hline & I & 1.549 & 1.555 & 2.356 & 2.370 & 0.486 & $H \pi$ & 24.5 & 24.5 & 2212 & 15.25 & & & 4.35 \\
\hline & 6 & 1.552 & 1.555 & 2.362 & 2.351 & 0.552 & $H T T$ & 23.5 & 23.5 & 1900 & 13.10 & & & \\
\hline & 1 & & & & & & $H T T$ & & & & & & & \\
\hline & 1 & & & & & & $H T T$ & & & & & & & 0.038 \\
\hline \multirow{10}{*}{$\begin{array}{l}\text { Refract. } 70 / 3 \text { w/442- } \\
100 \mathrm{hr} / 870^{\circ} \mathrm{C} / 15 \% \mathrm{H} 2 \mathrm{O} \\
20 p p m \mathrm{NaCl} / \mathrm{No} \text { Pulse } \\
\text { REAR CANDLE } \\
\text { COMPR. @ } 870^{\circ} \mathrm{C}\end{array}$} & 1 & 1.554 & 1.570 & 2.367 & 2.371 & 0.494 & HTC & 40.1 & -40.1 & 2377 & 16.39 & \multirow{5}{*}{\multicolumn{2}{|c|}{ 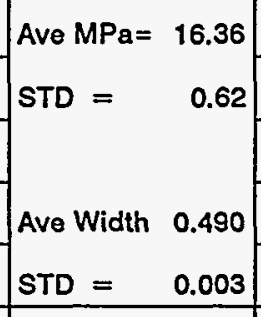 }} & \\
\hline & 1 & 1.550 & 1.511 & 2.347 & 2.364 & 0.490 & HTC & 44.9 & -44.9 & 2519 & 17.37 & & & 0.72 \\
\hline & 1 & 1.551 & 1.558 & 2.356 & 2.385 & 0.485 & HTC & 39.1 & -39.1 & 2299 & 15.85 & & & \\
\hline & $\begin{array}{ll}7 & 1 \\
\end{array}$ & 1.548 & 1.543 & 2.370 & 2.351 & 0.489 & HTC & 39.5 & -39.5 & 2296 & 15.83 & & & \\
\hline & 1 & & & & & & HTC & & & & & & & 0.004 \\
\hline & & & & & & & RTC & & 0 & ERR & ERR & Ave $\mathrm{MPa}=$ & ERR & . \\
\hline & & & & & & & RTC & & 0 & ERR & ERR & STD $=$ & ERR & \\
\hline & & & & & & & RTC & & 0 & ERR & ERR & & & \\
\hline & & & & & & & RTC & & 0 & ERR & ERR & Ave Width & ERR & \\
\hline & & & & & & & RTC & & 0 & ERR & ERR & STD = & ERR & \\
\hline & & & & & & & & & & & & & & \\
\hline
\end{tabular}


05/01/93 EXPOSURE TESTS: REFRACTRON 70/3 w/442-T BINDER

\begin{tabular}{|c|c|c|c|c|c|c|c|c|c|c|c|c|c|c|}
\hline & $\begin{array}{c}\text { SPECIMEN } \\
\text { NUMBER }\end{array}$ & $\begin{array}{l}\text { ID } 1 \\
\text { in. }\end{array}$ & $\begin{array}{l}\text { ID } 2 \\
\text { in. }\end{array}$ & $\begin{array}{l}\text { OD } 1 \\
\text { in. }\end{array}$ & $\begin{array}{l}\text { OD } 2 \\
\text { in. }\end{array}$ & $\begin{array}{c}\text { WIDTH } \\
\text { in. }\end{array}$ & TEST & $\begin{array}{c}A B S \\
\text { LOAD } \\
\text { Ib }\end{array}$ & $\begin{array}{c}\text { LOAD } \\
\text { lb }\end{array}$ & $\begin{array}{c}---F \\
\text { STRESS } \\
\text { psi }\end{array}$ & $\begin{array}{l}\text { ERBER E } \\
\text { STRESS } \\
\text { MPa }\end{array}$ & EQUATION- & --- & $\begin{array}{l}\text { Small } \\
\text { Sample } \\
\text { STD }\end{array}$ \\
\hline \multirow{5}{*}{$\begin{array}{l}\text { Refract. } 70 / 3 \mathrm{w} / 442-\mathrm{T} \\
100 \mathrm{hr} / 870^{\circ} \mathrm{C} / 15 \% \mathrm{H} 2 \mathrm{O} \\
20 \mathrm{ppm} \mathrm{NaCl}\end{array}$} & $\begin{array}{ll}2 & \mathrm{~J} \\
\end{array}$ & 1.544 & 1.508 & 2.335 & 2.345 & 0.466 & $H T T$ & 22.9 & 22.9 & 2121 & 14.62 & \multirow{5}{*}{\multicolumn{2}{|c|}{ 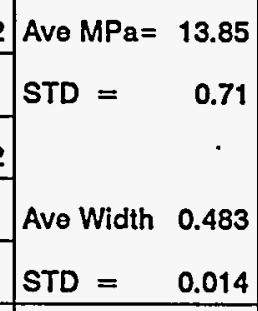 }} & \\
\hline & $\begin{array}{ll}4 & \mathrm{~J}\end{array}$ & 1.541 & 1.524 & 2.347 & 2.339 & 0.484 & $H T T$ & 20.8 & 20.8 & 1873 & 12.91 & & & 0.87 \\
\hline & $\begin{array}{ll}6 & \mathrm{~J} \\
\end{array}$ & 1.524 & 1.551 & 2.339 & 2.332 & 0.500 & $\mathrm{HTT}$ & 22.7 & 22.7 & 2033 & 14.02 & & & \\
\hline & J) & & & & & & $\mathrm{HTT}$ & & & & & & & \\
\hline & $\mathrm{J}$ & & & & & & $\mathrm{HT}$ & & & & & & & 0.017 \\
\hline \multirow{5}{*}{$\begin{array}{l}\text { Refract. } 70 / 3 \text { w/442-T } \\
100 \mathrm{hr} / 870^{\circ} \mathrm{C} / 15 \% \mathrm{H} 2 \mathrm{O} \\
20 \mathrm{ppm} \mathrm{NaCl}\end{array}$} & $\mathrm{J}$ & 1.521 & 1.540 & 2.349 & 2.324 & 0.499 & HTC & 45.8 & -45.8 & 2642 & 18.21 & \multirow{5}{*}{\multicolumn{2}{|c|}{ 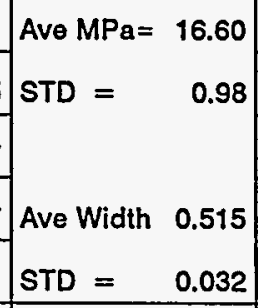 }} & \\
\hline & $\mathrm{J}$ & 1.535 & 1.526 & 2.325 & 2.345 & 0.491 & HTC & 40.3 & -40.3 & 2371 & 16.35 & & & 1.13 \\
\hline & $J$ & 1.535 & 1.520 & 2.343 & 2.321 & 0.501 & HTC & 41.0 & -41.0 & 2359 & 16.27 & & & \\
\hline & $\mathrm{J}$ & 1.528 & 1.535 & 2.333 & 2.329 & 0.570 & HTC & 44.0 & -44.0 & 2259 & 15.57 & & & \\
\hline & J) & & & & & & HTC & & & & & & & 0.037 \\
\hline \multirow{5}{*}{$\begin{array}{l}\text { Refract. } 70 / 3 \mathrm{w} / 442-\mathrm{T} \\
400 \mathrm{hr} / 870^{\circ} \mathrm{C} / 15 \% \mathrm{H} 2 \mathrm{O} \\
20 \mathrm{ppm} \mathrm{NaCl}\end{array}$} & $2 \quad K$ & 1.518 & 1.522 & 2.365 & 2.362 & 0.467 & HTT & 21.8 & 21.8 & 1897 & 13.08 & \multirow{5}{*}{\multicolumn{2}{|c|}{ 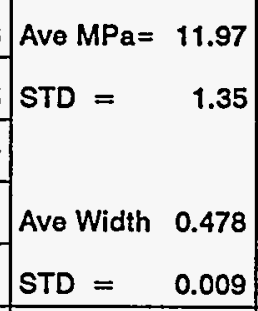 }} & \\
\hline & $4 \mathrm{~K}$ & 1.515 & 1.515 & 2.351 & 2.386 & 0.480 & HTT & 22.3 & 22.3 & 1849 & 12.75 & & & 1.65 \\
\hline & $\begin{array}{ll}6 & K \\
\end{array}$ & 1.523 & 1.515 & 2.363 & 2.365 & 0.488 & HTT & 17.6 & 17.6 & 1461 & 10.07 & & & \\
\hline & $\mathrm{K}$ & & & & & & HTT & & & & & & & \\
\hline & $\mathrm{K}$ & . & & & & & HTT & & & & & & & 0.011 \\
\hline \multirow{10}{*}{$\begin{array}{l}\text { Refract. } 70 / 3 \mathrm{w} / 442-7 \\
400 \mathrm{hr} / 870^{\circ} \mathrm{C} / 15 \% \mathrm{H} 2 \mathrm{O} \\
20 \mathrm{ppm} \mathrm{NaCl}\end{array}$} & $\mathrm{K}$ & 1.514 & 1.501 & 2.362 & 2.355 & 0.490 & HTC & 31.1 & -31.1 & 1617 & 11.15 & \multirow{5}{*}{\multicolumn{2}{|c|}{ 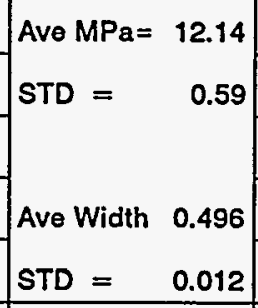 }} & \\
\hline & $\begin{array}{ll}3 & K \\
\end{array}$ & 1.514 & 1.526 & 2.356 & 2.386 & 0.488 & HTC & 33.8 & -33.8 & 1779 & 12.27 & & & 0.68 \\
\hline & $\begin{array}{ll}5 & K \\
\end{array}$ & 1.527 & 1.518 & 2.375 & 2.374 & 0.516 & HTC & 36.9 & -36.9 & 1836 & 12.66 & & & \\
\hline & $\begin{array}{ll}7 & \mathrm{~K} \\
\end{array}$ & 1.501 & 1.520 & 2.358 & 2.373 & 0.488 & HTC & 34.9 & -34.9 & 1809 & 12.47 & & & \\
\hline & $K$ & & & & & & HTC & & & & & & & 0.014 \\
\hline & & & & & & & RTC & & 0 & ERR & ERR & Ave $\mathrm{MPa}=$ & ERR & \\
\hline & & & & & & & RTC & & 0 & ERR & ERR & STD $=$ & ERR & \\
\hline & & & & & & & RTC & & 0 & ERR & ERR & & & \\
\hline & & & & & & & RTC & & 0 & ERR & ERR & Ave Width & ERR & \\
\hline & & & & & & & RTC & & 0 & ERR & ERR & STD $=$ & ERR & \\
\hline & & & & & & & & & & & & $+=$ & & \\
\hline
\end{tabular}


05/01/93 EXPOSURE TESTS: REFRACTRON 70/3 w/442-T BINDER tetref

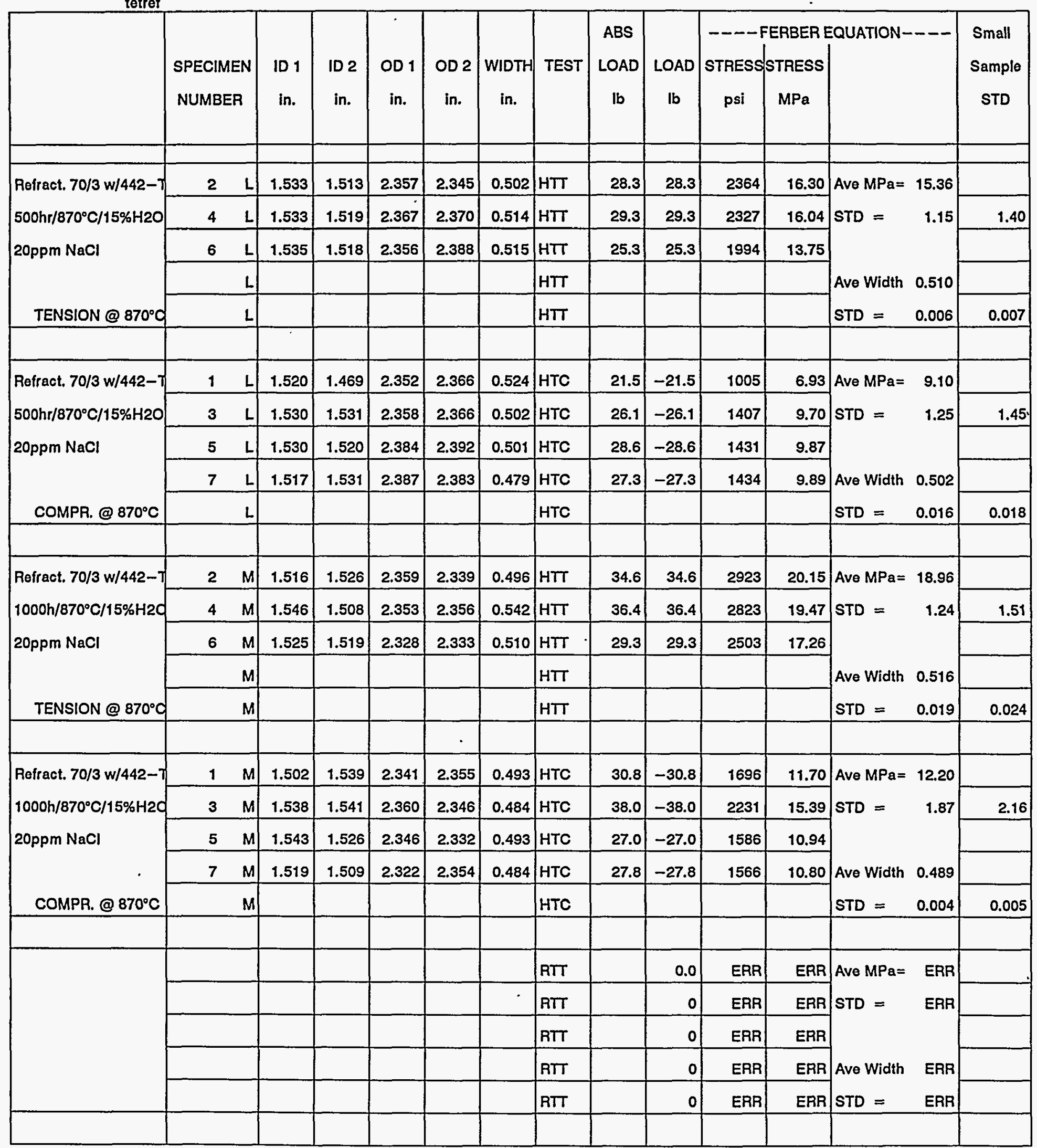


05/01/93 EXPOSURE TESTS: REFRACTRON 70/3 w/442-T BINDER tetref

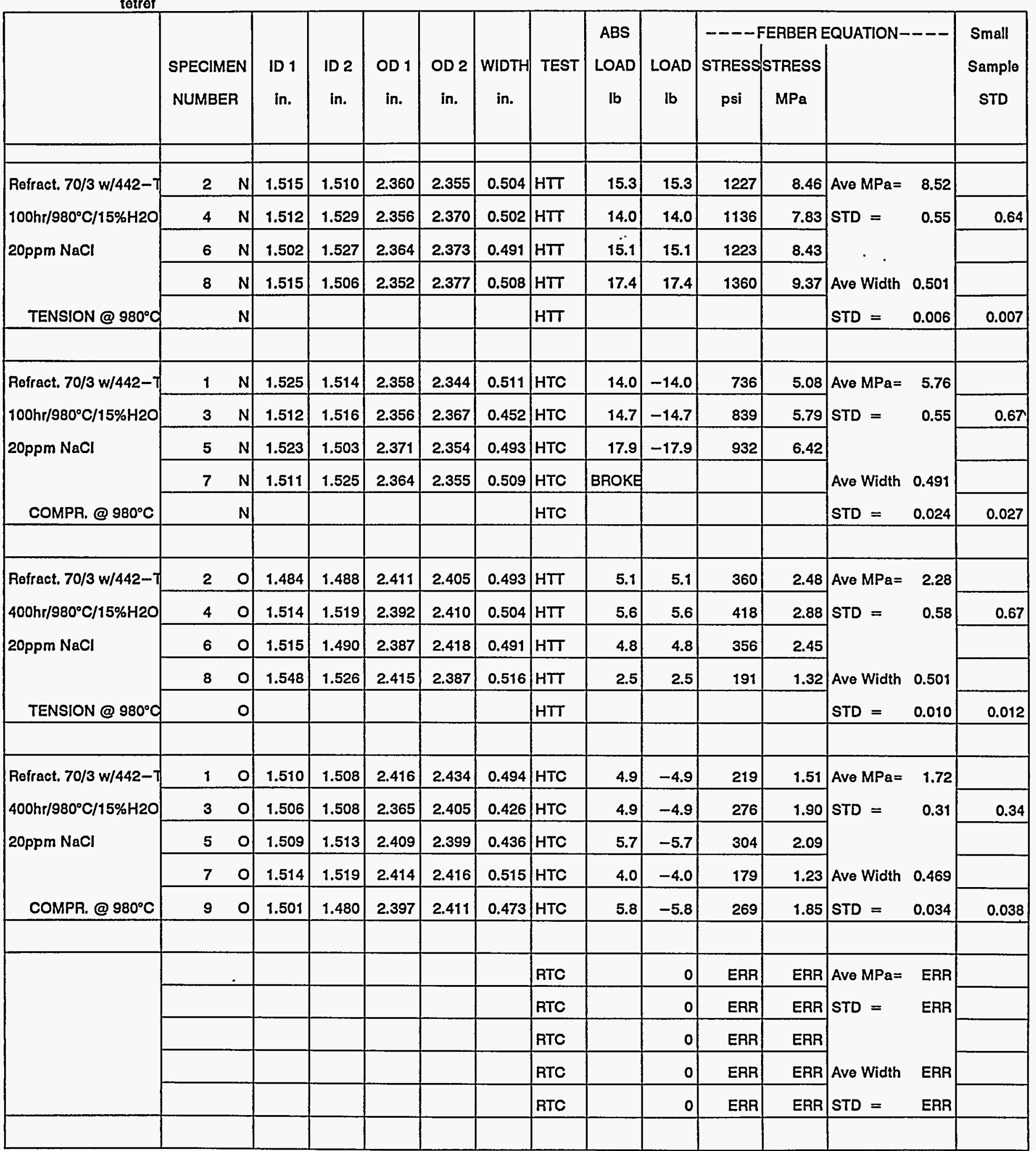


05/01/93 EXPOSURE TESTS: REFRACTRON 70/3 w/442-T BINDER tetref

\begin{tabular}{|c|c|c|c|c|c|c|c|c|c|c|c|c|c|c|}
\hline & $\begin{array}{l}\text { SPECIMEN } \\
\text { NUMBER }\end{array}$ & $\begin{array}{l}\text { ID } 1 \\
\text { in. }\end{array}$ & $\begin{array}{l}\text { ID } 2 \\
\text { in. }\end{array}$ & $\begin{array}{l}\text { OD } 1 \\
\text { in. }\end{array}$ & $\begin{array}{c}\text { OD } 2 \\
\text { in. }\end{array}$ & $\begin{array}{c}\text { WIDTH } \\
\text { in. }\end{array}$ & TEST & $\begin{array}{c}\text { ABS } \\
\text { LOAD } \\
\text { lb }\end{array}$ & $\begin{array}{c}\text { LOAD } \\
\text { lb }\end{array}$ & \multicolumn{4}{|c|}{\begin{tabular}{l|c|}
--- FERBER EQUATION $-\cdots-$ \\
STRESS STRESS \\
psi \\
$\mathrm{MPa}$
\end{tabular}} & $\begin{array}{l}\text { Small } \\
\text { Sample } \\
\text { STD }\end{array}$ \\
\hline Refract. $70 / 3$ w/442-T & $\mathbf{P}$ & 1.517 & 1.481 & 2.368 & 2.389 & 0.477 & HTT & 3.3 & 3.3 & 261 & 1.80 & \multirow{5}{*}{\multicolumn{2}{|c|}{$\begin{array}{l}\text { Ave MPa }=1.68 \\
\text { STD }=\quad 0.15\end{array}$}} & \\
\hline $500 \mathrm{hr} / 980^{\circ} \mathrm{C} / 15 \% \mathrm{H} 2 \mathrm{O}$ & $4 P$ & 1.504 & 1.498 & 2.386 & 2.372 & 0.482 & HTT & 2.7 & 2.7 & 212 & 1.46 & & & 0.17 \\
\hline \multirow{3}{*}{$\begin{array}{l}\text { 20ppm NaCl } \\
\text { TENSION @ } 980^{\circ} \mathrm{C}\end{array}$} & $\mathbf{P}$ & 1.506 & 1.506 & 2.381 & 2.371 & 0.491 & HTT & 3.4 & 3.4 & 266 & 1.84 & & & \\
\hline & $8 \quad P$ & 1.494 & 1.422 & 2.375 & 2.387 & 0.492 & $\mathrm{HTT}$ & 3.4 & 3.4 & 237 & 1.64 & & & \\
\hline & $\mathbf{P}$ & & & & & & HTT & & & & & & & 0.007 \\
\hline \multirow{4}{*}{$\begin{array}{l}\text { Refract. } 70 / 3 \text { w/442-7 } \\
500 \mathrm{hr} / 980^{\circ} \mathrm{C} / 15 \% \mathrm{H} 2 \mathrm{O} \\
20 \mathrm{ppm} \mathrm{NaCl}\end{array}$} & $1 \quad P$ & 1.497 & 1.507 & 2.365 & 2.378 & 0.482 & HTC & 3.7 & -3.7 & 187 & 1.29 & \multicolumn{2}{|c|}{$\begin{array}{ll}\text { Ave MPa }= & 1.17 \\
\text { STD }= & 0.18 \\
\text { Ave Width } & 0.506 \\
\text { STD }= & 0.059\end{array}$} & \\
\hline & $3 \quad P$ & 1.501 & 1.495 & 2.372 & 2.387 & 0.482 & HTC & 3.0 & -3.0 & 147 & 1.01 & & & 0.20 \\
\hline & $5 \quad \mathrm{P}$ & 1.505 & 1.487 & 2.371 & 2.389 & 0.489 & HTC & 3.8 & -3.8 & 182 & 1.26 & & & \\
\hline & $\begin{array}{ll}7 & P \\
\end{array}$ & 1.506 & 1.512 & 2.366 & 2.386 & 0.456 & HTC & 3.7 & -3.7 & 200 & 1.38 & & & \\
\hline COMPR. @ $980^{\circ} \mathrm{C}$ & $\begin{array}{ll}9 & P \\
\end{array}$ & 1.441 & 1.429 & 2.347 & 2.379 & 0.621 & HTC & 4.0 & -4.0 & 132 & 0.91 & & & 0.066 \\
\hline \multirow{5}{*}{$\begin{array}{l}\text { Refract. } 70 / 3 \mathrm{w} / 442-7 \\
1000 \mathrm{~h} / 980^{\circ} \mathrm{C} / 15 \% \mathrm{H} 2 \mathrm{~d} \\
20 \mathrm{ppm} \mathrm{NaCl}\end{array}$} & 20 & 1.523 & 1.476 & 2.541 & 2.477 & 0.459 & $\mathrm{HTT}$ & 6.5 & 6.5 & 430 & 2.96 & \multirow{5}{*}{\multicolumn{2}{|c|}{ 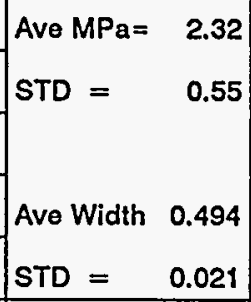 }} & \\
\hline & $\begin{array}{r}-4 \\
\end{array}$ & 1.540 & 1.513 & 2.516 & 2.469 & 0.506 & $\mathrm{HTT}$ & 6.2 & 6.2 & 402 & 2.77 & & & 0.64 \\
\hline & $6 \quad Q$ & 1.510 & 1.543 & 2.461 & 2.463 & 0.496 & $\mathrm{HTT}$ & 3.6 & 3.6 & 251 & 1.73 & & & \\
\hline & $8 \quad \mathrm{Q}$ & 1.556 & 1.503 & 2.480 & 2.441 & 0.513 & $\mathrm{HTT}$ & 3.9 & 3.9 & 265 & 1.83 & & & \\
\hline & $\mathbf{Q}$ & & & & & & HTT & & & & & & & 0.024 \\
\hline \multirow{10}{*}{$\begin{array}{l}\text { Refract. } 70 / 3 \text { w/442-7 } \\
1000 \mathrm{~h} / 980^{\circ} \mathrm{C} / 15 \% \mathrm{H} 2 \mathrm{O} \\
20 \mathrm{ppm} \mathrm{NaCl} \\
\text { COMPR. @ } 980^{\circ} \mathrm{C}\end{array}$} & $1 \quad Q$ & 1.515 & 1.471 & 2.426 & 2.437 & 0.517 & HTC & 6.4 & -6.4 & 258 & 1.78 & \multirow{5}{*}{\multicolumn{2}{|c|}{ 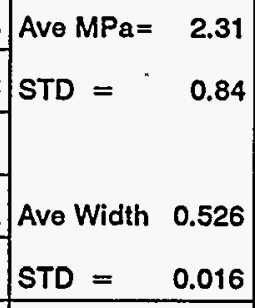 }} & \\
\hline & $3 \quad Q$ & 1.540 & 1.549 & 2.514 & 2.426 & 0.520 & HTC & 7.0 & -7.0 & 298 & 2.05 & & & 0.93 \\
\hline & $\begin{array}{ll}5 & Q \\
\end{array}$ & 1.516 & 1.531 & 2.470 & 2.480 & 0.554 & HTC & 6.4 & -6.4 & 239 & 1.65 & & & \\
\hline & $\begin{array}{ll}7 & Q\end{array}$ & 1.495 & 1.517 & 2.434 & 2.459 & 0.531 & HTC & 7.8 & -7.8 & 307 & 2.12 & & & \\
\hline & $\begin{array}{ll}9 & 0 \\
\end{array}$ & 1.512 & 1.548 & 2.405 & 2.418 & 0.506 & HTC & 12.0 & -12.0 & 572 & 3.94 & & & 0.018 \\
\hline & & & & & & & RTC & & 0 & ERR & ERR & Ave $\mathrm{MPa}=$ & ERR & \\
\hline & & & & & & & RTC & & 0 & ERR & ERR & STD $=$ & ERR & \\
\hline & & & & & & & RTC & & 0 & ERR & ERR & & & \\
\hline & & & & & & & RTC & & 0 & ERR & ERR & Ave Width & ERR & \\
\hline & & & & & & & RTC & & 0 & ERR & ERR & STD $=$ & ERR & \\
\hline & & & & & & & & & & & & & & \\
\hline
\end{tabular}


$-254-$

This Page Intentionally Left Blank 
$-255-$

APPENDIX E

X-RAY DIFFRACTION DATA

E-1 
$-256-$

This Page Intentionally Left Blank 


\begin{tabular}{|c|c|c|c|c|c|c|c|c|c|c|c|c|}
\hline 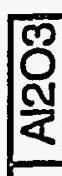 & 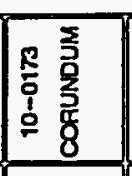 & & 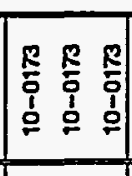 & 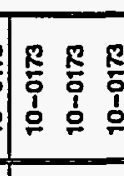 & 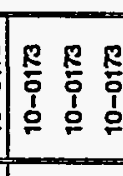 & 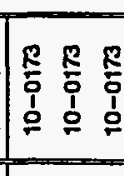 & 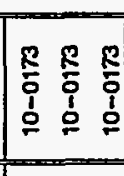 & 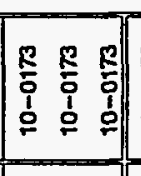 & 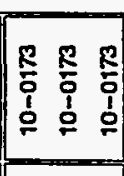 & $\mid \begin{array}{lll}0 & R \\
0 & 0 & 0 \\
0 & 0 \\
0 & 0 \\
0 & 0\end{array}$ & 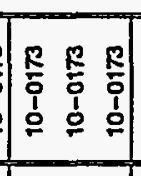 & $\begin{array}{ll}0 \\
0\end{array}$ \\
\hline 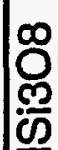 & 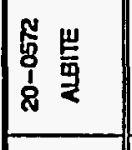 & & & & & & & & & 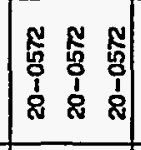 & 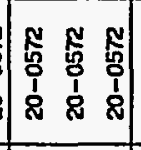 & $\begin{array}{ll}0 \\
0 \\
0\end{array}$ \\
\hline$\frac{\bar{s}}{2}$ & 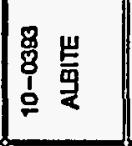 & & & & & & & & & $\mid \begin{array}{lll}8 & 8 & 8 \\
0 & 8 & 8 \\
1 & 1 \\
1 & 1 & 1 \\
0 & 0 & 0\end{array}$ & 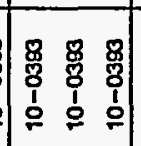 & 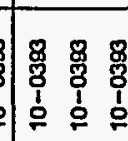 \\
\hline & 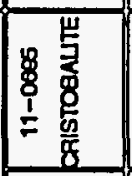 & & 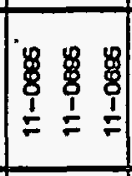 & 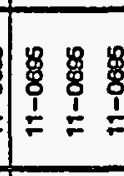 & 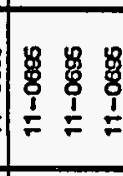 & 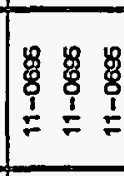 & & & & & & \\
\hline تَ & 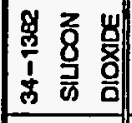 & & & & & & & 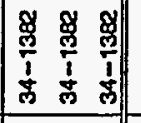 & & & & \\
\hline$\frac{\bar{v}}{\bar{\omega}}$ & 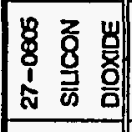 & & & & $\begin{array}{lll}8 & 0 & 8 \\
8 & 8 & 8 \\
1 & 1 & 1 \\
& 1 & 1\end{array}$ & 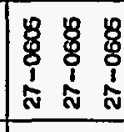 & 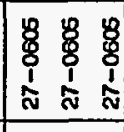 & 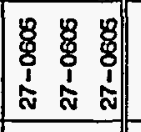 & & 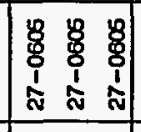 & $\left|\begin{array}{lll}8 & 8 \\
8 & 8 & 8 \\
1 & 1 & 5 \\
N & 5\end{array}\right|$ & $\begin{array}{ll}8 & 8 \\
8 & 8 \\
1 & 8 \\
1 & 1\end{array}$ \\
\hline & 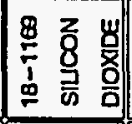 & & & & & 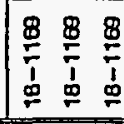 & & 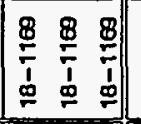 & & & & 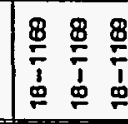 \\
\hline & 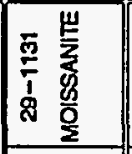 & 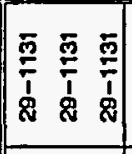 & & & & & 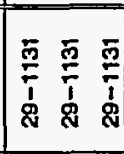 & 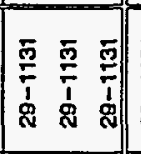 & 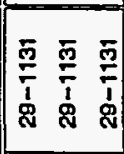 & & & 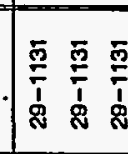 \\
\hline & 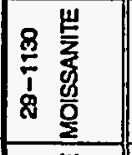 & & & & & & & & & 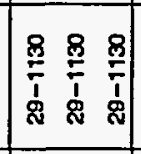 & $\mid \begin{array}{lll}8 & 8 & 8 \\
\frac{8}{1} & \frac{8}{7} & \frac{1}{1} \\
8 & 1 & 8 \\
8 & 8\end{array}$ & \\
\hline 0 & 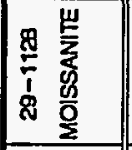 & 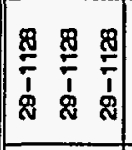 & 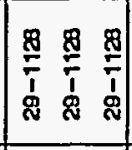 & 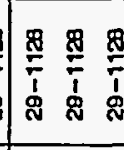 & 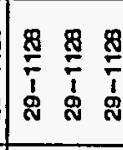 & 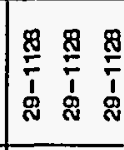 & & 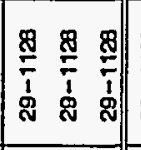 & 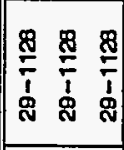 & 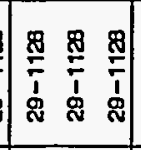 & & \\
\hline $\begin{array}{l}\dot{\omega} \\
\dot{u} \\
\underline{0}\end{array}$ & 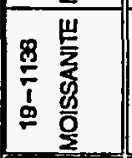 & & 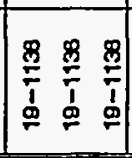 & & & & & & & & 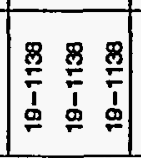 & \\
\hline$\frac{m}{\frac{m}{8}}$ & 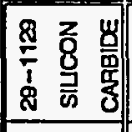 & 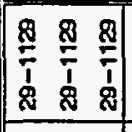 & & 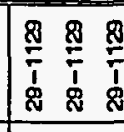 & 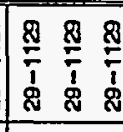 & 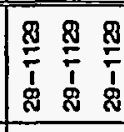 & & 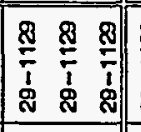 & 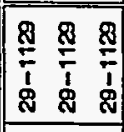 & 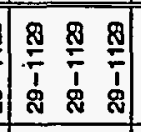 & 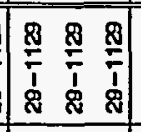 & \\
\hline \begin{tabular}{|l|} 
\\
0 \\
0 \\
\end{tabular} & 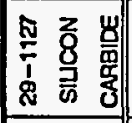 & & & & & & 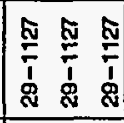 & & 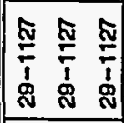 & $\begin{array}{lll}\pi & \pi & 0 \\
2 & 1 & 0 \\
8 & 8 & 8\end{array}$ & & 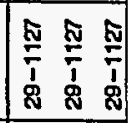 \\
\hline $\bar{\omega}$ & 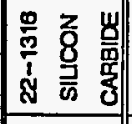 & 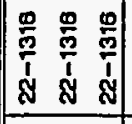 & & & & & & & 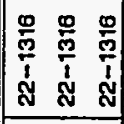 & 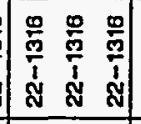 & & \\
\hline & 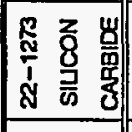 & 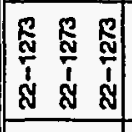 & & & & & 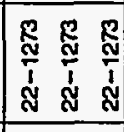 & & & 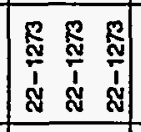 & & \\
\hline & 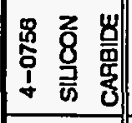 & & & & 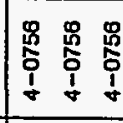 & & & & & & & \\
\hline & 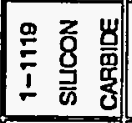 & & 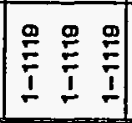 & & & & & & & & & \\
\hline 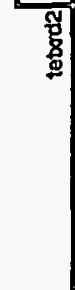 & 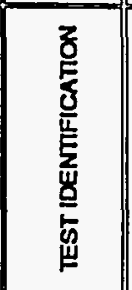 & 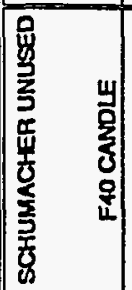 & 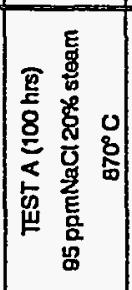 & 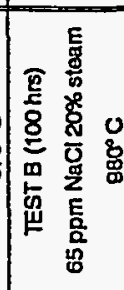 & 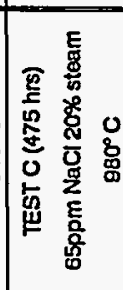 & 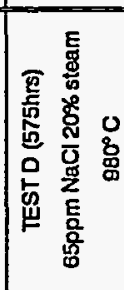 & 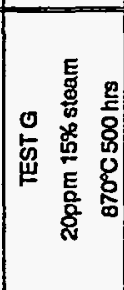 & 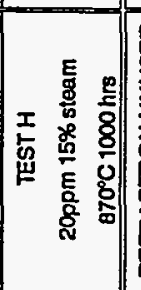 & 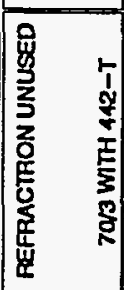 & 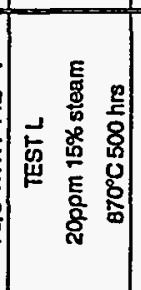 & 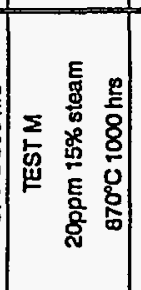 & 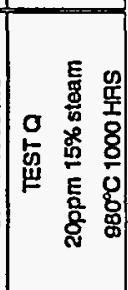 \\
\hline
\end{tabular}


$-258-$

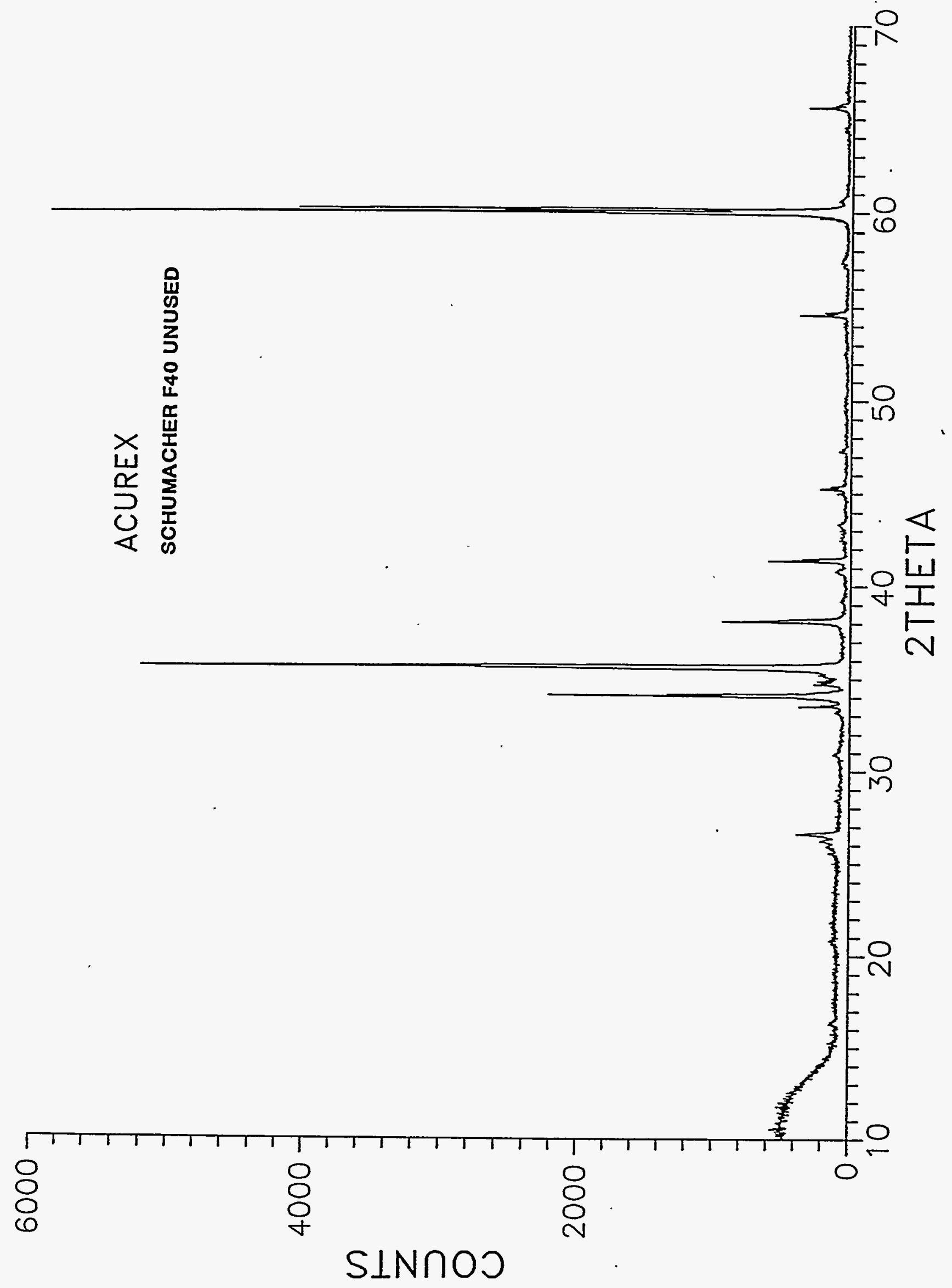




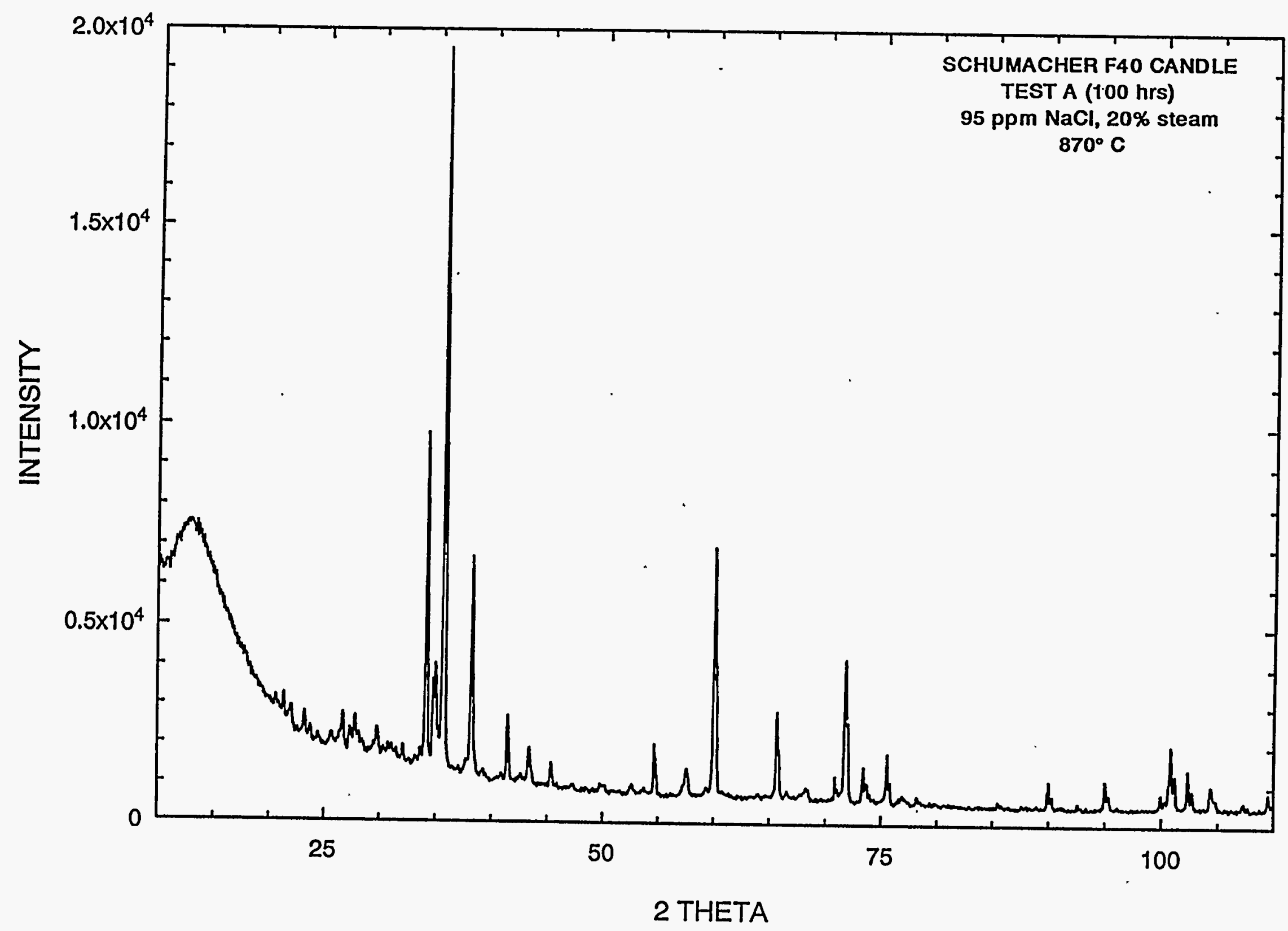




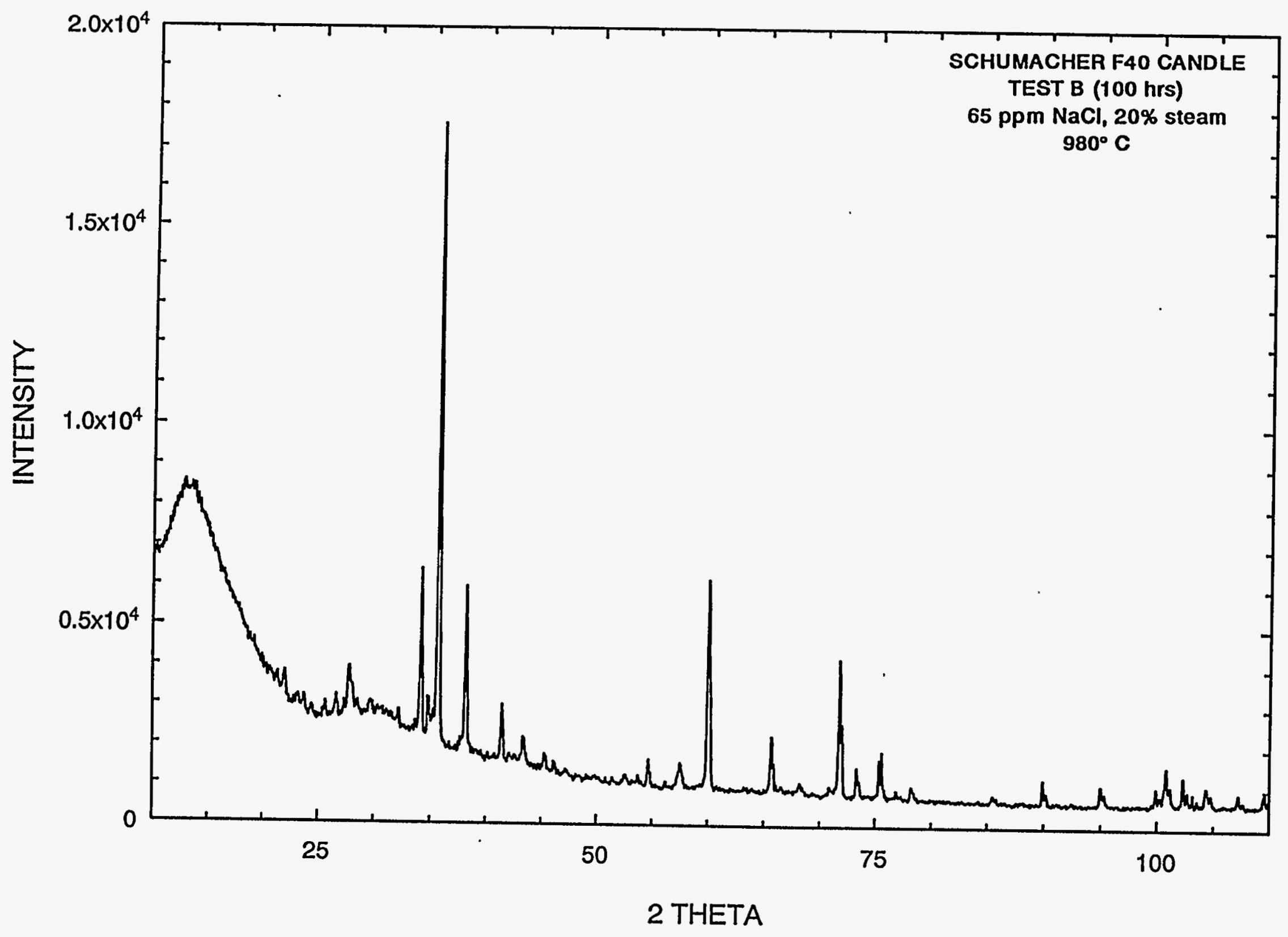




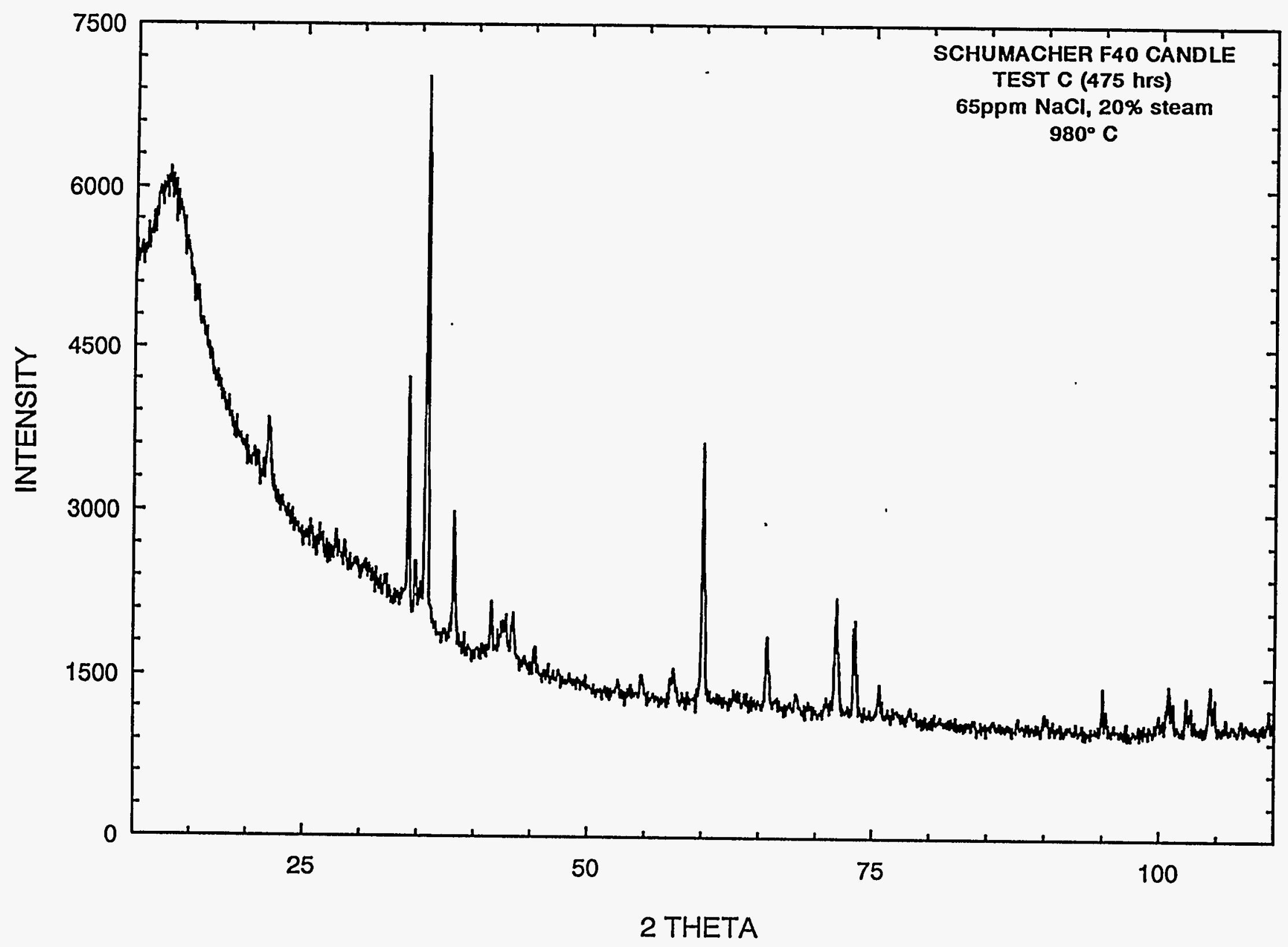




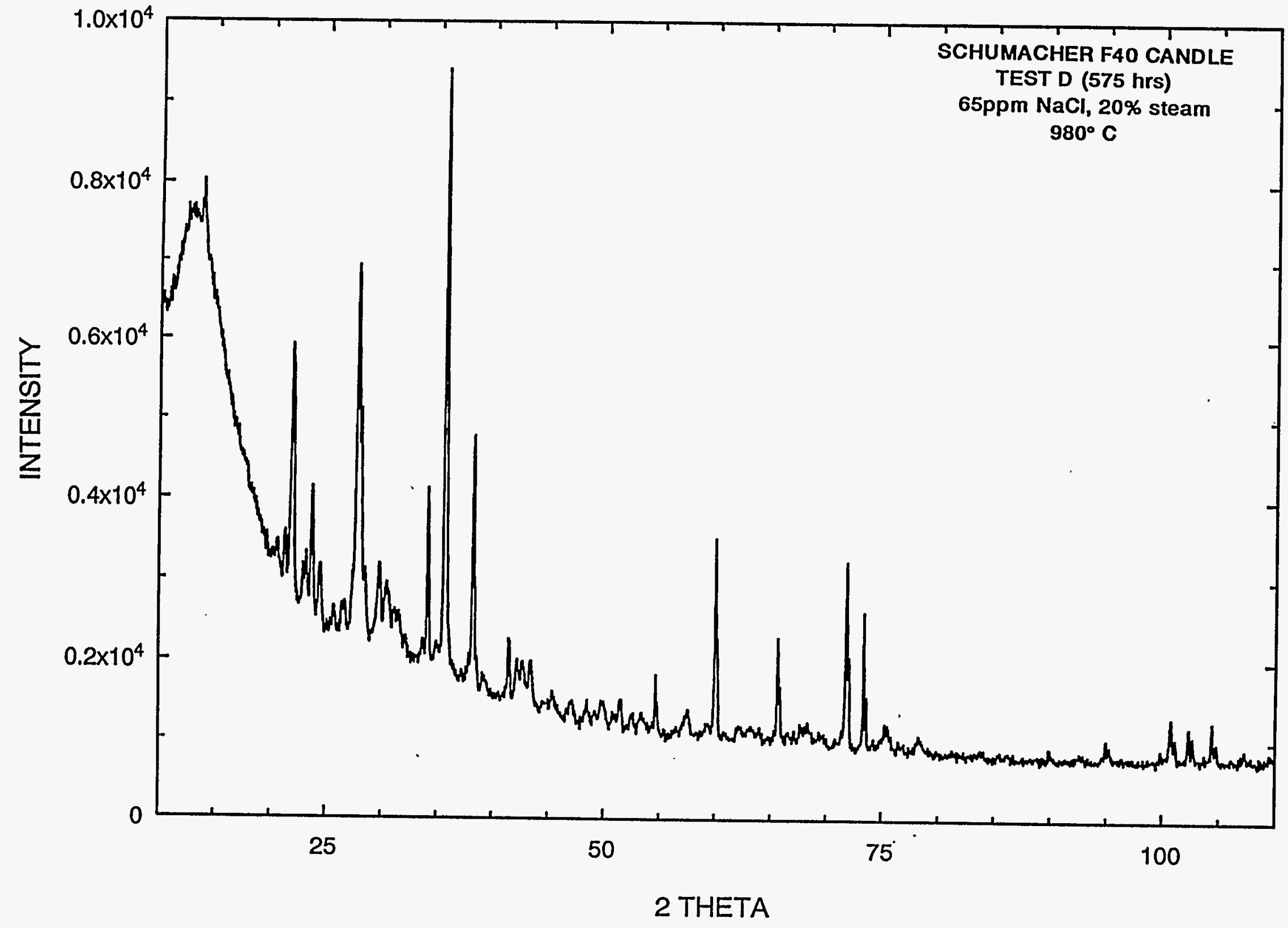




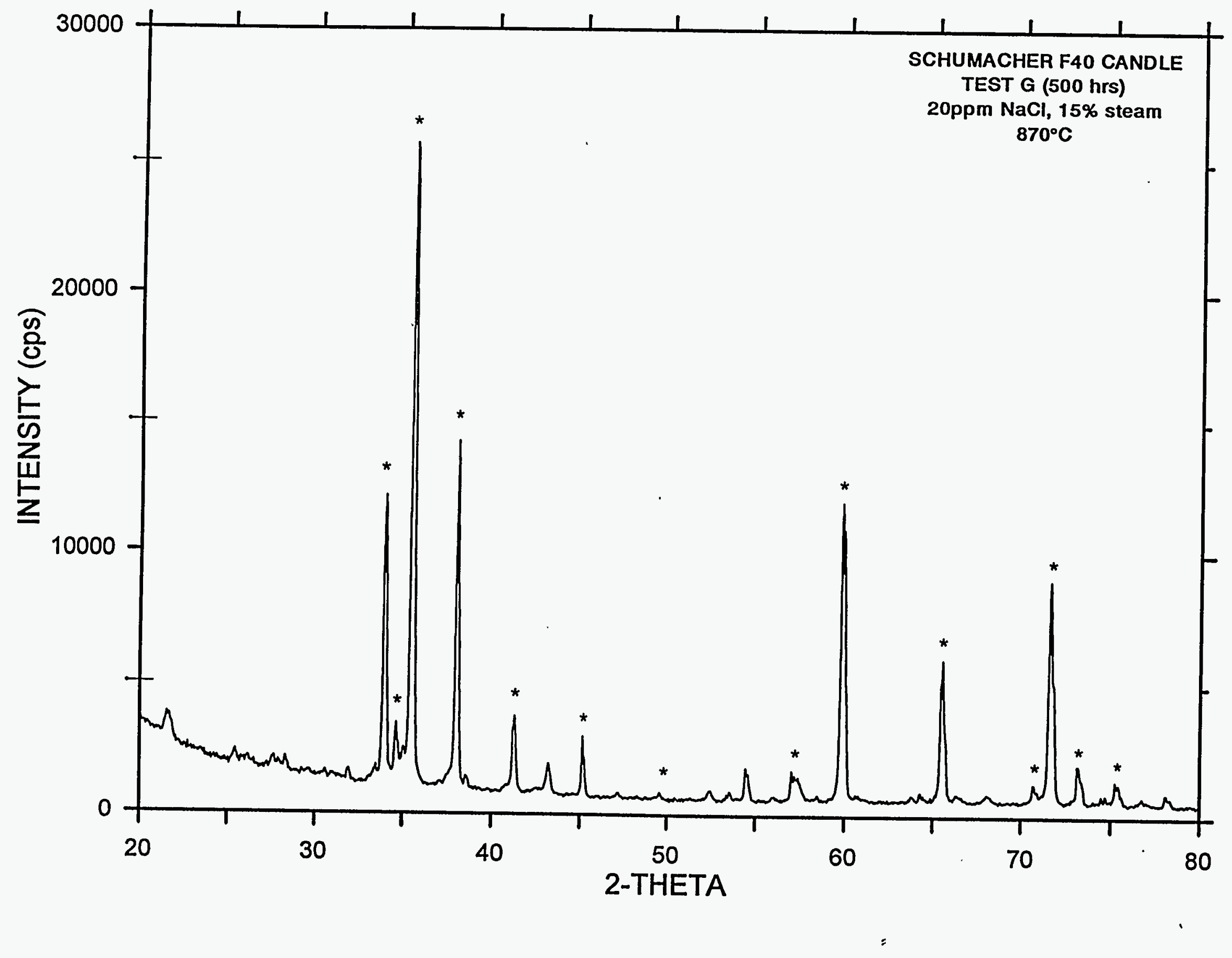




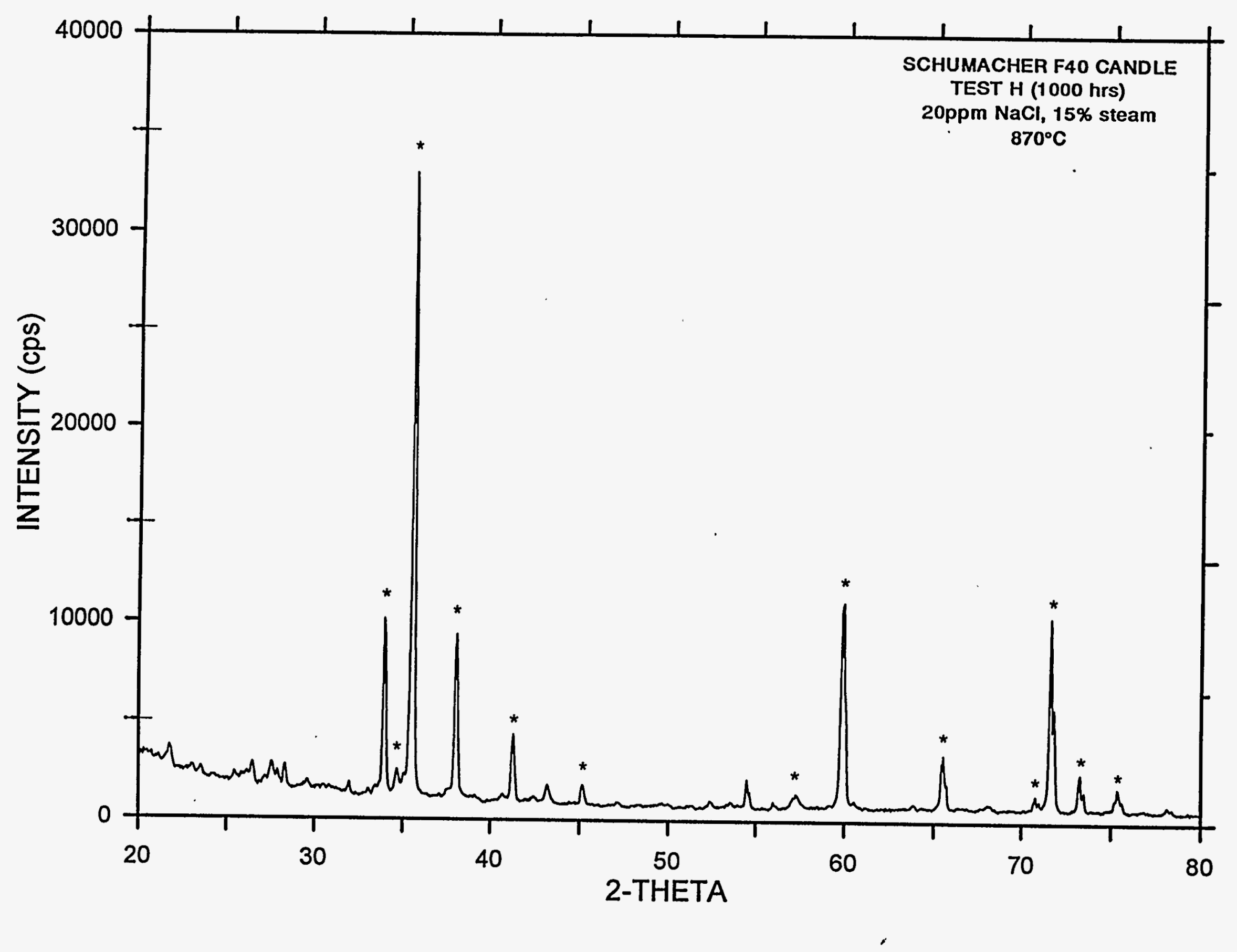




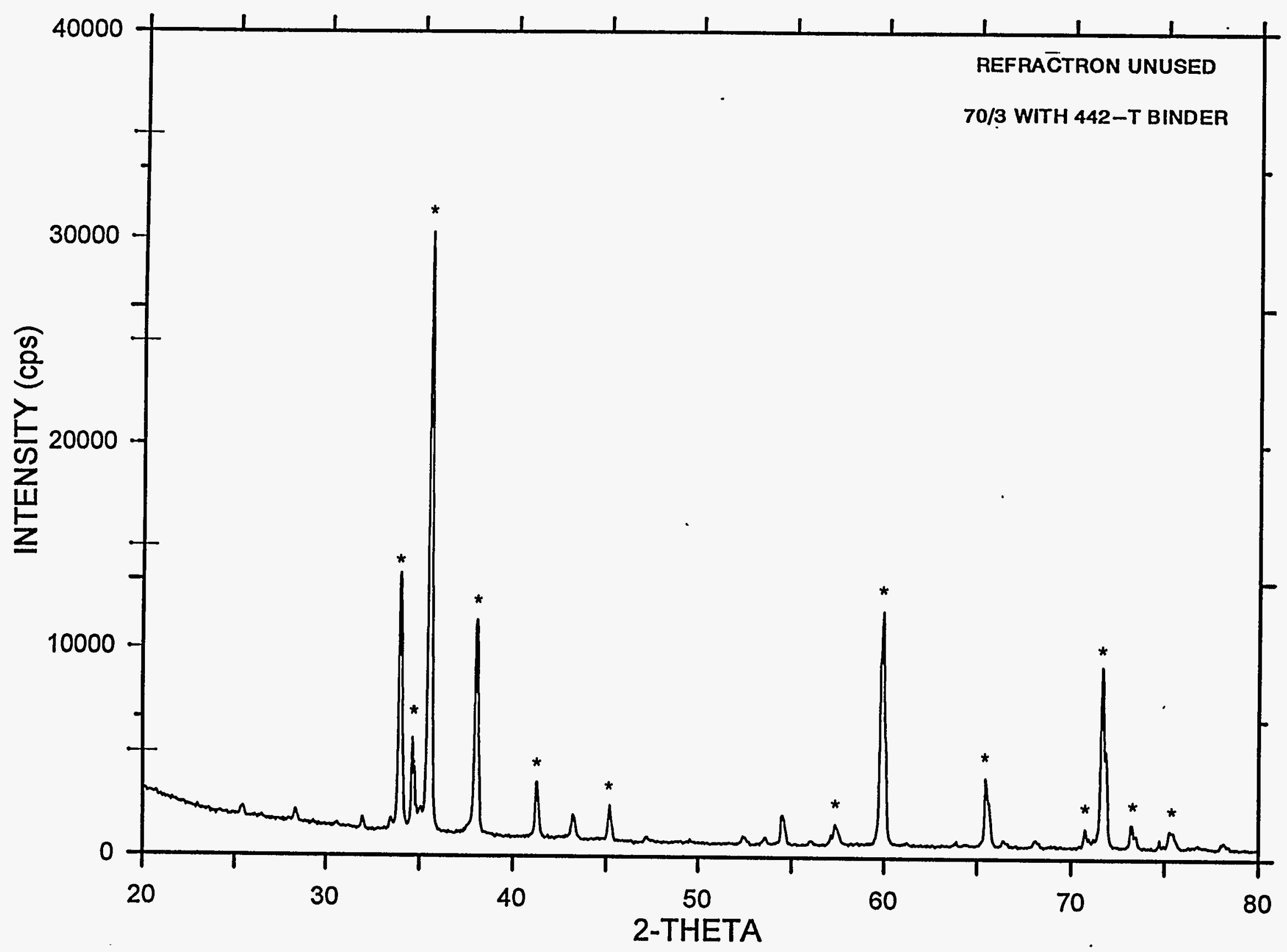




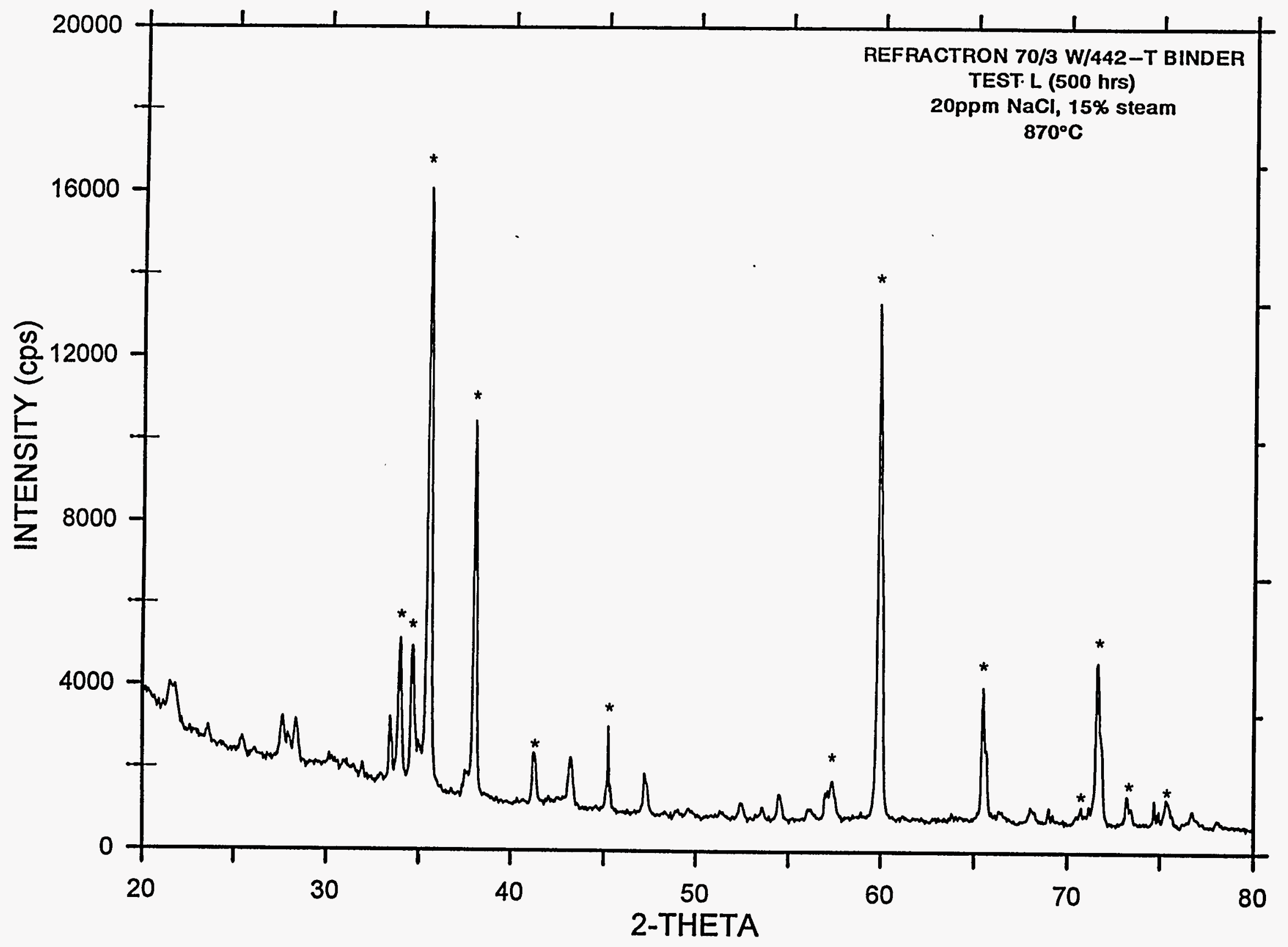




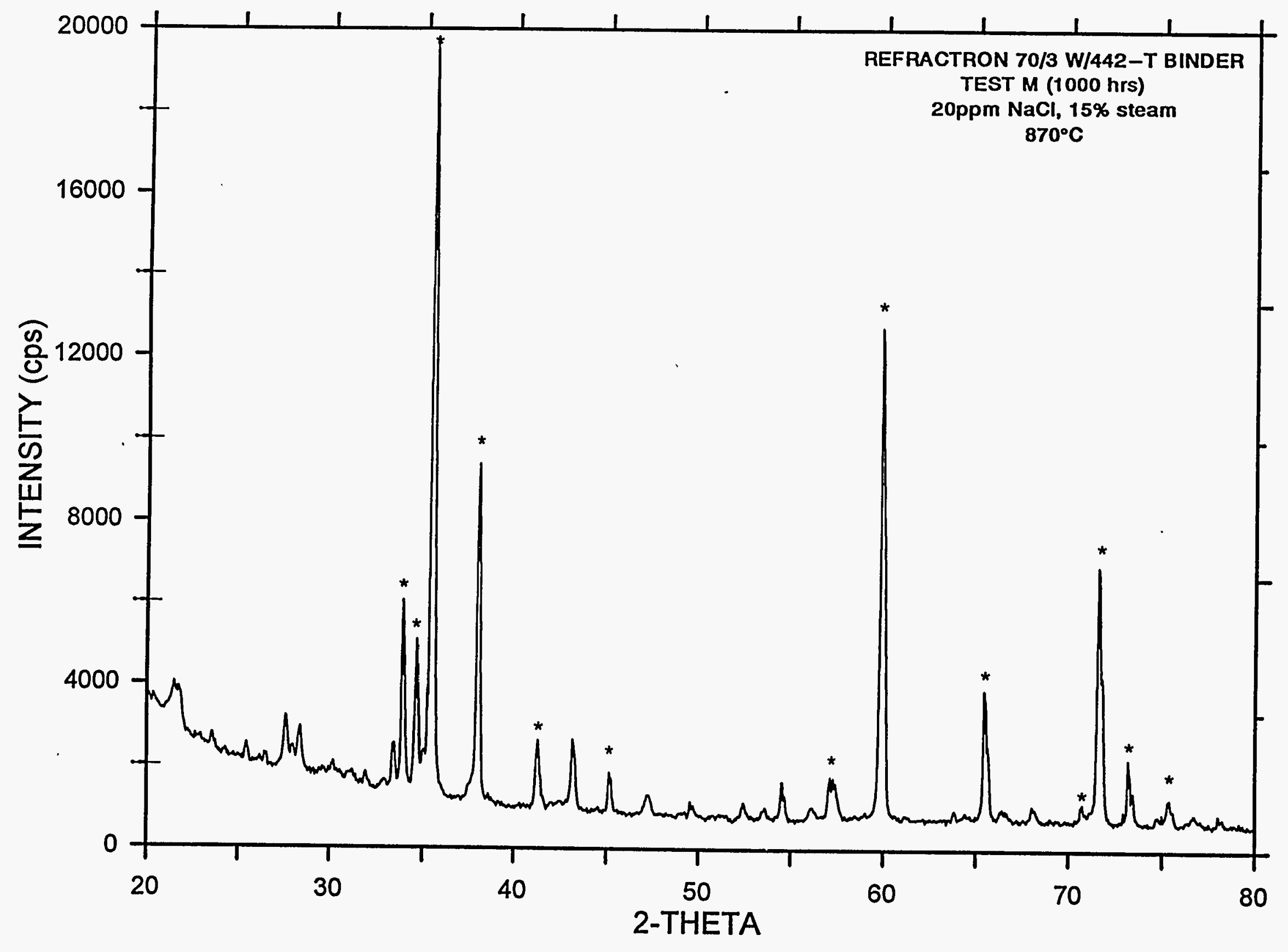




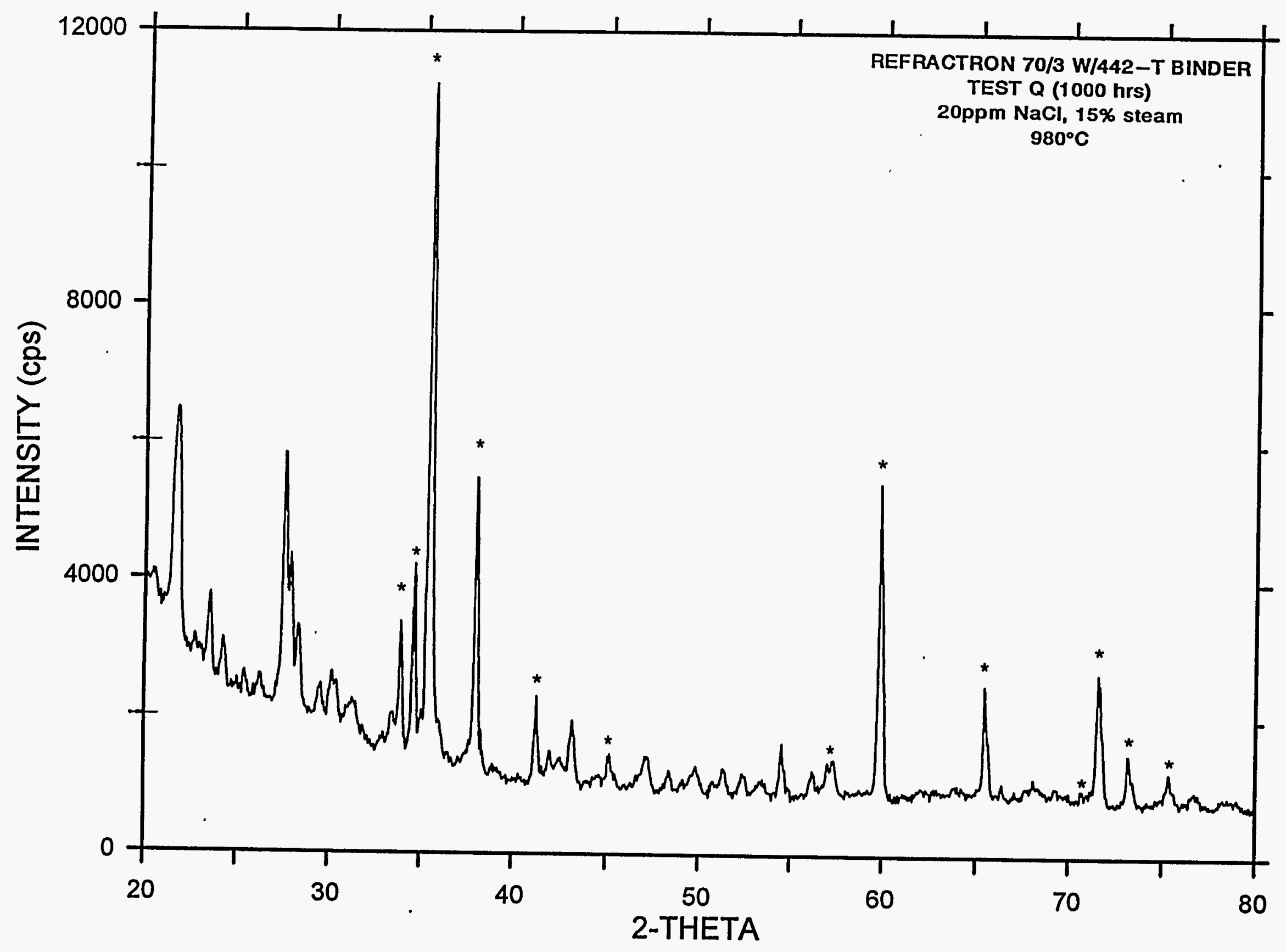




\section{APPENDIX F \\ REPORT: "ANALYSIS OF CANDLE FILTERS FROM THE KRW GASIFIER"}

Remired for sypaste coptein. Or 


\section{APPENDIX G \\ RAW DATA FROM ALUMINA ROD MEASUREMENTS FOR TUBESHEET DEFLECTION DETECTION}


$-322-$

This Page Intentionally Left Blank 

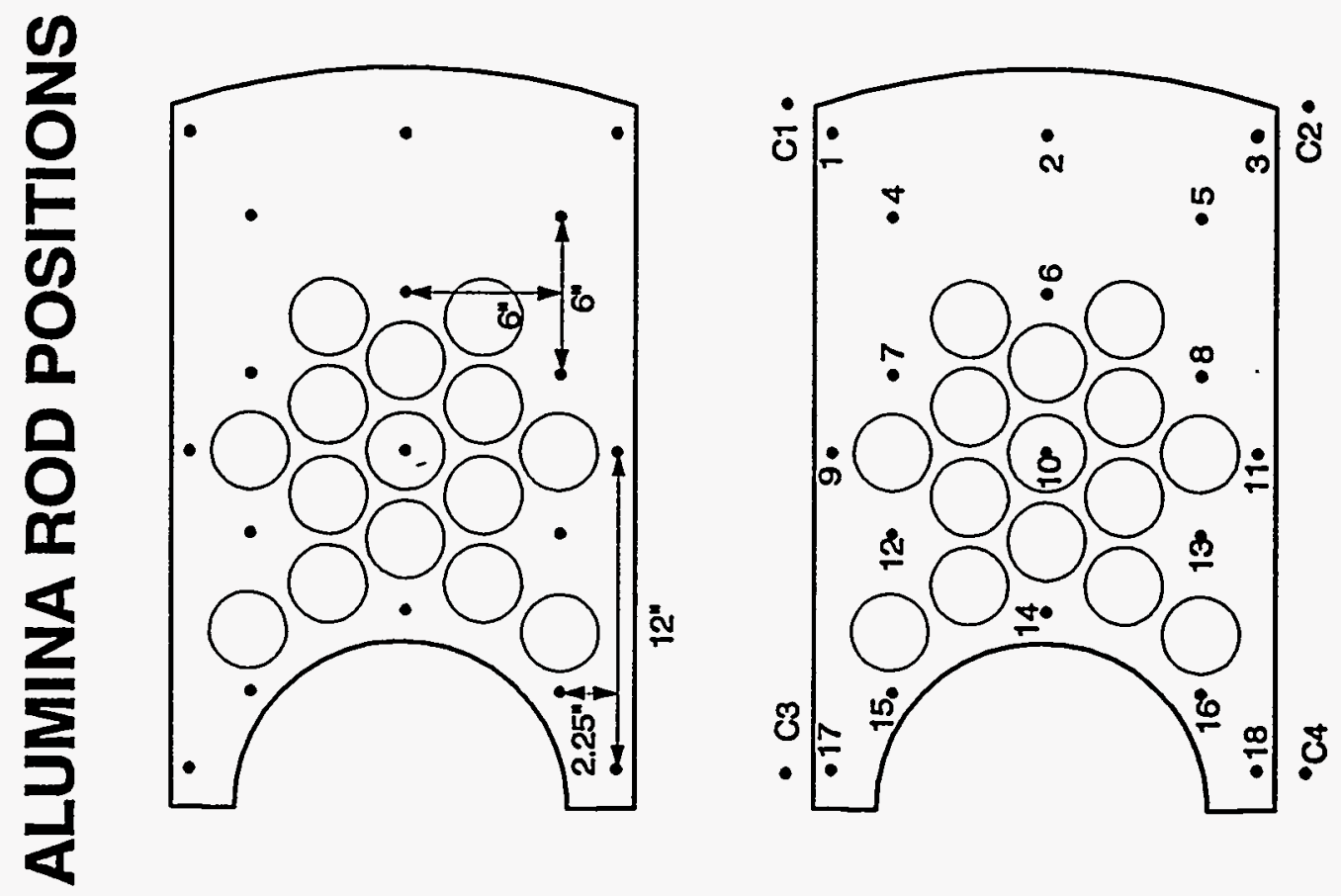
temp $(F)$ or

hours
Raw Alumina Rod Height Measurements (mm)

Alumina rod positions

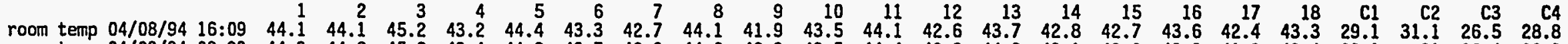

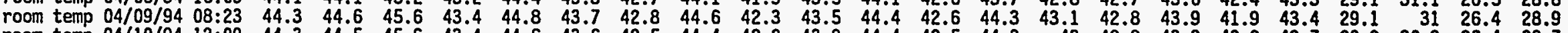
$\begin{array}{llllllllllllllllllll} & 43.3 & 44.4 & 42.5 & 44.3 & 43 & 42.8 & 43.9 & 42.2 & 43.7 & 29.2 & 30.9 & 26.4 & 28.7\end{array}$

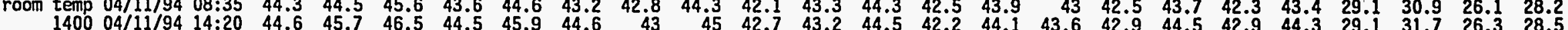

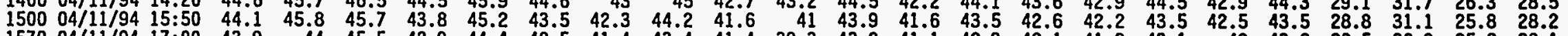

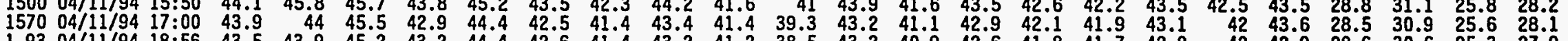

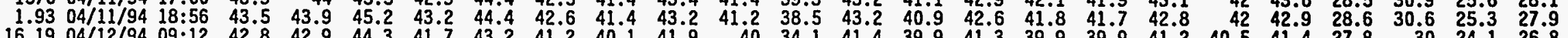

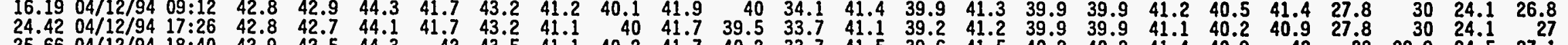

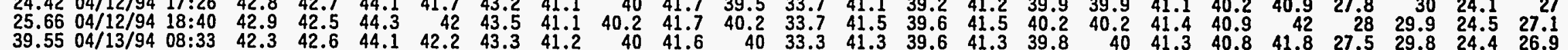

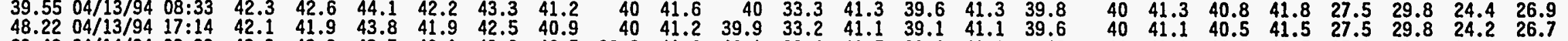

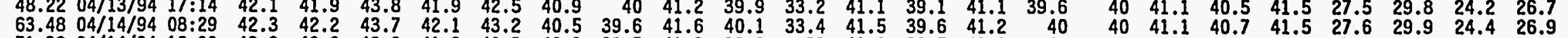

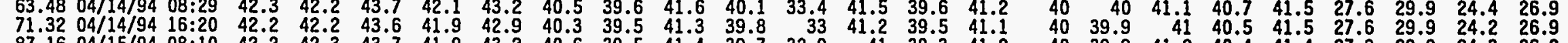

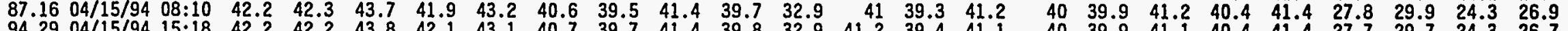

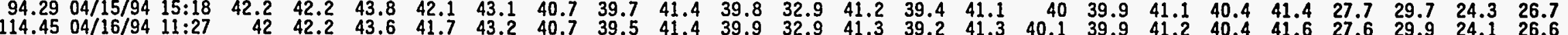

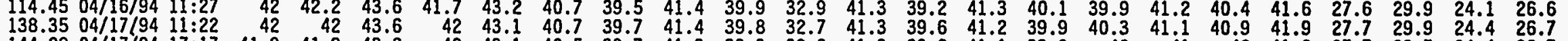

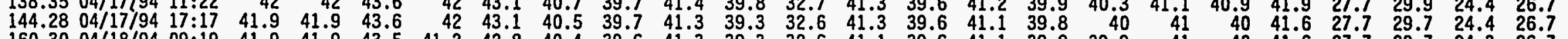

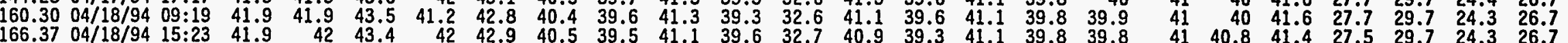

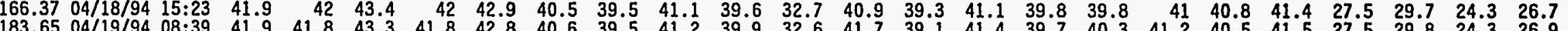

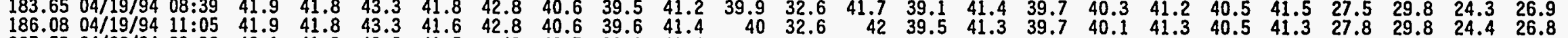

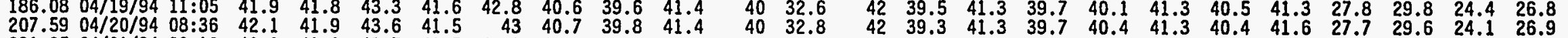

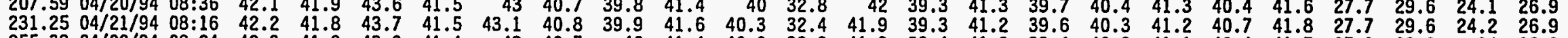

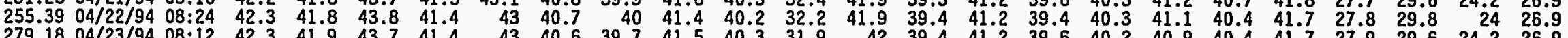

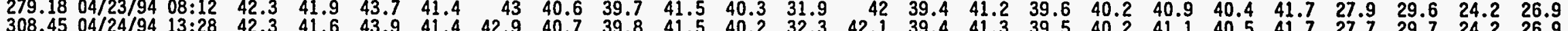

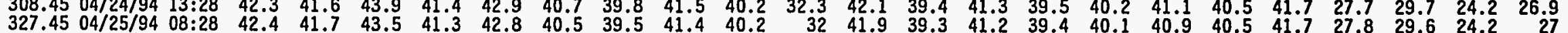

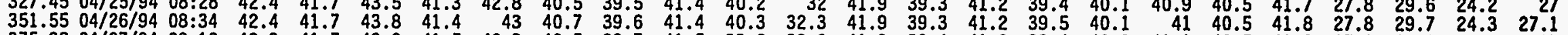

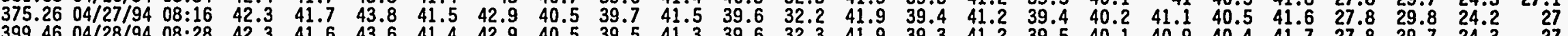

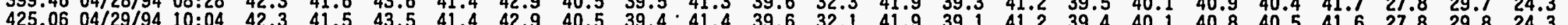

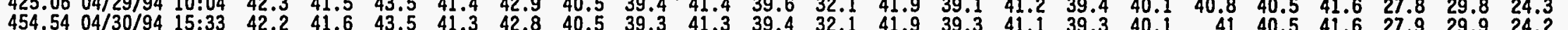

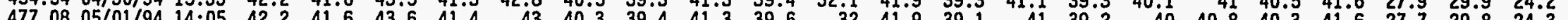

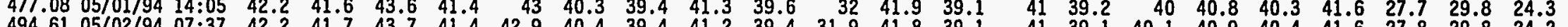

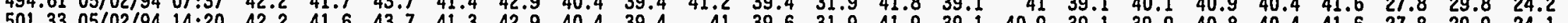

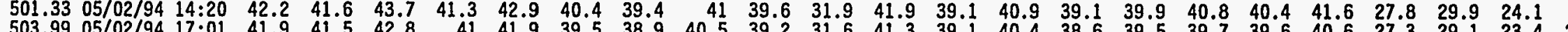

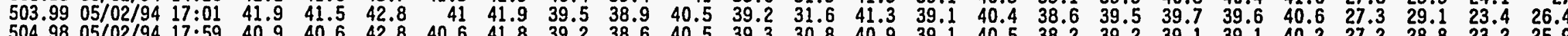

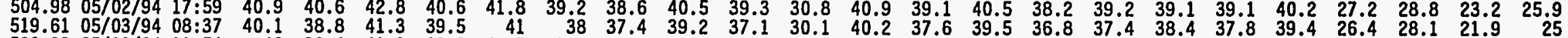

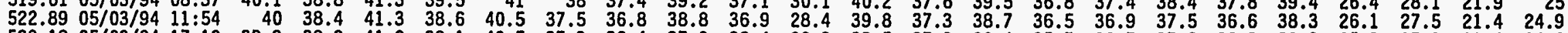

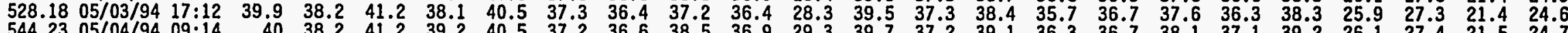

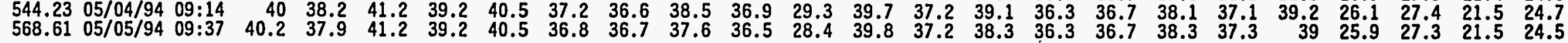


Corrected alumina rod displacement measurements (mm)

measured at $870 \mathrm{C}$

Alumina Rod Positions

elasped

$$
123
$$

hours

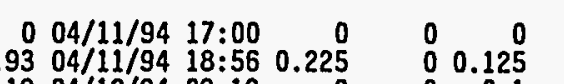

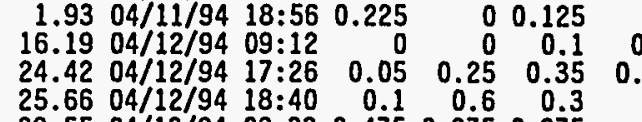
$\begin{array}{llllll}25.66 & 04 / 12 / 94 & 18: 40 & 0.1 & 0.6 & 0.3 \\ 39.55 & 04 / 13 / 94 & 08: 33 & 0.475 & 0.275 & 0.275\end{array}$

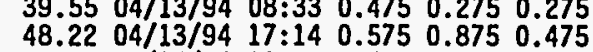

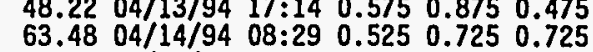
$\begin{array}{lllllll}63.48 & 04 / 14 / 94 & 08: 29 & 0.525 & 0.725 & 0.725 \\ 71.32 & 04 / 14 / 94 & 16: 20 & 0.575 & 0.675 & 0.775\end{array}$ $\begin{array}{lllllll}71.32 & 04 / 14 / 94 & 16: 20 & 0.575 & 0.675 & 0.775 \\ 87.16 & 04 / 15 / 94 & 08: 10 & 0.65 & 0.65 & 0.75\end{array}$ $\begin{array}{llllll}87.16 & 04 / 15 / 94 & 08: 10 & 0.65 & 0.65 & 0.75 \\ 94.29 & 04 / 15 / 94 & 15: 18 & 0.525 & 0.625 & 0.525\end{array}$ $\begin{array}{llllll}94.29 & 04 / 15 / 94 & 15: 18 & 0.525 & 0.625 & 0.525 \\ 114.45 & 04 / 16 / 94 & 11: 27 & 0.675 & 0.575 & 0.675\end{array}$ $\begin{array}{llllll}114.45 & 04 / 16 / 94 & 11: 27 & 0.675 & 0.575 & 0.675 \\ 138.35 & 04 / 17 / 94 & 11: 22 & 0.8 & 0.9 & 0.8\end{array}$

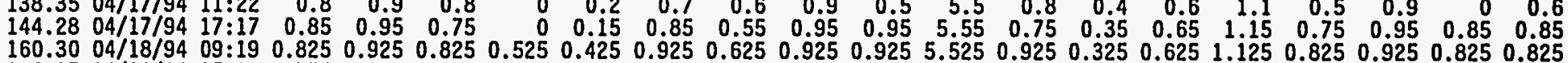

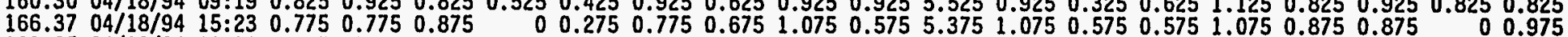

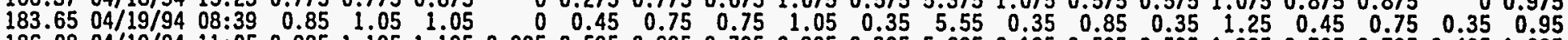

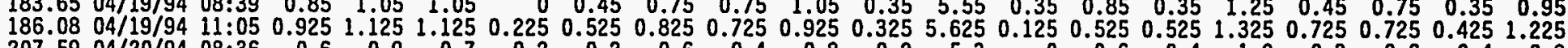

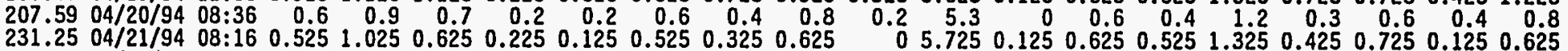

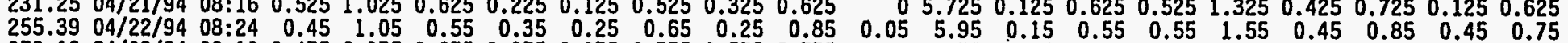

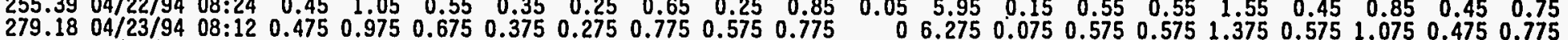

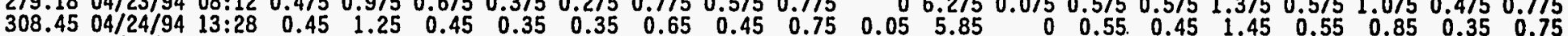

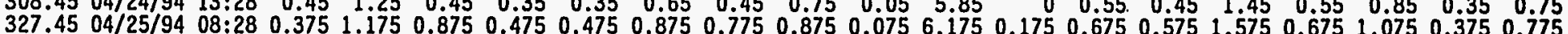

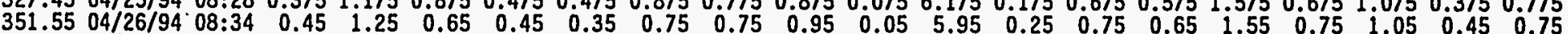

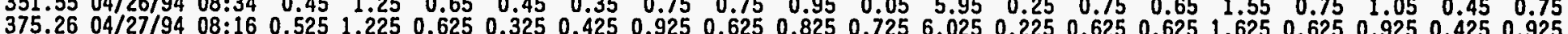

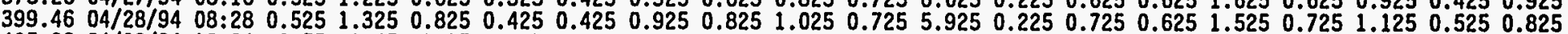

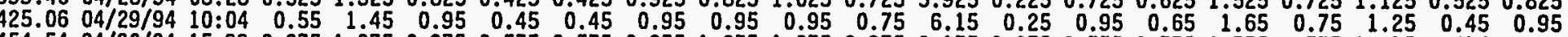
$\begin{array}{lllllllllllllllllllllll}454.54 & 04 / 30 / 94 & 15: 33 & 0.675 & 1.375 & 0.975 & 0.575 & 0.575 & 0.975 & 1.075 & 1.075 & 0.975 & 6.175 & 0.275 & 0.775 & 0.775 & 1.775 & 0.775 & 1.075 & 0.475 & 0.975\end{array}$

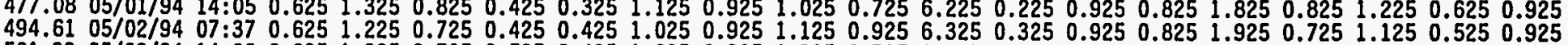

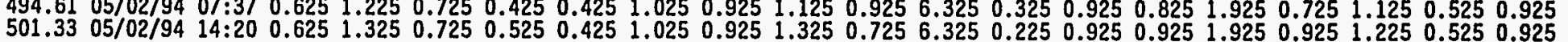

